DEDALUS - Acervo - IEE

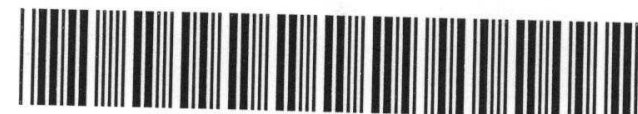

30400001909

ANDRÉ XAVIER LIMA

\title{
ESTUDO DE VIABILIDADE TÉCNICO-ECONÔMICA \\ DE UMA USINA DE INCINERAÇÃO DE RESIDUOS SÓLIDOS URBANOS NO ABCD
}

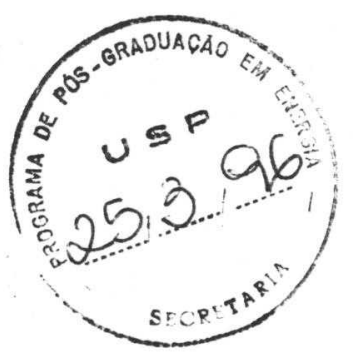

Dissertação apresentada ao Programa Interunidades de Pós-Graduação em Energia (Instituto de Eletrotécnica e Energia/ Escola Politécnica/ Instituto de Física/ Faculdade de Economia e Administração) da Universidade de São Paulo para obtenção do título de Mestre em Energia 
ANDRE XAVIER LIMA

\section{ESTUDO DE VIABILIDADE TÉCNICO-ECONÔMICA DE UMA USINA DE INCINERAÇÃO DE RESIDUOS SOLLIDOS URBANOS NO ABCD}

Dissertação apresentada ao Programa Interunidade de Pós-Graduação em Energia (IEE/EP/IF/FEA) para obtenção do título de Mestre em Energia

Orientador:

Prof. Dr. Roberto Y. Hukai

São Paulo

1994 
Se partires um dia rumo a İtaca, faz votos de que o caminho seja longo,

Tem todo o tempo Itaca na mente. Estás predestinado a ali chegar. Mas não apresses a viagem nunca. Melhor muitos anos levares de jornada e fundeares na ilha velho enfim, rico de quanto ganhaste no caminho, sem esperar riquezas que Ítaca te desse. Uma bela viagem deu-te İtaca. Sem ela não te ponhas a caminho. Mais do que isso não cumpre dar-te. Ítaca. Konstantinos Kaváfis. 


\section{AGRADECIMENTOS}

A todos os amigos pelo incentivo constante

Ao Consórcio Intermunicipal Grande $A B C$ na pessoa de sua coordenadora Alzira S. Nishikubo pelo acesso a informações preciosas para a realização deste trabalho À Fundação de Amparo à Pesquisa do Estado de São Paulo (FAPESP) pelo suporte
financeiro fornecido através de bolsa de estudos 


\section{SUMÁRIO}

Lista de Tabelas

Lista de Figuras

Resumo

Abstract

1 Introdução.

1.1 Aspectos Gerais

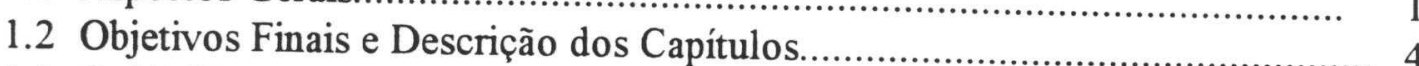

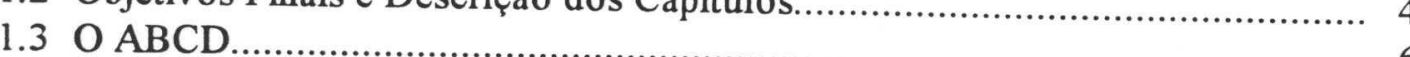

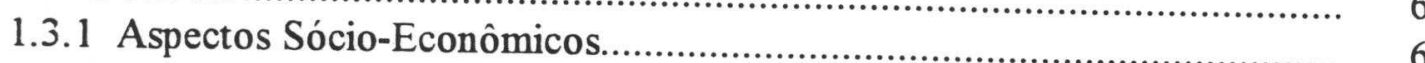

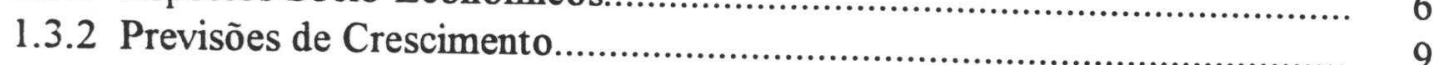

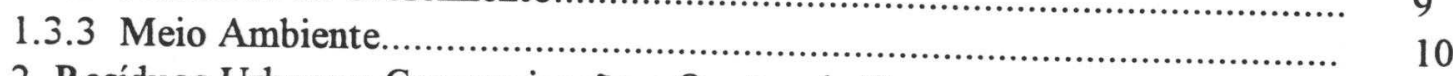

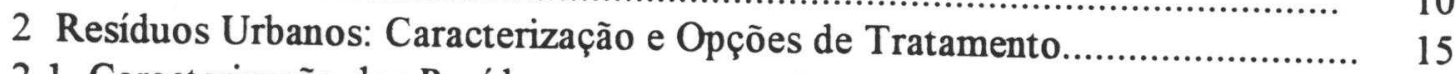

2.1 Caracterização dos Resíduos.................................................................. 16

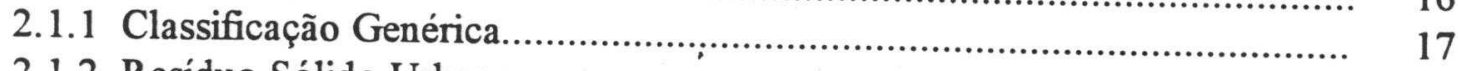

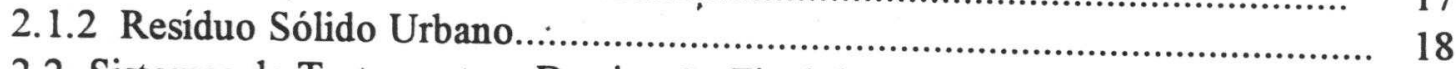

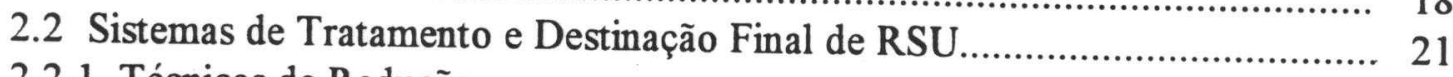

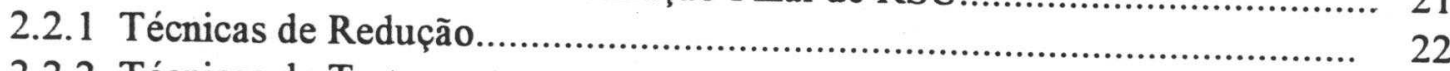

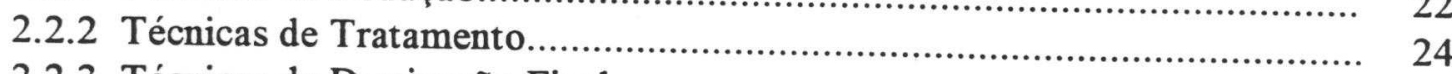

2.2.3 Técnicas de Destinação Final................................................................... 25

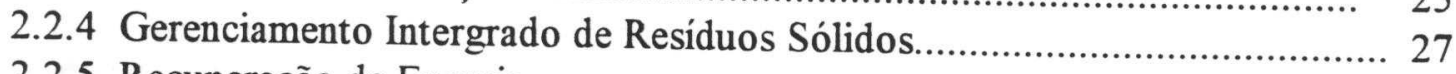

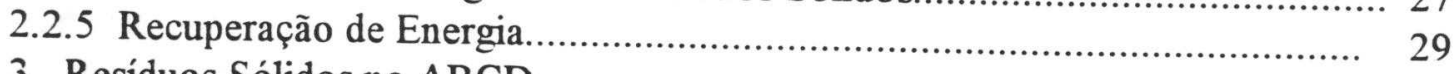

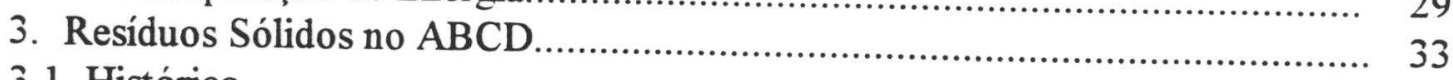

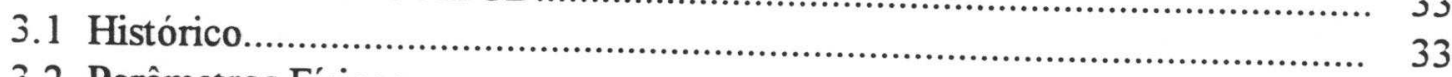

3.2 Parâmetros Físicos.......................................................................... $\quad 38$

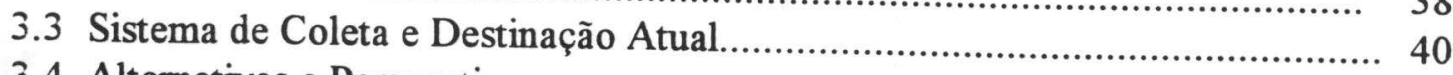

3.4 Alternativas e Perspectivas...................................................................... 44

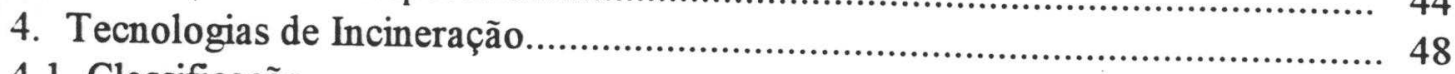

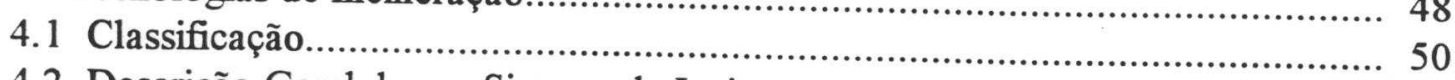

4.2 Descrição Geral de um Sistema de Incineração................................................. 55

4.3 Sistemas de Grelhas Mecânicas............................................................. 57

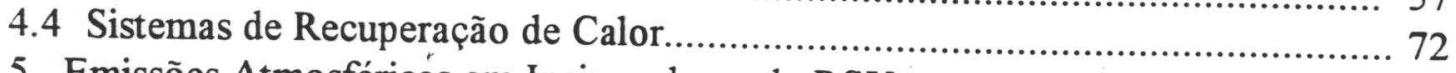

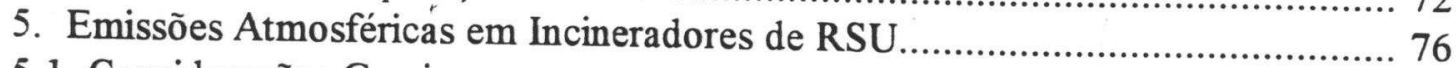

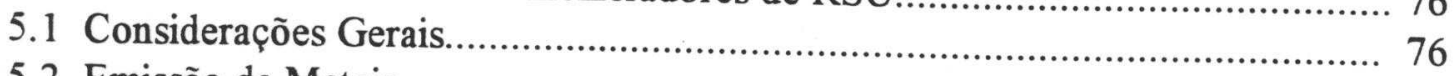

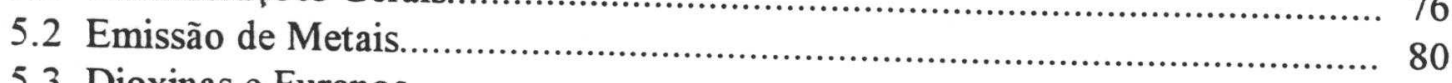

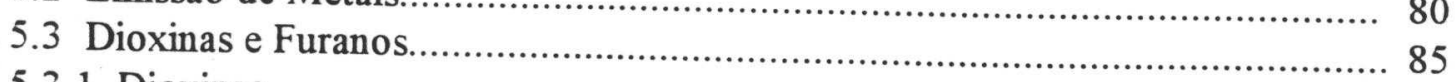

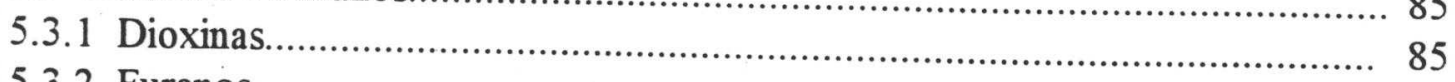

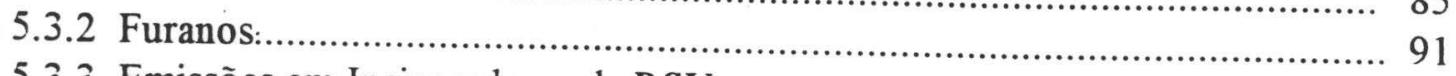

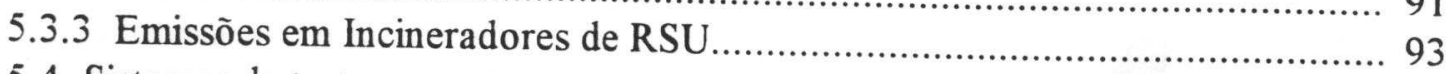

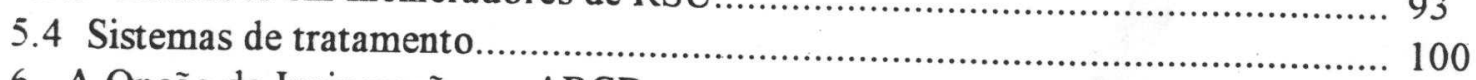

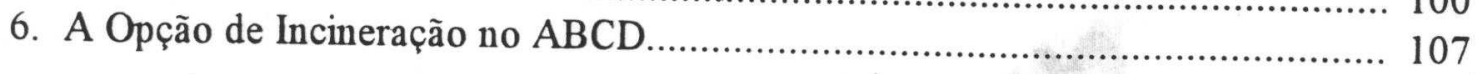


6.1 Aspectos Gerais.

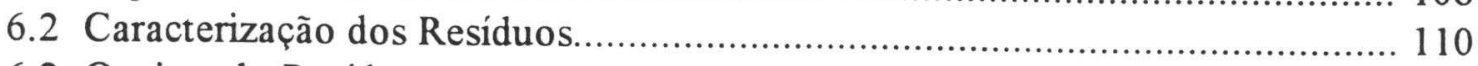

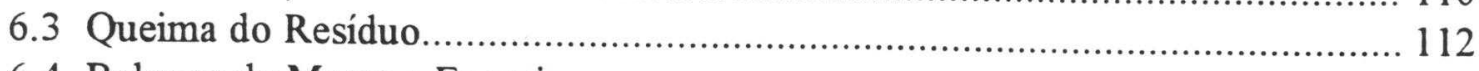

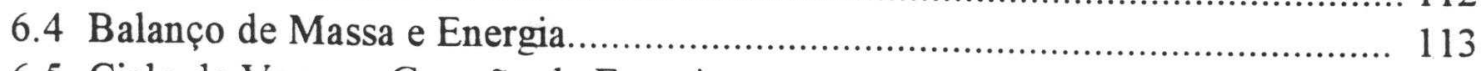

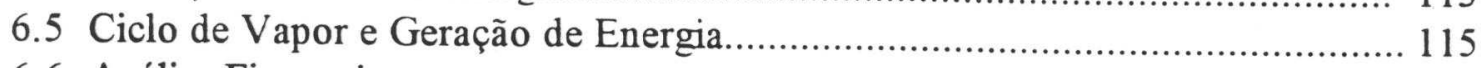

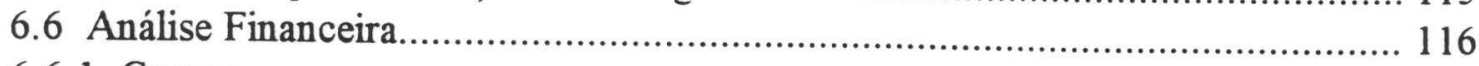

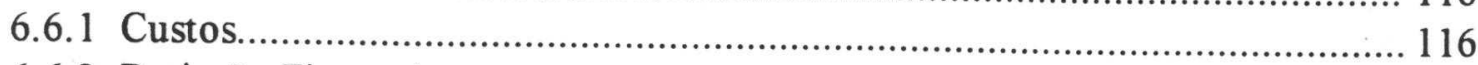

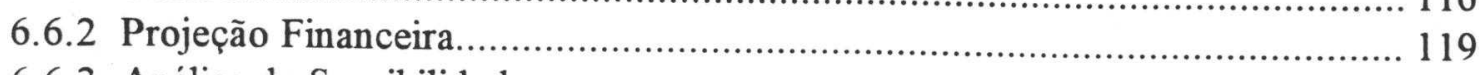

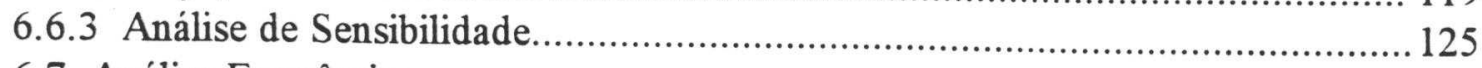

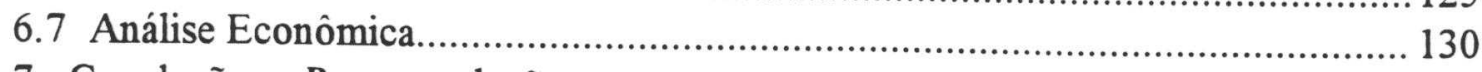

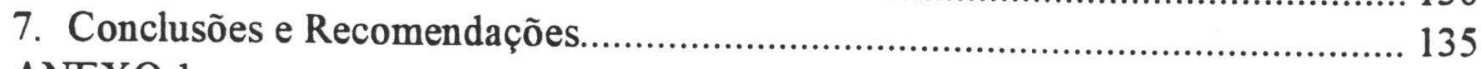

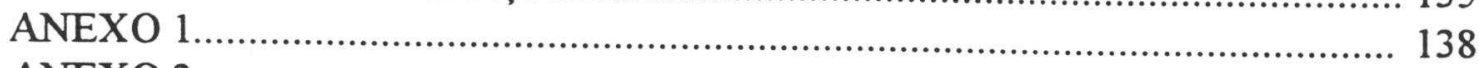

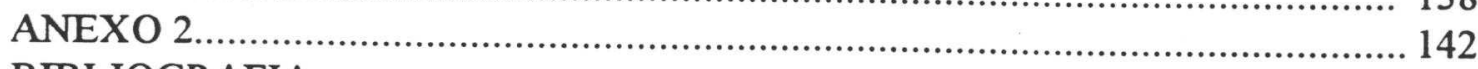

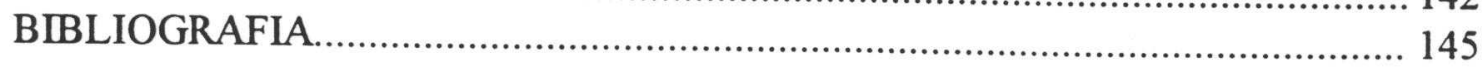




\section{Lista de Tabelas}

Tabela 1.1 - População Residente por Situação do Domicilio

Tabela 1.2 - Dados gerais sobre a Região do $\mathrm{ABCD}$

Tabela 1.3 - Crescimento Populacional por Município e Situação do Domicilio, 70-80, 80-91, 70-91 (em \% a.a.)

Tabela 1.4 - População residente no ABCD: 1991 e estimativas para 2010

Tabela 1.5 - Classificação das Áreas dos Municípios segundo a Lei de Proteção dos Mananciais, 1992

Tabela 2.1- Composição fisica média do Lixo Urbano de diversas cidades

Tabela 3.1- Coleta de domiciliar de Resíduos Sólidos (1991), segundo EMPLASA 39

Tabela 3.2 - Atendimento dos serviços de Limpeza Urbana e coleta potencial no ABC.39

Tabela 3.3 - Parâmetros físico-químicos do RSU na região do ABCD 40

Tabela 3.4 - Serviços de Limpeza Pública no ABCD e Executores 41

Tabela 3.5 Custos e Arrecadação dos Serviços de Limpeza pública no ABCD. 41

Tabela 3.6 - Soluções Adotadas e Características das Áreas de Destinação Final na Região Sudeste da RMSP (1991)

Tabela 3.7 - Características de Áreas de Interesse para Destinação de RSU no ABCD 46

Tabela 4.1- Inicineração de Resíduos: Penetração em países selecionados

Tabela 4.2 - Principais empresas fabricantes de usinas de incineração de RSU no mundo

Tabela 4.3 - Comparação entre usinas com e sem recuperação de calor

Tabela 5.1 - Padrões de Emissões na Europa para Incineradores

Tabela 5.2 - Limites de emissões determinados pela RES CONAMA 03 de $28 / 06 / 1990$

Tabela 5.3 - Faixas de emissão de poluentes pela queima de RSU

Tabela 5.4 - Concentração de Cádmio e Chumbo nos Resíduos de Incineração

Tabela 5.5 - Contribuição de materiais para o cádmio e chumbo presentes na parcela combustivel do RSU.

Tabela 5.6 -Concentração de dioxina detectada como impureza em produtos químicos 86 
Tabela 5.8 - Meia Vida das Dioxinas em diversos meios 90

Tabela 5.9 - Concentrações de Dioxinas medidas em incineradores 93

Tabela 5.10 - Limites para emissões de dioxinas em 2,3,7,8 equivalente 99

Tabela 5.11 - Comparação de concentração de poluentes no gás bruto e limites de emissão

Tabela 6.1 - Previsões das quantidades de RSU nos municípios do ABCD em 2010108

Tabela 6.2 - Efeito de programas de Reciclagem sobre a quantidade de RSU $\quad 109$

Tabela 6.3 - Composição média do Resíduo a ser Incinerado

Tabela 6.4 - Composição volumétrica na exaustão considerando $50 \%$ de excesso de ar

Tabela 6.5 - Balanço de Massa

$\begin{array}{ll}\text { Tabela } 6.6 \text { - Balanço de Energia } & 114\end{array}$

Tabela 6.7 - Investimentos para usina de incineração de 1200 tpd 119

$\begin{array}{ll}\text { Tabela } 6.8 \text { - Condições do financiamento } & 120\end{array}$

Tabela 6.9 - Cronograma de desembolsos durante a implantação 120

$\begin{array}{ll}\text { Tabela 6.10 - Planilha do Financiamento } & 120\end{array}$

Tabela 6.11 - Taxa de Incineração (US\$/t) em função da taxa de desconto e preço de

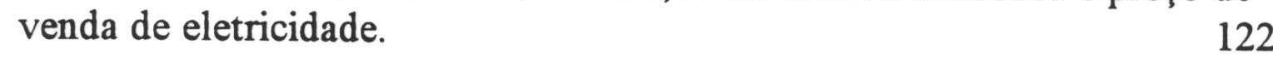

Tabela 6.12 - Critérios de depreciação dos investimentos 123

Tabela 6.13 - Projeções de Resultado $\quad 124$

Tabela 6.14 - Quadro de Fontes e Usos de Recursos $\quad 124$

Tabela 6.15 - Planilha de Projeção do Fluxo de Caixa 124

Tabela 6.16 - Custos e Beneficios de uma usina de incineração de RSU 133

Tabela 6.17 - Matriz de ordenamento de resultados ILPES 133 


\section{Lista de Figuras}

Figura 1.1- RMSP: Restrições do Meio Físico

Figura 1.2 - RMSP: Restrições Legais

Figura 1.3 - RMSP: Restrições demográficas - A mancha urbana

Figura 2.1 - Resíduos Sólidos - Classificação

Figura 2.2 - Técnicas de Gerenciamento de RSU

Figura 2.3 - Estágios do ciclo de vida de um produto

Figura 2.4 - Uso de energia em função da fração reciclada.

Figura 2.5 - Efeito de programas de reciclagem sobre o poder calorífico do lixo

Figura 4.2 - Caldeira e combustor de Leito Fluidizado Circulante mostrando-se os gases de exaustão alimentando a caldeira

Figura 4.3 - Esquema típico de uma usina de incineração de resíduos sólidos

Figura 4.4 - Seção Longitudinal de uma usina de incineração

Figura 4.5 - Processo de queima em incinerador de câmara simples e grelha inclinada 59

Figura 4.6 - Grelha de movimento saltante [fonte: Brunner, 1991] 60

Figura 4.7 - Esquema típico de grelha de movimento alternativo linear 60

Figura 4.8 - Esquema de um forno rotatório

Figura 4.9 - Fornalha e grelha do Sistema Martin

Figura 4.10 - Sistema Von Roll

Figura 4.11- Sistema VKW (Grelha DBA)

Figura 4.12 - Grelha rolante DBA

Figura 4.13 Sistema Alberti

Figura 4.14 Sistema Esslingen

Figura 4.15 - Sistema Herman Nichol 
Figura 4.17 - Sistema Volund

Figura 4.18 - Grelha ABB

Figura 4.19 - Sistema Westinghouse O'Connor

Figura 4.20 - Três configurações de caldeiras de recuperação

Figura 5.1- Destino ambiental e toxicológico de um produto químico

Figura 5.2 - Repartição dos metais entre os produtos de combustão em função da temperatura de ebulição.

Figura 5.3 - Valores médios de repartição de metais entre os produtos de combustão. 83

Figura 5.4 - Representação das dioxinas e fórmula mínima da TCDD.

Figura 5.5 - Representação de Furanos e fórmula mínima dos TCDF

Figura 5.6 - Curva teórica de formação e destruição de clorofenóis.

Figura5.7 - Curva de decomposição térmica para uma mistura de três compostos perigosos.(log Fração restante (\%) x temperatura C)

Figura 5.8 - Curva de decomposição térmica

Figura 5.9 - Dependência da emissão de PCDD na emissão de material particulado 98

Figura 5.10 -Emissões totais de PCDD/PCDF como função da concentração de CO, ambos medidos na saída do precipitador eletrostático do incinerador de Quebec City.

Figura 5.11 - Sistema de tratamento de gases com processo "filsorption"

Figura 5.12 - Estágio "filsorption" para controle de dioxinas e furanos

Figura 5.13 - Processo DEGLOR para descontaminação, vitrificação e recuperação de metais das cinzas de filtros.

Figura 6.1 - Ciclo de Rankine calculado para a usina do ABCD

Figura 6.2 - Custos de Capital de Usinas de RSU

Figura 6.3 - Custos específicos (1993 US\$/tpd) para usinas de RSU

Figura 6.4 - Taxa de incineração em função da taxa de desconto e preço de venda de eletricidade

Figura 6.5 - Taxa de incineração em função do custo de capital da usina e taxa de desconto 
Figura 6.6 - Taxa de incineração, poder calorífico inferior do resíduo e rendimento da usina

Figura 6.7 - Sensibilidade da taxa de incineração

Figura 6.8 - Taxa interna de retorno como função do preço da eletricidade e tx. de desconto

Figura 6.9 - Taxa interna de retorno vs. taxa nominal do financiamento

Figura 6.10 - TIR do empreendimento vs. composição do investimento e tx. nominal do financiamento

Figura 6.11 - TIR do capital próprio vs composição do investimento e tx. nominal do financiamento 


\section{Resumo}

A incineração de resíduos sólidos urbanos tem sido cogitada como solução para problemas relacionados com a destinação final dos resíduos gerados em regiões metropolitanas.

Este trabalho revê a situação dos resíduos sólidos na sub-região sudeste da Região Metropolitana de São Paulo e analisa a viabilidade de uma usina de incineração com geração de energia elétrica para tratamento dos resíduos sólidos coletados na região.

É realizada uma revisão das tecnologias existentes e da emissão de poluentes atmosféricos, inclusive dioxinas e furanos, por incineradores de grande porte. Apesar de não ser atrativa financeiramente para as taxas de desconto usuais e as atuais taxas de tratamento e disposição final praticadas, a alternativa da incineração oferece diversas vantagens que devem ser analisadas em estudos comparativos aprofundados com as demais opções para a disposição de resíduos sólidos da Região Metropolitana de São Paulo. 


\begin{abstract}
MSW incineration has been considered a solution to the problems related to final disposal of waste generated in metropolitan regions.

This work reviews the situation of MSW in the southeastern region of the Metropolitan Area of São Paulo and analyses the viability of an incineration plant with electric power generation for the treatement of MSW colected in that region. Existing technologies are reviewed alongside with the emission of atmospheric pollutants, including dioxins and furans, for large scale incineration plants.

Besides not being financially attractive with market discont rates and present treatement and final deposition taxes collected, the alternative of MSW incineration presents several advantages that deserve being assessed in detail on a comparative basis with other options for disposal of MSW in the Metropolitan Region of São Paulo.
\end{abstract}




\section{Capítulo 1 \\ Introdução}

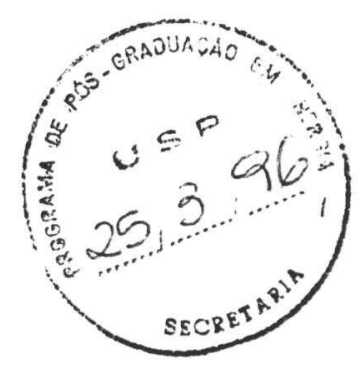

\subsection{Aspectos Gerais}

$O$ processo de industrialização brasileira no pós-guerra foi marcado pelo desenvolvimento urbano-industrial tendo o eixo Rio - São Paulo como área privilegiada para a sua realização. Este processo caracterizou-se, entre outros fatores, pela intensa metropolização de São Paulo e do Rio de Janeiro, afirmando-se como polos de desenvolvimento industrial. Assim. nas últimas quatro décadas, ocorreu uma forte corrente migratória em direção a estas metrópoles, em especial à Região Metropolitana de São Paulo.

O crescimento acelerado das regiões metropolitanas trouxe consigo sérios problemas de infraestrutura urbana. Um destes é a grande quantidade de resíduos gerados pela alta concentração humana, o que determinou a necessidade de se implantar processos modernos de tratamento e destinação final dos resíduos. Dentre os residuos gerados, destacam-se o esgoto doméstico e os resíduos sólidos urbanos (RSU). Os esgotos são os resíduos aquosos coletados em rede própria e os resíduos sólidos são todos os resíduos descartados predominantemente no estado sólido. Devido a seu acelerado crescimento, a produção destes resíduos e as soluções empregadas nas regiões metropolitanas sempre estiveram em descompasso, gerando sérios problemas de poluição ambiental e de saúde pública.

O esgoto doméstico quando não adequadamente tratado, torna-se fonte poluidora dos cursos d'água impactando as regiões adjacentes a estes dentro de uma extensão determinada pela capacidade de regeneração natural do meio aquático. Já os RSU, comumente chamados de lixo urbano, tem degradação extremamente lenta e são potenciais poluidores do solo. de águas subterrâneas e do ar quando não corretamente 
acondicionados. Sua disposição não adequada ainda é estimuladora da propagação de vetores de doenças afetando a população circunvizinha do local.

A Região Metropolitana de São Paulo (RMSP) produz diariamente 14 mil toneladas de RSU (1991) sendo que $88 \%$ destes recebem destinação aceitável. Estima-se que a esta quantidade serão adicionados 6 mil toneladas diárias ate 0 ano 2010 implicando em problemas graves de coleta, tratamento e acondicionamento.

A porção sudeste da região metropolitana de São Paulo é conhecida como

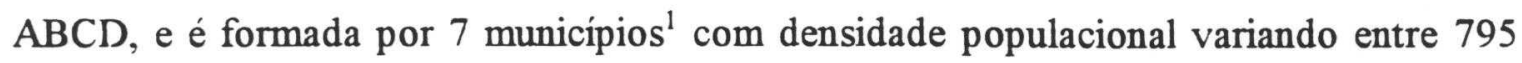
hab/km2 (Ribeirão Pires) a 12.434 hab/km2 (Diadema). Esta região apresenta uma topografia acidentada contribuindo para o adensamento populacional, agravado ainda mais pelo fato de uma parcela significativa da região estar inserida em Área de Proteção aos Mananciais (APM).

Este adensamento populacional gera uma quantidade significativa de RSU. Os serviços oficiais de coleta do lixo, hoje existentes, recolhem 1.232 toneladas por dia de resíduos naquela região. A destinação final dos resíduos tem sido principalmente os aterros sanitários e "lixões". Entretanto, prevê-se que em pouco tempo, estará esgotada a atual capacidade destes depositórios que já atendem a mais de um município. Deve-se ressaltar que parte destes locais de deposição encontram-se dentro de APM, causando grande preocupação quanto aos efeitos ecológicos no meio ambiente local.

Esta problemática tem sido objeto de diversos estudos no passado pelos orgãos competentes do Estado e região metropolitana. Dentre estes destacam-se:

- Estudo da Solução Integrada para a Disposição Final dos Resíduos Sólidos da Sub-região Sudeste da Área Metropolitana da Grande São Paulo realizado pela SERETE Engenharia a pedido do Grupo Executivo da Grande São Paulo (GEGRAN) em 1973;

- Programa Emergencial elaborado pela EMPLASA em conjunto com a CETESB em 1983;

\footnotetext{
${ }^{1}$ Santo Andre. São Bernardo do Campo. São Caetano do Sul. Diadema. Mauá. Ribeirão Pires e Rio Grande da Serra.
} 
- Avaliação da Viabilidade das Alternativas Indicadas (Programa Emergencial), elaborado pelas mesmas empresas em 1988;

- Programa de Intervenções Priorizadas, elaborado pela EMPLASA EM 1990;

- Fundamentos para o Equacionamento da Destinação Final dos Resíduos Sólidos na R.M.S.P. elaborado pela EMPLASA em 1992;

Dentre as alternativas para a solução do problema, existe a possibilidade da criação de aterros sanitários em locais apropriados fora desses municípios onde, comprovadamente, existem mais áreas disponíveis para esta finalidade. Entretanto, esta hipótese implicaria no transporte dos resíduos a grandes distâncias, com pesadas consequências financeiras, além dos distúrbios ambientais associados a esta prática. Essas novas áreas necessitariam ainda de estudo e aprovação pelas autoridades dos respectivos municípios. o que não é tarefa fácil dada a mobilização das comunidades tomadas pela consciência "não em meu quintal" (not in my back yard), bastante comum nestes dias.

A incineração de resíduos sólidos urbanos é uma alternativa bastante utilizada principalmente nos paises industrializados, por ser considerada a "mais limpa" e radical maneira de destruir estes resíduos. As principais vantagens da incineração são:

- Tecnologias comprovadas e comercialmente aceitas;

- Redução do lixo para uma fração $(-10-20 \%)$ do volume total originalmente processado, aumentando a vida útil dos aterros e possibilitando um uso racional do solo urbano;

- Eliminação de odores incovenientes e outros efeitos ecológicos associados aos aterros sanitários:

- Recuperação de parte da energia embutida nos resíduos descartados para geração de eletricidade ou venda de vapor;

Por estas vantagens, a incineração poderá ser uma alternativa válida para o tratamento dos resíduos. A principal delas é a redução do volume aumentando a vida útil 
dos aterrros existentes e adiando a implantação de novos aterros em áreas distantes e, por vezes, fora do próprio município.

A despeito da situação econômica atual, a concentração urbana cada vez maior e o aumento da preocupação ecológica levam a crer que a incineração dos RSU surge também como alternativa válida para áreas de grande adensamento populacional no Brasil como as regiões metropolitanas de São Paulo e Rio de Janeiro, e, mais ainda, para regiões como o $\mathrm{ABCD}$ que tem grande parte de sua área sob proteção ambiental.

A adoção desta alternativa merece um estudo de viabilidade técnica e econômica. Existem vantagens potenciais de fácil comprovação, mas também existem desvantagens na adoção desta alternativa. o que deve ser considerado. Algumas das desvantagens entretanto, dizem respeito a cuidados que devem ser tomados com relação a emissão de efluentes para o ambiente externo. Após décadas de significativas experiências acumuladas, principalmente na Europa, pode-se dizer que a tecnologia de incineração está dominada. Com relação a emissões, houve avanços significativos nos últimos 10 anos, mesmo com relação a emissão de dioxinas e furanos ${ }^{2}$ que se tornaram alvo de muita controvérsia no início dos anos 80 .

O objeto deste estudo é a análise da da viabilidade técnica e econômica da opção de se incinerar o lixo sólido urbano, opção esta que, pelas vantagens apresentadas acima, deverá se tornar inevitavelmente em um dos principais focos de atenção da sociedade e das autoridades do $\mathrm{ABCD}$ e municipios circunvizinhos.

\section{2- Objetivos Finais e Descrição dos Capítulos}

Esta dissertação tem por finalidade a elaboração de um estudo de préviabilidade técnico-econômica de uma usina de geração elétrica acionada pela queima de resíduos sólidos urbanos. a ser localizada na região do $\mathrm{ABCD}$.

A dissertação possui os seguintes objetivos específicos:

\footnotetext{
${ }^{2}$ Compostos químicos, extremamente cancerígenos. formados na queima de plásticos rígidos e outros materiais organo-clorados.
} 
1) Avaliação do estado da arte da tecnologia de incineração de resíduos sólidos urbanos:

2) Levantamento da situação atual e previsões da destinação do lixo urbano no ABCD;

3) Determinação do preço de incineração por tonelada de lixo queimada a ser pago pelas prefeituras, em função da tarifa de venda da eletricidade, para viabilizar o empreendimento a partir de dados de custos de uma usina referencial escolhida;

Para atingir estes objetivos, organizou-se esta dissertação em 7 capítulos. No próximo item deste capítulo 1 realiza-se uma descrição do ambiente socio-econômico da região em estudo. No segundo capítulo realiza-se uma caracterização do lixo e uma revisão das técnicas disponíveis de gerenciamento de resíduos sólidos urbanos. No terceiro capitulo apresenta-se o histórico da problemática da disposição dos RSU na região, realiza-se uma caracterização do lixo urbano local e apresenta-se uma descrição do sistema de gerenciamento existente e das alternativas já apresentadas oficialmente às municipalidades.

Uma revisão do estado da arte da tecnologia de incineração de RSU é colocada no quarto capítulo. Uma das questões mais importantes levantadas durante a análise de sistemas de tratamento e destinação do lixo é a questão de poluição ambiental. Desta forma, no capítulo 5 é realizada uma análise qualitativa das emissões atmosféricas resultantes da queima de RSU em um incinerador. Em particular, trata-se da emissão de metais pesados, particulados, gases ácidos e de dioxinas e furanos.

No capítulo 6, analisa-se a opção de incineração do lixo urbano no ABCD.. Esta análise é realizada a partir da escolha de uma determinada tecnologia em função dos dados técnicos e econômicos disponíveis. O capítulo 7 é reservado para as discussões dos resultados obtidos e apresentação de sugestões. 


\section{3- O ABCD}

No item 1.1 apresentou-se a sub-região sudeste da RMSP, ABCD.RP.RGS, como sendo uma região extremamente conurbada, com densidade demográfica relativamente elevada e com sérias restrições ambientais. Foi dito ainda que esta região possui problemas de deposição dos resíduos ali gerados. Neste item 1.3 procura-se descrever mais detalhadamente a região discorrendo sobre seus aspectos demográficos, econômicos e ambientais. Apresenta-se também uma análise da atual situação enfrentada por estes municípios com relação ao resíduos urbanos. A descrição sucinta do problema, seu histórico e perspectivas futuras será realizada no capítulo 3 , juntamente com a caracterização do lixo local.

\subsection{1- Aspectos Sócio-Econômicos}

Os sete municípios que compoem a região sudeste da Região Metropolitana de São Paulo são resultado dos sucessivos desmembramentos do Município de Santo André após 1944. Estes municípios ocupam uma área de $841 \mathrm{Km}^{2}$ (10\% da RMSP) limitados a norte e leste pelo restante da RMSP e a oeste e sul pela Represa Billings e Reserva Estadual da Serra do Mar. (EMPLASA, 1994)

A população residente total destes municípios é de aproximadamente 2 milhões de habitantes ( $13 \%$ da RMSP), quase a totalidade em área urbana conforme mostrado na tabela 1.1, resultando em densidades demográficas variando entre 795 hab/km2 (Ribeirão Pires) a 12.434 hab/km2 (Diadema). A densidade demográfica. discriminada por município, é mostrada na tabela 1.2. Em geral, a região possui grandes áreas de ocupação irregular ou sub-habitações, predominantemente de baixa renda. O relevo de morros e colinas, característico da região. contribui significativamente para 0 adensamento populacional. 
Tabela 1.1 - População Residente por Situação do Domicilio

\begin{tabular}{|c|c|c|c|c|c|c|c|c|}
\hline & \multicolumn{3}{|c|}{1970} & \multicolumn{2}{|c|}{1980} & \multicolumn{3}{|c|}{1991} \\
\hline & Urbana & Rural & Total & Urbana & Total & Urbana & Rural & Total \\
\hline Diadema & 68513 & 10401 & 78914 & 228660 & 228660 & 305067 & 0 & 305067 \\
\hline Maua & 101542 & 158 & 101700 & 205740 & 205740 & 294631 & 0 & 294631 \\
\hline Ribeirao Pires & 24095 & 4953 & 29048 & 565362 & 565362 & 85035 & 0 & 85035 \\
\hline Rio Grande da Serra & 7278 & 1119 & 8397 & 20093 & 20093 & 29848 & 0 & 29848 \\
\hline Santo Andre & 417264 & 1562 & 418826 & 553072 & 553072 & 615112 & 0 & 615112 \\
\hline São Bernardo & 189309 & 12353 & 201662 & 384525 & 425602 & 556003 & 11405 & 567408 \\
\hline São Caetano do Sul & 150130 & 0 & 150130 & 163082 & 163082 & 149203 & 0 & 149203 \\
\hline Região Sudeste SP & 958131 & 30546 & 988677 & 2120534 & 2161611 & 2034899 & 11405 & 2046304 \\
\hline Grande São Paulo & 7866669 & 273061 & 8139730 & 12183634 & 12588725 & 15085394 & 332243 & 15417637 \\
\hline
\end{tabular}

Tabela 1.2 - Dados gerais sobre a Região do ABCD

\begin{tabular}{|l|c|c|c|c|c|c|c|}
\hline & \multirow{2}{*}{\begin{tabular}{c} 
Ano \\
\cline { 3 - 8 }
\end{tabular}} & \multicolumn{2}{|c|}{ Área } & \multicolumn{2}{c|}{ População } & $\begin{array}{c}\text { Densidade } \\
\text { demografica }\end{array}$ & $\begin{array}{c}\text { Valor } \\
\text { Adicionado }\end{array}$ \\
\cline { 3 - 8 } & & $\mathrm{km} 2$ & $\%$ & hab & $\%$ & hab/km2 & $\%$ \\
\hline Sanio Andre & 1889 & 179 & $21 \%$ & 615112 & $30 \%$ & 3436 & 4.6 \\
São Bernardo do Campo & 1944 & 411 & $49 \%$ & 567408 & $28 \%$ & 1381 & 9.3 \\
São Caetano do Sul & 1948 & 12 & $1 \%$ & 149203 & $7 \%$ & 12434 & 2.9 \\
Mauá & 1953 & 67 & $8 \%$ & 294631 & $14 \%$ & 4397 & 3.7 \\
Diadema & 1958 & 32 & $4 \%$ & 305067 & $15 \%$ & 9533 & 3.2 \\
Ribeirão Pires & 1953 & 107 & $13 \%$ & 85035 & $4 \%$ & 795 & 0.6 \\
Rio Grande da Serra & 1963 & 33 & $4 \%$ & 29848 & $1 \%$ & 904 & 0.1 \\
\hline Regiao Sudeste & - & 841 & $10 \%$ & 2046304 & $13 \%$ & 2433 & 24.3 \\
\hline Grande São Paulo & - & 8051 & & 15417637 & & 1915 & 54.1 \\
\hline
\end{tabular}

Obs: População segundo dados preliminares do Censo 1991 e Valor Adicionado Fund. SEADE 1991.

Fonte: EMPLASA. 1994

Estes municipios caracterizam-se ainda por uma forte atividade industrial, principalmente Santo André, São Bernardo do Campo, São Caetano e Diadema, contribuindo, em 1991, com 24\% do valor adicionado da RMSP (EMPLASA, 1994). Esta atividade industrial se desenvolveu principalmente após a década de 1960 e serviu como atrativo a correntes migratórias de outras regiões do país. Entre 1970 e 1980, a região sofreu uma "explosão" populacional claramente observada nos índices de crescimento demográfico colocados na tabela 1.3. Estas altas taxas de crescimento provocaram uma ocupação desordenada das áreas e. conseqüentemente, o descompasso da infraestrutura urbana. A década de 1980 se caracterizou por uma estagnação 
produtiva do país, fato refletido no crescimento da região o que vem a fortalecer a afirmativa do vínculo entre a atividade industrial e a população da região.

Tabela 1.3: Crescimento Populacional por Município e Situação do Domicilio, 70-80, 80-91, 70-91 (em \% a.a.)

\begin{tabular}{|l|c|c|c|c|c|c|c|c|c|}
\hline & \multicolumn{3}{|c|}{$1970-1980$} & \multicolumn{3}{c|}{$1980-1991$} & \multicolumn{3}{c|}{$1970-1991$} \\
\hline & Urbana & Rural & Total & Urbana & Rural & Total & Urbana & Rural & Total \\
\hline Diadema & $13 \%$ & $-7 \%$ & $11 \%$ & $3 \%$ & $0 \%$ & $3 \%$ & $7 \%$ & $-3 \%$ & $7 \%$ \\
Maua & $7 \%$ & $-7 \%$ & $7 \%$ & $4 \%$ & $0 \%$ & $4 \%$ & $5 \%$ & $-3 \%$ & $5 \%$ \\
Ribeirao Pires & $37 \%$ & $-7 \%$ & $35 \%$ & $-6 \%$ & $0 \%$ & $-6 \%$ & $6 \%$ & $-3 \%$ & $5 \%$ \\
Rio Grande da Serra & $11 \%$ & $-7 \%$ & $9 \%$ & $4 \%$ & $0 \%$ & $4 \%$ & $7 \%$ & $-3 \%$ & $6 \%$ \\
Santo Andre & $3 \%$ & $-7 \%$ & $3 \%$ & $1 \%$ & $0 \%$ & $1 \%$ & $2 \%$ & $-3 \%$ & $2 \%$ \\
São Bernardo do Campo & $7 \%$ & $13 \%$ & $8 \%$ & $4 \%$ & $-6 \%$ & $3 \%$ & $5 \%$ & $-0.4 \%$ & $5 \%$ \\
São Caetano do Sul & $1 \%$ & $0 \%$ & $1 \%$ & $-1 \%$ & $0 \%$ & $-1 \%$ & $-0.03 \%$ & $0 \%$ & $-0.03 \%$ \\
\hline Região Sudeste SP & $8 \%$ & $3 \%$ & $8 \%$ & $0 \%$ & $-6 \%$ & $-1 \%$ & $4 \%$ & $-2 \%$ & $4 \%$ \\
\hline Grande São Paulo & $4 \%$ & $4 \%$ & $4 \%$ & $2 \%$ & $-2 \%$ & $2 \%$ & $3 \%$ & $1 \%$ & $3 \%$ \\
\hline
\end{tabular}

Fonte: IBGE, Censos Demograficos 1970,1980 e Resultados Preliminares do Censo 1991 apud EMPLASA

Este acelerado crescimento fez com que, desde o final da década de 60 , as manchas urbanas destes municípios e do município de São Paulo viessem a se interligar gerando beneficios econômicos para ambos mas também trazendo os problemas característicos de regiões metropolitanas. Na verdade. as fronteiras entre os municípios são mais legais que reais, com muitos bairros e sistema viário contínuos. Estes fatos suportam a afirmação de que estes municípios devem procurar soluções conjuntas para seus problemas de infraestrutura e planejamento regional. Esta sugestão é constante em todos os estudos realizados desde o início da década de 70. Entretanto, devido a problemas de articulação política. muitas das soluções empregadas até hoje tem sido individuais ou, no máximo, acordadas entre dois ou três municípios.

Em 1990, sentindo a necessidade de uma busca comum para o problema da destinação final dos resíduos sólidos. as prefeituras locais constituiram um consórcio, na época denomidado Consórcio Intermunicipal das Bacias do Alto Tamanduatei e Billings, hoje Consórcio Intermunicipal Grande $\mathrm{ABC}$. Dentre os objetivos estabelecidos no estatuto, encontra-se a busca de soluções adequadas para os problemas comuns aos seus integrantes incluindo a coleta. tratamento e disposição final dos resíduos sólidos. 


\subsection{2- Previsões de crescimento}

Serão necessárias. no decorrer desta dissertação, previsões do volume gerado de resíduos no futuro. Estas previsões são realizadas através da estimativa da população residente no município, o que desenvolve-se neste sub-item.

Basea-se esta estimativa a partir da taxa de crescimento geométrico anual da população. Para o ABCD, esta taxa deve apresentar um comportamento mais estável nos próximos anos principalmente devido a:

a) As altas taxas apresentadas durante a década de 1970 ocorreram simultâneamente ao desenvolvimento acelerado da região: apesar de ser possível a instalação de novas unidades produtivas. este fenômeno não deverá ser tão dramático como na fase inicial e, dada a tendência de automação do setor metalúrgico moderno, se ocorrer, não será tão intensiva em mão de obra:

b) Em grande parte dos municípios da região, a densidade populacional já é bastante elevada e existe uma relativa escassez de novas áreas para empreendimentos. A maior parte das áreas hoje desocupadas. ou com ocupação irregular estão dentro de APMs o que inviabiliza grandes projetos imobiliários;

c) Justamente por ter aproximadamente 50\% do seu território em APM, estes municípios terão dificuldades,junto aos orgãos estaduais de meio ambiente e junto à população, de aprovar a instalação de novas indústrias.

Considerando as colocações acima, é razoável admitir um crescimento demográfico entre 1 e $2 \%$ ao ano entre 1991 e 2010. A previsão de população para os municípios do ABCD está mostrada na tabela 1.4 abaixo.

Tabela 1.4- População residente no ABCD: 1991 e estimativas para 2010

\begin{tabular}{|l|c|c|c|}
\hline \multirow{2}{*}{ Município } & \multicolumn{3}{|c|}{ População Residente } \\
\cline { 2 - 4 } & 1991 & 2010 - baixa & 2010 - Alta \\
\hline Diadema & 305067 & 368554 & 444425 \\
Mauá & 294631 & 355946 & 429222 \\
Ribeirão Pires & 85035 & 102732 & 123880 \\
Rio Grande da Serra & 29848 & 36060 & 43483 \\
Santo André & 615112 & 743122 & 896102 \\
São Bernardo do Campo & 567408 & 685491 & 826603 \\
São Caetano do Sul & 149203 & 180253 & 217361 \\
Região sudeste da RMSP & 2046304 & 2472158 & 2981079 \\
\hline
\end{tabular}

1 - Baixa $1 \%$ a.a. Alta: $2 \%$ a.a.

Obs: Estimativas realizadas pelo autor. 


\subsection{3- Meio Ambiente}

$\mathrm{O}$ meio ambiente da região do grande $\mathrm{ABCD}$ é bastante complexo e pode ser claramente identificado como uma área de conflito entre o ambiente natural e a ocupação do homem. Apesar do lago existente na região (Represa Billings) ser artificial (construido em 1949 para o aumento do potencial hidroelétrico da Usina Henry Borden), esta modificação antropogênica tem sido considerada definitiva e tratada como um sistema natural. Uma parte isolada da represa. o Reservatório Rio das Pedras, serve como ponto de captação da água de abastecimento público da região do $\mathrm{ABCD}$. Existem previsões para a ampliação do uso da água da represa para o abastecimento público.

Este uso das águas da Represa Billings determinou o enquadramento de grande parte da região como área de proteção de mananciais (APM) pela lei estadual 898/75. Esta lei constituiu-se no maior condicionante do uso do solo e tornou clara a importância do controle da poluição na região. Conforme pode ser visto na tabela $1.5,56 \%$ da área do $\mathrm{ABCD}$ está dentro de APM, inclusive com 2 municípios (Ribeirão Pires e Rio Grande da Serra) possuindo $100 \%$ de seu território dentro de APM. Esta classificação impossibilita a expansão maciça da ocupação humana e a instalação de dispositivos industriais ou ainda, o que é pertinente a esta dissertação. de aterros sanitários. Nas margens opostas da Represa Billings, em relação à grande São Paulo. encontra-se a vertente da Serra do Mar. Esta área está coberta por remanescentes da Mata Atlântica e é protegida como Reserva Florestal Estadual.

Tabela 1.5: Classificação das Áreas dos Municipios segundo a Lei de Proteção dos Mananciais. 1992

\begin{tabular}{|l|c|c|c|c|c|}
\hline \multirow{2}{*}{} & \multicolumn{5}{|c|}{ Área (km2) } \\
\cline { 2 - 6 } & $\begin{array}{c}\text { Dentro } \\
\mathrm{km} 2\end{array}$ & $\%$ & $\begin{array}{c}\text { Fora } \\
\mathrm{km} 2\end{array}$ & $\%$ & $\begin{array}{c}\text { Total } \\
\mathrm{km} 2\end{array}$ \\
\hline Diadema & 7 & 21.9 & 25 & 78.1 & 32 \\
Maua & 13 & 19.4 & 54 & 80.6 & 67 \\
Ribeırao Pires & 107 & 100 & 0 & 0 & 107 \\
Rio Grande da Serra & 33 & 100 & 0 & 0 & 33 \\
Santo Andre & 96 & 53.6 & 83 & 46.4 & 179 \\
São Bernardo do Campo & 216 & 52.6 & 195 & 47.4 & 411 \\
São Caetano do Sul & 0 & 0 & 12 & 100 & 12 \\
\hline Região Sudeste SP & 472 & 56.1 & 369 & 43.9 & 841 \\
\hline Grande São Paulo & 4346 & 54 & 3705 & 46 & 8051 \\
\hline
\end{tabular}


O mapa esquemático colocado na figura 1.1 mostra as áreas com restrição do meio físico à implatação de aterros levantadas pela EMPLASA. As restrições legais associadas ao meio ambiente impedindo o tratamento e disposição de resíduos são mostradas na figura 1.2. Um dos problemas existentes nesta área é justamente a pressão demográfica e a necessidade de expansão da área urbana. A figura 1.3 mostra a extensão da mancha urbana em 1990. Criando uma superposição destas restrições pode-se claramente observar o esgotamento de áreas disponíveis para tratamento e deposição de resíduos na região metropolitana e, em especial, na sub-região sudeste. 
A PRODUÇÃO, A COLETA E A DESTINAÇÃO FINAL DOS RESIDUOS SÓLIDOS NA RMSP INADEQUAÇÃO DAS SOLUÇÕES - RESTRIÇŌES DO MEIO FISICO
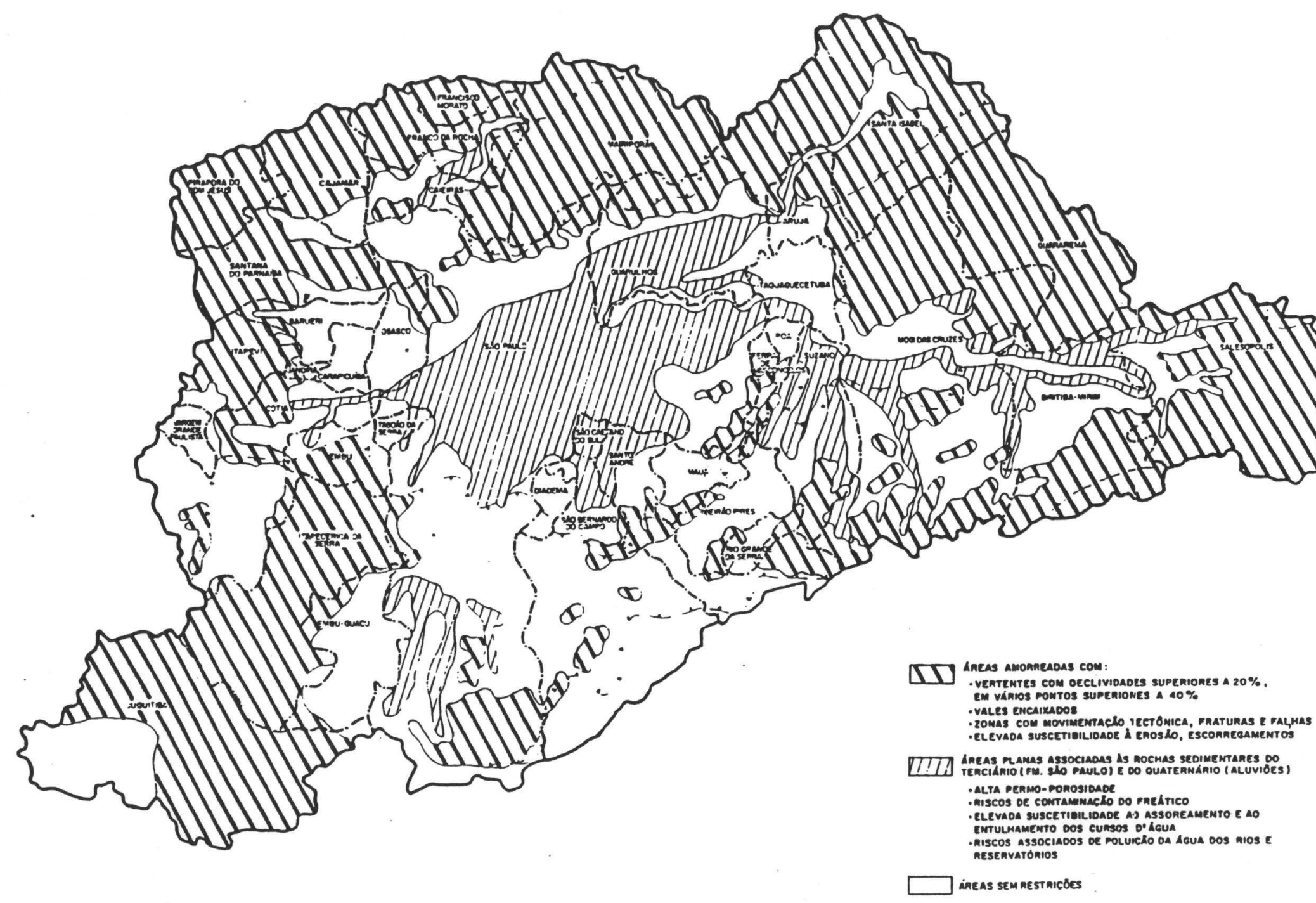
A PRODUÇÃO, A COLETA E A DESTINAÇÃO FINAL DOS RESIDUOS SÓLIDOS NA RMSP INADEQUAÇÃO DAS SOLUÇÕES - RESTRIÇŌES LEGAIS

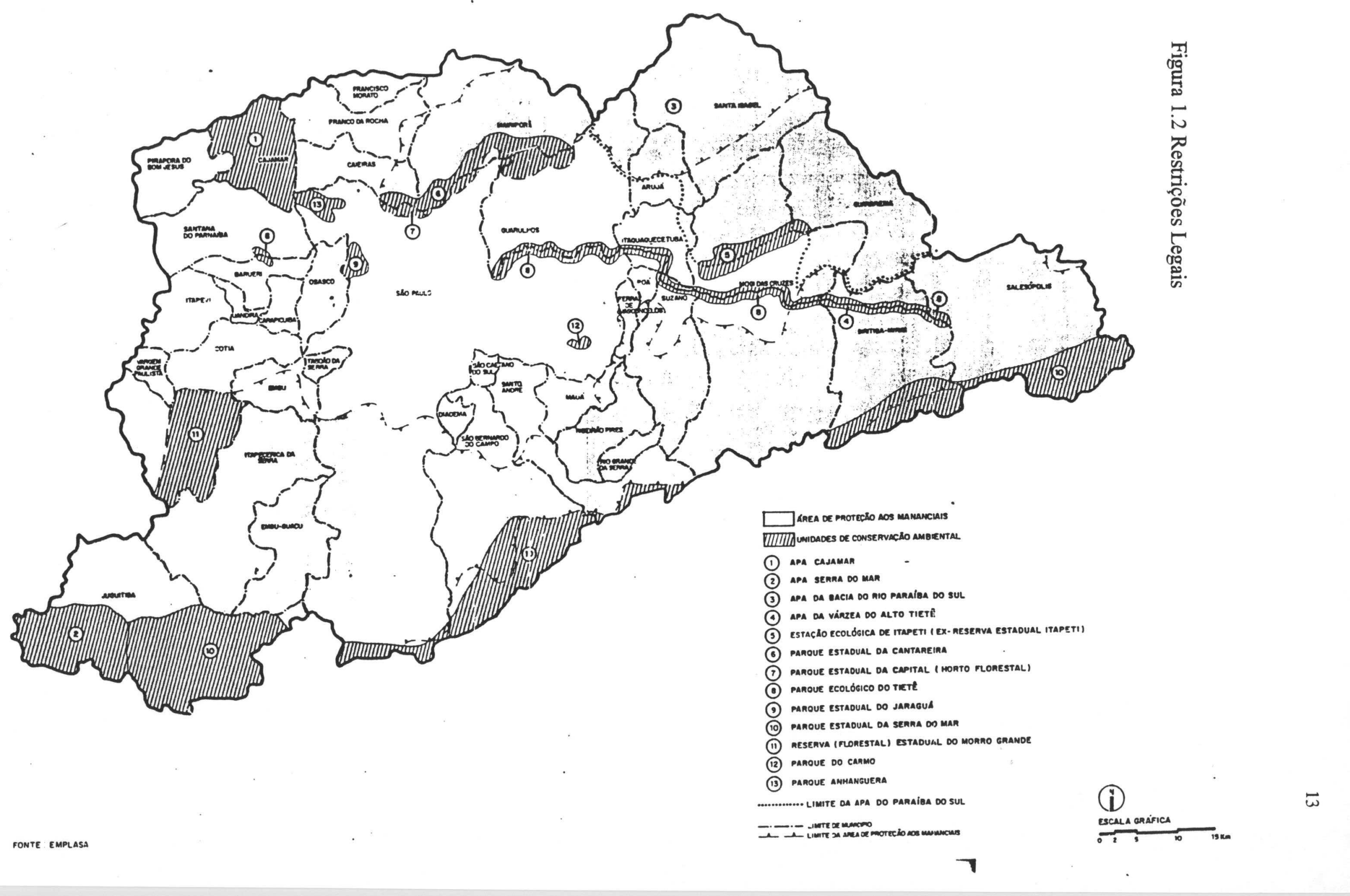


A PRODUÇĀO, A COLETA EA DESTINAÇÃO FINAL DOS RESÍDUOS SÓLIDOS NA RMSP DISPOSICÁO FINAL DE REŚIDUOS SÓLIDOS A CÉU ABERTO - LIXÖES - 1991

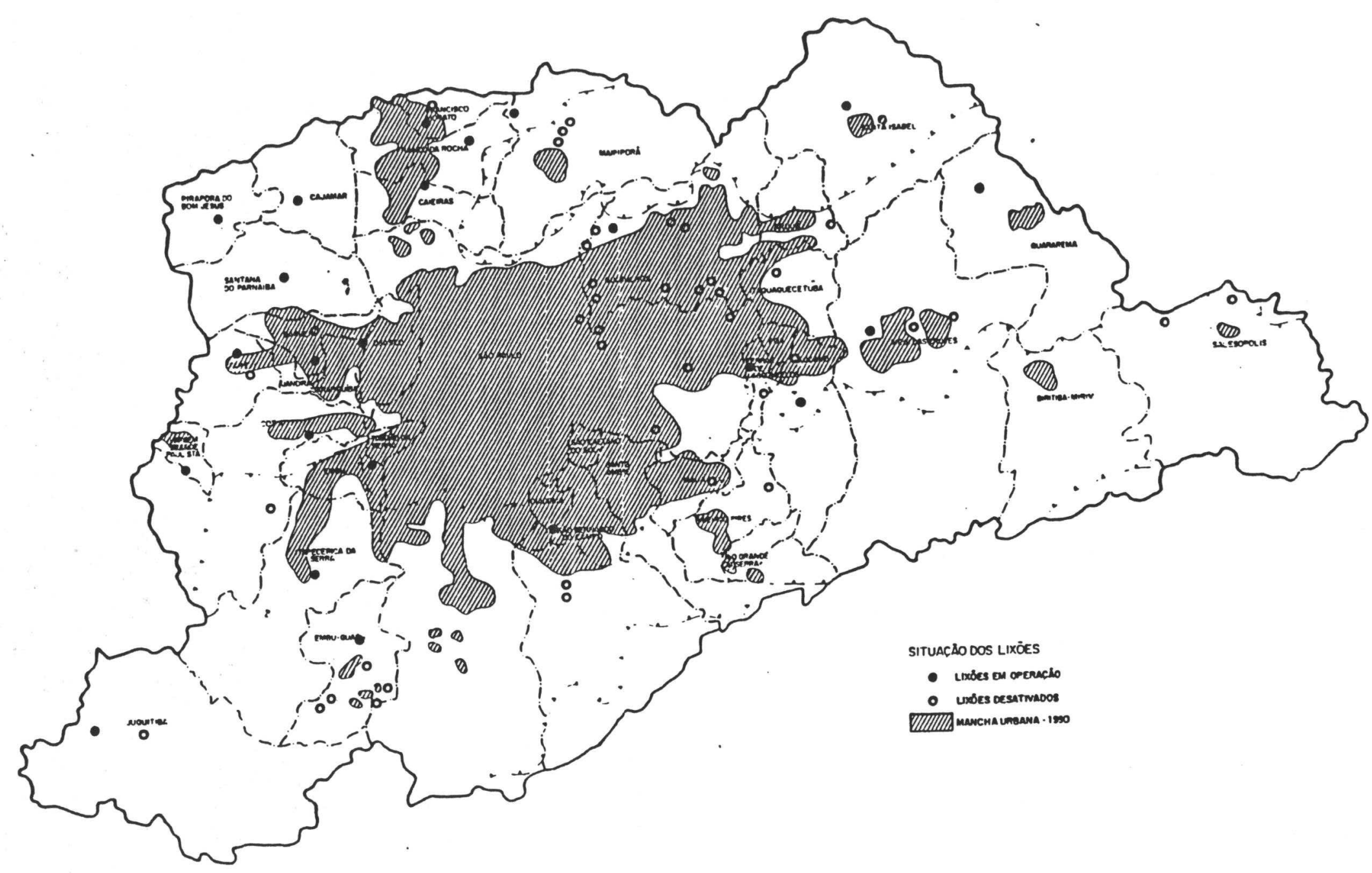

畒 


\section{Capítulo 2}

\section{Resíduos Urbanos: Caracterização e Opções de Tratamento}

A questão dos resíduos sólidos urbanos é tão antiga quanto a formação de cidades. As soluções encontradas foram se modificando lentamente durante a história de acordo com as necessidades de cada sociedade. Mais recentemente, a gerência de resíduos sólidos tornou-se uma disciplina dotada de alto dinamismo com novas soluções sendo elaboradas e testadas em todo o mundo. Entre os métodos de gerenciamento atuais, o Gerenciamento Integrado de Resíduos Sólidos representa a tendência internacional e os resultados de sua aplicação têm se mostrado favoráveis.

Um estudo de gerenciamento de RSU, contemplando formas de tratamento e destinação final dos resíduos inicia-se pela determinação das características dos resíduos. Esta determinação, ou caracterização. é primordial para o correto direcionamento do estudo e deve ser desenvolvida de forma cuidadosa.

A partir do caracterização do resíduo, procede-se ao estudo das técnicas disponiveis de gerenciamento, tratamento ou disposição final com o objetivo de avaliar os impactos técnicos, econômicos e sociais da adoção de cada uma destas técnicas.

Neste capitulo desenvolve-se a análise partindo da caracterização dos resíduos sólidos urbanos. A seguir descreve-se os sistemas existentes para tratamento e destinação final contemplando neste contexto, as técnicas de gerenciamento integrado de RSU. 


\section{1- Caracterização dos Resíduos}

A caracterização dos residuos inicia-se pela classificação e pela determinação da composição média e das propriedades fisico-químicas. A classificação separa os diversos tipos de resíduos em categorias homogêneas, permitindo a existência de legislação específica a cada uma, bem como o estudo de formas de tratamento e destinação finais compatíveis.

Resíduos são usualmente definidos como todos os "tipos, tamanhos e configurações de materiais que não possuem uma utilidade aparente" (Brunner, 1991). $\mathrm{Na}$ legislação federal do meio ambiente brasileira, encontramos uma definição similar baseada na utilidade do material:

"Característica básica na conceituação de resíduo é a condição de inutilidade, indesejabilidade ou descartabilidade do material em relação à sua utilização inicial. Os resíduos abrangem ou têm sinônimos de uso corrente: as sucatas, os desperdícios, as cinzas, os rejeitos, as borras, os lodos, os pós, os cavacos, as granalhas, as limalhas, os descartes. as aparas, as sobras, as carcaças e os lixos;" (IBAMA, Portaria Normativa $\mathrm{N}_{-}^{\circ}$ 138 de $22 / 12 / 1992$, parag. $1_{-}^{\circ}$ e $2_{-}^{\circ}$ )

Esta conceituação. encontrada na legislação brasileira, é restritiva por fazer referência "à sua utilização inicial". Esta conceituação deixa implícita uma utilidade prévia do material, o que nem sempre é verdade. Pode-se citar, por exemplo, o caso do gás natural que, durante muito tempo foi considerado um "resíduo" da produção de petróleo e era lançado livremente ou queimado na "boca do poço"; neste período o gás natural era um residuo uma vez que não havia uma utilização econômicamente viável para ele. Com as mudanças dos preços e disponibilidades de combustível, o gás natural deixou de ser considerado um resíduo e se tornou um recurso.

Desta forma, a classificação de Bruner é mais abrangente e apropriada. No decorrer do tempo. outros materiais ou substâncias deixarão de ser considerados resíduos para ter um aproveitamento posterior. Este aproveitamento, determinado pela escassez, preços dos recursos ou pelo descobrimento de novas utilidades, possibilitará o 
melhor aproveitamento dos recursos naturais e a diminuição do impacto humano sobre o meio ambiente.

\subsection{1- Classificação genérica \\ Os resíduos podem ser classificados segundo o estado fisico, origem,} propriedades, etc. Algumas das possiveis classes de resíduos estão mostradas abaixo:

\begin{tabular}{lll}
\hline Estado & Origem & Caracteristica \\
\hline & Industriais & \\
Sólidos & Comerciais & Inertes \\
Líquidos & Residenciais & Putreciveis \\
Gasosos & de Limpeza Pública & Perigosos \\
& Hospitalares & \\
\hline
\end{tabular}

Estas classes se interconectam. determinando as diversas denominações de uso corrente (esgotos domésticos: resíduos líquidos residências e comerciais, entulhos: resíduos sólidos inertes, etc). A legislação é realizada considerando os aspectos comuns, podendo ou abranger somente uma classe, ou abranger simultâneamente diversas classes. Os resíduos gasosos que são regulados inteiramente pela legislação de poluição do ar elaboradas pelo CONAR, e os resíduos líquidos são separados como esgotos domésticos ou industriais e com legislações distintas.

Os resíduos sólidos são usualmente separados pela origem e potencial poluidor. O esquema colocado na figura 2.1 mostra a classificação usual de resíduos sólidos. Os resíduos sólidos residenciais, comerciais e resultantes do serviço de limpeza pública (varrição, capina, podas) são normalmente agrupados em uma classe denominada de Resíduos Sólidos Urbanos, ou na forma usual. lixo urbano. A coleta, tratamento e 
destinação destes residuos fazem parte dos serviços de saneamento básico e. mais especificamente. do Serviço de Limpeza Pública.

\subsection{2- Resíduo sólido urbano}

Conforme mostrado na figura 2.1, considera-se resíduo sólido urbano aqueles resíduos gerados nas diversas atividades dos setores residencial, comércio e serviços e naquelas ligadas à limpeza dos locais públicos.

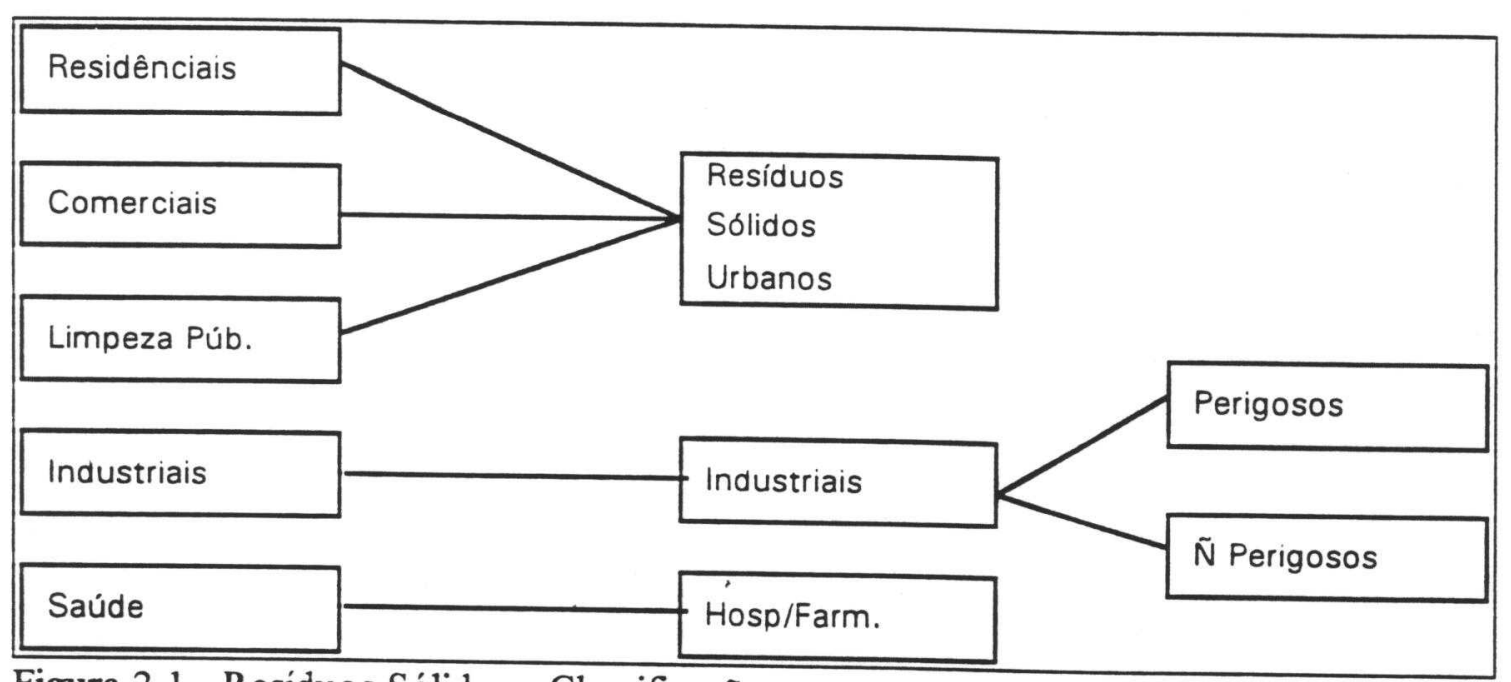

Figura 2.1 - Resíduos Sólidos - Classificação

Apesar de não definir explicitamente como responsabilidade única dos muncípios a coleta e tratamento dos resíduos sólidos urbanos. a constituição brasileira estabelece como competência dos municípios legislar sobre os assuntos de interesse local (Art.26, inciso I). Tradicionalmente. os serviços de lixo são considerados assuntos de interesse local e, entầo, geridos pelas municipalidades. As prefeituras se responsabilizam pela prestação deste serviço, executando elas próprias ou através de concessão a terceiros, respeitadas as restriçōes impostas pela legislação estadual e federal relativas à poluição 
ambiental, proteção à saúde pública e ao meio ambiente. uma vez que a estas instâncias do poder público cabe legislar sobre as matérias citadas (Const.Fed.Art. 24) ${ }^{1}$.

Dada a diversidade de atividades geradoras e a infinidade de aparatos, embalagens e hábitos alimentares, culturais, etc, o lixo urbano é uma mistura extremamente heterogênea. Esta heteregeneidade o distingüe do lixo industrial ou agrícola que possuem uma composição mais homogênea e previsível. Para um estudo do lixo é preciso conhecer diversos parâmetros da geração e composição tais como:

- Parâmetros Gerais: Composição das frações de peso (percentagem de papel, metais, vidro, etc) e Frações de peso processáveis (percentagem em peso de comburentes, não comburentes. materiais recicláveis, etc)

- Parâmetros Físicos: Volume e peso total forma e tamanho dos componentes, solubilidade, combustibilidade, calor específico. condutibilidade térmica. fração volátil e cinzas, ponto de fusão das cinzas, etc.

- Parâmetros químicos: Componentes químicos, fração orgânica e inorgânica, poder calorífico, produtos de combustão, etć.

- Particularidades: variação sazonal, risco de presença de elementos perigosos, etc.

A composição do lixo urbano sofre variações seculares. cíclicas e aleatórias. As variações seculares devem-se à mudança dos hábitos e costumes através do tempo, do aparecimento de novos produtos e embalagens e das mudancas de poder aquisitivo. Esta é uma mudança extremamente lenta, notada somente quando são comparadas composições do lixo de décadas distintas. As variações cíclicas podem acompanhar estações do ano ou mesmo flutuações cíclicas da economia. A variação dada pelas estações do ano é a mais previsivel e impacta sensivelmente as propriedades do lixo urbano. As variações cíclicas podem ainda ser diárias, seguindo hábitos ou atividades

\footnotetext{
${ }^{1}$ Ainda sobre a questão instituicional do lixo no $\mathrm{ABCD}$. uma análise mais profunda é realizada no trabalho: OLIVEIRA. Clecia. Planejamento e Politica: o caso do lixo no Grande ABC. FGV, 1988. [Diss. Mestrado].
} 
desempenhadas em dias específicos (feiras livres. produtos com consumo maior em finais de semana. feriados. etc). Recomenda-se. na análise do lixo de determinado local. a coleta de amostras em dias de semana distintos e em diversas épocas do ano.

A tabela 2.1 mostra a composição do lixo urbano de diversas cidades. A variação encontrada é uma mostra da influência dos diferentes hábitos de consumo em cidades e épocas distintas. A diferença de poder aquisitivo da população também é um fator que

Tabela 2.1- Composição física média do Lixo Urbano de diversas cidades

\begin{tabular}{|c|c|c|c|c|c|}
\hline & B. Horizonte ${ }^{\prime}$ & $A B C D, 1972^{2}$ & S.Paulo, $1988^{9}$ & $A B C D 1992^{7}$ & S.Paulo, $91^{10}$ \\
\hline Papel & 10.7 & 21.8 & $28.4^{3}$ & 4.4 & $13.1^{11}$ \\
\hline Papelão & 2.8 & 4.1 & - & 2.5 & \\
\hline Vidro & 2.2 & 2.1 & 3.1 & 1.2 & 1.7 \\
\hline Madeira & 0.6 & 1.9 & 1.6 & 0.4 & 0.8 \\
\hline Mat.Org. Putrec. & 64.4 & 43.5 & 52.5 & $74.6^{8}$ & 62.0 \\
\hline Metal Ferroso & 2.5 & 3.9 & 4.9 & 2.7 & 2.9 \\
\hline Metal ñ ferroso & 0.2 & 0.3 & . & 0.4 & 0.6 \\
\hline Tecidos & 1.5 & 3.4 & 2.3 & 3.5 & $5.2^{12}$ \\
\hline Couro & 0.2 & 0.9 & $0.7^{5}$ & 0.3 & \\
\hline Plasticos Duros & 1.8 & - & - & 2.0 & \\
\hline Plasticos outros & 4.7 & $4.3^{4}$ & $5.6^{4}$ & 7.5 & $11.1^{4}$ \\
\hline Borracha & 0.4 & 0.6 & - & - & \\
\hline Folhagem & 5.4 & 4.1 & - & - & \\
\hline Inertes(pedras...) & 2.6 & 9.1 & $0.9^{6}$ & 0.5 & $2.6^{13}$ \\
\hline
\end{tabular}

1. Pref. de Belo Horizonte. Superintendencia de Serviços urbanos, 1991

2. SERETE. 1973

3. Papel e palelao

4. Inclui plasticos duros

5. Inclui couro e borracha

6. Inciui pedra e outros

7.FILSAN. 1992

8.Segundo informações obtidas com pessoas ligadas ao projeto e constantes no proprio relatorio final da empresa (P5) este valor pode estar distorcido para cima uma vez que a amostragem ter comcidido com dias de feira-livre.

9. LIMPURB, 1988

10. Pref. Municipal de SP em SCHMMUEL.W: Vitoratto. E.. O Desafio do Lixo Urbamo. Revista Politécnica. s.d

11. Papel, papelao e jornal

12. Trapos. couro e borracha

13. "Diversos"

justifica diferenças na composição do lixo entre locais distintos.

A determinação da composição é somente uma das etapas na caracterização dos residuos. Seguem-se a ela. conforme mencionado. a determinação de outros parâmetros importantes do lixo urbano. Estes parâmetros também variam geograficamente e 
sazonalmente. Além destes. uma análise química deve ser realizada com vistas à determinação das quantidades presentes de carbono. hidrogênio, enxofre, oxigênio, nitrogênio, elementos halogênicos (flúor, cloro. etc), metais pesados (mercúrio, chumbo, etc) e outros elementos químicos que possam afetar o processo de combustão. Somente com esta análise completa é possível prever os produtos resultantes dos diversos processos de tratamento dos resuduos sólidos.

\section{2 - Sistemas de tratamento e destinação final de RSU}

Como Brunner [BRUNNER.1991] menciona, não existe uma resposta simples para o problema da destinação dos resíduos. No decorrer dos séculos, foram surgindo novos processos e tecnologias na busca de uma forma mais segura e cômoda de destinação de tudo aquilo que não mais possui uma utilidade aparente. Cada um dos processos possui vantagens e desvantagens técnicas, econômicas e sociais. $O$ balanceamento correto do emprego de cada processo nas diferentes etapas (coleta, transporte, tratamento. disposição final) é uma das tarefas que mais exige do administrador público.

O serviço de limpeza urbana está ligado aos serviços de saúde pública e de controle da poluição pelo potencial de dano que o mal gerenciamento desta questão pode causar. A coleta. tratamento e deposição inadequada do RSU tem inúmeros impactos socio-econômicos. Apesar de alguns destes impactos negativos serem de conhecimento comum. a questão do lixo é muitas vezes negligenciada. Esta negligência funciona como uma bomba de efeito retardado, mas, nem por isso, menos danosa. Os custos de reparação de danos ao meio ambiente e a populações causados por problemas de poluição são reconhecidamente maiores do que os de prevenção.

O gerenciamento correto da questão só é possível a partir do conhecimento dos parâmetros do lixo local, conforme colocado anteriormente, e das técnicas disponíveis para este gerenciamento. Estas técnicas e práticas disponíveis para RSU podem ser resumidas conforme mostrado no quadro abaixo. 
- Técnicas de redução

Redução na fonte

Reciclagem

- Técnicas de tratamento

Compostagem

Fermentação

Destruição quimica

Queima

Pirólise

Incineração

- Técnicas de disposição final

Deposição a ceu aberto (lixão)

Aterramento

Controlado

Sanitario

Deposição no oceano

Figura 2.2 - Técnicas de Gerenciamento de RSU

\subsubsection{Técnicas de Redução}

A redução na fonte envolve a análise dos resíduos gerados por um produto desde sua fabricação até seu descarte. Esta análise é denominada de Análise do Ciclo de Vida e pode ser resumida na figura 2.3 a seguir

A abordagem proposta baseia-se no fato de que os tomadores de decisão normalmente olham somente para o lixo já produzido para tomar sua decisão, ignorando oportunidades de redução do volume total gerado ou modificações na sua composição que facilitariam sua disposição final [BRIDGES e CURRAN,1994]. Na Europa o termo "Ecobalance" é mais utilizado para esta abordagem. Um dos exemplos deste tipo de análise é o incentivo ao uso de embalagens que considerem o resíduo final. Conforme alerta Bickerstaffe [BICKERSTAFFE.1994] esta solução com relação a embalagens deve ser adotada com critério sob o risco de se aumentar o resíduo gerado pela perda de produtos. 


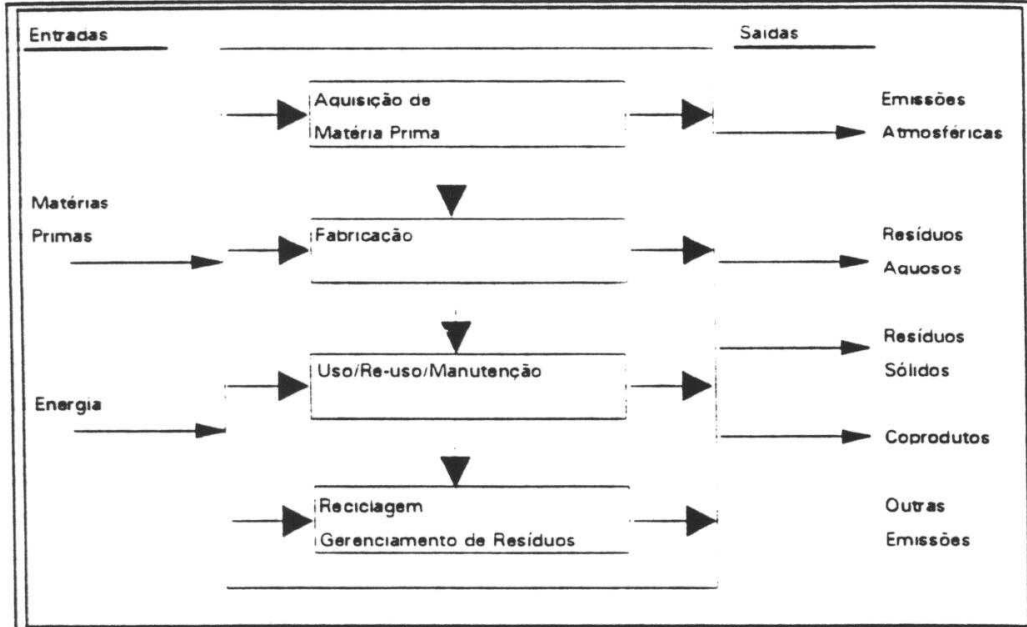

Figura 2.3 - Estágios do ciclo de vida de um produto Fonte: BRIGGES e CURRAN. 1994.

A reciclagem de produtos é outra das técnicas disponíveis para a redução da quantidade dirigida a uma destinação final. A experiência da cidade de Curitiba, onde foi implantado um programa com bastante sucesso, a seleção de lixo reciclável já nas residências diminuiu em $20 \%$ o volume encaminhado ao aterro municipal (MARINI, 1992). Existem diversas variantes logísticas para a implementação de um programa de reciclagem. O objetivo primário da reciclagem é a redução do uso de materias primas e do uso global de energia, entretanto. a preponderância de um ou outro fator deve ser determinada uma vez que estas duas variáveis não são independentes. A Figura 2.4 mostra um gráfico hipotético do uso global de energia em função da quantidade reciclada. Podemos observar que a partir de determinado valor de reciclagem de um material, o uso global de energia ultrapassa o nível do uso sem reciclagem. Se o fator preponderante para a sociedade for a redução do consumo de energia, então a fração objetivo da reciclagem deve ser $F_{2}$, se for a máxima reciclagem do material sem aumento do gasto de energia. $F_{1}$ deve ser a fração almejada. 


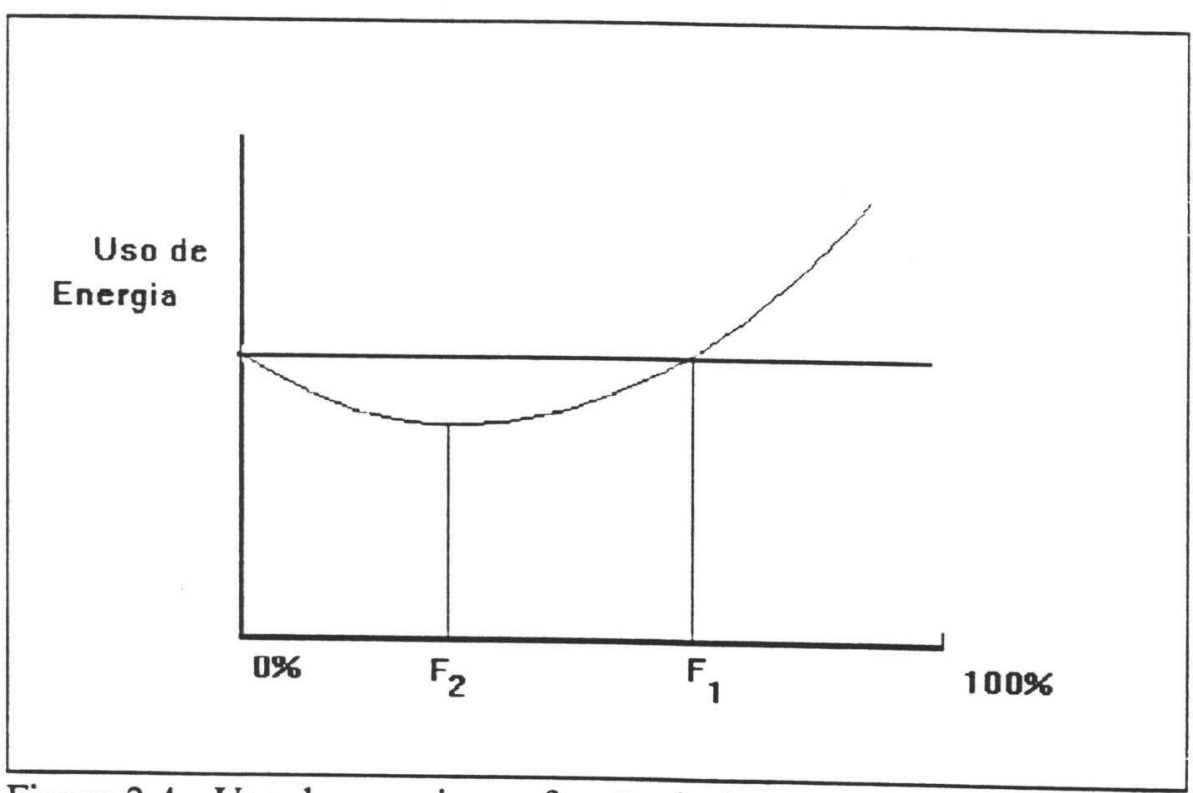

Figura 2.4 - Uso de energia em função da fração reciclada. Fonte: BRIDGES e CURRAN. 1994.

\subsubsection{Técnicas de Tratamento}

A compostagem é o processo de transformação da matéria orgânica presente no lixo via digestão aeróbica em um produto estável, rico em nutrientes, o qual pode ser utilizado como fertilizante. Este processo envolve a separação do lixo para retirada de metais, vidros, plásticos e outros produtos não "digeríveis" pelas bactérias, trituração do lixo a uma granulometria aceitável, correção do $\mathrm{pH}$, da concentração de nitrogênio e fósforo e. finalmente, agitação do material com fornecimento suficiente de ar e mantendo a temperatura nos níveis ótimos para o crescimento das bactérias. Após um período de digestão na usina de aproximadamente cinco dias, o composto é colocado ao ar livre por um periodo entre dez e sessenta dias para finalização do processo e estabilização. $O$ maior problema envolvido no processo é comercialização do produto final. Mesmo um composto livre de plásticos e outras impurezas tem dificil aceitação. A compostagem do lixo recolhido bruto, isto é. sem uma pré-seleção ainda na residência, gera um produto de qualidade sempre duvidosa. podendo sofrer contaminação de metais pesados, fato já confirmado na análise do composto gerado no municipio de São Paulo [FAGA,1993]. 
O processo de fermentação é similar ao da compostagem por ser um tratamento biológico do lixo. Neste caso. a digestão é realizada por bactérias anaeróbicas que produzem metano sendo este aproveitado para geração de eletricidade ou calor. Este gás é comumente conhecido como biogás. O lixo também neste caso deve sofrer uma préseleção antes de ser introduzido no reator. por problemas de volume e para evitar que substâncias nocivas ao leito de bactérias sejam introduzidas. O período de retenção dentro do reator é de aproximadamente 15 dias e o conteúdo de metano no gás gerado fica entre 55 e $65 \%$ [JORMANAINEN, 1994]. Este processo é bastante utilizado na Europa em tratamento de resíduos agricolas (principalmente esterco) ou lama de tratamento de esgotos. $\mathrm{O}$ resíduo do reator pode ser vendido como fertilizante.

Os processos de destruição química envolvem a oxidação ou redução do resíduo. Dentre os processos existentes. destaca-se o de Sal Fundido desenvolvido pela empresa Atomics International (divisão da Rockwell International Corporation) e que possui aplicação com resíduos sólidos. Este processo não é exatamente um processo de incineração porque não é formada chama mas os resíduos são oxidados e/ou quimicamente alterados a substancias inócuas.

Os processos de queima podem ser sub-divididos em duas tecnologias distintas: pirólise e incineração. Nas usinas de pirólise usualmente existem duas câmaras de queima. Na primeira o residuo é queimado em condições de ar sub-estequiométrico gerando um gás com alto teor de monóxido de carbono e hidrogênio, como na gaseificação do carvão. Na câmara secundária é então realizada a combustão completa deste gás. Nos incineradores propriamente ditos, o resíduo, apesar de passar pela fase de pirólise, sofre a combustão completa em uma única câmara. As tecnologias de incineração serão descritas em detalhe no próximo capítulo.

\subsubsection{Técnicas de Destinação Final}

As técnicas ou dispositivos de destinação final representam o ponto em que a sociedade devolye ao meio ambiente tudo aquilo que já não apresenta uma utilidade. A 
forma mais antiga é a simples deposição a céu aberto dos resíduos sólidos. Esta forma de deposição, chamada de lixão. representa uma grave ameaça ao meio ambiente e às próprias comunidades próximas do local pela contaminação do solo, águas superficiais e subterrâneas. além do mal cheiro produzido pela materia orgânica em decomposição. Os lixões são um local de grande potencial de propagação de vetores patogênicos (ratos. mosquitos, etc) representando uma grande ameaça à saúde pública. É tambem usual encontrar nestes locais um grupo de pessoas que reviram os residuos a busca de materiais que possuam ainda algum valor no mercado de recicláveis. Também é comum encontrar criações de animais domésticos (galinhas, porcos) que se alimentam dos resíduos. Todos estes fatores tornam o lixão uma forma extremamente reprovável de deposição (em todos os aspectos, também ilegal) e que traz problemas (e custos) de ordem ambiental. social e econômica durante o período de sua utilização e na sua desmobilização.

O chamado aterro controlado é uma variante menos grave do lixão. Nesta forma de deposição o sítio é escolhido segundo critérios técnicos e é realizado um recobrimento com terra a intervalos regulares. Nenhuma forma de controle ambiental é realizado, não existe sistema de recolhimento de chorume e de ventilação dos gases gerados na decomposição.

Nos aterros sanitários, o resíduo é depositado em camadas recobertas regularmente com terra. Antes da implantação de um aterro sanitário são realizados estudos geológicos e hidrológicos da área verificando os possíveis impactos sobre o meio ambiente. É realizada uma impermeabilização do terreno ${ }^{2}$ e instalam-se redes de dutos para recolhimento do chorume, líquido com altos índices de DBO (demanda biológica de oxigênio) e DQO (demanda química de oxigênio), potencial poluidor de águas subterrâneas. Os resíduos são depositados em células separadas por camadas de

\footnotetext{
${ }^{2}$ No Brasil o usual é a impermeabilização com uma camada de argila compactada, no exterior o recobrimento da camada argilosa com uma ou mais mantas de material sintético impermeável é
obrigatório.
} 
terra e canais de brita para permitir a saída do chamado gás de aterro. Esta é a forma de deposição final mais correta para RSU. considerados os fatores de localização (falhas geológicas, zona de mananciais. etc). Atualmente, preocupações relacionadas com o aumento do efeito estufa forçaram alguns paises a regularem suas emissões de gás de aterro. Nos EUA a EPA (Agência Ambiental do Gov. Americano) determinou que estes gases, deveriam sofrer combustão antes de emitidos à atmosfera. Na Áustria foi fixado o limite máximo de $20 \%$ para o conteúdo de matéria orgânica enviado aos aterros. Estas preocupações se justificam no fato de ser o metano um gás de efeito estufa aproximadamente 80 vezes mais "forte" do que o $\mathrm{CO}_{2}$ [NYSTRÖM,1993].

A deposição em oceanos foi realizada por muitos anos e ainda o é em algumas cidades. Esta forma aproveita-se de formações no fundo do oceano e da capacidade de retenção dos materiais em águas profundas. Esta prática envolve. contudo, sérios riscos ao meio ambiente.

\subsubsection{Gerenciamento Integrado de Resíduos Sólidos}

Conforme afirmado no início deste ítem (2.2), o Gerenciamento Integrado de Resíduos Sólidos Urbanos é uma prática que vem recebendo ampla aceitação entre os decisores municipais. Na verdade. ela faz uso das diversas formas de gerenciamento de resíduos sólidos procurando, através da combinação delas, a minimização das despesas globais com RSU e do impacto ambiental. Os componentes da hierarquia de gerenciamento de RSU - redução na fonte, reciclagem, tratamento e disposição final complementam-se uns aos outros na preparação de um plano estratégico. "Infelizmente, os decisores estão tomando decisões custosas sobre fluxos de resíduos somente com informações limitadas" [BRIDGES, 1994] Esta afirmação mostra que o problema não é restrito ao Brasil. Naquele trabalho advoga-se o uso da abordagem do "Ciclo de Vida dos Produtos". descrita anteriormente neste capitulo, como uma das formas de um maior entendimento da questão antes de uma tomada de decisão. 
Sem se considerar todo o sistema. a adoção de somente uma alternativa, pode resultar em aumentos significativos dos gastos com o serviço de limpeza urbana. Os gastos com limpeza urbana (varrição. coleta. transporte. tratamento e disposição final) ultrapassam. na média das cidades brasileiras, $10 \%$ do orçamento das prefeituras, podendo atingir $20 \%$ nas cidades mais populosas [MARINI, 1992]. A situação na região do $A B C D$ não é diferente, sendo gastos aproximadamente US\$ 19 milhões anualmente com a coleta e destinação dos RSU [FILSAN.1992]. Programas de reciclagem são muito caros para serem implantados sem um planejamento cuidadoso. Como exemplo o custo estimado do programa implantado no município de São Paulo é de US\$ 417 por tonelada reciclada [FAGA, 1993].

A solução do problema passa pela abordagem ampla do problema propiciada pela prática do Gerenciamento Integrado. "O Gerenciamento Integrado com Análise do Ciclo de Vida é uma combinação que requer uma cooperação entre os técnicos responsáveis da municipalidade. os fabricantes e os consumidores para a determinação da melhor opção de gerenciamento de resíduos a nivel local. É certo que as prefeituras deparam-se com uma infinidade de decisões não politicamente populares a respeito do lixo urbano" [BRIDGES, 1994]. A Análise do Ciclo de Vida provê a informação para discussão dos "trade-offs" entre as partes envolvidas na questão.

Os dados apresentados revelam a necessidade de um planejamento cuidadoso para questão. A adoção de determinada alternativa não deve ser feita antes de uma comparação cuidadosa e de uma análise da inserção desta alternativa dentro de todo o cenário dos RSU. É importante destacar esta questão visto que esta dissertação dá um enfoque maior à questão da incineração e não se quer deixar a impressão de ser esta a alternativa - ou a melhor alternativa - para solução da questão do lixo urbano na Região do Grande $A B C D$. Com certeza. a incineração. face as restrições locais. aparece como uma das fortes alternativas de tratamento dos resíduos sólidos na região. Entretanto, no caso da adoção desta alternativa. o sucesso do empreendimento estará ligado a um planejamento cuidadoso envolvendo as outras componentes da solução: programas de 
redução e reciclagem. sistema de coleta. estações de transbordo, compostagem e aterramento.

\subsubsection{Recuperação de Energia}

Um dos objetivos do gerenciamento de resíduos é o melhor aproveitamento dos recursos existentes. A energia. nas suas diversas formas, é o recurso mais necessário a sociedade moderna. Assim. durante os anos foram se desenvolvendo tecnologias para o aproveitamento da energia embutida nos resíduos antes de sua degradação natural. A maior parte das técnicas de gerenciamento discutidas acima possibilitam a recuperação de energia.

A redução na fonte e reciclagem são formas de aproveitamento energético indireto, uma vez que os produtos são fabricados com vistas à esta redução ou materiais já processados são reaproveitados entrando novamente no processo de fabricação em um estágio mais avançado. As grandes reduções do consumo de energia na produção pelo uso de materiais reciclados são reconhecidamente: alumínio, vidro, papel e metais. Estes produtos são o alvo primário de programas de reciclagem. É interessante lembrar que esta redução ocorre até determinada quantidade extraída do lixo. como mostrado na figura 2.4 .

A compostagem também é um processo com recuperação indireta de energia. $\mathrm{O}$ consumo da usina de reciclagem poderia ser comparado àquele da produção de uma quantidade equivalente de fertilizantes.

$\mathrm{Na}$ fermentação existe uma recuperação de energia possibilitada pelo aproveitamento do gás produzido pela digestão do resíduo pelas bactérias. $\mathrm{Na}$ destruição química. considerando o processo exotérmico, é possivel recuperar parte da energia liberada na reação, passando os gases de exaustão por trocadores de calor. Este calor pode ser reaproveitado no processo ou vendido a terceiros como vapor ou eletricidade.

Os processos de queima são processos onde a recuperação de energia se faz diretamente aproveitando o calor liberado na reação de combustão do resíduo. A pirólise 
e incineração são as técnicas mais utilizadas quando se deseja a recuperação de parte da energia embutida nos resíduos coletados. Entretanto, devido aos custos dos equipamentos necessários. esta recuperação só é viável para usinas a partir de determinada escala. Este ponto de viabilidade, entre outros fatores. depende do poder calorífico do resíduo, da tecnologia empregada. do preço de venda da energia e do custo do residuo (na verdade este é um custo negativo, já que as usinas devem cobrar para a prestação do serviço de incineração).

A escala e o custo de capital total também são importantes para a determinação da magnitude dos problemas relacionados às emissões de poluentes. Penner et al. sugerem que seja dada prioridade a incineradores de maior escala pois estes não só minimizariam os custos de controle ambiental como também favoreceriam uma menor emissão de poluentes por tonelada incinerada. A justificativa para esta menor emissão é que incineradores maiores possibilitam a construção de fornalhas mais amplas. com o conseqüente aumento do tempo de residência dos gases permitindo a destruição completa dos elementos tóxicos gerados' na combustão como também dos elementos precursores da formação de dioxinas e furanos [PENNER, 1988].

Uma das preocupações introduzidas recentemente na análise de usinas de queima de resíduos é a variação do poder calorifico do resíduo dada por programas de reciclagem. Esta preocupação deve-se ao fato de que, graças ao aumento da adoção de soluções integradas de gerenciamento, estas técnicas têm sido empregadas simultaneamente. Conforme menciona Atkins [ATKINS.1993], quanto mais se recicla, mais a incineração se torna a solução apropriada para o resíduo restante. Este autor aponta que o programa mais intensivo de reciclagem pode retirar $75 \%$ do papel limpo, $80 \%$ do vidro, $50 \%$ dos metais e $40 \%$ dos plásticos e tecidos limpos. Esta retirada reduziria o poder calorífico global em apenas $16 \%{ }^{3}$ mas, objetivos mais realistas de reciclagem de materiais tem efeito nulo ou de acréscimo no poder calorífico. O resultado

\footnotetext{
${ }^{3}$ Considerando uma composição média do RSU na Europa
} 
de um estudo do efeito de diversos programas de reciclagem sobre o poder calorífico. realizado na Alemanha em 1990. é mostrado na figura 2.5 a seguir.

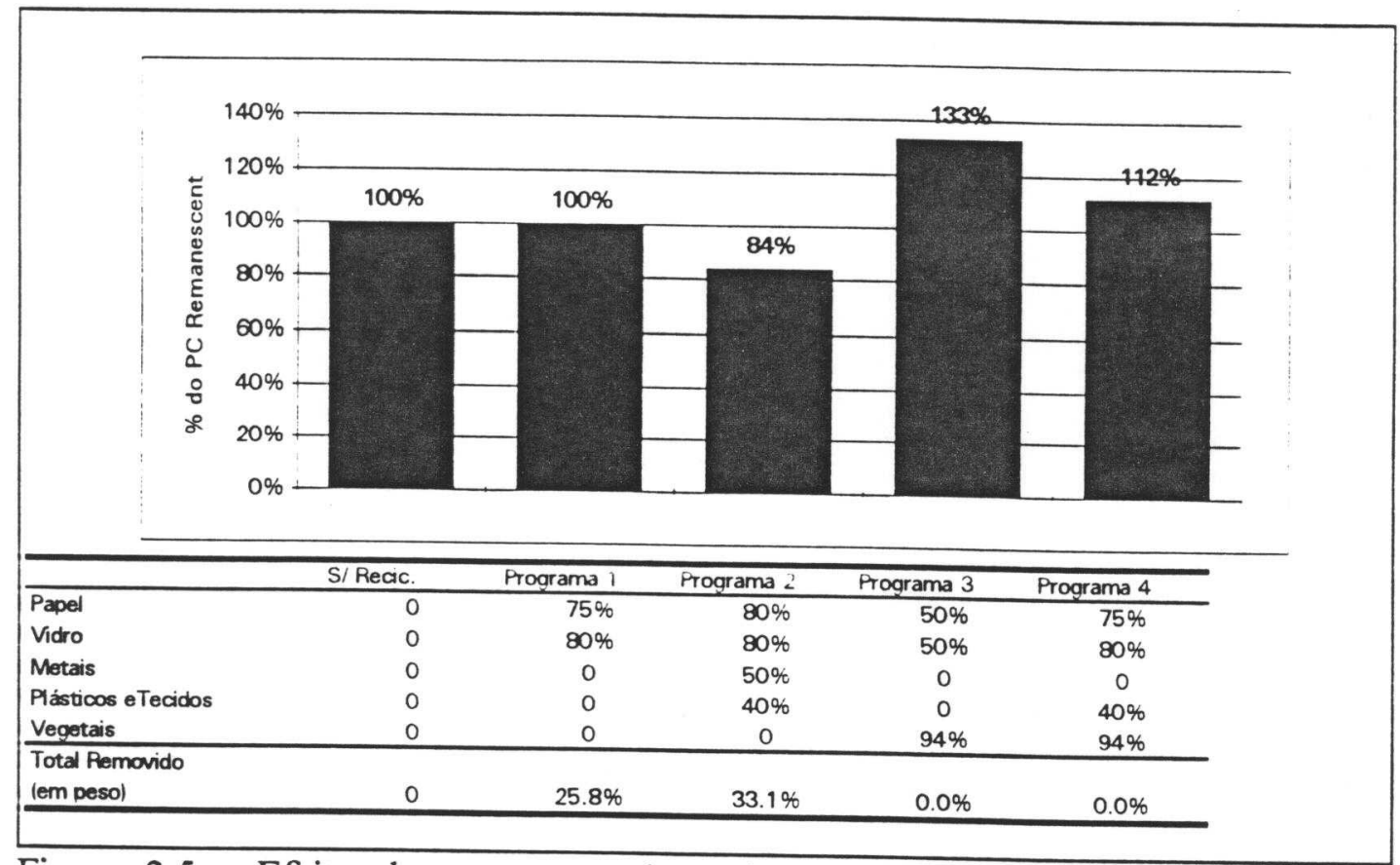

Figura 2.5 - Efeito de programas de reciclagem sobre o poder calorífico do lixo: Alemanha 1990.

Fonte: Atkins. 1993.

Apesar do reaproveitamento de energia não ser possível no caso da deposição em lixões, aterros controlados ou deposição no oceano. a deposição em aterros sanitários permite a coleta do gás gerado na decomposição dos resíduos através do bloqueio dos canais de ventilação instalados e da construção de um sistema de dutos para coleta. $\mathrm{O}$ processo de decomposição e o gás gerado são similares aos do processo de fermentação ou digestão anaeróbica, entretanto. volumes bem maiores podem ser gerados uma vez que não existe uma escala máxima para um aterro sanitário.

O uso de gás de aterro cresceu significativamente nos EUA durante a década de 80 principalmente devido às limitações impostas pela EPA quanto a emissões de gases em aterros. Estimava-se que em 1990 existiam 140 aterros com aproveitamento de gás para geração de energia elétrica nos EUA. a maior parte utilizando motores alternativos 
a gás natural modificados para queima do gás de aterro que possui baixo poder calorífico [COLLINS. 1990]. Entretanto. um ponto a considerar nesta opção, é o dificil controle do sistema de coleta e queima do gás. uma vez que o processo de decomposição ocorre a taxas naturais. não totalmente previsiveis. 


\section{CAPÍTULO 3}

\section{Resíduos Sólidos no ABCD}

Após a descrição dos RSU apresentada no capítulo anterior, será possivel a análise da questão dos resíduos sólidos urbanos na região do $\mathrm{ABCD}$. Esta questão não é recente, datando da década de 70 os primeiros estudos visando a solução dos problemas existentes. Desenvolve-se então um histórico do problema, descreve-se o sistema de coleta e destinação atual e encerra-se o capitulo com as alternativas de solução apresentadas aos municípios do $\mathrm{ABCD}$ pelo estudo mais recente.

\section{1- Histórico}

A história dos estudos sobre destinação de resíduos sólidos na região do $\mathrm{ABCD}$ coincide com os estudos desta questão para a região metropolitana de São Paulo. Em 1972, o GEGRAN - Grupo Executivo da Grande São Paulo, realizou estudo preliminar da questão da destinação dos resíduos sólidos na área metropolitana. Já neste período foi possível identificar a sub-região sudeste (Grande $\mathrm{ABCD}$ ) como uma das áreas críticas e, desta forma. foi encomendado um estudo mais completo sobre o problema na região. Este estudo foi realizado pela empresa SERETE Engenharia que elaborou relatório apontando as alternativas tecnológicas e locacionais disponíveis'. Foram levantadas 6 áreas disponíveis para construção de aterros. 12 para estações de transbordo, 6 para usinas de incineração e 2 para usinas de compostagem. Este estudo sugeria ainda que os municípios da região deveriam buscar soluções conjuntas uma vez que não existiam

\footnotetext{
${ }^{1}$ Para uma análise deste relatório ver EMPLASA. dez. 1975.
} 
áreas disponíveis em todos eles. Baseados em simulações para otimização dos investimentos, o trabalho concluiu pela proposição da seguinte alternativa:

- Utilização de somente aterros sanitários até 1980. (1 em Diadema e 2 em Santo André)

- Iniciar, em 1980, a construção de uma usina de compostagem de 100 t/dia em Diadema com uma estação de transbordo em Santo André.

- Iniciar, entre 1985 e 1990, a construção de uma usina de incineração de grande porte, com capacidade superior a $3.000 \mathrm{t} / \mathrm{dia}$.

Como resultado deste trabalho, os municipios da região se mobilizaram no intuito de constituir, em 1976, uma empresa regional para cuidar dos serviços de coleta, tratamento e destinação final do lixo. Devido a questões políticas esta iniciativa não chegou a se concretizar. Antes desta tentativa conjunta de todos os municípios da região, São Bernardo do Campo, São Caetano do Sul e Diadema haviam selecionado uma área no Bairro do Alvarenga em São Bernardo do Campo para deposição conjunta dos RSU. Neste local passaram a ser depositados a céu aberto. não só o lixo urbano, como também resíduos sólidos industriais e de serviços de saúde. É importante citar que já naquele ano, 1974, São Caetano e Diadema não dispunham de nenhuma área disponível para deposição de resíduos, e em particular, São Caetano que possui o perímetro urbano coincidente com a área do município.

Os outros municípios partiram então para soluções individuais: Santo André implantou um aterro sanitário na chamada Cidade São Jorge; em área indicada pelo trabalho da SERETE Engenharia: Mauá passou a utilizar um lixão localizado no Bairro do Sertãozinho: Ribeirão Pires continuou a depositar seu lixo em outro vazadouro a céu aberto (lixão) no distrito de Ouro Fino Paulista: e Rio Grande da Serra também possuia um vazadouro a céu aberto em sua área municipal.

A partir de 1976. diversas leis estaduais vieram a alterar significativamente o quadro existente na região a respeito da questão. Poderíamos dizer que, a partir deste 
ano, com a regulamentação de leis ambientais relativas às Áreas de Proteção de Mananciais $^{2}$. a situação na região passou de preocupante a emergencial. Estas leis proibem a instalação de qualquer sistema de tratamento e/ou disposição final de resíduos sólidos dentro de APM. Como já mencionado no item 1.3.3 desta dissertação, 56\% da área da região é considerada APM. Alguns dos dispositivos existentes na região apesar de irregulares em termos ambientais devido a sua operação, passaram também a serem considerados ilegais.

Entre 1979 e 1980, Santo André inaugurou uma usina de reciclagem e compostagem no Bairro Cidade São Jorge. Também a partir desta época, o aterro sanitário deste município passou a sofrer repúdio da população circunvizinha pois foi autorizada a construção de um conjunto habitacional junto ao mesmo.

Em 1983 a CETESB e EMPLASA elaboraram o Programa Emergencial para Disposição do Lixo Urbano na RMSP. Este estudo propunha a implantação, a curto prazo, de 13 aterros sanitários, individuais ou consorciados por dois ou mais municípios. Esta foi, na verdade, a primeira tentativa de uma solução integrada para toda a Região Metropolitana de São Paulo. A partir deste estudo, iniciaram-se a implantação de somente 4 aterros, sendo dois no Grande ABC (Santo André-ampliação, e Diadema). Neste estudo estavam ainda previstos mais 2 aterros na região, um em Mauá, no Bairro do Sertãozinho (recuperação do lixão existente), e outro em São Bernardo do Campo, nas proximidades do Parque Selecta.

No segundo semestre de 1986, o "Lixão do Alvarenga" (São Bernardo), que recebia os resíduos sólidos de Diadema, São Caetano e São Bernardo, foi fechado por decisão judicial onde os proprietários solicitavam reintegração de posse. Este lixão foi considerado o pior da região metropolitana, pois. recebia resíduos diversos (inclusive industriais e hospitalares), permitia a presença de centenas de catadores, criação de suínos e está localizado a menos de 200 metros da Represa Billings, descarregando nesta

\footnotetext{
${ }^{2}$ Lei Estadual 898 de 18/12/75 e Lei Estadual 1.172 de 17/11/76
} 
todo o chorume do vazadouro. Com o fechamento, os três municípios ficaram sem local de deposição buscando, cada um. uma solução individual.

São Bernardo conseguiu autorização temporária para deposição de Santo André, logo cancelada pela preocupação das autoridades e população local com a drástica redução da vida útil do aterro. Uma área localizada no Bairro do Montanhão foi descartada após pressão popular. Outra área. localizada no campo de treinamento do Tiro de Guerra, passou a ser utilizada por alguns dias até a interrupção por exigência da população que chegou a interditar as vias de acesso. Após acordos com a Prefeitura de Mauá, São Bernardo passou a enviar seus Resíduos Sólidos para aterro em Mauá.

O Municipio de Diadema sem conseguir um acordo para a deposição no Aterro dos Bandeirantes (do Municipio de São Paulo), impedido de depositar em seu antigo Lixão no Bairro da União. e no aterro controlado de Itapevi, teve que interromper a coleta regular de lixo em diversas ocasiões, uma vez que não existiam outras áreas disponiveis para uma deposição temporária. Após negociação com os proprietários do Lixão do Alvarenga, Diadema voltou a depositar seu lixo naquela área, fato que persiste até hoje causando grandes preocupações ambientais.

São Caetano por sua vez conseguiu autorização para deposição no aterro de Santo André. situação que também perdura até a presente data. O Município de Mauá passou a utilizar a área da antiga cava da Mineradora Lara após o início da deposição naquele local pelo Município de São Bernardo. O Município de Rio Grande da Serra passou a enviar os RSU para Mauá. Esta solução também foi adotada por Ribeirão Pires após ter frustada sua tentativa de recuperação da área do Lixão do Ouro Fino e a sua transformação em aterro sanitário.

Esta situação alarmante. e até desesperadora. dos Municípios do Grande $A B C$, motivou o reinicio dos trabalhos desenvolvidos pela EMPLASA. No início de 1987 a EMPLASA elaborou outro estudo com proposições para implementação imediata de aterros sanitários nas áreas críticas da RMSP.(EMPLASA, abril 1987). Logo a seguir, em 1988 outro estudo foi concluído numa tentativa de atualizar o Programa Emergencial 
de 1983. Esta reavaliação concluiu que dos 13 aterros propostos, 8 ainda apresentavam condições de viabilidade e 3 já estavam em processo de implantação. Um destes era a ampliação do aterro de Santo André em área contígüa à usina de compostagem e estava sendo implementado pela prefeitura local. Apesar da Secretaria de Negócios Metropolitanos do governo estadual ter estabelecido como meta imediata a implementação dos aterros restantes após apreciação deste relatório da EMPLASA, não houve alocação de recursos e estes 8 aterros não foram iniciados.

Como nenhuma solução foi iniciada pelo governo do estado no sentido de uma solução conjunta contemplando todos os municipios da RMSP. durante 1989 e 1990 diversos municípios recorreram à EMPLASA buscando apoio do Estado, conforme sugere a legislação. Desta forma. a Secretaria da Habitação e Desenvolvimento Urbano solicitou à EMPLASA a elaboração de um Programa de Intervenções Priorizadas. Este programa concluiu que as soluções propostas pelo Programa Emergencial de 1983 não mais poderiam resolver os problemas existentes. Foram realizadas propostas de recuperação de 6 lixões e a reabilitação de 2 aterros sanitários. Este trabalho não incluiu a região do $\mathrm{ABCD}$ entre as áreas priorizadas e restringiu-se à recuperação de aparatos existentes em outros pontos da RMSP. alem de sugerir a adoção de novas técnicas de gerenciamento dos RSU.

Cientes dos diversos problemas regionais e da urgência de alguns destes, os municípios do ABCD fundaram. ao final de 1990, o Consórcio Intermunicipal das Bacias do Alto Tamanduateí e Billings ${ }^{3}$ com o objetivo de "buscar soluções adequadas para os problemas comuns aos seus integrantes, incluindo a coleta, tratamento e disposição final dos resíduos sólidos". Este consórcio contratou então a empresa FILSAN Eng. e Serv. para a realização de um Plano de Alternativas para a solução do problema dos resíduos sólidos urbanos. (FILSAN,1992) Este estudo foi finalizado em 1992 e sugere diversas alternativas de solução para o problema. seja de forma individualizada ou consorciada dos municipios. O relatório dos trabalhos é extenso e não

\footnotetext{
${ }^{3} \mathrm{O}$ consórcio é hoje denominado Consórcio Intermunicipal Grande $\mathrm{ABC}$
} 
conclusivo, ie. deixa em aberto as inúmeras proposições efetuadas. O relatório engloba ainda a deposição de resíduos da área de saúde e industriais. Foram levantadas diversas áreas disponiveis para a instalação de terminais de transbordo, usinas de compostagem, usinas de incineração e aterros sanitários.

Após este trabalho, por desinteresse político e falta de apoio institucional do governo do estado. nenhuma providência foi tomada no sentido de uma análise mais profunda das opções ou do início da implementação das soluções. O caráter emergencial das soluções pode ser facilmente compreendido quando ressaltado como exemplo que o município com mais tempo para procurar uma solução é Santo André cujo aterro tem fim de vida útil estimado para 1996 ou 1997, dependendo da ampliação do horário de funcionamento da usina de compostagem de 2 para 3 turnos.

\section{2- Parâmetros Físicos}

Conforme afirmado no capítulo 2, a elaboração de qualquer plano de gerenciamento de resíduos sólidos deve iniciar com a determinação dos parâmetros físico-químicos. Esta análise permitirá avaliar a aplicabilidade de soluções de tratamento bem como prever os produtos resultantes deste tratamento.

Segundo dados levantados pela EMPLASA e mostrados na tabela 3.1, os 7 municípios da Região do $\mathrm{ABCD}$ coletam diariamente 1232 toneladas de resíduos sólidos. Esta quantidade representa aproximadamente $9 \%$ do total coletado na RMSP. É importante ressaltar que esta é a quantidade coletada, e não, gerada na região. Considerando que o serviço não atende toda a região, que existem serviços de coleta clandestina de resíduos do comércio e que existem diversas áreas de deposição clandestina, podemos inferir que a quantidade gerada de resíduos sólidos é bem maior do que a quantidade apresentada na tabela 3.1. 
Tabela 3.1- Coleta de domiciliar de Resíduos Sólidos (1991), segundo EMPLASA

\begin{tabular}{|c|c|c|c|c|}
\hline & \multicolumn{2}{|l|}{ Coleta } & \multirow{2}{*}{\begin{tabular}{|l|} 
Populaçăo \\
hab. 1991
\end{tabular}} & \multirow[b]{2}{*}{ kgjdia.hab } \\
\hline & tdia & $\%$ & & \\
\hline Diadema & 170 & $13.8 \%$ & 305.067 & 0.56 \\
\hline Mauá & 140 & $11.3 \%$ & 294.631 & 0.48 \\
\hline Ribeirão Pires & 35 & $2.8 \%$ & 85.035 & 0.41 \\
\hline Rio Grande da Serra & 12 & $1.0 \%$ & 29.848 & 0.40 \\
\hline Santo André & 315 & $25.6 \%$ & 615.112 & 0.51 \\
\hline São Bernardo do Campo & 400 & $32.5 \%$ & 556.003 & 0.72 \\
\hline São Caetano do Sul & 160 & $13.0 \%$ & 149.203 & 1.07 \\
\hline Região Sudeste SP(ABC) & 1232 & $100.0 \%$ & 2.034 .899 & 0.61 \\
\hline Municipio São Paulo & 10715 & $76.2 \%$ & 9.480 .427 & 1.13 \\
\hline Grande São Paulo & 14066 & $100.0 \%$ & 15.085 .394 & 0.93 \\
\hline
\end{tabular}

Fonte: EMPLASA.1992

Baseado nos números levantados pela FILSAN. elaborou-se a tabela 3.2 que mostra o potencial de coleta de resíduos sólidos na região caso o atendimento da coleta domiciliar passe a $100 \%$. O potencial estimado de coleta situa-se então próximo de 1800 toneladas diárias, que representa um número conservador, visto que não se incluiu os resíduos de coleta e deposição clandestinas. Analisando a coluna da geração per capita de resíduos, observa-se que os índices obtidos utilizando a coleta potencial se aproximam mais da média da Grande São Paulo e do índice obtido para o Município de São Paulo, ambos mostrados na tabela 3.1.

Tabela 3.2 -Atendimento dos serviços de Limpeza Urbana e coleta potencial no ABCD

\begin{tabular}{|l|lll|ll|l|}
\hline Município & \multicolumn{3}{|l|}{ Atendimento) } & \multicolumn{2}{l|}{ Coleta (em Vdia) } & Potencial/ Pop. \\
& Coleta & Varriça & Capma & Atual (91) & Potencial & kg/(hab.dia) \\
\hline Diadema & $65 \%$ & $64 \%$ & $64 \%$ & 181 & 278 & 0.91 \\
Mauá & $91 \%$ & $95 \%$ & $95 \%$ & 171 & 188 & 0.64 \\
Ribeirão Pires & $81 \%$ & $66 \%$ & $66 \%$ & 44 & 54 & 0.64 \\
Rio Grande da Serra & $54 \%$ & $54 \%$ & $54 \%$ & 12 & 22 & 0.74 \\
Santo André & $95 \%$ & $17 \%$ & $95 \%$ & 473 & 498 & 0.81 \\
São Bernardo do Campo & $74 \%$ & $95 \%$ & $95 \%$ & 433 & 585 & 1.05 \\
São Cactano do Sul & $98 \%$ & $100 \%$ & $100 \%$ & 169 & 172 & 1.16 \\
\hline
\end{tabular}

Obs: Elaboração do autor a partir de dados de FU.SAN 1992

1 Considerando somente at endimento de $100 \%$ na coleta.

As características físico-químicas disponiveis do RSU da região do $\mathrm{ABCD}$ estão sumarizadas na tabela 3.3 abaixo. Não existe uma total compatibilidade entre as medidas 
efetuadas nos dois estudos encontrados o que impede uma análise precisa no presente trabalho. A determinação completa e cuidadosa destes parâmetros é a primeira sugestão que deixa-se às autoridades envolvidas com a questão. Para os cálculos deste trabalho serão utilizados valores médios considerando que vieses importantes foram apontados na metodologia utilizada no trabalho da FILSAN.

Tabela 3.3 Parâmetros físico-químicos do RSU na região do $\mathrm{ABCD}$

\begin{tabular}{|c|c|c|}
\hline & SERETEI & FILSAN ${ }^{2}$ \\
\hline $\mathrm{pH}$ & n.d. & 6.6 \\
\hline Umidade & 61.6 & 59 \\
\hline Sólidos Volateis \% peso seco & 66.03 & 68 \\
\hline$\%$ peso seco & 33.97 & 32 \\
\hline Fósforo & 0.25 & $\begin{array}{c}0.42^{3} \\
(4225 \mu \mathrm{g} / \mathrm{g}) \\
\end{array}$ \\
\hline Potássio & 0.87 & $\begin{array}{c}0.52 \\
(5176 \mu \mathrm{g} / \mathrm{g}) \\
\end{array}$ \\
\hline Nitrogênio & 1.56 & $\begin{array}{c}0.68 \\
(6819 \mu \mathrm{mg} / \mathrm{g}) \\
\end{array}$ \\
\hline Carbono & 35.16 & 28 \\
\hline Enxofre & 0.17 & 0.4 \\
\hline Hidrogênio & 3.17 & n.d. \\
\hline Oxigênio & 45.09 & n.d. \\
\hline$(\mathrm{kcal} / \mathrm{kg})$ & $\begin{array}{c}3175 \\
(13271 \mathrm{~kJ} / \mathrm{kg}) \\
\end{array}$ & $\begin{array}{c}2965 \\
(12394 \mathrm{~kJ} / \mathrm{kg})\end{array}$ \\
\hline$(\mathrm{kcal} / \mathrm{kg})$ & n.d. & $\begin{array}{c}769 \\
(3214 \mathrm{~kJ} / \mathrm{kg})\end{array}$ \\
\hline Peso Especifico $\quad(\mathrm{Kg} / \mathrm{m} 3)$ & 205 & n.d. \\
\hline $\begin{array}{l}\text { Lixo compactado na coleta } \\
(\mathrm{kg} / \mathrm{m} 3)\end{array}$ & 400 & n.d. \\
\hline
\end{tabular}

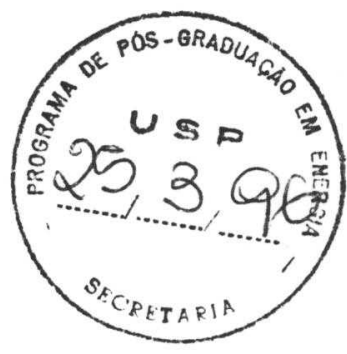

n.d. - não determmado

1. Fonte: SERETE. Estudo da solução Integrada para disposição tỉnal dos residuos sólidos da sub-região sudeste da área metropolitana da Grande São Paulo - Relatório Final. GEGRAN. São Paulo. Maio 1973

2. Fonte: Fonte FILSAN. 1992 Prod.5 Vol 2. pag 146

3. As altas concentraçôes de fosfato e umidade encontradas devem-se a possibilidade das amostras terem sido realizadas em dias de feira livre. principalmente em São Bernardo e Santo Andre onde extes mdices atingiram valores de $9000 \mu \mathrm{g} / \mathrm{g}$ e $3380 \mu \mathrm{g} / \mathrm{g}$. respectivamente.

\section{3- Sistema de coleta e destinação atual}

$\mathrm{O}$ atual sistema de coleta no $\mathrm{ABCD}$ atende em média a $80 \%$ das residências da região. Dos 7 municípios. somente em Rio Grande da Serra a coleta não é realizada por empresa particular sub-contratada. O serviço total na região é realizado por 77 caminhões transportando. cada um. uma média de 22 toneladas por dia. A média de 
viagens realizadas é de 3 por dia para cada caminhão entre o circuito de coleta e o local de descarregamento.A tabela 3.4 mostra os índices de atendimento dos serviços de limpeza pública e os executores por município da região.

Tabela 3.4 - Serviços de Limpeza Pública no ABCD e Executores

\begin{tabular}{|l|lll|ll|ll|}
\hline \multirow{2}{*}{ Diadema } & \multicolumn{3}{|l|}{ Coleta } & Varricão & \multicolumn{2}{l|}{ Capma } \\
\cline { 2 - 8 } & Atend. & Respons. & Alend. & Respons. & Atend. & Respons. \\
\cline { 2 - 8 } & $65 \%$ & INTRANSCOL & $64 \%$ & MTE AZUL & $64 \%$ & PREFEITURA \\
\hline Maua & $91 \%$ & SANURBAN & $95 \%$ & SANURBAN & $95 \%$ & SANURBAN \\
\hline Ribeirão Pires & $81 \%$ & SANURBAN & $66 \%$ & PREFEITURA & $66 \%$ & PREFEITURA \\
\hline $\begin{array}{l}\text { Rio Grande da } \\
\text { Serra }\end{array}$ & $54 \%$ & PREFEITURA & $54 \%$ & PREFEITURA & $54 \%$ & PREFEITURA \\
\hline Santo Andre & $95 \%$ & ENTERPA & $17 \%$ & PREFEITURA & $95 \%$ & PREFEITURA \\
\hline $\begin{array}{l}\text { São Bermardo do } \\
\text { Campo }\end{array}$ & $74 \%$ & $\begin{array}{l}\text { VEGA- } \\
\text { SOPAVE }\end{array}$ & $95 \%$ & VEGA-SOPAVE & $95 \%$ & PREFEITURA \\
\hline $\begin{array}{l}\text { São Caetano do } \\
\text { Sul }\end{array}$ & $98 \%$ & $\begin{array}{l}\text { VEGA- } \\
\text { SOPAVE }\end{array}$ & $100 \%$ & TRANSBRACAL & $100 \%$ & PREFEITURA \\
\hline
\end{tabular}

Fonte: FILSAN. 1992. (Produto 5. Vol.2.pag.85)

A coleta é realizada em dias alternados nos bairros e todos os dias no centro em quase a totalidade dos municípios. O Município de São Caetano tem coleta diária. A tabela 3.5 abaixo resume as despesas anuais com o serviço de limpeza urbana dos município e arrecadação correspondente à prestação deste serviço. A média ponderada dos custos apresentados é de US\$26 para coleta e transporte e de US\$ 14 para disposição final.

Tabela 3.5 Custos e Arrecadação dos Serviços de Limpeza pública no ABCD.

\begin{tabular}{|c|c|c|c|c|c|c|c|}
\hline Municipio & $\begin{array}{l}\text { Coleta } \\
\text { uransporte } \\
\text { US\$ } / 4\end{array}$ & $\begin{array}{l}\text { e Destimação } \\
\text { final } \\
\text { US\$ } \$\end{array}$ & $\begin{array}{l}\text { total } \\
\text { US\$ } \$\end{array}$ & $\begin{array}{l}\text { Coleta } \\
\text { total } \\
\text { t. }\end{array}$ & $\begin{array}{l}\text { Custo anual } \\
\text { US } \$(1992)\end{array}$ & $\begin{array}{l}\text { Arrecadação } \\
\text { destimada à } \\
\text { LP }\end{array}$ & Cobertura \\
\hline Municipio & (A) & (B) & $\begin{array}{l}U S \$ / t \\
(A)+(B)\end{array}$ & & US\$ (1992) & $\begin{array}{l}\mathrm{LP} \\
\text { (1991)US\$ }\end{array}$ & \\
\hline Diadema & 25.40 & 19.41 & 44.81 & 181 & 2538621 & 13161 & $0.5 \%$ \\
\hline Mauá & 28.03 & 17.25 & 45.28 & 171 & 2423521 & 226388 & $9.3 \%$ \\
\hline Ribeirão Pires & 34.42 & 12.36 & 46.78 & 44 & 644254 & 438061 & $68.0 \%$ \\
\hline Rio Grande da Serra & n.d. & n.d. & n.d. & 12 & n.d. & n.d. & \\
\hline Santo André & 25.83 & 10.04 & 35.87 & 473 & 5310518 & 5548272 & $104.5 \%$ \\
\hline São Bemardo do Camp̣o & 23.96 & 11.59 & 35.55 & 433 & 4818056 & 4124003 & $85.6 \%$ \\
\hline \multirow[t]{2}{*}{ São Caetano do Sul } & 32.12 & 26.59 & 58.71 & 169 & 3105583 & 1362089 & $43.9 \%$ \\
\hline & & & & Toxal & 18840553 & 11711974 & $62.2 \%$ \\
\hline
\end{tabular}

Fonte: FILSAN. 1992 (op.cit.. Prod.5. Vol.2.pag. 129)

Obs: 1 . O custo da destinação fimal em Santo André foi calculado pela ponderação dos cušnos de aterro (US\$6.21/t) e de compostagem (US\$12 $/$ ) utilizando-se os valores de $33.8 \%$ e $66.2 \%$ para aterro e compostagem. respectivamente.

2. A Prefeitura de São Caetamo paga uma taxa de administração de $100 \%$ para a disposição do lixo e usina de Santo André. justificando o valor de US $\$ 26$ para disposição tínal.

3. O valor de coleta do Municipio de Diadema não inclui os custos da prefeitura. o numero apresentado corresponde somente ao valor pago a Empreiteira. 
A tabela 3.6 apresenta as soluções adotadas e as características da destinação final na região do $\mathrm{ABCD}$. Os valores desta tabela foram retirados do relatório preliminar da EMPLASA (1992) e diferem dos valores encontrados no trabalho da FILSAN. Acredita-se que esta discrepância possa se originar em informações coletadas em orgãos distintos, das Prefeituras ou empreiteiras ou em critérios distintos de contabilização dos resíduos. Esta diferença é significativa. representando $250 \mathrm{t}$ /dia, quantidade equivalente à soma dos resíduos de São Caetano. Ribeirão Pires e Rio Grande da Serra. Conforme sugerido anteriormente, uma caracterização cuidadosa dos resíduos sólidos urbanos na região é necessária antes de estudos mais aprofundados de soluções e antes da tomada de qualquer decisão.

Considerando-se ainda os valores apresentados na tabela 3.6 , verifica-se que $14 \%$ dos resíduos coletados na região não recebem tratamento adequado. São 170 t/dia depositadas por Diadema no "Lixão do Alvarenga" localizado na divisa de São Bernardo e Diadema e a menos de 200 metros da Represa Billings. A deposição é realizada neste lixão pela alegação de falta de alternativa viável à destinação dos resíduos sólidos do Município. Observa-se também que Santo André e São Caetano possuem um programa oficial de reciclagem de residuos, realizado junto à usina de compostagem de Santo André, mas que ainda representam menos de $4 \%$ do total de resíduos coletados em toda a região. Considerando estes dois municipios somente, a reciclagem evita o envio ao aterro sanitário de $9.7 \%$ dos resíduos coletados.

$\mathrm{O}$ sistema atual de deposição encontra-se em vias de esgotamento. $\mathrm{O}$ aterro de Santo André, que recebe também os resíduos provenientes de São Caetano, tem fim de vida útil estimado entre fins de 1996 e meados de 1997. O aterro de Mauá, que recebe os resíduos de São Bernardo do Campo. Mauá. Ribeirão Pires e Rio Grande da Serra tem capacidade para mais 1 ano no máximo. ie. até meados de 1995 (FILSAN,op.cit). A situação do Município de Diadema é delicada uma vez que esta depositando em dispositivo ilegal e sujeita a interdição a qualquer momento. 
Tabela 3.6 Soluções Adotadas e Características das Áreas de Destinação Final na Região Sudeste da RMSP (1991)

\begin{tabular}{|c|c|c|c|c|c|c|c|c|c|c|c|c|c|c|c|c|}
\hline & \multirow{2}{*}{\multicolumn{8}{|c|}{ Soluçẵo (4) }} & \multirow{2}{*}{\multicolumn{3}{|c|}{ Propriedade Área }} & \multicolumn{3}{|c|}{ Distamcia da área a } & \multirow{2}{*}{\multicolumn{2}{|c|}{ IPM }} \\
\hline & & & & & & & & & & & & \multirow{2}{*}{$\begin{array}{l}\text { cuntro } \\
\text { cidade }\end{array}$} & \multicolumn{2}{|c|}{ Curso d'agua } & & \\
\hline & & II & III & IV & V & VI & VII & VIII & ref. & Part. & Dut. & & $200 \mathrm{~m}$ & $200 \mathrm{~m}$ & sim & Não \\
\hline Diadema & & 170 & & & & & & & & $x$ & & 8 & $x$ & & $x$ & \\
\hline Mauá & & & & & 140 & & & & & $x$ & & 5 & & & & $x$ \\
\hline Ribeirão l'ires (1) & & & & & 35 & & & & & * & & 14 & & & & $x$ \\
\hline Rio (irande da Serra (1) & & & & & 12 & & & & & * & & 20 & & & & * \\
\hline Santo André & & & & & 171 & 114 & & 30 & $x$ & & & p & & & & * \\
\hline São Bemardo do Campe(1) & & & & & 100 & & & & & * & & 12 & & & & $x^{*}$ \\
\hline Fão Cactano do Sul (2) & & & & & 80 & 64 & & 16 & * & & & 15 & & & & $F^{*}$ \\
\hline Região Sudeste SP & & 170 & & & 838 & 178 & & 16 & 1 & 1 & 1 & $12(3)$ & 1 & 1 & 1 & I \\
\hline irande São Paulo & 173 & 529 & 83 & 168 & 0582 & 1249 & 322 & 60 & 1 & 1 & I & & I & I & I & 1 \\
\hline
\end{tabular}

(1) Encia para at crro Mauá

(2) Linvia para atcro Santo André

(3) media

(4) Soluçãà

I- Simples Descearga a céu aberto (1.IXño)

II- Descarga a céu aberto com cobertura esporadica (LIXÃO)

III-I)escarga a céu aberto com equipamento permanente (L.IXÃO)

IV-Atero Centrolad

$V$ - Aterro Sanitári

VI- Compostagem

VIII-Reciclagen

VII-Incinctação

Baseado em EMPI ASA. 1992 


\section{4- Alternativas e perspectivas futuras}

As estimativas de crescimento populacional realizadas no item 1.4.2 indicam que, no ano 2010, entre 2.5 e 3,0 milhões de pessoas habitarão no $\mathrm{ABCD}$. Esta população gerará algo em torno de 2.100 toneladas diárias de resíduos sólidos urbanos segundo previsões da EMPLASA (1992, op.cit.). A destinação destes resíduos ainda é incerta visto que a região não dispõe de um plano estratégico de resíduos sólidos. Mesmo hoje, estes municípios possuem uma situação não definida claramente, alguns deles com riscos de ficar sem local de deposição por um simples ato jurídico ou legislativo visto que mais de 170 toneladas diárias são depositadas ilegalmente e outras 532 toneladas são depositadas em municípios distintos dos que geram sem existir uma garantia de continuidade do serviço. A região enfrenta então o problema da destinação atual e futura de seus resíduos.

As perspectivas de solução para o problema foram encomendadas à FLSAN Engenharia pelo Consórcio Intermunicipal Grande ABC. Apresenta-se a seguir um resumo das principais soluções propostas neste estudo que se encontra à disposição na sede do Consórcio. O mapa de localização das áreas estudadas encontra-se em apêndice. Neste mapa estão localizados os dispositivos existentes e as áreas correspondentes aos dispositivos propostos. Foram propostas, no Relatório Final (Produto 5), uma série de alternativas para solução isolada ou conjunta. Foi recomendado ainda que, até a implantação da alternativa escolhida. as seguintes providências deveriam ser tomadas:

- Ampliação do aterro sanitário de Santo André e interrupção da ocupação urbana no entorno do aterro.

- Ampliação do aterro utilizado por São Bernardo. Mauá, Ribeirão Pires e Rio Grande da Serra em caráter urgente visto que a vida útil deste aterro esgotaria-se em 1,5 anos (menos de 1 ano atualmente).

Entre as soluções propostas. foi sugerida como preferencial, uma articulação do Municipio de Diadema com São Bernardo do Campo no sentido da implantação conjunta 
de uma usina de reciclagem e compostagem na área AR-3 e um aterro sanitário na área AR-8. Da mesma forma, sugere-se uma solução conjunta de São Caetano do Sul com Santo André através da ampliação da usina de Reciclagem e Compostagem além da expansão já mencionada do aterro existente. Esta medida tem vida útil de apenas 9 anos indicando a necessidade de se iniciar a seleção de outra área para aterro. Para os municípios de Ribeirão Pires e Rio Grande da Serra, ambos inseridos 100\% dentro da PM, o estudo sugeriu a continuidade da deposição no aterro de Mauá. A vida útil média das soluções propostas, segundo o estudo, é de 20 anos. Entretanto, foram encontradas incongruências nas tabelas de soluções apresentadas e este número deve ser revisto em um estudo mais aprofundado das alternativas.

Foi apresentada também a opção de uma solução integrada de todo a região do $\mathrm{ABCD}$ através da criação de uma central de tratamentos de resíduos, anexo a um aterro e a construção de estações de transbordo.em pontos estratégicos dos municípios. Duas áreas foram selecionadas para implantação da central (incineração, compostagem, reciclagem) : AR-2, em Santo André e o conjunto de áreas vizinhas à área AS-3 em Mauá. Esta central seria dimensionada para uma capacidade nominal de 3500 toneladas diárias. Os valores de investimento apresentados no relatório não possuem detalhamento e, também aqui. encontrou-se alguns vieses que impedem a adoção destes valores. $\mathrm{Na}$ tabela 3.7 apresenta-se alguns dados das principais áreas selecionadas pelo estudo. É importante mencionar que, apesar de sugerido o uso para estas áreas, elas poderão não se tornar disponiveis por pressão da população, como já ocorreu inclusive na área AS-2 (Cata Preta), ou por impedimento levantado no Estudo de Impacto Ambiental.

Nas figuras 1.1, 1.2 e 1.3 (capitulo 1) já foram apresentadas as principais restrições (ambientais, populacionais e legais) para a instalação de aterros dentro da RMSP. A partir da combinação destas restrições pode-se determinar áreas onde potencialmente poderiam ser instalados aterros sanitários na busca de uma solução conjunta de toda a RMSP. Algumas destas áreas já possuem utilização produtiva ou mesmo são as áreas onde existem aterros e lixões em funcionamento. A investigação 
detalhada das disponibilidades futuras está sendo levantada pela EMPLASA em trabalho a ser divulgado brevemente.

Tabela 3.7 - Características de Áreas de Interesse para Destinação de RSU no ABCD

\begin{tabular}{|c|c|c|c|c|c|}
\hline Area & Municipio & $\begin{array}{l}\text { Area } \\
\mathrm{m}^{2}\end{array}$ & $\begin{array}{l}\text { Precn } \\
\text { em mil US\$ }\end{array}$ & $\begin{array}{l}\text { Camacidade } \\
\mathrm{m}^{3}\end{array}$ & Uso \\
\hline AS-1 (ampliação) & Sto. Andre & 193119 & 1582 & 2067000 & aterro \\
\hline AS-2 (Tiro de Guerra) & S.Bemardo & 207339 & 162 & 1725590 & aterro \\
\hline AR-8 & Diadema & 464500 & 1858 & 5000000 & aterro \\
\hline AR-2 (Cata Preta) & Sto. André & 890316 & 7301 & 4750000 & Central \\
\hline AS-3, AR-22. AS-4 & Mauá & 146665 & 373 & 7890000 & aterro \\
\hline $\begin{array}{l}\text { Mimeraçao Lara } \\
\text { AR-11 (Petrobras) }\end{array}$ & Mauá & 3585400 & 89380 & & Central \\
\hline $\begin{array}{l}\text { AI-1 AR-13 AR-23. AR- } \\
\text { 26AR26A }\end{array}$ & Mauá & 334932 & 752 & & Central \\
\hline
\end{tabular}

Fonte: FILSAN. 1992 (op.cit. Produto 5. vol.3)

O trabalho efetuado pela FILSAN traz ainda um grande número de opções combinando as diversas formas de tratamento para municípios isolados ou associados. A descrição de todas seria por demais extẹnsiva para ser incluida aqui. É interessante ressaltar que a implantação de um incinerador aparece em grande parte das soluções propostas. Apesar deste estudo trazer valores dos possiveis investimentos, não é realizado o detalhamento destes investimentos o que sugere certa cautela na utilização destes valores na comparação das alternativas. Esta comparação depende de uma descrição das diversas opções tecnológicas. desempenho esperado. impactos sociais e econômicos além de cronogramas físicos e financeiros. Acredita-se que a opção mais adequada para a região será a implantação de um Plano de Gerenciamento Integrado de Resíduos Sólidos, contemplando um "mix" de soluções entre: programas de redução, reciclagem. compostagem, incineração e aterro. A determinação da importância da incineração neste "mix" deve ser realizada de forma criteriosa buscando a minimização dos custos para as municipalidades. dos impactos ambientais e atingindo o ponto de consenso politico na região. Uma solução com estes requisitos terá grande chance de sucesso e certamente catalisará soluções para outros problemas comuns.

No próximo capitulo. descreve-se as tecnologias de incineração. Esta descrição permitirá o conhecimento do processo. das diversas variantes tecnológicas e seus 
detentores. Este é um procedimento que deverá ser seguido para cada uma das tecnologias de tratamento e disposição dos residuos na busca da solução que melhor se adeqüe ao $\mathrm{ABCD}$. Após esta descrição será possivel realizar o estudo de viabilidade de uma usina de inciração de resíduos sólidos urbanos. o que é realizado no capítulo 6. 


\section{Capítulo 4}

\section{Tecnologias de Incineração}

O primeiro incinerador de resíduos sólidos urbanos entrou em operação na Inglaterra em 1875. Desde então o seu projeto foi evoluindo na busca de uma melhor eficiência na destruiçâo dos resíduos e na minimização da emissão de poluentes. Nesta evolução surgiram diversas variantes tecnológicas, algumas com sucesso e outras destinadas ao fracasso. Durante a década de 1980 experimentou-se uma proliferação novas tecnologias e, consequentemente, de empresas fornecedoras. Existem hoje dezenas de fornecedores independentés no mundo e milhares de usinas em funcionamento. A tabela 4.1 ilustra o estado da arte de incineração em alguns países selecionados. É interessante notar o alto percentual de incineração em alguns países e a importância da recuperação de energia.

Tabela 4.1- Inicineração de Resíduos: Penetração em países selecionados

\begin{tabular}{|c|c|c|c|c|c|}
\hline Pais & $\begin{array}{l}\text { População } \\
\text { milhões de hab. }\end{array}$ & $\begin{array}{l}\text { No. de usinas de } \\
\text { Incineração }\end{array}$ & $\begin{array}{l}\text { Quantidade } \\
\text { mcinerada } \\
10^{6} \text { t/ano }\end{array}$ & $\begin{array}{l}\text { Percentual do } \\
\text { RSU }\end{array}$ & $\begin{array}{l}\text { Recuperação de } \\
\text { Energia }\end{array}$ \\
\hline Suecia & 8.6 & 23 & 1.8 & $55 \%$ & $100 \%$ \\
\hline Dinamarca & 5.2 & 38 & 1.7 & $65 \%$ & $100 \%$ \\
\hline Holanda & 14.9 & 12 & 2.8 & $40 \%$ & $50 \%$ das usinas \\
\hline Franca & 55.8 & 170 & 7.6 & $42 \%$ & $68 \%$ da capac. \\
\hline Espanha & 39.8 & 22 & 0.7 & $6 \%$ & 5 usinas \\
\hline Italia & 57.6 & 94 & 2.7 & $18 \%$ & $30 \%$ da capac. \\
\hline Remo Unido & 57.1 & 34 & 1.3 & $11 \%$ & $25 \%$ da capac. \\
\hline Hungria & 10.6 & 1 & 0.3 & $9 \%$ & não \\
\hline EUA & 248.3 & 168 & 28.6 & $16 \%$ & 128 usinas \\
\hline Japao & 123.2 & 1893 & 32 & $72 \%$ & poucas \\
\hline Canada & 23.1 & 17 & 1.7 & - & - \\
\hline
\end{tabular}


Concomitantemente à citada proliferação de tecnologias e fabricantes, aumentouse o rigor da legislação ambiental em praticamente todos os paises do mundo. Este fato gerou grande impacto na indústria de incineração forçando o aprimoramento das tecnologias de incineração e controle ambiental e determinando o abandono de outras.

$\mathrm{O}$ auge do citado "boom" ocorreu aproximadamente no final da década com um esfriamento do mercado a partir de então. Este "esfriamento" não deve ser entendido como uma tendência ao abandono da adoção desta alternativa. e sim em um natural retrocesso após um período de crescimento exagerado. Muitos fabricantes descontinuaram suas atividades e tecnologias foram abandonadas. $\mathrm{O}$ motivo principal destes fracassos (algumas vezes gerando prejuizos de ate US\$250 milhões às municipalidades compradoras) foi a adaptação à incineração de RSU de tecnologias ou projetos destinados a outros usos [CHILTON,1993]. Outro motivo levantado em um estudo por Chilton, deve-se à escolha de tecnologias que prometiam recuperação de metais e outros materiais antes da fabricação do combustível derivado de resíduo (RDF) para venda em um "promissor" mercado de reciclados. Não houve a reação esperada da industria para absorção do volume gerado de reciclados e os preços não atingiram os valores esperados determinando o fracasso dos empreendimentos. Finalmente, segundo Chilton, um outro grupo de projetos não obteve sucesso pela inexperiência no negócio de resíduos; empresas vencedoras em concorrências subestimaram seus custos. superestimaram os rendimentos com venda de energia e quantidade de resíduos disponiveis para queima. Isto causou um excesso de capacidade instaladada com as conseqüentes interrupções de projetos, fechamento de usinas e situações bizarras como um município pagando uma taxa maior de incineração em seu próprio incinerador do que municípios vizinhos graças a contratos de longo prazo firmados à epoca da construção[BAIlLEY, 1993].

Nos últimos anos. com a tendência já descrita do uso do conceito de gerenciamento integrado de resíduos. a incineração de resíduos sólidos tem se firmado como uma importante componente no processo. As novas usinas são capazes de atender 
aos rigorosos padrões de emissões dos países industrializados e apresentam fatores de disponibilidade superiores a $90 \%$ demonstrando a maturidade atingida pela tecnologia. Atkins [ATKINS, 1993] exemplifica mostrando que, apesar do ambicioso programa de reciclagem alemão, o qual pretende reciclar mais de $80 \%$ das embalagens em 1996, espera-se que ainda sejam construidas 25 a 50 usinas de incineração com recuperação de energia na Alemanha.

Descreve-se neste capítulo, as principais tecnologias disponíveis para incineração de RSU e alguns dos componentes básicos de uma usina. Esta descrição permitirá o conhecimento das diversas dos principais sistemas encontrados na literatura e nos catálogos de fabricantes aos quais foi possivel o acesso. A descrição exaustiva de todas as tecnologias exigiria o contato com todos os detentores destas tecnologias, o que iria além dos objetivos desta dissertação. O universo coberto abrange a quase totalidade das tecnologias utilizadas nos últimos anos em usinas de grande porte de incineração de resíduos sólidos urbanos. Após esta descrição será realizado um resumo das características de emissões atmosféricas de um incinerador e seus dispositivos de controle.

\section{1- Classificação}

Os sistemas de incineração de resíduos sólidos podem ser classificados segundo o modo de queima e segundo o formato da câmara de combustão. O modo de queima diz respeito a sequência das reações de combustão ou de neutralização dos compostos do lixo. Assim é possível classificar estes incineradores em:

- De ar sub-estequiométrico ou pirolíticos;

- De excesso de ar ou convencionais:

- De destruição quimica ou sem chama.

Os incineradores com fornecimento de ar sub-estequiométrico são aqueles usualmente classificados como pirolíticos. Esta denominção. indicativa da ocorrência de 
uma reação de pirólise. não é tecnicamente correta uma vez que. na prática, é extremamente dificil impedir a entrada de ar na câmara de combustão. Sendo assim ocorrem reações simultâneas de pirólise e combustão sendo fornecido ar à câmara de pirólise de uma forma controlada.

Os incineradores de resíduos sólidos ditos convencionais são aqueles onde é permitida a queima completa em uma só câmara. $\mathrm{O}$ ar necessário à queima é fornecido em quantidades que excedem à quantidade estequiométrica garantindo assim uma queima completa de todos os resíduos. É possível controlar esta queima variando o tempo de residência dos residuos na câmara de combustão.

Os incineradores de destruição química são aqueles onde. apesar de ocorrerem reações de oxidação (ou redução). não existe a formação de chama. Para resíduos sólidos existe atualmente somente uma tecnologia desenvolvida, a de Sal Fundido desenvolvido pela empresa Atomics International principalmente para queima de resíduos radioativos. A figura 4.1 mostra o esquema deste processo.

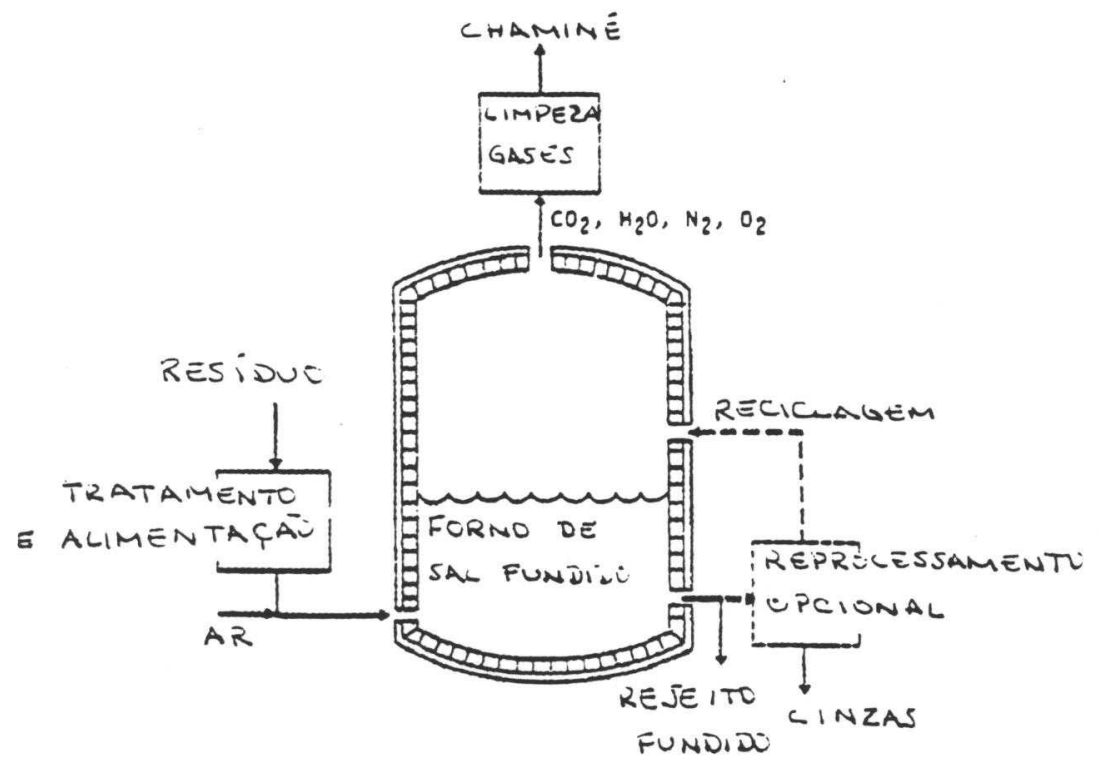

Figura 4.1 - Reator de Sal Fundido

Quanto à forma de entrada do resíduo. os incineradores podem ser de queima do resíduo bruto ("mass-burn") ou de combustivel derivado de resíduo ("refuse derived fuel -RDF"). A primeira opção representa a tendência atual (compreendendo $80,7 \%$ das 
usinas em planejamento nos EUA) principalmente por dispensar a preparação do resíduo após o recebimento na usina. Isto implica em investimento inicial menor e menores despesas com operação e manutenção.

Segundo o formato da câmara e processo de combustão os sistemas utilizados para incineração centralizada de resíduos sólidos urbanos podem ser classificados em:

- De forno calcinador ou rotatórios

- De grelha mecânica

- de movimento alternativo

- rolante

- Mistos

- De leito fluidizado

- Borbulhante

- Circulante

Os fornos calcinadores ou rotatórios são de uso bastante comum para queima de resíduos industriais perigosos e são bastante flexíveis permitindo a incineração conjunta com resíduos líquidos ou gasosos. Permite ainda a alimentação de resíduos em containers ou tambores que são lançados inteiros dentro do incinerador.

Os fornos de grelha mecânica possuem um sistema de elementos móveis que conduz os resíduos através da câmara de combustão. $\mathrm{O}$ ar primário é fornecido através da grelha evitando que esta seja danificada pela alta temperatura e restante do ar para combustão completa é fornecido diretamente na região de queima.

Os incineradores podem ainda possuir uma combinação destas duas formas anteriores. Nestes incineradores as grelhas usualmente antecedem ao forno rotativo. Uma descrição detalhada dos sistemas de grelha será apresentada no item seguinte. No atual estado da arte as tecnologias de grelhas mecânicas são as que mais se adeqüam à incineração centralizada de RSU nas quantidades geradas na região de interesse deste trabalho.

A tecnologia de combustão em leito fluidizado foi desenvolvida pela Exxon durante a II Guerra Mundial e vem sendo aprimorada nos últimos anos permitindo a queima de diferentes tipos de residuos. Entretanto os sistemas existentes são aplicáveis 
somente a sistemas de pequena e média escala $(<500 \mathrm{t} / \mathrm{dia})$.

A fluidização é a suspensão de material num fluxo de gás ascendente. Uma pequena quantidade de combustivel é misturada a quantidades razoáveis de material inerte a altas temperaturas promovendo então a queima. Os materiais inertes mais utilizados são areia. cinzas de combustão. calcáreo ou uma combinação deles. (HUKAI, 1991)

Existem dois tipos de incineradores de leito fluidizado: Leito Fluidizado Borbulhante (LFB) e Leito Fluidizado Circulante (LFC). Os incineradores de leito circulante são os de maior interesse na incineração de resíduos sólidos urbanos, diferenciando dos primeiros pela velocidade de recirculação do leito. Os combustores LFC podem queimar combustíveis múltiplos. líquidos ou sólidos. $\mathrm{O}$ esquema de um combustor deste tipo é ilustrado na figura 4.2.

As principais vantagens de combustão em leito fluidizado são: [HUKAI,1991 e EBARA,s.d.]

- Combustão mais eficiente devido à turbulência em que se encontra a mistura (combustível. material do leito e ar) e da elevada inércia térmica do leito propriciando secagem quase que instantânea dos residuos;

- Baixa formação de $\mathrm{SOx}$ e de ácidos $(\mathrm{HF}, \mathrm{HCl})$ pela neutralização propiciada pelo próprio leito;

- Reduzidas partes móveis diminuindo a manutenção por desgaste ou quebra de partes móveis;

Uma das desvantagens desta alternativa é a necessidade de pré-tratamento dos resíduos para retirada de metais, vidros, etc, o que aumenta o investimento e os custos de operação e manutenção. ${ }^{3}$

Nesta dissertação considerou-se somente a hipótese de uma solução conjunta dos municípios, a que implica em quantidades de resíduos que ultrapassam a aplicabilidade de usinas de leito fluidizado. Esta opção pode ser adequada para o tratamento dos RSU

\footnotetext{
${ }^{3}$ Este pre-tratamento é dispensado no reator "TIF" da EBARA.
} 
de municipios isolados no $\mathrm{ABCD}$ e um estudo mais aprofundado desta tecnologia deve ser realizado neste caso.

As classificações colocadas acima permitem uma generalização dos sistemas encontrados na prática. Estes sistemas possuem características especificas de acordo com o detentor da tecnologia. uma vez que são sistemas proprietários e bastante sofisticados. As adaptações introduzidas em cada tipo visam principalmente o aumento da eficiência de queima e melhor controle das emissões de poluentes.

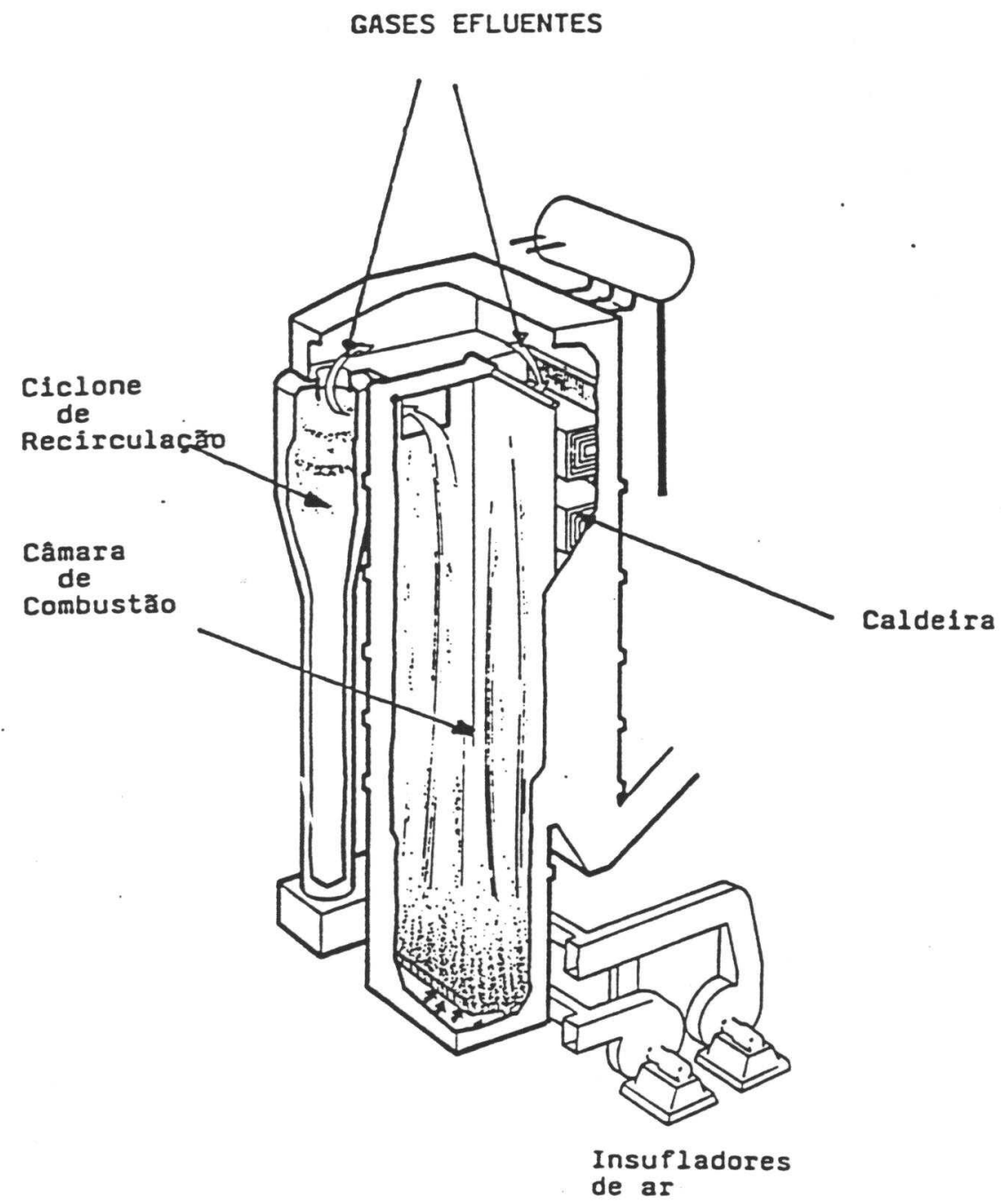

Figura 4.2 - Caldeira e combustor de Leito Fluidizado Circulante mostrando-se os gases de exaustão alimentando a caldeira 


\section{2 - Descrição geral de um sistema de incineração}

O esquema colocado na figura 4.3 mostra os componentes principais de um sistema de incineração e a figura 4.4 ilustra uma usina completa do tipo de grelhas rolantes. A câmara de reação representa a câmara de combustão, simples ou de duplo estágio, como nos incineradores do tipo pirolíticos. ou ainda pode representar um reator dos sistemas de neutralização quimica e nos incineradores de leito fluidizado. O sistema de recuperação de calor é opcional. No caso da não existência deste, um sistema de resfriamento é necessário para evitar danos aos sistema de tratamento de gases.

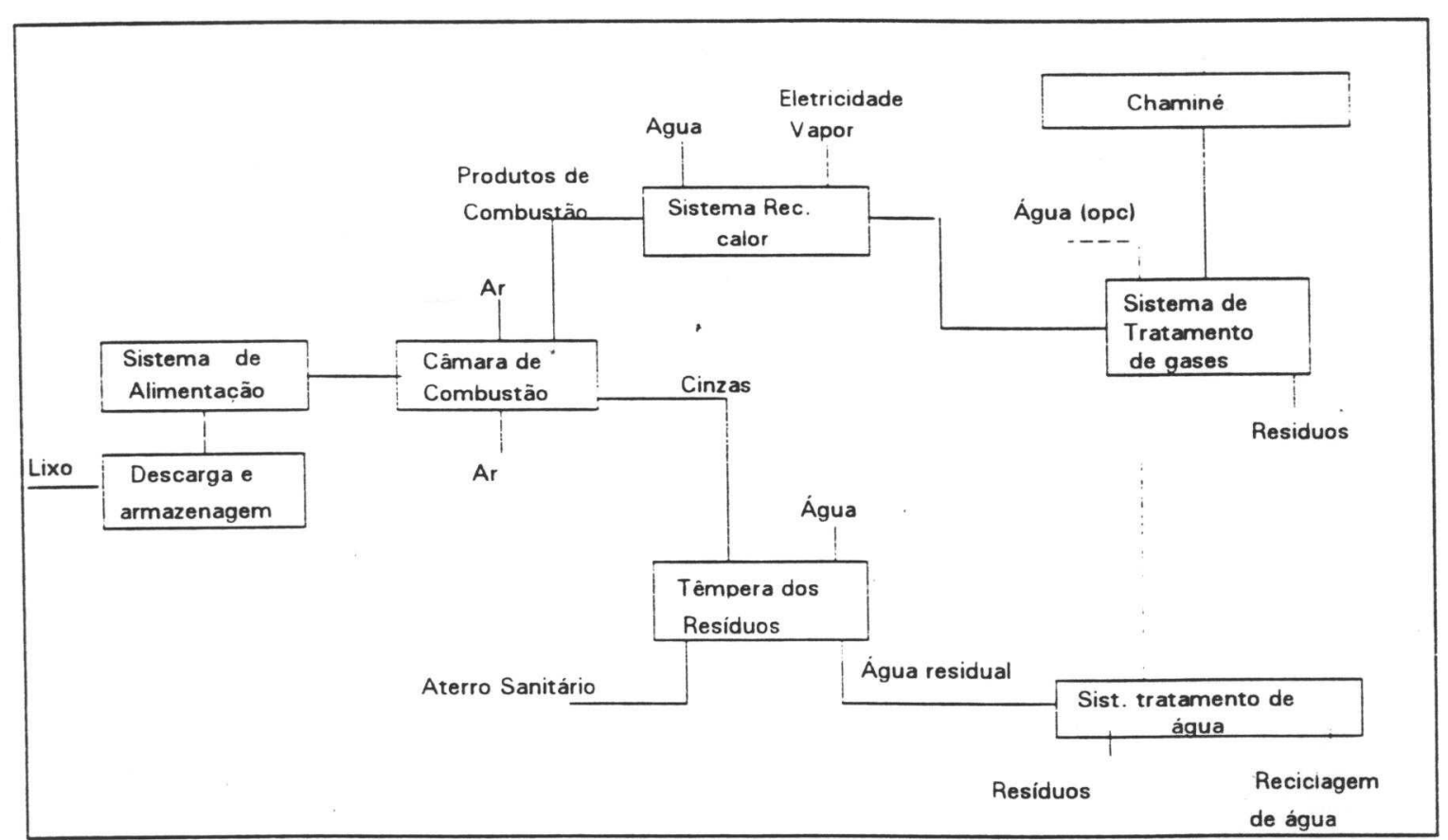

Figura 4.3 - Esquema típico de uma usina de incineração de resíduos sólidos Adaptado de: Steven, 1989.

O resíduo sólido. lixo. entra na usina em caminhões que são pesados à porta da usina para fins de controle e faturamento. O pátio de descarga usualmente faz parte do prédio da usina e é mantido sob pressão ligeiramente negativa impedindo que haja escape de odores para as redondezas. Esta diferença de pressão é obtida coletando o ar de combustão através deste prédio. Os caminhões descarregam em um fosso de armazenagem dimensionado para atender a demanda de combustivel da usina durante alguns dias na eventualidade de uma interrupção dos serviços de coleta. 
O lixo depositado no fosso é retirado por garras operadas em uma ponte rolante e colocado em tremonhas (funis) de alimentação da câmara de combustão. Quando não está alimentando as tremonhas. o operador da garra revira o lixo de forma a homogeneizar as diversas cargas recebidas e retirar elementos de grande volume.

A combustão do lixo gera dois fluxos de resíduos: resíduos gasosos, que contêm os produtos da combustão mais uma parcela de partículas sólidas em suspensão, e os resíduos sólidos, ou cinzas que contêm a parcela não combustível do lixo. Tanto os gases efluentes quanto as cinzas saem da câmara de combustão a temperaturas elevadas necessitando que sejam resfriados para tratamento posterior. No caso dos gases. estes podem ou não passar por um sistema de recuperação de calor antes do tratamento para retirada de elementos poluidores da atmosfera. As cinzas são resfriadas ao sair do forno e são então encaminhadas a aterros sanitários ou a sistemas especiais de recuperação de materiais. $\mathrm{O}$ resíduo destes processos é um material inerte com aparência vítrea que tem sido utilizado em alguns paises como base de pavimentação. Caso não haja nenhum tratamento posterior das cinzas. estas devem ser analisadas antes de serem encaminhadas a um aterro sanitário.

O sistema de recuperação de calor usualmente é composto por trocadores de calor que retiram energia térmica dos gases para pré-aquecimento do ar de combustão e geração de vapor. O vapor gerado pode ser comercializado diretamente nesta forma, na forma de água quente a alta pressão, ou ainda na forma de eletricidade após expansão em um conjunto turbina-gerador. A venda de energia gera receitas que possibilitam a redução da taxa de incineração do lixo, mas somente se torna viável atualmente em usinas de grande porte.

Após passar pelo sistema de recuperação de calor (ou por um sistema de resfriamento sem recuperação de calor) os gases são conduzidos a um sistema de tratamento dimensionado para reduzir as emissões de poluentes a padrões préestabelecidos e são finalmente lançados na atmosfera por uma chaminé.

O sistema de tratamento de água existe para recuperar parte da água empregada 
no resfriamento das cinzas e no sistema de limpeza dos gases. Nos processos modernos, a emissão de efluentes líquidos é nula ("zero discharge systems").

Nos sub-items seguintes procuraremos descrever os sistemas de combustão, recuperação de calor e tratamento de gases descritos genericamente acima, juntamente com os esquemas empregados pelos principais detentores de tecnologia.

1. Calpão de entrada

2. Depósito de lixo

3. Tremonha

4. Sistema de queima de grelha

rolante/fluxo paralelo

5. Extrator de cinza

6. Depósito de cinza

7. Caldeira

8. Secador por aspersão

9. Precipitador eletrostático

10. Ventilador

11. Lavador, 12 eatágio

12. Lavador, 28 eacégio

13. Chaminé

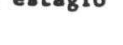

eacasio

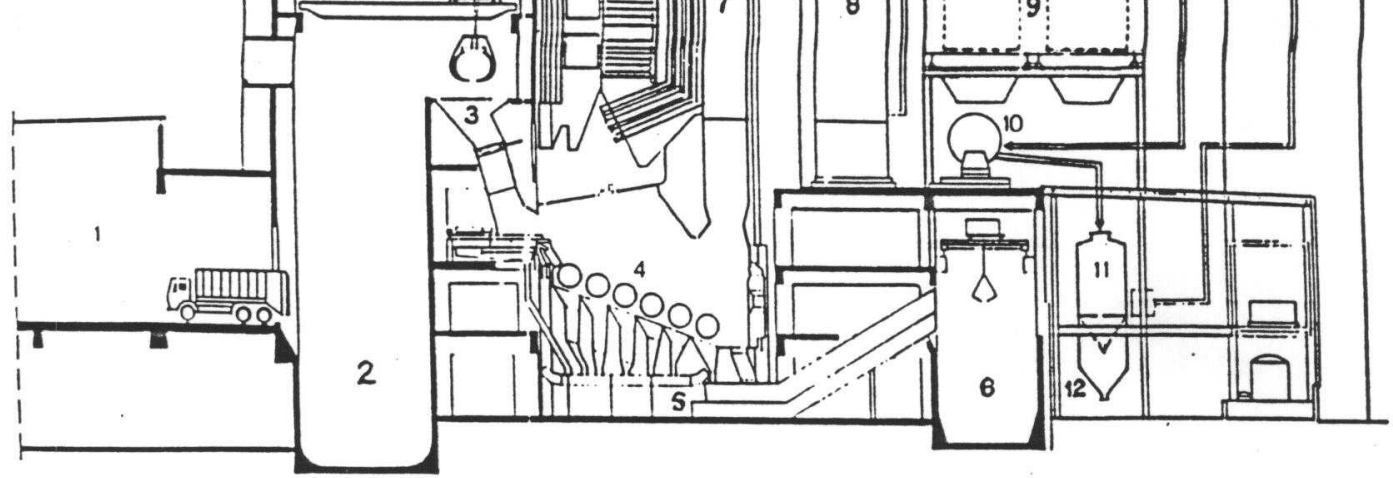

Figura 4.4 - Seção Longitudinal de uma usina de incineração

\subsection{Sistemas de Grelhas Mecânicas}

Os sistemas de grelhas mecânicas predominam nas usinas de grande porte de incineração de RSU. Esta concepção é a mais antiga e evoluiu a partir das grelhas de 
queima de carvão. Através de construção modular podem se construídas usinas com capacidade superior a 3000 tpd. Por possuirem um conceito construtivo mais antigo do que os outros sistemas apresentados no item anterior, estes sistemas apresentam ainda uma excelente confiabilidade.

A grelha é a parte da usina que é mais prejudicada pela heterogeneidade e pela composição imprevisível do lixo. O projeto correto é fundamental para garantir uma combustão eficiente, reduzidos niveis de emissão de poluentes atmosféricos e uma alta disponibilidade da usina. As funções da grelha são:

- dar suporte ao resíduo dentro da câmara de combustão;

- permitir injeção do ar primário por baixo do resíduo;

- transportar o resíduo do alimentador ao tanque de cinzas;

- agitar o leito (de resíduos) de forma a trazer carga não queimada à superfície.

A figura 4.5 , colocada a seguir, mostra, esquematicamente, como se processa a queima dentro da câmara de combustão. É possível definir três zonas na grelha a partir do ponto de entrada dos resíduos. Na primeira zona ocorre principalmente o processo de secagem, vaporizando-se a água presente no lixo. A zona seguinte é zona onde ocorrem reações de pirólise e gaseificação; e na terceira zona ocorre a queima total dos elementos volumosos ou de dificil queima. Acima destas duas últimas regiões se forma a chama devido às altas temperaturas desenvolvidas. $\mathrm{O}$ ar primário, injetado por baixo da grelha, é o principal responsável pelos processos ocorridos nas duas primeiras zonas. $\mathrm{O}$ ar secundário, injetado sobre o leito de resíduos, é responsável pelo controle da temperatura e garantia da combustão completa. Usualmente a proporção entre o ar primário e o ar secundário varia entre 40 a $60 \%$ do ar utilizado no incinerador [BRUNNER. 1991].

Dada a sua importância para o desempenho global da usina, a grelha é o principal item de diferenciação entre as tecnologias utilizadas pelos fabricantes. Procuramos descrever abaixo as principais tecnologias atualmente empregadas iniciando por aquelas que podem ser descritas de uma forma genérica. sendo comuns a mais de um fabricante. 


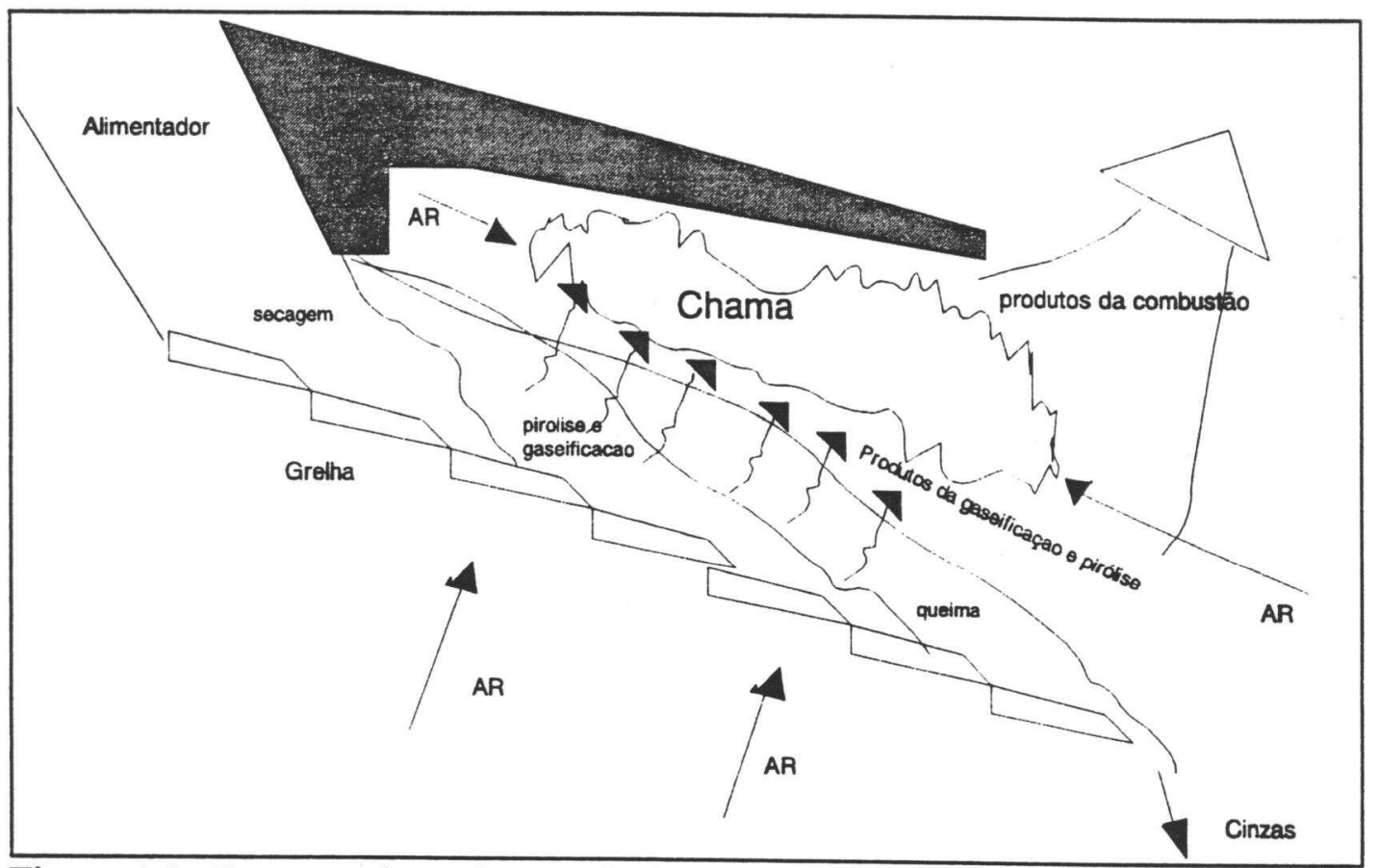

Figura 4.5 - Processo de queima em incinerador de câmara simples e grelha inclinada adaptado de: SAROFIM, 1977.

\section{Grelhas de elementos saltantes ("rocking grates")}

Como mostrado na figura 4.6 a seguir, este tipo de grelha é composto por elementos pivotantes que sobem e descem alternadamente agitando e avançando o lixo.

\section{Grelhas de atiçamento linear ("reciprocrating grates")}

Este tipo de grelha é formado por elementos (barras) fixos alternados com elementos dotados de movimento de vaivém. Os elementos móveis empurram o lixo por cima dos elementos fixos promovendo o movimento através da câmara de combustão e a agitação necessária para queima. A figura 4.7 ilustra este tipo de grelha. 


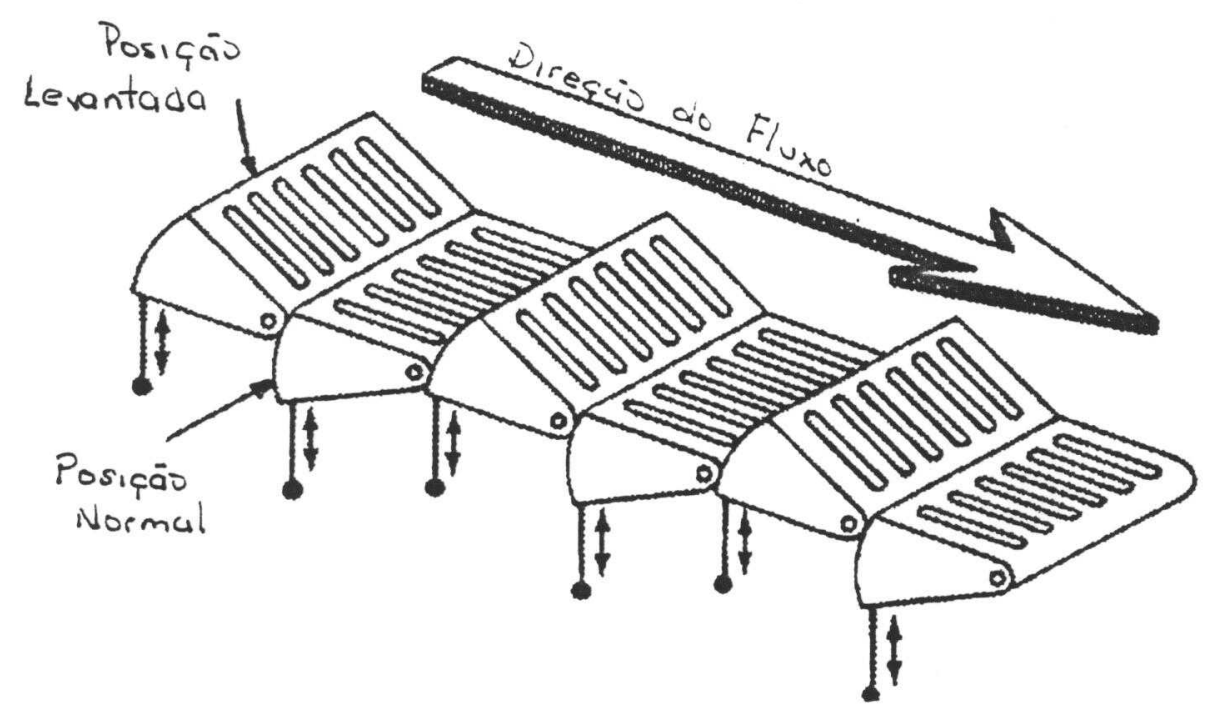

Figura 4.6 - Grelha de movimento saltante [fonte: Brunner, 1991]

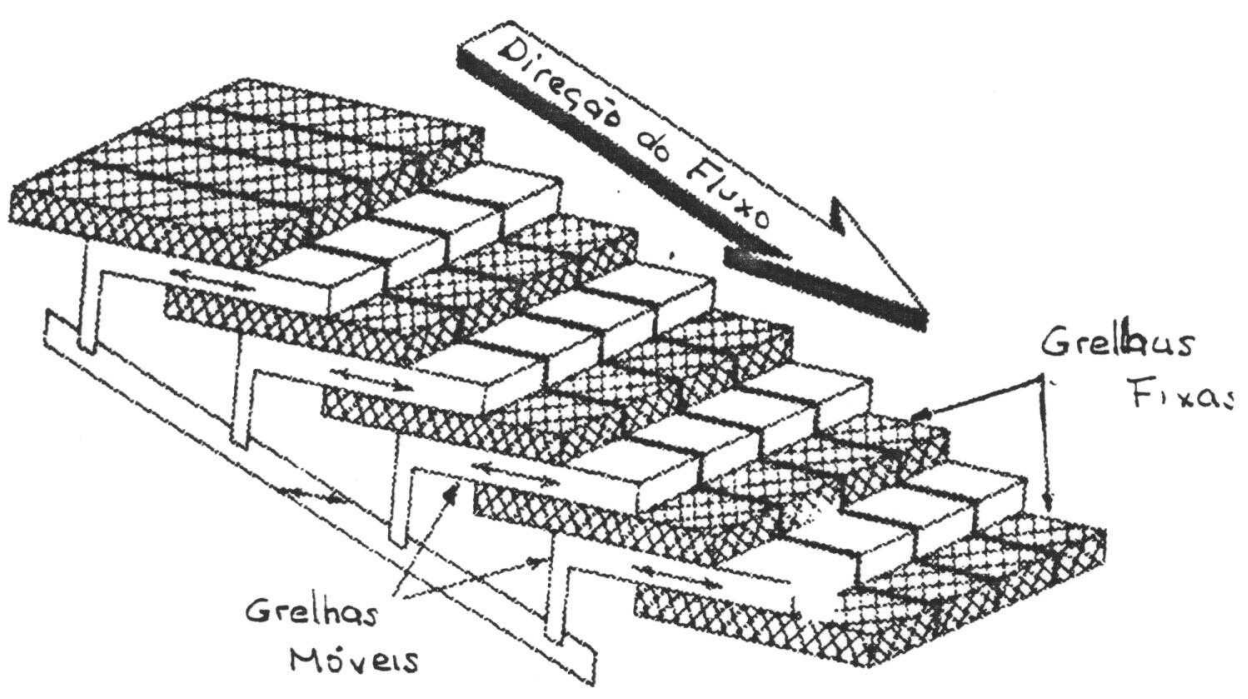

Figura 4.7 - Esquema típico de grelha de movimento alternativo linear [fonte: Brunner, 1991]

\section{Fornos Rotatórios}

Esta configuração é principalmente utilizada em incineradores de resíduos industriais perigosos. A figura 4.8 ilustra um esquema típico empregado em usinas de fornos rotatórios. Este tipo de forno é composto de um grande cilindro revestido internamente por material refratário. O projeto possui inspiração em fornos calcinadores empregados na indústria de cimento. Existem diversas variantes desta tecnologia de acordo com a aplicação (tipo de residuo. composição) e o modo de operação desejado. 
De uma forma geral, esta tecnologia é flexível quanto ao tipo de resíduo a ser incinerado. Deve-se ressaltar. entretanto, que esta flexibilidade é expressa pelas pequenas modificações estruturais entre fornos destinados a incineração de um ou outro tipo de resíduos, não implicando que um mesmo forno possa aceitar qualquer tipo de resíduo. É possivel projetar um forno desta tecnologia para queima de múltiplos resíduos. Combinações usuais são incineração de lama de esgoto em conjunto com resíduos sólidos urbanos ou a alimentação de resíduos acondicionados dentro de tambores. Também é possível a incineração conjunta com resíduos gasosos.

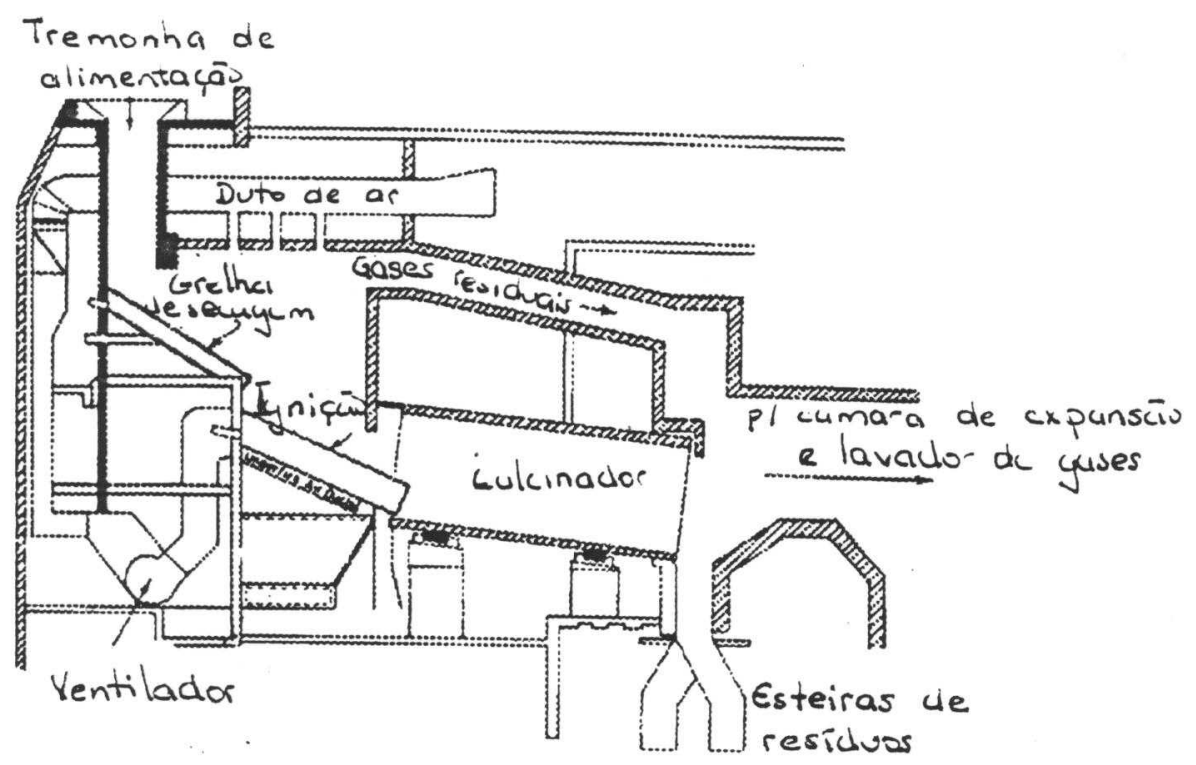

Figura 4.8 - Esquema de um forno rotatório [fonte: Brunner, 1991]

\section{Sistema Martin ${ }^{\circledR}$ ou GEC Alsthon}

Este é um sistema proprietário alemão comercializado nos Estados Unidos pela Ogden Co. Existe, no Brasil, uma representação do detentor desta tecnologia.Mostrado na figura 4.9, este sistema é uma variação do sistema de barras de atiçamento linear, diferindo pelo movimento inverso das barras. As barras que suportam as grelhas são ocas permitindo o fluxo de ar primário e promovendo a refrigeração das barras. $\mathrm{O}$ atiçamento, como mencionado, é realizado no sentido inverso conduzindo a brasa até o topo da grelha promovendo assim a secagem rápida e ignição do lixo recém-introduzido na formalha. 


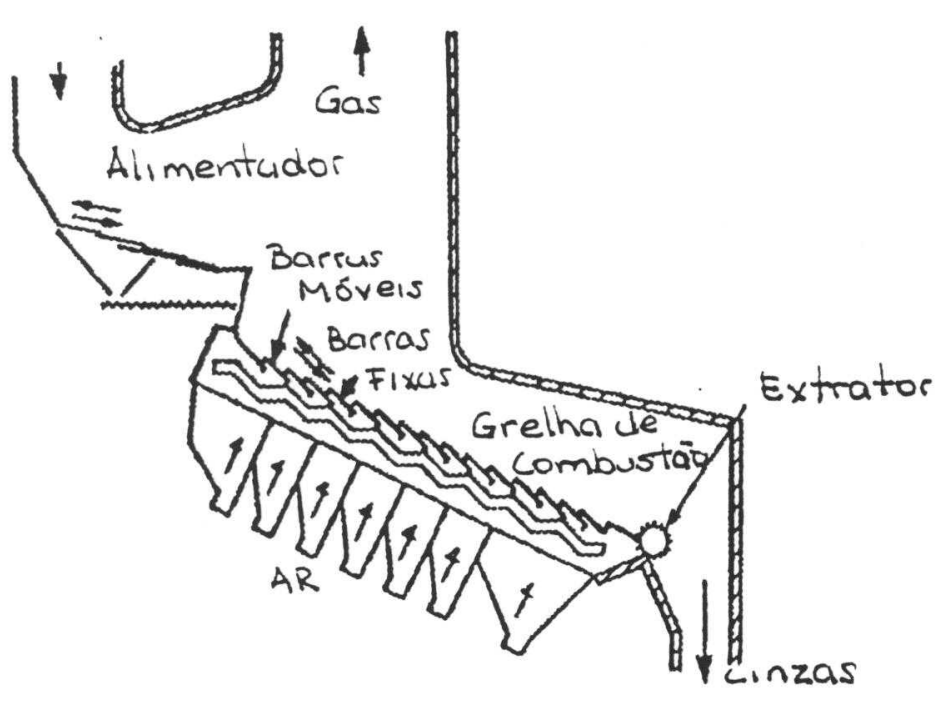

Figura 4.9 - Fornalha e grelha do Sistema Martin

\section{Sistema Von Roll ${ }^{\circledR}$}

Este é outro sistema europeu bastante empregado em grandes usinas de incineração. No Brasil, a Von Roll é representada pela A. Araújo Engenharia. Nos Estados Unidos é comercializado pela empresa Wheelabrator. Este sistema divide as grelhas em três seções conforme as zonas de combustão descritas anteriormente neste capítulo. A figura 4.10 ilustra esta configuração. Nestas seções o esquema seguido é similar ao ilustrado na figura 4.7.

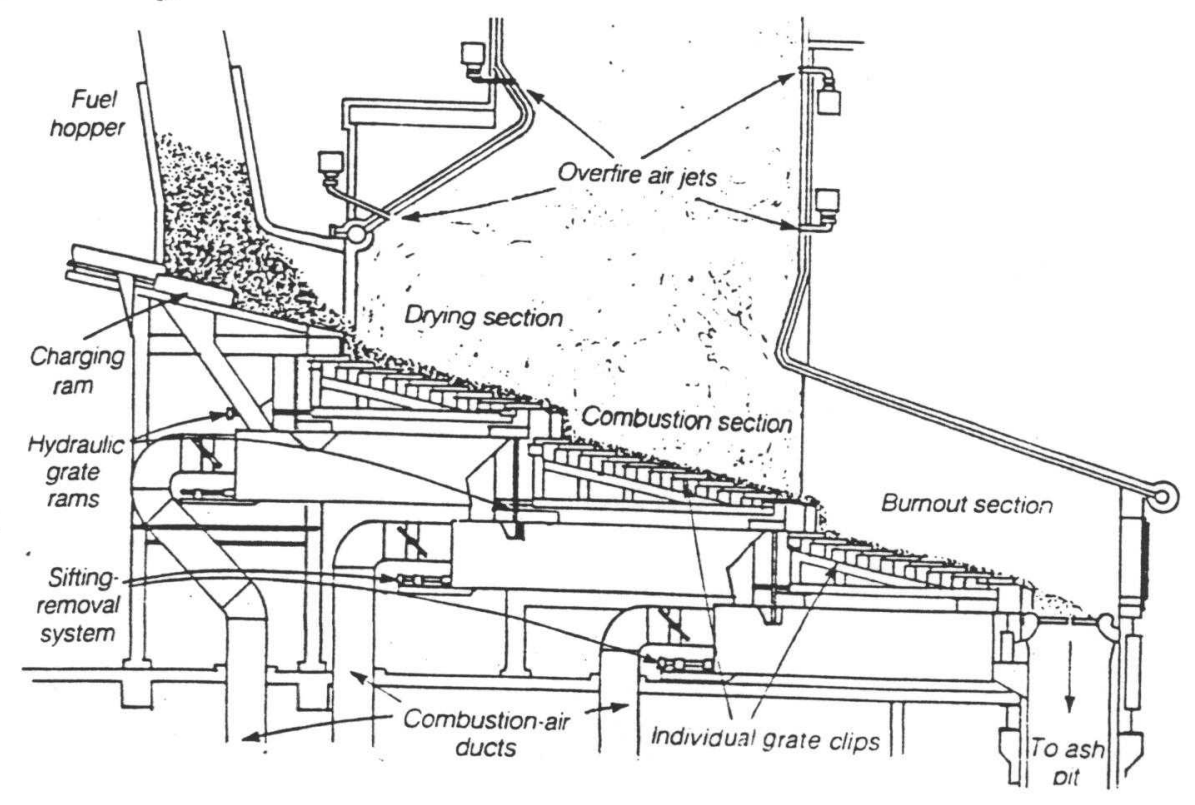


Figura 4.10 - Sistema Von Roll

\section{Sistema VKW ${ }^{\circledR}$}

Este sistema, mostrado esquematicamente na figura 4.11 e em uma foto na figura 4.12, foi desenvolvido no início da década de 60 pela empresa Vereinigte Kesselwerke sediada na Alemanha e é também conhecido como Grelha DBA (Deutsche Babcock Anlagen AG) ou Grelha Rolante Düsseldorf. Neste sistema, um conjunto de 6 tambores substitui as barras. A parcela de ar fornecida por baixo do leito passa através de aberturas existentes nestes tambores. É possível controlar tanto a velocidade de cada tambor como também a quantidade de ar fornecida através dele. A série de tambores é colocada na base da fornalha em um ângulo de $30^{\circ}$. A grelha está dividida em três zonas operacionais. A primeira, zona de secagem, corresponde aos tambores 1 e 2; a pirólise e gaseificação ocorrem do $2^{\circ}$ ao $5^{0}$ tambor; e a zona de destruição total, ou queima final, corresponde aos tambores 5 e 6 . .

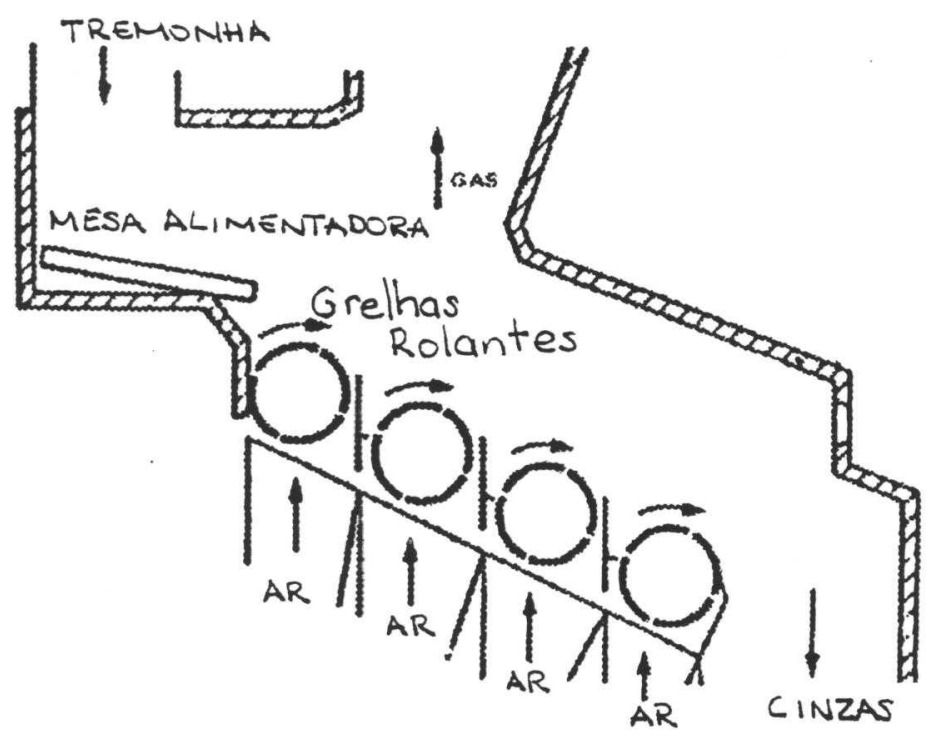

Figura 4.11- Sistema VKW (Grelha DBA)

\section{Sistema Alberti Fonsar ${ }^{\circledR}$}

Este sistema foi desenvolvido pela empresa italiana de mesmo nome. O sistema, 
conforme mostrado na figura 4.13, é composto de uma grelha com uma só seção com os elementos arranjados em degraus. A alimentação é realizada por um pistão localizado logo abaixo do funil de carga que empurra os resíduos sobre a grelha. Os degraus são fixos e uma serie de barras que intercalam os degraus agitam o lixo conduzindo-o ao degrau seguinte.

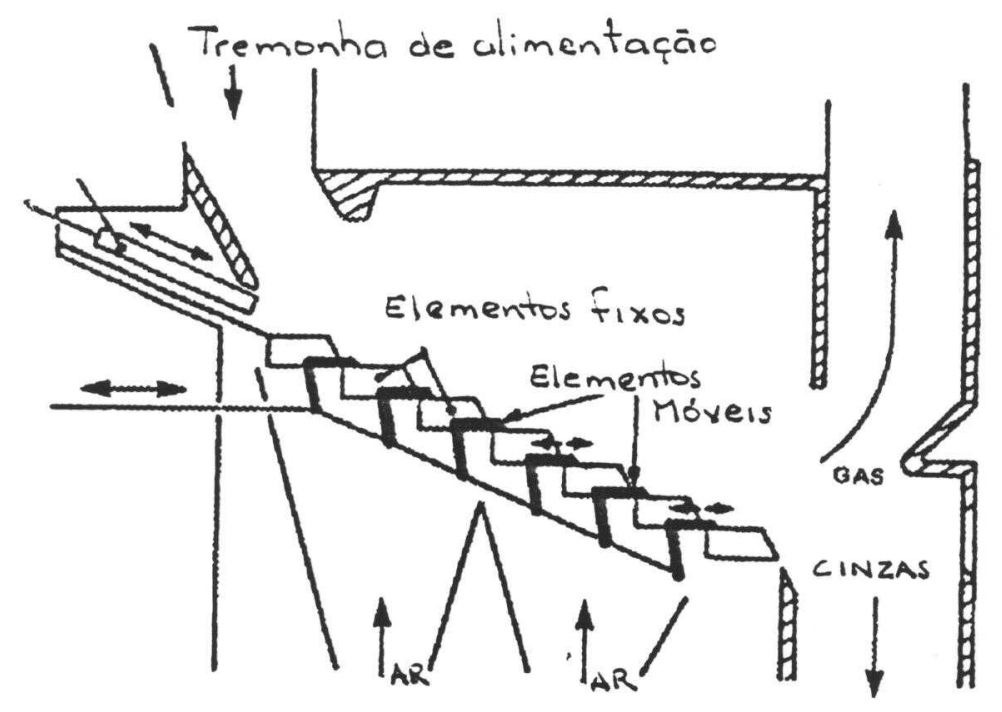

Figura 4.13 Sistema Alberti

\section{Sistema Esslingen ${ }^{\circledR}$}

A figura 4.14 ilustra o sistema Esslingen desenvolvido pela empresa alemã de mesmo nome. Este sistema combina duas formas de grelha. Uma primeira grelha é composta de uma esteira simples que alimenta uma grelha de elementos saltantes (rocking). Os elementos possuem formato de prisma com extremidades arredondadas. $\mathrm{O}$ ar é fornecido em diversas seções sob a grelha, refrigerando-a e provendo oxigênio para a combustão do lixo.

\section{Sistema Heenan Nichol ${ }^{\circledR}$}

Este sistema de firma inglesa também possui três seções distintas arranjadas na forma de degraus. Elementos alternados possuem movimento saltante simultâneo. Assim, a cada momento metade dos elementos estão se movimentando e a outra metade parada.(ver fig 4.15) 
Figura 4.12 - Grelha rolante DBA 


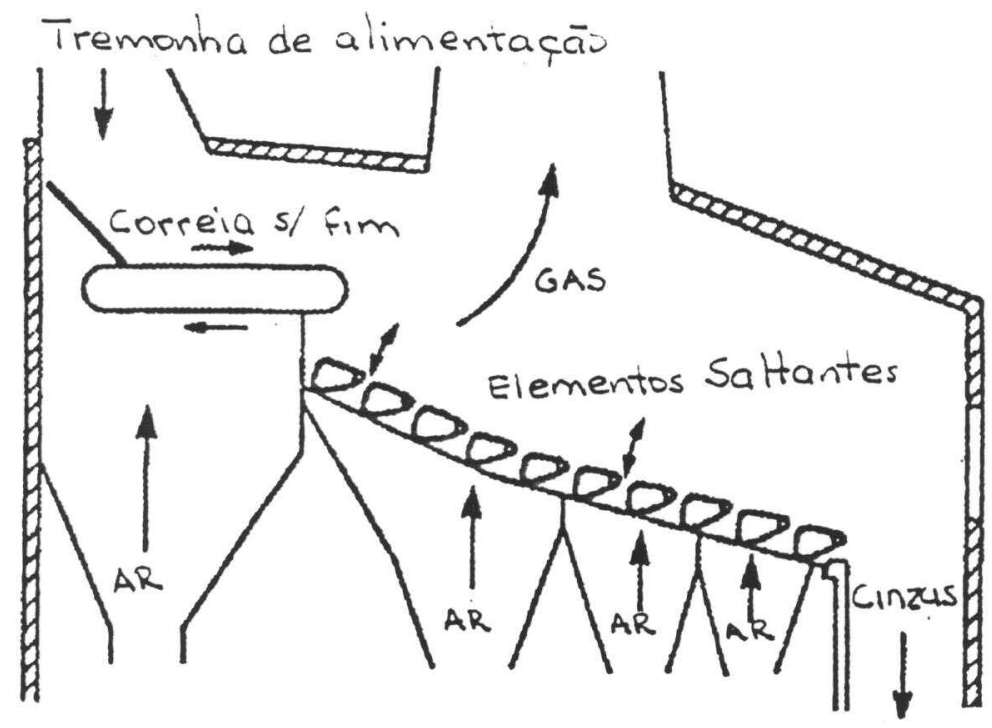

Figura 4.14 Sistema Esslingen

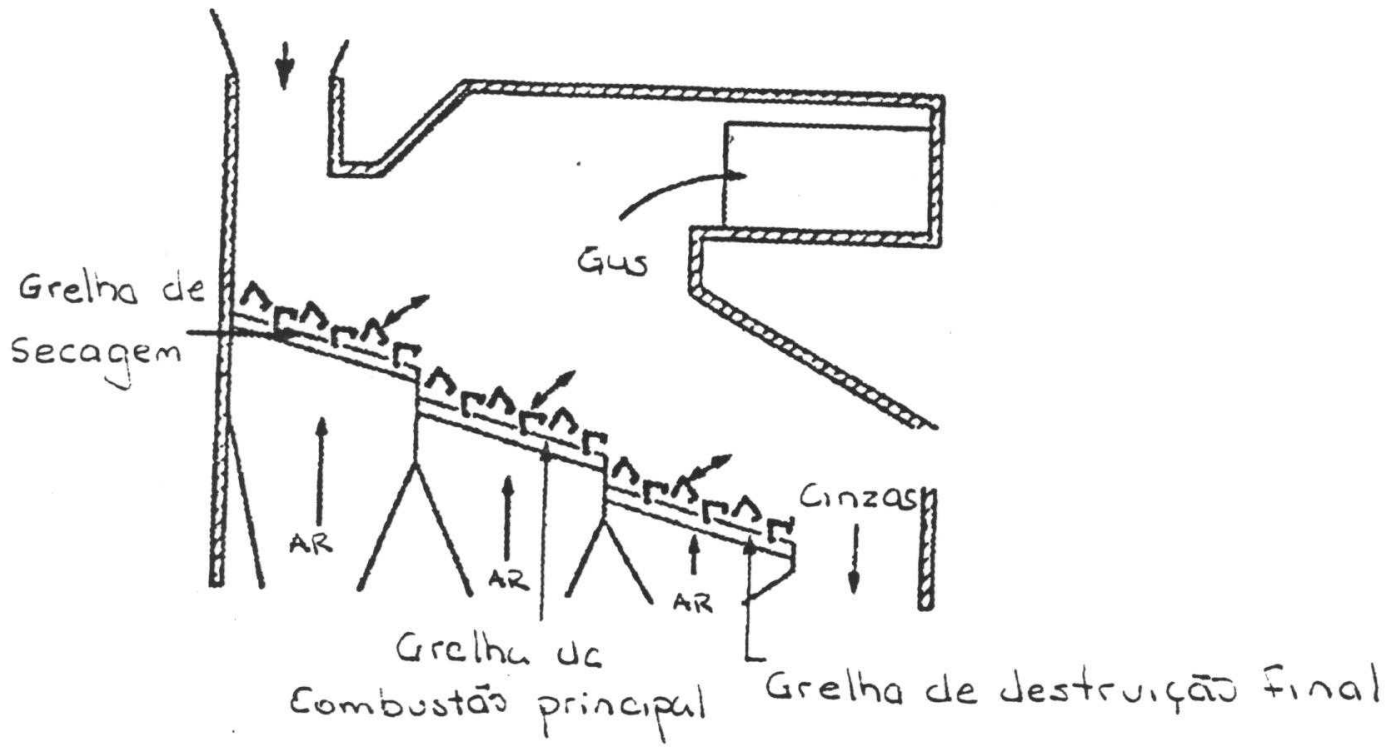

Figura 4.15 - Sistema Herman Nichol

\section{Sistema Bruun and Sorensen ${ }^{\circledR}$}

Este sistema é formado por uma sequência de cilindros disposta em um plano inclinado. A grelha é divida em seções como em outras configurações, cada seção possuindo até seis cilindros. Os cilindros ímpares têm movimento horário e os cilindros pares, movimento anti-horário. $\mathrm{O}$ ar passa entre os cilindros e através destes graças a 
fendas projetadas para a refrigeração dos mesmos. O movimento contra-rotativo promove a agitação do leito enquanto a inclinação da rampa favorece o transporte através da grelha.

\section{Sistema CEC - Carbonisation Enterprise et Céramique ${ }^{\circledR}$}

O sistema CEC, francês, é mostrado esquematicamente na figura 4.16. Este sistema é uma combinação dos outros esquemas de barras. A grelha é formada por uma única seção. Os elementos são arranjados da seguinte forma: deslizante, saltante e fixo. Os elementos deslizantes e saltantes são sincronizados de forma que, quando o elemento saltante está inerte, o elemento deslizante corre sobre ele. Assim o lixo é conduzido pelos elementos deslizantes, enquanto a agitação do leito é promovida pelos elementos saltantes.

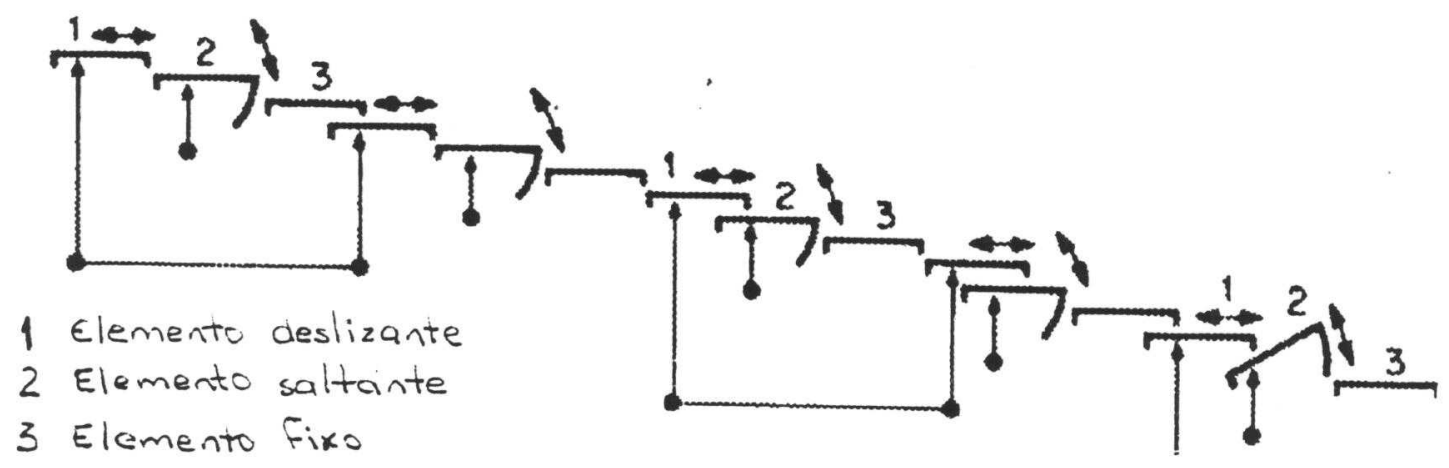

Figura 4.16 - Sistema CEC

\section{Sistema Volund ${ }^{\circledR}$}

Este sistema é comercializado nos Estados Unidos pela Waste Management Inc. e no Brasil pelas Industrias Villares. Este sistema é formado por três seções, sendo as duas primeiras de barras móveis e a terceira é um forno rotativo. As duas primeiras seções são destinadas à secagem e combustão inicial dos resíduos e a terceira à queima final proporcionando um tempo de residência maior para os resíduos de dificil queima.(figura 4.17) 


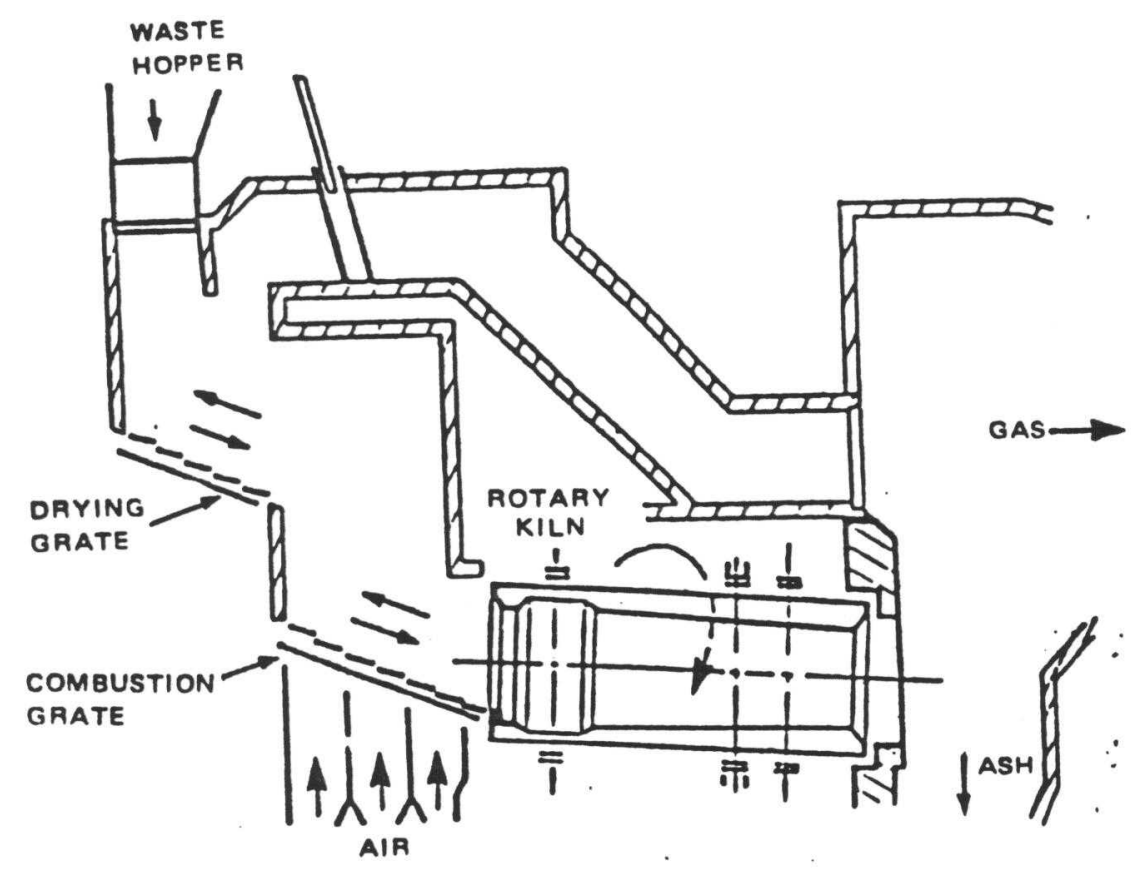

Figura 4.17 - Sistema Volund

\section{Sistema W+E/ABB}

A grelha desenvolvida por este consórcio germano-suiço é mostrada na figura 4.18. Esta grelha está disposta na horizontal e não possui degraus internos. $\mathrm{O}$ atiçamento é inverso promovido por filas de elementos móveis que são intercaladas por filas de elementos fixos. Este movimento agita e mantém o resíduo girando lentamente. Segundo o fabricante, a disposição horizontal da grelha garante um avanço controlado do resíduo, evita que o lixo acondicionado em sacos rolem através do incinerador e diminui a emissão de particulados. As zonas de queima são controladas pelo fluxo de ar primário distribuido por difusores independentes e pelo movimento dos elementos. O controle desta grelha permite que ocorra a queima completa de pneus. 


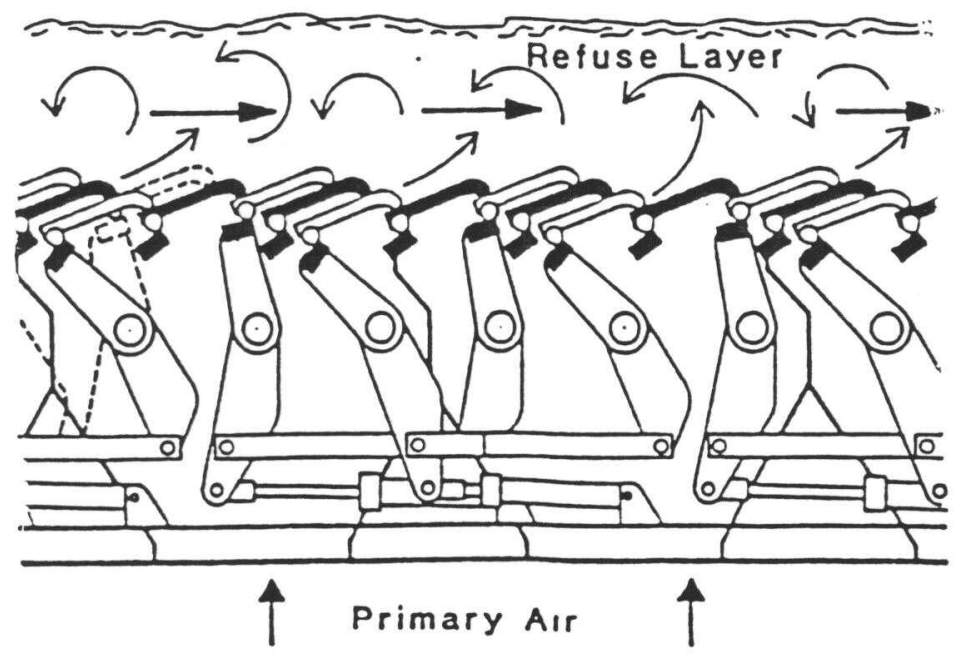

Figura 4.18 - Grelha ABB

\section{Sistema Westinghouse O'Connor}

O sistema Westinghouse O'Connor é uma derivação dos sistemas de Calcinadores Rotatórios. Aqui a parede do cilindro é construida alternando tubos de agua e membranas perfuradas de aço soldadas entre si para formar o forno conforme mostrado na figura 4.19 abaixo. O cilindro rotaciona numa velocidade de aproximadamente 6 revoluções por hora. As perfurações nas membranas entre os tubos de agua proporcionam uma distribuição adequada de ar e a agua nos tubos retira o calor gerado. 


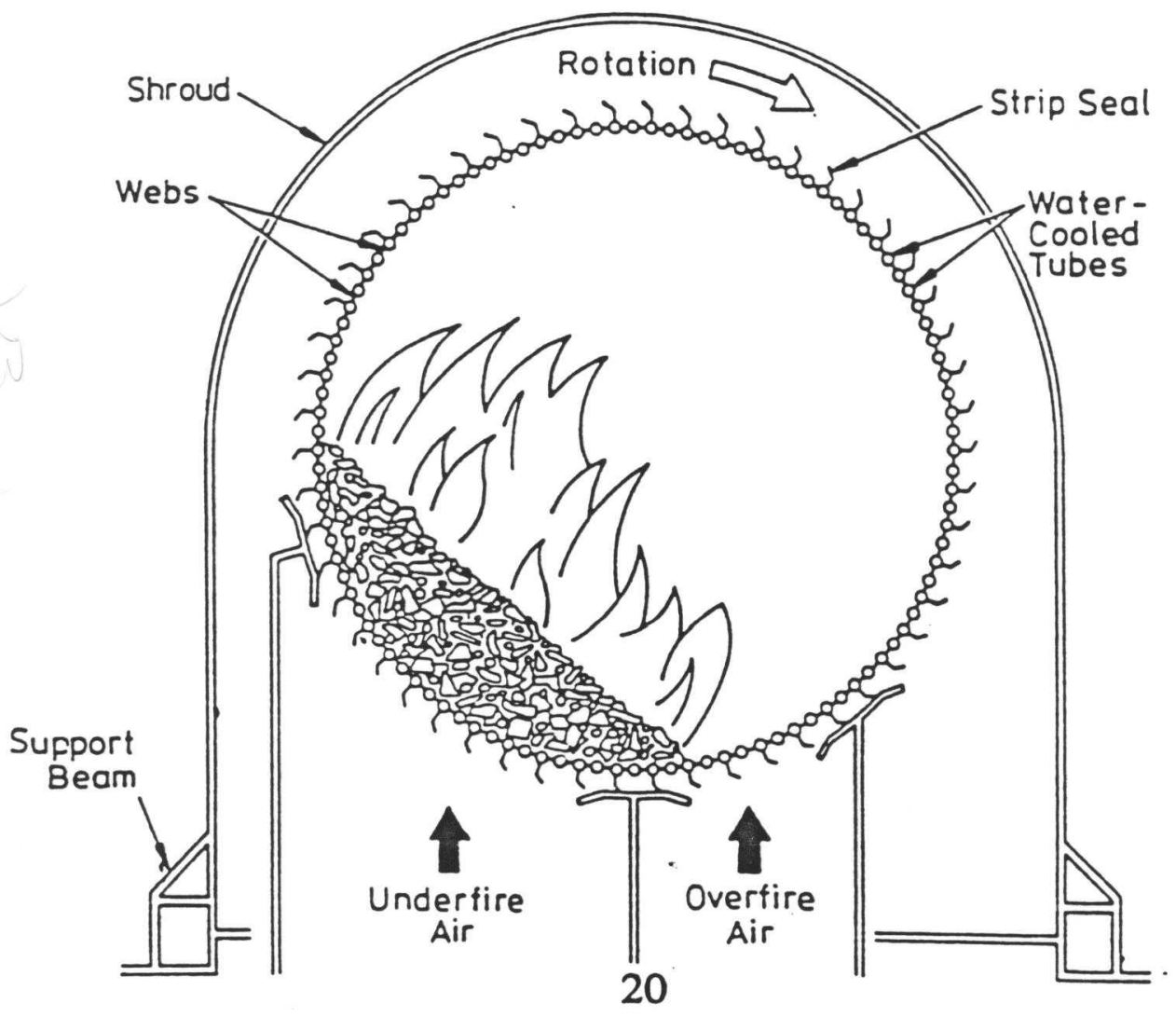

Figura 4.19 - Sistema Westinghouse O'Connor

A tabela 4.2 mostra os principais fabricantes de usinas de incineração no mundo. Algumas destas empresas atuam somente como fabricantes e outras como empresas de escopo completo podendo fornecer desde o planejamento da usina a operação. Muitas empresas trabalham no esquema "turn-key" (concepção, projeto, construção, supervisão, comissionamento). 
Tabela 4.2 - Principais empresas fabricantes de usinas de incineração de RSU no mundo

\begin{tabular}{|l|l|l|}
\hline \multicolumn{1}{|c|}{ Empresa } & \multicolumn{1}{c|}{ Pais } & \multicolumn{1}{c|}{ Tecnologias } \\
\hline ABB / W+E & Suica / Alemanha & GHALI \\
\hline AHLSTROM & Finlandia & GEVT, RK, \\
\hline American REF-FUEL & EUA & GIDBA \\
\hline BABCOCK \& WILCOX & EUA & GI, LFC, RK, PYR, GDBA \\
\hline BS Miljoteknik A/S & Dinamarca & GIS \\
\hline EBARA & Japao & LFC \\
\hline FOSTER WHEELER & EUA / RU & GIAL, LFC \\
\hline GOTAVERK & Suecia & GHAL, LFC, LFB \\
\hline MARTIN & Alemanha & GIAI \\
\hline ML MAB & Alemanha & GDBA, GIAL, LFB, PY \\
\hline OUTOKUMPU & Finlandia & LFC \\
\hline STEIN / ALSTHON & Franca & GIAL \\
\hline STEINMULLER & Alemanha & GIAL \\
\hline THYSSEN & Alemanha & LFC \\
\hline VOLUND & Dinamarca & GIS\&AL \\
\hline VON ROLL & Suica & GIAL, RK \\
\hline WESTINGHOUSE & EUA & G Westinghouse \\
\hline WHEELABRATOR & EUA & \\
\hline
\end{tabular}

Tecnologias

GI- Grelha Inclinada

GH-Grelha Horizontal

$$
\begin{aligned}
& \text {-AL Atiçamento Linear } \\
& \text {-AI Atiçamento Inverso } \\
& \text {-S Sahante "rocking" } \\
& \text {-DBA }
\end{aligned}
$$

RK- Forno Rotatório "Rotary Kiln"

LFC-Leito Fluidizado Circulante

LFB-Leito Fluidizado Borbulhante

PY-Pirolise

\subsection{Sistemas de recuperação de calor}

A combustão dos resíduos sólidos gera uma quantidade razoável de energia térmica e os gases de exaustão encontram-se então a temperaturas elevadas na saída da câmara de combustão. Os sistemas de controle de emissões possuem uma temperatura máxima para operação fazendo com que seja necessário a diminuição da temperatura dos gases antes do seu tratamento. Esta retirada de energia térmica pode ser realizada através da passagem dos gases por uma torre de resfriamento ou por uma caldeira de recuperação. Na primeira opção a energia é transferida a outro fluido, geralmente água, e perdida. Na segunda opção, é gerado vapor que pode ser utilizado em outros processos 
que necessitem de calor ou para geração de eletricidade pela expansão em uma turbina a vapor.

O quadro 4.3 abaixo mostra uma comparação entre os sistemas com ou sem recuperação de calor:

Tabela 4.3 - Comparação entre usinas com e sem recuperação de calor

\begin{tabular}{ll}
\hline Com Recuperação de Calor & Sem Recuperação de Calor \\
\hline $\begin{array}{l}\text { Temperaturas e volumes menores dos gases } \\
\text { devido a absorção de calor pelo sistema de } \\
\text { recuperação }\end{array}$ & Temperaturas mais altas dos gases \\
$\begin{array}{l}\text { Excesso de ar moderado } \\
\text { Tamanho razoável da fornalha }\end{array}$ & $\begin{array}{l}\text { Alta quantidade de excesso de ar necessario para } \\
\text { controlar a temperatura na fornalha }\end{array}$ \\
$\begin{array}{l}\text { Ventiladores e dutos menores devido às menores } \\
\text { necessidades de ar e volumes menores na } \\
\text { exaustão }\end{array}$ & Grande fornalha revestida com material refratario \\
$\begin{array}{l}\text { Investimento em equipamentos adicionais } \\
\text { (fornalha com paredes de agua, cilindros de } \\
\text { vapor, equipamentos auxiliares) }\end{array}$ & Não necessita equipamentos de vapor \\
$\begin{array}{l}\text { Operação mais trabalhosa envolvendo çontrole do' } \\
\text { vapor, monitoramento da queima, etc }\end{array}$ & $\begin{array}{l}\text { Operação relativamente simples } \\
\begin{array}{l}\text { Possibilidade de corrosão nos tubos de vapor e } \\
\text { nos sistemas de tratamento dos gases }\end{array}\end{array}$ \\
$\begin{array}{l}\text { Operadores qualificados para operação de } \\
\text { caldeiras }\end{array}$ & $\begin{array}{l}\text { Problemas de corrosão restritos ao sistema de } \\
\text { tratamento dos gases }\end{array}$ \\
$\begin{array}{l}\text { Possibilidade de receitas pela venda do vapor } \\
\text { e/ou eletricidade }\end{array}$ & $\begin{array}{l}\text { caldeiras a vapor } \\
\text { Sem receitas possiveis }\end{array}$ \\
\hline
\end{tabular}

Fonte: BRUNER, 1991 (op.cit)

A decisão de instalação de recuperadores de calor é baseada em uma análise de viabilidade do investimento adicional e do retorno esperado com a venda de energia. De um modo geral, e considerando preços razoáveis de energia, esta viabilidade passa a existir a partir de sistemas de médio porte. Conforme mostramos na tabela 3.1 , a maior parte das grandes usinas de incineração de RSU possui alguma forma de recuperação de calor.

Existem diversas configurações possiveis para caldeiras de recuperação conforme mostrado na figura 4.20. No caso de incineradores o usual é o emprego de fornalhas com 
mentalidade "de linha de produção". Cada caldeira deve possuir projeto próprio atendendo as restrições que lhe são particulares. Outra precaução é evitar encarar a caldeira somente como um gerador de vapor. Hoje a tendência é encara-la como um reator químico que auxilia na entrega, dentro das restrições econômicas, do gás de exaustão mais limpo possível ao sistema de tratamento dos gases efluentes. [MAKANSI, 1992].

Uma característica em particular distingüe o projeto de caldeiras de recuperação de incineradores de RSU para as convencionais: o seu projeto é baseado na quantidade de resíduo disponível e no poder calorífico deste, ao contrário das convencionais onde a partir de uma necessidade de energia e da eficiência da caldeira se determina a quantidade de combustivel a ser queimadas.

Outros aspectos importantes a considerar são a variabilidade do poder calorífico do RSU e o alto teor de cloretos e elementos metálicos presentes no RSU. O projeto então deve permitir um controle melhor do vapor gerado e incluir ligas e refratários resistentes à corrosão e à fadiga térmica. Estes fatores também limitam a pressão e temperatura no superaquecedor. Atualmente o limite superior para a pressão do superaquecedor é $450 \mathrm{C}$ e $65 \mathrm{kgf} / \mathrm{cm}^{2}$ [s.a., 1992]. Estes valores permitem obter $16 \%$ mais energia por tonelada incinerada do que os valores típicos de $400 \mathrm{C}$ e $43 \mathrm{kgf} / \mathrm{cm}^{2}$. [GIBBS, 1988]. Estudos de novas ligas e coberturas tem sido realizados em uma tentativa de aumentar este valor. Fuica [FUICA, 1990] propõe a instalação de um superaquecedor externo, queimando combustíveis convencionais, de forma a aumentar a qualidade do vapor para aproximadamente $540 \mathrm{C}$ e $105 \mathrm{kgf} / \mathrm{cm}^{2}$. Segundo este autor, estas medidas permitiriam aumentar a saída de uma usina de 30MW para 64MW, obtendo-se assim mais receitas com a venda de energia. 
tubos de água nas paredes na seção radiante e trocadores convectivos no superaquecedor, economizador e pre-aquecedor de ar.

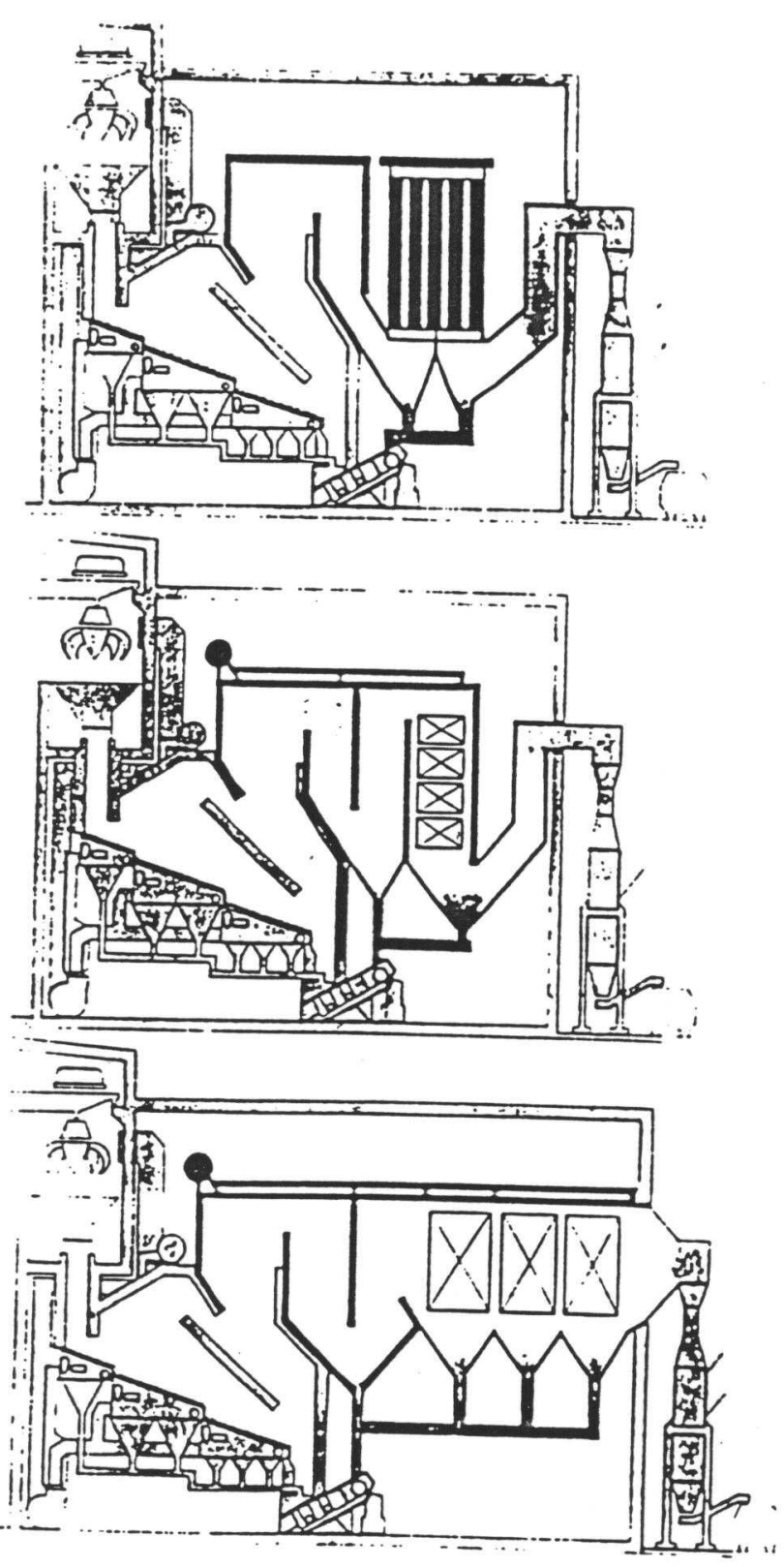

Figura 4.20 - Três configurações de caldeiras de recuperação

O projeto de caldeiras de recuperação sempre foi uma tarefa dificil de engenharia. O processo de otimização envolve um grande número de variáveis: custo de capital, custo de O\&M, espaço disponível, vida útil, restrições ambientais, flexibilidade operacional, confiabilidade, etc. Uma das preocupações no projeto é se evitar a 
mentalidade "de linha de produção". Cada caldeira deve possuir projeto próprio atendendo as restrições que the são particulares. Outra precaução é evitar encarar a caldeira somente como um gerador de vapor. Hoje a tendência é encara-la como um reator químico que auxilia na entrega, dentro das restrições econômicas, do gás de exaustão mais limpo possível ao sistema de tratamento dos gases efluentes. [MAKANSI, 1992].

Uma característica em particular distingüe o projeto de caldeiras de recuperação de incineradores de RSU para as convencionais: o seu projeto é baseado na quantidade de resíduo disponível e no poder calorifico deste, ao contrário das convencionais onde a partir de uma necessidade de energia e da eficiência da caldeira se determina a quantidade de combustível a ser queimadas.

Outros aspectos importantes a considerar são a variabilidade do poder calorífico do RSU e o alto teor de cloretos e elementos metálicos presentes no RSU. O projeto então deve permitir um controle melhor do vapor gerado e inchuir ligas e refratários resistentes à corrosão e à fadiga térmica. Estes fatores também limitam a pressão e temperatura no superaquecedor. Atualmente o limite superior para a pressão do superaquecedor é $450 \mathrm{C}$ e $65 \mathrm{kgf} / \mathrm{cm}^{2}$ [s.a., 1992]. Estes valores permitem obter $16 \%$ mais energia por tonelada incinerada do que os valores típicos de $400 \mathrm{C}$ e $43 \mathrm{kgf} / \mathrm{cm}^{2}$. [GIBBS, 1988]. Estudos de novas ligas e coberturas tem sido realizados em uma tentativa de aumentar este valor. Fuica [FUICA, 1990] propõe a instalação de um superaquecedor externo, queimando combustiveis convencionais, de forma a aumentar a qualidade do vapor para aproximadamente $540 \mathrm{C}$ e $105 \mathrm{kgf} / \mathrm{cm}^{2}$. Segundo este autor, estas medidas permitiriam aumentar a saida de uma usina de 30MW para 64MW, obtendo-se assim mais receitas com a venda de energia. 


\section{Capítulo 5}

\section{Emissões Atmosféricas em Incineradores de RSU}

O controle e tratamento de efluentes nos sistemas de incineração são aspectos importantes a serem considerados em projetos de novas usinas. Pressões da população local e de grupos ambientalistas levam estes aspectos a serem avaliados e tratado com rigor crescente nos últimos anos. Também as legislações de controle ambiental estão cada vez mais rígidas tanto no Brasil como no resto do mundo. Esta é uma tendência que deverá se manter por tempo indeterminado.

Estas pressões e preocupações afetam o projeto de usinas termoelétricas convencionais mas principalmente as de incineração, dado que as emissões destas têm maior potencial de dano. O impacto destas pressões é, principalmente, sobre os custos da usina já que complexos, e caros, sistemas de tratamento dos efluentes são exigidos. Usualmente tem-se projetado sistemas muito mais restritivos do que as legislações exigem, evitando-se assim que a usina venha a ser fechada antes do fim de sua vida útil ou necessite paralizações para incorporar novos sistemas de tratamento de efluentes com vistas a atender normas mais restritivas que venham a ser impostas.

Os efluentes de usinas de incineração podem ser classificados inicialmente em três categorias:

\section{Escória}

Água de processo

Emissões de chaminé

As emissões de chaminé podem ainda ser sub-divididas em:

Particulados

Gases Ácidos 
Gases Orgânicos

Metais Pesados

Gases inertes

Nos itens subsequentes detalham-se as emissões que geram maiores preocupações como as emissões de dioxinas, furanos e metais pesados. É certo que um estudo de impacto não deve ser restrito somente a emissões de dioxinas, furanos e metais pesados. As emissões de SOx, NOx, $\mathrm{HCl}$, material particulado e odores devem ser cuidadosamente analisadas em um estudo completo das emissões atmosféricas. No presente trabalho, conforme já mencionado, procurou-se não se estender nestes temas que já são de maior conhecimento já que fazem parte das emissões de usinas termoelétricas convencionais (a carvão ou a óleo), de caldeiras e fornos diversos.

As emissões de dioxinas e furanos são os poluentes cujo controle tem sido rigorosamente exigido nos últimos anos e foram motivo de fechamento de algumas usinas de incineração na Itália, Alemanha e Estados Unidos.

Espera-se, com este trabalho, incluir nesta dissertação subsídios para uma análise científica da questão, evitando-se esconder, em curtos parágrafos ou afirmações vagas, o perigo representado por estes poluentes, mas também não sendo alarmista com informações incompletas. Desenvolve-se então este item em duas seções tratando das dioxinas e furanos separadamente.

Não será estudada a emissão de gases inertes $\left(\mathrm{CO}_{2}, \mathrm{~N}_{2} \mathrm{O}\right)$ pois normalmente sua emissão não pode ser evitada a não ser pela diminuição da operação da usina. Existe a possibilidade de uma taxação sobre o carbono emitido na forma de $\mathrm{CO}_{2}$ devido a preocupações relacionadas com o efeito estufa. Entretanto sistemas de redução (captura) de emissões de $\mathrm{CO}_{2}$ ainda estão sendo desenvolvidos e não espera-se que possuam viabilidade econômica em futuro próximo.

Exceptuando-se o caso do $\mathrm{CO}_{2}$ citado acima, as tecnologias para controle de emissões dos outros efluentes já estão dominadas e podem atender com certa folga as normas mais restritivas hoje em vigor. A tabela 5.1 colocada abaixo relaciona algumas 
das normas de emissões vigentes na Europa.

Tabela 5.1. Padrões de Emissões na Europa para Incineradores

\begin{tabular}{|c|c|c|c|c|c|}
\hline Poluente $\mathrm{mg} / \mathrm{m}^{3}$ & Alemanha 1989 & EEC, 1989 & Holanda, 1989 & Franca 1986 & Suecia, 1986 \\
\hline $\mathrm{CO}$ & 50 & 100 & 50 & $0.1 \%$ & 100 \\
\hline Poeira & 10 & 30 & 5 & 50 & 20 \\
\hline $\mathrm{SO}_{2}$ & 50 & 300 & 40 & - & $\cdot$ \\
\hline $\mathrm{NO}_{2}$ & 100 & - & 70 & - & - \\
\hline $\mathrm{HCl}$ & 10 & 50 & 10 & 100 & 100 \\
\hline HF & 1 & 2 & 1 & - & - \\
\hline $\mathrm{C} / \mathrm{C}_{\mathrm{x}} \mathrm{H}_{\mathrm{x}}$ & 10 & 20 & 10 & $10 \mathrm{ppm}$ & \\
\hline \multicolumn{6}{|c|}{ Compostos Inorganicos } \\
\hline Classe $1(\mathrm{Cd}, \mathrm{Hg})$ & $\begin{array}{c}0.1(\mathrm{Cd}), 0.1 \\
(\mathrm{Hg})\end{array}$ & 0.2 & 0.05 & 0.3 & $0.08(\mathrm{Hg})$ \\
\hline $\begin{array}{l}\text { Classe2 (As, Co, } \\
\text { Se, etc) }\end{array}$ & $\begin{array}{c}1.0 \text { (Sb, As, Pb, } \\
\mathrm{Co}, \mathrm{Cr}, \mathrm{Cu},\end{array}$ & $1(\mathrm{Ni}, \mathrm{As})$ & 1.0 & 1.0 (As) & \\
\hline $\begin{array}{l}\text { Classe3 (Pb, } \mathrm{Cr} \text {, } \\
\mathrm{Cu}, \mathrm{Zn} \text {, etc) }\end{array}$ & $\mathrm{Mn}, \mathrm{Sn})$ & 5.0 & 1.0 & 5.0 & - \\
\hline Dioxina (Eadon) & 0.1 & - & 0.1 & - & 0.1 \\
\hline Periodo media & dia & mes & hora & - & mes \\
\hline Referido a & $11 \% \mathrm{O}_{2}$ & $\begin{array}{l}11 \% \mathrm{O}_{2} \\
9 \% \mathrm{Co}_{2}\end{array}$ & $11 \% \mathrm{O}_{2}$ & $7 \% \mathrm{CO}_{2}$ & $10 \% \mathrm{CO}_{2}$ \\
\hline
\end{tabular}

Fonte: INTERNATIONAL Directory of Solid Waste Management: the ISWA Yearbook 1993/94. Copenhagen, ISWA, 1994. pag.110.

A título de comparação, elaborou-se a tabela 5.2 onde estão apresentadas as normas brasileiras.

Tabela 5.2 - Limites de emissões determinados pela RES CONAMA 03 de $28 / 06 / 1990$

\begin{tabular}{|c|c|c|c|c|}
\hline \multirow{2}{*}{ Poluente } & \multicolumn{2}{|c|}{ Padrão Primário(em $\left.\mu \mathrm{g} / \mathrm{m}^{3}\right)$} & \multicolumn{2}{|c|}{ Padrão Secundário $\left(\mu \mathrm{g} / \mathrm{m}^{3}\right)$} \\
\hline & Média anual & Limite $^{1}$ & Média anual & Limite $^{1}$ \\
\hline Part. totais em suspensão & 80 & 240 & 60 & 150 \\
\hline Fumaça & 60 & 150 & 40 & 100 \\
\hline Part. Inaláveis & 50 & 150 & 50 & 150 \\
\hline $\mathrm{SO}_{2}$ & 80 & 365 & 40 & 100 \\
\hline $\mathrm{co}$ & $10.000^{2}$ & $40.000^{3}$ & $10.000^{2}$ & $40.000^{3}$ \\
\hline $\mathrm{NO}_{2}$ & 100 & $320^{4}$ & 100 & $190^{4}$ \\
\hline
\end{tabular}

1- Limite máximo da média em 24 h. não podendo ser excedido mais de uma vez por ano;

2- em $8 \mathrm{~h}$, não podendo ser excedido mais de uma vez por ano:

3- em 1 h. não podendo ser excedido mais de uma vez por ano:

4- em 1 h. não podendo ser excedido mais de uma vez por ano; 
Para o dimensionamento e aprovação à construção e operação de uma usina deve ser realizada uma análise do impacto ambiental. O procedimento de análise de impacto ambiental inclui: caracterização das emissões, modelos de dispersão e deposição, análise de exposição, caracterização dos riscos e análise de incertezas. A caracterização das emissões provê dados e hipóteses que são utilizados para estimar as taxas de emissão para contaminantes selecionados. Os modelos de dispersão e deposição combinam as características da usina e de emissão com dados metereológicos e outros parâmetros físicos a fim de predizer as concentrações na atmosfera a nível do chão e a deposição sobre o solo e meios aquáticos na proximidade da usina. A análise de exposição visa avaliar o tipo e magnitude de exposições potenciais das populações circunvizinhas. A exposição potencial deve contemplar os todos os meios possíveis de exposição conforme esquema mostrado na figura 5.1. A estimativa do impacto desta exposição sobre a saúde humana é avaliada na caracterização do risco. De forma a interpretar e avaliar os resultados deve ser realizada uma análise de incertezas. [LEVIN, 1991]

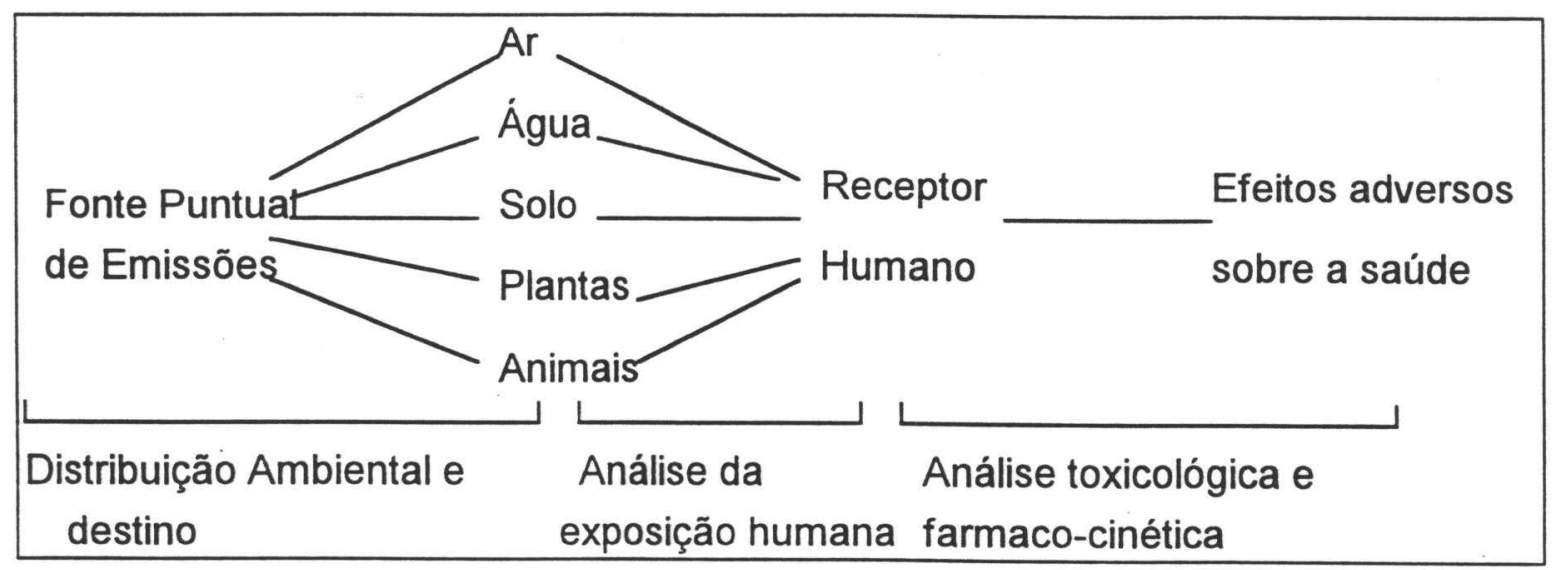

Figura 5.1: Destino ambiental e toxicológico de um produto químico. $\mathrm{Na}$ inferior estão as sub-seções de uma análise multi-meios de risco à saúde Fonte: STEVENS, 1989.

A caracterização das emissões atmosféricas deve seguir os seguintes passos: identificação dọ contaminantes relevantes, estimativa das taxas de emissão (para operação normal e condições excepcionais resultantes de problemas operacionais ou falha de equipamentos), caracterização do estado físico dos contaminantes (particulado 
ou vapor) e estimativa da distribuição de tamanho dos particulados [LEVIN, 1991].

A quantificação e qualificação destes efluentes é necessária desde a fase inicial do projeto determinando o dimensionamento, a seleção, e até mesmo o emprego de uma ou outra tecnologia de incineração visto que tanto a quantidade e quanto a qualidade dos efluentes são bastante influenciados por esta escolha. A tabela 5.3 abaixo ilustra as possíveis faixas de emissões de poluentes por incineradores de RSU.

Tabela 5.3 - Faixas de emissão de poluentes pela queima de RSU

\begin{tabular}{ll}
\hline Poluente & Faixa de taxa de emissões \\
\hline Material Particulado & $5,49-1530,0 \mathrm{gr} / \mathrm{dscf}$ a \\
Dióxido de Enxofre & $0,04-401,0 \mathrm{ppmdv}$ b \\
Óxidos de Nitrogênio & $39,0-309,0 \mathrm{ppmdv}$ \\
Monóxido de Carbono & $3,24-1350,0 \mathrm{ppmdv}$ \\
$\mathrm{HCl}$ & $7,50-1270,0 \mathrm{ppmdv}$ \\
$\mathrm{HF}$ & $0,62-15,6 \mathrm{ppmdv}$ \\
$\mathrm{As}$ & $0,45-233,0 \mu \mathrm{g} / \mathrm{Nm}^{3} \mathbf{c}$ \\
$\mathrm{Cd}$ & $6,22-942,0 \mu \mathrm{g} / \mathrm{Nm}^{3}$ \\
$\mathrm{Cr}$ & $3,57-6660,0 \mu \mathrm{g} / \mathrm{Nm}^{3}$ \\
Pb & $25,1-15500,0 \mu \mathrm{g} / \mathrm{Nm}^{3}$ \\
$\mathrm{Hg}$ & $8,69-2210,0 \mu \mathrm{g} / \mathrm{Nm}^{3}$ \\
Ni & $1,92-3590,0 \mu \mathrm{g} / \mathrm{Nm}^{3}$ \\
PCDD & $1,13-10700,0 \mathrm{ng} / \mathrm{Nm}^{3} \mathbf{~ d}$ \\
2,3,7,8 TCDD & $0,02-62,5 \mathrm{ng} / \mathrm{Nm}^{3}$ \\
PCDF & $0,42-14800,0 \mathrm{ng}^{3} \mathrm{Nm}^{3}$ \\
2,3,7,8 PCDF & $0,17-448,0 \mathrm{ng} / \mathrm{Nm}^{3}$ \\
PCB & $8,31-833,0 \mathrm{ng} / \mathrm{Nm}^{3}$ e \\
Clorobenzenos Total & $160,0-1400,0 \mathrm{ng} / \mathrm{Nm}^{3}$ \\
Clorofenóis Total & $299,0-3300,0 \mathrm{ng} / \mathrm{Nm}^{3}$ \\
\hline a Grãos por pé cúbico padrão seco & \\
b Partes por milhão em base seca por volume & \\
c microgramas por normal metro cúbico & \\
d nanogramas por normal metro cúbico & \\
e O valor inferior da faixa é uma média para instalações com dry scrubbers: o valor superior é uma média para todas instalações. \\
Fonte: STEVENS. 1989.
\end{tabular}

\subsection{Emissão de metais}

Há muito se conhece o efeito tóxico de metais pesados para o ser humano. Considera-se que a inalação de metais tem efeito mais pronunciado sobre a saúde do que a ingestão via oral ou por contato. Estudos sobre riscos potenciais sobre a saúde realizados nos EUA, mostram que o consumo de produtos contaminados oferece risco maior que a inalação, principalmente considerando os contaminantes com potencial 
carcinogênico [LEVIN, 1991]. Os metais podem ser encontrados dissolvidos ou associados aos materiais, dependendo de diversos, fatores ambientais como ph, salinidade, temperatura, etc. Vários são os fatores que podem determinar a toxidade dos poluentes metálicos em relação biosfera. Estes fatores são:

- A forma sob a qual o metal é descartado para o corpo receptor (solo, cursos d'agua e ar);

- A presença de outros metais e/ou substâncias estabelecendo-se determinados fenômenos de sinergismo ou antagonismo que têm como resultado o aumento ou a diminuição de toxidade do metal em relação biosfera;

- Variação das condições ambientais;

- Condições físicas ou fisiológicas dos organismos afetados;

- Reação do organismo presença do poluente.

Os metais que têm efeito mais grave sobre a saúde humana são:

Chumbo - Este metal tem efeito acumulativo no organismo. Não existem indicações de bioconcentração de chumbo por plantas, sendo a rota mais comum via mamíferos que ingerem o chumbo em particulados como solo, poeira ou pigmentos.[KORZUN, 1990]. Causa sintomas como anemia, dores de cabeça, esterilidade, anormalidades congênitas em recém nascidos. Estas anormalidades, conhecidas como encefalopatia do chumbo, incluem convulsões, coma, cegueira, retardamento mental, ou morte.

Níquel - A forma NiCO é a forma considerada danosa para a saúde humana. Causa mudanças na estrutura pulmonar o que leva a doenças pulmonares inclusive câncer de pulmão [BRUNNER, 1991].

Cádmio - Este elemento está associado com a incineração de produtos contendo cádmio como pneus, certos plásticos e pigmentos. Seu efeito sobre o organismo humano é a interferência no metabolismo do zinco e do cobre. Quando o cádmio está presente no solo, algumas plantas são capazes de capturá-lo seletivamente e levam a concentrações que são de quatro a dez vezes maiores do que a do solo em que 
cresceram. Estudos revelam a possibilidade de causar doenças cardiovasculares e hipertensão e é um importante agente carcinogênico .Em análise de estudos de risco à saúde realizados para usinas de incineração nos EUA mostram que o cádmio contribui com até $70 \%$ do total do risco carcinogênico em emissões de incineradores[LEVIN, 1991].

Mercúrio - O mercúrio já é reconhecido a muito como um importante poluente da água. Tem efeito acumulativo nos organismos. Por causa de seu ponto de ebulição baixo é eliminado na atmosfera quando resíduos contendo este elemento são queimados ou aquecidos. Os efeitos sobre o organismo são a cegueira, enfraquecimento muscular, paralisia, coma, ou morte. Também pode causar importantes deformações no desenvolvimento do feto [BRUNNER, 1991].

Cromo - A forma hexavalente ( $\mathrm{Cr} 6+)$ é cancerígena. A previsão da quantidade de Cr 6+ emitidas por incineradores de RSU é uma tarefa dificil visto que não existe ainda um consenso científico, com estudos apresentando resultados distintos quanto à composição percentual de Cr6+ no total de emissões de Cr. [LEVIN, 1991].

Poucos dados estão disponíveis sobre a emissão de metais pesados pelos gases de combustão em incineradores. Dos quatro metais de maior interesse, chumbo, níquel, cádmio, mercúrio, a pior situação é aquela na qual estes metais são lançados pela chaminé na forma de óxidos e nenhuma parcela fica retida nas cinzas. [BRUNNER, 1998] Além destes metais citados, também devem ser monitoradas as emissões de Arsênio (As), Cromo (Cr), Mobilidênio (Mo) e Selênio (Se). [BRNA, 1990 e KORZUN, 1990].

A repartição dos metais entre os diferentes rejeitos da incineração (gases, cinzas de filtros e escória) é determinada pela temperatura de ebulição e do comportamento com relação a outros elementos presentes no lixo. A figura 5.2 apresenta as curvas de repartição dos metais entre os produtos de combustão em função da temperatura de ebulição. O coeficiente mostrado nas ordenadas é o quociente entre a massa de um 
elemento presente no produto sobre a massa presente inicialmente no resíduo urbano.

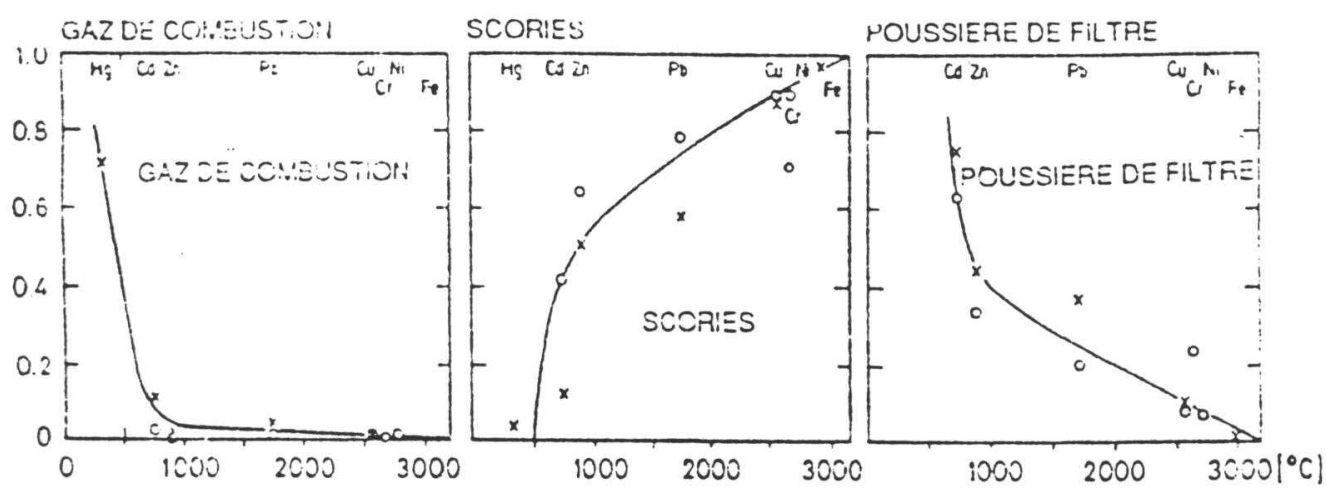

Figura 5.2 - Repartição dos metais entre os produtos de combustão em função da temperatura de ebulição.

Fonte: BRUNNER, P.H., 1988.

De uma forma mais esquemática, a figura 5.3 ilustra a repartição segundo valores médios obtidos em usina em operação na Suiça. As setas à esquerda representam a quantidade emitida juntamente com os gases de chaminé, ao centro representam a quantidade presente nas cinzas de filtro e à direita a quantidade presente na escória.

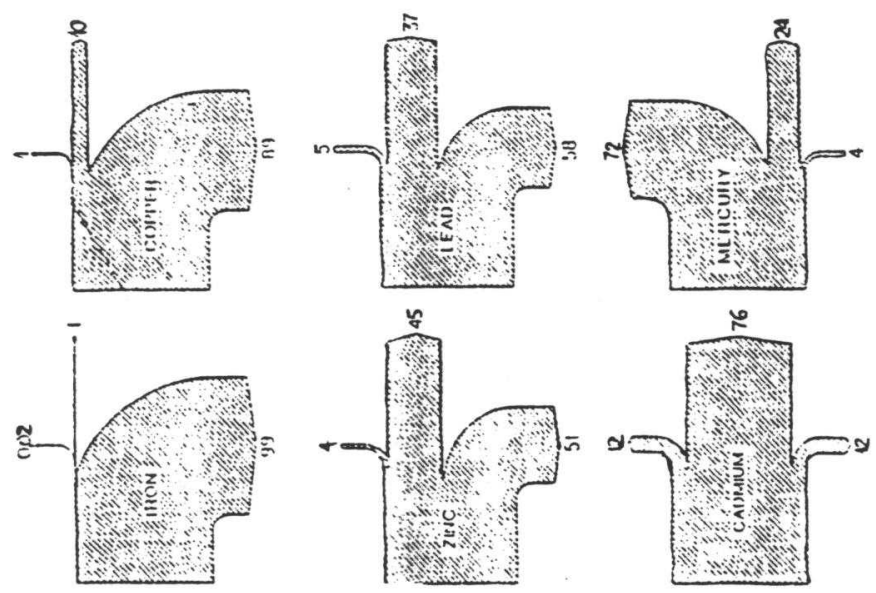

Figura 5.3 - Valores médios de repartição de metais entre os produtos de combustão. Fonte: BRUNNER, P.H., 1988.

Estudo realizado por Korzun e Heck [KORZUN, 1990], relaciona as principais 
fontes e destinação de chumbo e cádmio nos RSU. Este estudo estima que 2,3\% do chumbo e $36 \%$ do cádmio do total presente no RSU estão na parcela combustivel. É de se esperar que a parcela combustivel forme a maior parte dos particulados atmosféricos, cinzas recolhidas nos filtros e nos finos de escória. Esta parcela combustível fornece aproximadamente $75 \%$ do cádmio e $34 \%$ do chumbo presente na escória, cinzas de filtros e particulados atmosféricos. A concentração de chumbo e cádmio na parcela combustível, para os casos revisados por Korzun e Heck, é de 50 ppm e 6,6 ppm, respectivamente. A tabela 5.4 mostra os valores de concentração destas substâncias nos resíduos da incineração.

Tabela 5.4 - Concentração de Cádmio e Chumbo nos Resíduos de Incineração

\begin{tabular}{|c|c|c|c|c|}
\hline & & Escória & Cinzas de filtros & Particulados \\
\hline Cádmio & $\mathrm{mg} / \mathrm{kg}$ & $\begin{array}{c}10,74 \\
(2,22 \%)\end{array}$ & $\begin{array}{c}235 \\
(48,5 \%)\end{array}$ & $\begin{array}{c}238,8 \\
(49,28 \%)\end{array}$ \\
\hline Chumbo & $\mathrm{mg} / \mathrm{kg}$ & $\begin{array}{c}2800 \\
(20,08 \%) \\
\end{array}$ & $\begin{array}{c}5632 \\
(40,46 \%)\end{array}$ & $\begin{array}{c}5501 \\
(39,45 \%)\end{array}$ \\
\hline
\end{tabular}

As baterias chumbo-ácidas, utilizadas em automóveis e motos, e as pilhas e baterias comuns são as principais fontes de chumbo nos RSU. As baterias secas e pilhas também são uma importante fonte de cádmio, seguindo-se os plásticos. Considerando somente a parcela combustivel, os plásticos são a maior fonte de chumbo e cádmio, conforme mostrado na tabela 5.5.

Tabela 5.5 - Contribuição de materiais para o cádmio e chumbo presentes na parcela combustível do RSU.

\begin{tabular}{lcc}
\hline & Chumbo & Cádmio \\
\hline Plásticos & $71,0 \%$ & $88,0 \%$ \\
Pigmentos a & $23,8 \%$ & $10,9 \%$ \\
Borracha e óleo usado & $5,2 \%$ & $1,1 \%$ \\
\hline a Não inclui pigmentos utilizados em plásticos, vidros e borrachas. \\
Fonte: KORZUN, 1990.
\end{tabular}

Uma atuação sobre as fontes de metais pesados reduziria a quantidade emitida 
pelos incineradores. No artigo de Korzun este autor afirma que a longo prazo é mais efetivo investir na troca de pigmentos e reciclagem de metais do que investir mais nos equipamentos de controle de emissões dos incineradores e em um controle permanente e indefinido de aterros sanitários, seja das cinzas e escórias da incineração, seja dos resíduos brutos.

\subsection{Dioxinas e Furanos}

A emissão de dioxinas e furanos é talvez a maior preocupação das comunidades vizinhas e entidades ambientalistas quando se cogita a instalação de um incinerador de RSU. Estas preocupações se fundamentam nos relatos de acidentes ocorridos com emissão destas substâncias e nos inúmeros artigos técnicos alertando para o seu potencial cancerígeno.

$\mathrm{Na}$ verdade, a questão das dioxinias e furanos é usualmente obscurecida pelo temor à idéia da morte que foi associada às emissões destas substâncias, principalmente após a Guerra do Vietnam onde as dioxinas aparecem como substância tóxica associada ao desfolhante "agente laranja" espalhado pelos americanos sobre a selva vietnamita.

\subsubsection{Dioxinas}

Dioxina é o nome dado de forma genérica a um composto orgânico clorado que totaliza 75 isômeros. Sua fórmula mínima e representação gráfica são colocadas na figura 5.4 abaixo. Como pode ser observado as dioxinas se caracterizam por serem formadas por dois anéis benzênicos ligados por dois átomos de oxigênio, com oito posições livres para substituição de hidrogênio por átomos de cloro. As dioxinas tetra-cloradas têm sido extensamente estudadas e a forma isômera 2,3,7,8 tetra-cloro dibenzo-p-dioxina $(2,3,7,8$ TCDD) é considerada hoje a forma com maior potencial tóxico. Dada a importância desta forma, as emissões de dioxinas são expressas sempre na forma de toxidade equivalente a 2,3,7,8 TCDD seguindo esquemas de ponderação elaborados segundo o 
potencial tóxico de cada isômero. Existem alguns esquemas amplamente aceitos como o EADON, Califórnia No.4 ou USEPA. [LEVIN et al.. 1991]

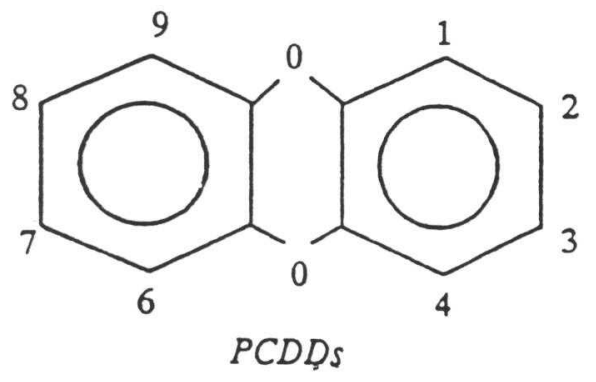

fórmula mínima $\mathrm{C}_{12} \mathrm{H}_{4} \mathrm{O}_{2} \mathrm{Cl}_{4}$

Figura 5.4 - Representação das dioxinas e fórmula mínima da TCDD.

As dioxinas não ocorrem naturalmente [DHHS/ATSDR, 1988] sendo formadas como contaminante indesejado da produção ou decomposição de compostos organoclorados (clorobenzenos, clorofenóis e derivados). A tabela 5.6 colocada abaixo relaciona concentrações de dioxinas presentes como contaminante em diversos compostos. À temperatura ambiente as dioxinas apresentam-se no estado sólido. O ponto de fusão é próximo de $305 \mathrm{C}$ e a pressão de vapor a $25 \mathrm{C}$ é de $7,4.10^{-10} \mathrm{mmHg}$ [USEPA, 1985]. Apesar desta baixa pressão de vapor as dioxinas são consideradas voláteis [FREEMAN, 1986] e estão presentes no ar atmosférico tanto na forma gasosa quanto na fase particulada. [FAILESS, 1987]. A solubilidade em água é extremamente baixa (da ordem de 19,3 ng/l e log $\mathrm{K}_{\mathrm{ow}}=7,02$ para a 2,3,7,8 TCDD) [USEPA, 1985 op cit]. Apresentam ainda características lipofilicas confirmadas em experimentos com cobaias.[SHANTZ, 1989] A decomposição térmica se inicia a $500 \mathrm{C}$ e está virtualmente completa a $800 \mathrm{C}$ após 21 segundos. [USEPA, 1985].

Tabela 5.6 - Concentração de dioxina detectada como impureza em produtos químicos Herbicida 2,4,5-T (produzido antes de 1960) até $100 \mathrm{~g} / \mathrm{g}$ Herbicida 2,4,5-T (produzido atualmente) até $0.02 \mathrm{~g} / \mathrm{g}$ Agente Laranja (antes de 1970) Hexaclorofenol até $54 \mathrm{~g} / \mathrm{g}$ 2,4,5 Triclorofenol $0-0,5 \mathrm{~g} / \mathrm{g}$ Fonte: DHHS/ATSDR, 1988 até $6.2 \mathrm{~g} / \mathrm{g}$

Atualmente dioxinas são lançadas ao meio ambiente primariamente através de 
emissões de incineradores de lixo urbano e de resíduos químicos, pela exaustão de gases de automóveis utilizando gasolina com chumbo e pela deposição imprópria de certos compostos químicos clorados. Se lançadas na atmosfera, a fase gasosa pode ser degradada pela reação com radicais hidroxil e fotólise direta. A parte particulada é retirada via deposição seca e úmida. Se lançadas a meios aquáticos as dioxinas estarão predominantemente associadas aos sedimentos e matéria em suspensão. Dioxinas próximas à superficie da água sofrem fotodegradação. Não espera-se que a dioxina depositada sobre o solo sofra lixívia. A fotodegradação é o mecanismo mais importante de destruição das dioxinas depositadas sobre o solo. A volatização é uma forma de remoção importante em condições de temperatura elevada. [DHHS/ATSDR, 1988].

Encontrou-se relatos de contaminação por dioxinas anteriores à década de $50 \mathrm{em}$ acidentes na produção de substâncias como o ASCAREL, óleo isolante para transformadores, e o 2,4,5 T, herbicida e desfolhante. Na produção destes compostos ocorre formação não desejada de dioxinas expondo trabalhadores à contaminação. Incêndios e outros acidentes em fábricas destes produtos têm conseqüências graves. Uma explosão em fábrica de produtos químicos na cidade de Seveso, Itália em 1976 é considerado um dos maiores acidentes com emissão de dioxinas. Este acidente foi bastante estudado e foram medidas grandes quantidades de dioxinas liberadas pela explosão. As autoridades levaram semanas para comunicar à população o ocorrido e os perigos resultando em séria contaminação de pessoas e animais. A 2,3,7,8 TCDD passou a ser conhecida também por dioxina de Seveso. A tabela 5.7 abaixo resume os acidentes encontrados na revisão da literatura. nos quais foi identificada a emissão e contaminação ambiental de dioxinas.

Tabela 5.7 - Acidentes com emissões de Dioxinas

\begin{tabular}{ll}
\hline Local e data & Acidente \\
\hline Milão, 1949 & falha indústria química \\
Duphar, Holanda, 1963 & Explosão fábrica 2,4,5 T \\
Inglaterra, 1968 & Explosão fábrica de 2,4,5 T \\
Seveso, Italia, 1976 & Explosão indústria química \\
Checoslováquia, 1965 & acidente fabricação 2,4,5 T \\
Love Canal, NY, EUA & acidente em aterro de produtos químicos \\
\hline ref: CD-ROM &
\end{tabular}


É importante ressaltar que não existe relato de exposição humana unicamente às TCDD. Em todas exposições conhecidas houve contaminação simultânea com outras substâncias. Além dos casos apresentados acima, existem diversos outros exemplos de contaminação associados às dioxinas. O maior dos casos de exposição a dioxinas foi a de vietnamitas e soldados americanos durante a Guerra do Vietnam. Durante esta guerra foi utilizado em larga escala o desfolhante 2,4,5 T , conhecido pelo nome de "agente laranja". Este desfolhante continha TCDD em quantidades superiores a $30 \mathrm{ppm}$ [HAY, 1979] e foi aspergido sobre a selva entre 1964 e 1968. O aumento dos casos de câncer de figado detectados nos hospitais de Hanoi durante o período de 1962 a 1968 foram associados a esta exposição - de 2,9 \% dos casos totais de câncer entre 1955/61 para $10 \%$ no período $62 / 68$ [IARC, 1977]. Três a quatro meses após ter sido interrompida a aspersão de agente laranja no Vietnam, camarões do Rio Saigon e peixes do Rio Dong Nai continham 49 a $1020 \mathrm{ng} / \mathrm{kg}$ de TCDD, índices elevados comparados a concentrações inferiores a $3 \mathrm{ng} / \mathrm{kg}$ encontrados em peixes adquiridos nos mercados de Massachusetts, EUA. [IARC, 1977].

Os efeitos relacionados à exposição crônica a TCDD ainda sofrem controvérsias científicas. Por exemplo, um relatório da agência ambiental americana, EPA, produzido em 1988 cita que 'estudos em populações humanas falharam em demonstrar claramente qualquer efeito significativo de longo prazo na saúde a níveis que estas populações foram expostas.' [CFR 401.15 7/1/88]. No entanto, estudos realizados, entre 1985 e 1986, com pacientes mulheres potencialmente expostas aos herbicidas lançados sobre o Vietnam permitiram detectar níveis 3 a 4 vezes maiores de dioxinas no tecido adiposo do que os encontrados em pessoas dos países industrializados [PHUONG, 1989] e, uma pesquisa realizada em 1979 detectou cloracne em $52 \%$ dos operários de uma fábrica que produziu 2,4,5 T até 1969 [MOSES et al., 1984].

Com relação à bioconcentração também não existe um consenso. $\mathrm{O}$ caso dos peixes dos rios vietnamitas. citado acima. é reforçado por outro estudo em que foi 
detectada bioacumulação nos tecidos adiposos de cobaias fêmeas e a transferência para o organismo em desenvolvimento durante a gestação e lactação [SHANTZ, 1989]. Outro estudo considera demonstrada a bioacumulação em organismos aquáticos [DHHS/ATSDR, 1988]. Em um artigo de Levin, é citado que 'dioxinas e furanos são substâncias com propriedades lipofilicas e tendem a se concentrar no tecido humano.' [LEVIN, 1991]. Contrapondo-se a esta afirmação, pesquisadores concluiram que não espera-se que as dioxinas tenham um potencial de acumulação em tantos sistemas biológicos como o DDT [PARR, 1983] e outros estudos realizados com ratos concluiram pela negação da bioconcentração [WEBER, 1982].

A exposição aguda a dioxinas causa irritação nos olhos, pele e trato respiratório. [United Nations, 1985]. Os riscos de contaminação por vias indiretas, ingestão e contato pela pele, excede a via de inalação direta segundo estudos de riscos revisados em Levin et al. [LEVIN, 1991] apesar da U.S.EPA considerar a inalação como via primária. [TRAVIS, 1989].

Apesar de não haver estudos de exposição humana unicamente a dioxinas, como já citado, estudos com animais e relatos de acidentes onde a exposição às dioxinas foi elevada permitem relacionar cloracne, câncer de figado, alopepcia, "porphyria cutanea tarda", uroporphyrinuria, neuropatia periférica, entre outros, como sintomas da contaminação. Estudos em animais permitem estimar que TCDD é um cancerígeno não genotóxico [EPA CFR401.15, 7/1/88]. A ação das dioxinas é prototípica de hidrocarbonetos policíclicos halogenados. [STOHS, 1990]. Stohs afirma ainda que a TCDD é uma das mais potentes toxinas e promotores de tumores conhecidos do homem.

De acordo com a US EPA, estudos de efeitos de dioxinas em pessoas rendem resultados inconsistentes - de nenhum a alto risco. Desta forma a US EPA decidiu utilizar modelos preditivos para estimar o risco humano a níveis de exposição ambiental. Dowd cita três modelos em discussão nos EUA que conduzem a níveis aceitáveis de ingestão diária de $0,006 \mathrm{pg} / \mathrm{kg} / \mathrm{dia}, \quad 0,6-1,0 \quad \mathrm{pg} / \mathrm{kg} / \mathrm{dia} \quad$ e $\quad 1,0-10,0 \quad \mathrm{pg} / \mathrm{kg} / \mathrm{dia}$, respectivamente.[DOWD, 1988]. Um limite ocupacional preliminar de $0.2 \mathrm{ng} / \mathrm{m} 3$ (200 
$\mathrm{pg} / \mathrm{m} 3$ ) é recomendado devido à incerteza quanto a outras fontes de exposição a TCDD, quanto a seu mecanismo de ação e quanto a sua meia vida em seres humanos. [?, CFR 1988]. Seguindo o mesmo raciocínio, a U.S.EPA classifica a 2,3,7,8 TCDD como cancerígeno classe B2 baseada em 'evidência inadequada em humanos e evidência suficiente em animais' o que indica, pela definição desta classe, 'provavelmente cancerígeno para humanos' [USEPA, 1988 Methodogy....]

Um dos parâmetros importantes na avaliação dos riscos ambientais e à saúde humana é a meia vida de permanência de um contaminante em determinado meio ou organismo. A partir deste dado é possível estimar a exposição humana ou animal por múltiplos meios e traçar a cadeia do contaminante. Para as dioxinas existem diversas estimativas algumas das quais resumidas no quadro abaixo:

Tabela 5.8 - Meia Vida das Dioxinas em diversos meios

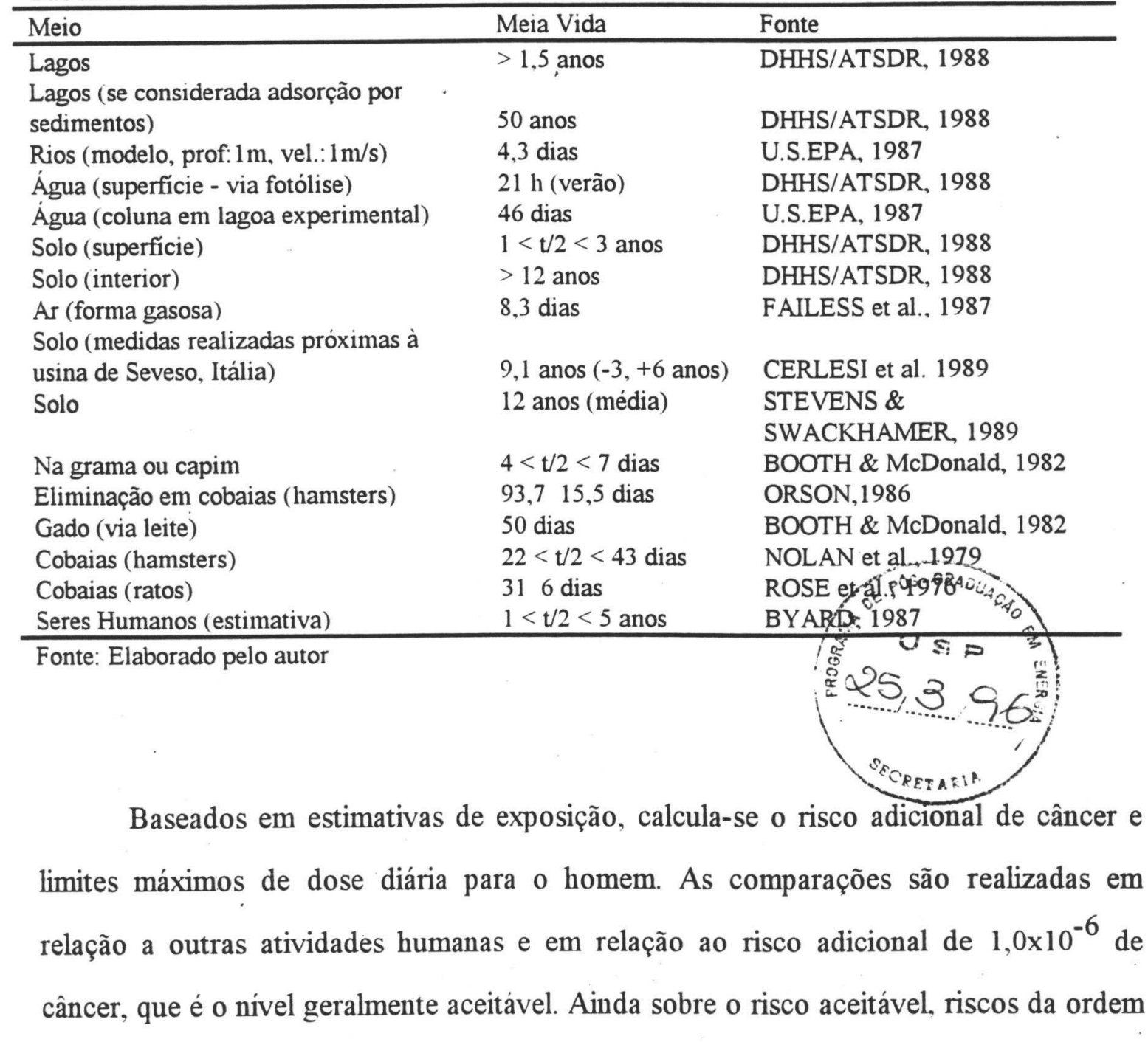


de $10^{-6}$ a $10^{-7}$ são admissiveis pelo esquema atual da U.S.EPA apesar de riscos superiores a $1,0 \times 10^{-6}$ já não serem aceitos na Califórnia. [LEVIN et al., 1991]. A partir destes riscos, através de modelos se estima a dose máxima de ingestão diária. Neste ponto surgem grandes divergências dos técnicos. Dowd cita três modelos em discussão nos EUA que conduzem a valores de $0,006 \mathrm{pg} / \mathrm{kg} / \mathrm{dia}, 0,6-1,0 \mathrm{pg} / \mathrm{kg} / \mathrm{dia}$ e $1,0-10,0$ $\mathrm{pg} / \mathrm{kg} /$ dia, respectivamente [DOWD, 1988]. Curtis, Holly e Hattmemer afirmam que, considerada a dose diária, já recebida pela população americana, o risco de cancer é de $1,0.10^{-4}$ durante a vida de um americano. Este valor contrasta significativamente com o reconhecido pela EPA..

\subsubsection{Furanos}

A literatura, tão extensa quando relacionada a dioxinas, é ainda reduzida quanto a furanos. Muitos dos estudos, quando tratam de furanos, compreendem também as dioxinas. As substâncias chamadas de furanos perfazem um total de 135 isômeros [W+E, 1990] com ocorrência natural ou sintetizados pelo homem. A figura 5.5 abaixo apresenta a fórmula mínima e representação gráfica dos furanos. Eles se distingüem das dioxinas por uma ligação simples adicional entre os anéis benzênicos.

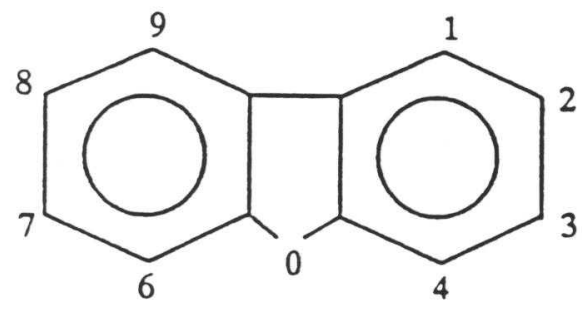

Fórmula mínima $\mathrm{C}_{12} \mathrm{H}_{4} \mathrm{OCl}_{4}$

PCDFs

Figura 5.5 - Representação de Furanos e fórmula mínima dos TCDF

A temperatura ambiente os furanos estão no estado líquido, possuem ponto de ebulição a 32 C (758 mmHg) e ponto de solidificação a -85 C. Caracteriza-se por possuir um valor extremamente baixo de $\operatorname{logKow}(\operatorname{logKow}=1,34)$ o que indica uma boa 
solubilidade em éter e benzeno, mas com baixa solubilidade em água. $\mathrm{O}$ seu potencial tóxico é avaliado em equivalente de 2,3,7,8 TCDD uma vez que, na maioria dos casos de emissões de furanos, existe a presença de dioxinas, particularmente no caso de incineradores de RSU.

Furanos podem ser obtidos do óleo de destilação de madeira de pinho e foi identificado como um componente volátil de "sorbtrees". Também foram detectados furanos na fumaça de cigarros [KIRK-OTHMER, 1985], nos fumos da queima de madeiras, na exaustão de motores e até como componente volátil em avelãs torradas [KINLIN, 1972]. Uma das fontes importantes de emissão são as próprias fábricas de produção ou nos locais de uso destes produtos.

Se lançado à terra os furanos estão susceptíveis a volatização rápida e lixívia significativa, possivelmente atingindo o lençol freático. Não se considera a hidrólise química como importante reação de destruição. Se lançado à água, volatização e reação com o oxigênio dissolvido são processos potenciais de degradação. Não se espera que os furanos venham a se hidrolizar, bioacumular em organismos aquáticos ou serem adsorvidos em quantidades significativas por sólidos em suspensão e sedimentos. Se lançados ao ar, os furanos existirão praticamente na fase vapor. Pode ser decomposto por reações com radicais hidroxil durante as horas do dia $(\mathrm{t} / 2=6 \mathrm{~h})$ e, durante o período noturno, por reações com radicais nitrato $(\mathrm{t} / 2=0,5 \mathrm{~h})$.

Os furanos são venenosos se inalados ou absorvidos pela pele. Seus vapores causam náuseas e sufocação. Irrita e queima a pele e olhos [Dept. Transp., 1987] e provocam queda da pressão sangüínea. Os danos permanentes são causados ao figado.

A forma mais provável de exposição humana é por inalação. Considera-se que os furamos são prontamente absorvidos por esta via. Em bebês pode ser considerada a ingestão, pois foi detectado furano no leite materno. Furanos foram ainda detectados no ar expirado por fumantes e não fumantes em taxas variando entre $0-98 \mathrm{~g} / \mathrm{h}$ e 0-28 g/h respectivamente. 


\subsection{3 - Emissões em Incineradores de RSU}

Apesar de estar comprovado que incineradores de RSU e de produtos químicos são fontes importantes de emissões de dioxinas e furanos, ainda não existe uma certeza com relação à origem das dioxinas e furanos emitidos por incineradores. A tabela 5.9 abaixo relaciona as emissões medidas em alguns dos incineradores em operação e já desativados. Dentre as fontes de dioxinas possiveis destacam-se [W+E, 1990 e VISALLI, 1987]:

- Existência prévia nos resíduos;

- Produção (síntese) devido ao processo de incineração, ie, devido à incineração incompleta de compostos organo-clorados;

- Recombinação, causada pela presença de íons cloreto, nas partes frias (200-400 C) do sistema.

Tabela 5.9 - Concentrações de Dioxinas medidas em incineradores

\begin{tabular}{|c|c|}
\hline Diversas usinas na Europa e EUA & $0,05-3,5 \mathrm{ng} / \mathrm{Nm}^{3(\mathrm{a})}$ \\
\hline 3 Usinas Inc. Alemanha & $<0,02-0,7 \mathrm{ng} / \mathrm{Nm}^{3}(\mathrm{~b})$ \\
\hline 2 Usinas Inc. Bélgica & $0,97-3,8 \mathrm{ng} / \mathrm{Nm}^{3}(\mathrm{c})$ \\
\hline 9 Usinas Inc. Japão(particulado) & $\begin{array}{l}0,1-5,4 \mathrm{ng} / \mathrm{Nm}^{3} \text { (d) } \\
<0,01-1,3 \mathrm{ng} / \mathrm{Nm}^{3} \text { (d) }\end{array}$ \\
\hline Incinerador de Florença Itália & $100-1000 \mathrm{ng} / \mathrm{Nm}^{3}(\mathrm{e})$ \\
\hline
\end{tabular}
(a) (ATSDR/TP-88/23 (1988))
(b) Ballschinter, K. et al. Chemosphere 13:1139-42 (1984)
(c) Defre, R. Chemosphere 15:1255-60 (1986)
(d) Wakimoto T., Tatsukawa, R. Environ. Health Persp. 59:159-62 (1985)
(e) Esta usina foi construida em 1973 e fechada em 1985 após a publicação destas emissões BERLINCIONI, 1987

A existência prévia nos resíduos não pode ser controlada além de se evitar a queima de produtos químicos com contaminação potencial (clorobenzenos, clorobenzóis, etc). Como estes produtos necessariamente não devem ser coletados juntamente com os resíduos domésticos ou comerciais, espera-se uma presença mínima de dioxinas e furanos no resíduo recebido pela usina.

A sintese durante a queima ou em etapas de resfriamento e tratamento dos gases de exaustão representa a maior quantidade gerada de dioxinas e furanos [VISALLI, 1987] e pode ser controlada. Diversos estudos se dedicaram à determinação das 
condições de formação e destruição ou controle das dioxinas e furanos entretanto, modelos detalhados de cinetica química de alguns compostos estão sendo ainda elaborados [TAYLOR 1990]. Estudos em ampolas fechadas determinaram que entre a formação ocorre na faixa 550-650 C e a destruição aparente ocorre em temperaturas acima de $700 \mathrm{C}$. Em estudos reproduzindo condições encontradas em incineradores de escala comercial, concluiu-se que existe uma relação sinergística entre a concentração de oxigênio e temperatura na conversão de PCB em dos furanos. Encontrou-se um máximo de conversão próximo de $675 \mathrm{C}$ e $8 \%$ de oxigênio, para períodos de residência entre 0,8 e 1,5 segundos [ERICSON, 1989].

A figura 5.6 colocada abaixo mostra a curva teórica de formação e destruição de clorofenóis, substâncias similares às dioxinas e furanos. Apesar de não serem idênticos os valores, a forma da curva permanece a mesma para as PCDD e PCDF.

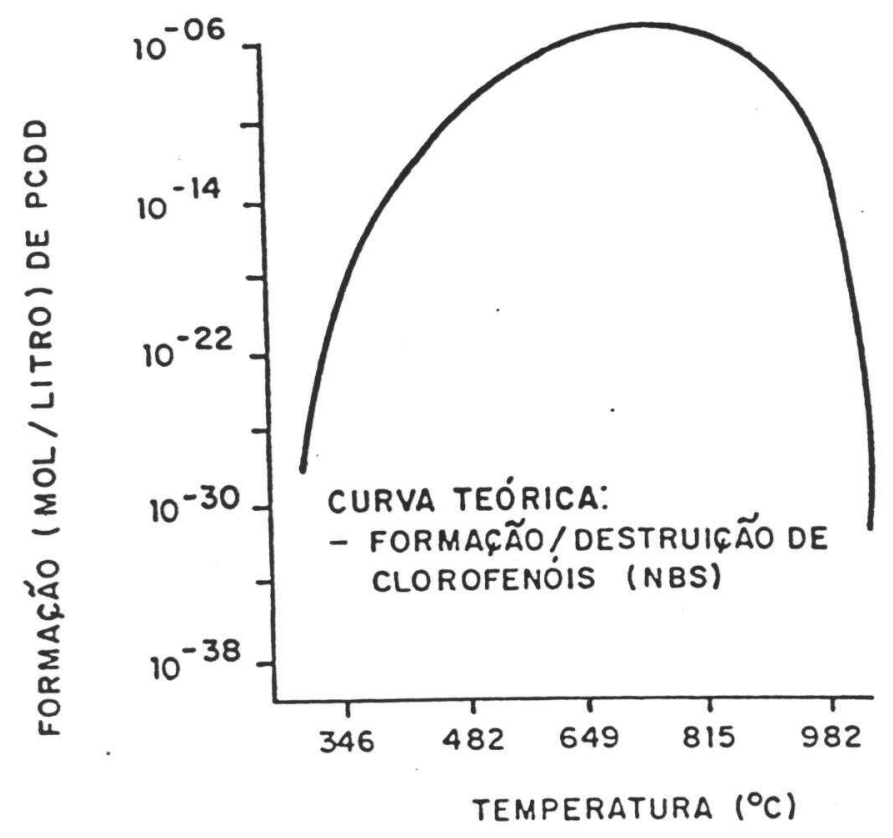

Figura 5.6 - Curva teórica de formação e destruição de clorofenóis. fonte: TECHNOPLAN, 1991.

Quanto à destruição de compostos orgânicos em geral. existe um escala 
de estabilidade elaborada baseando-se na premissa de que, quanto mais baixo o calor de combustão, mais dificil é a combustão do composto. Esta escala, seguida pela USEPA sofre severas críticas teóricas uma vez que resultados em laboratórios não conseguem reproduzi-la. Cálculos e experiências levam a crer que a destruição dos principais compostos orgânicos perigosos, incluindo ai as PCDD e PCDF, são controlados cineticamente e não termodinâmicamente. A destruição em incineradores é controlada por fatores de cinética química como temperatura, atmosfera de reação (oxidante, redutora) e tempo de residência [TAYLOR, 1990]. Taylor elaborou uma escala baseada em experimentos e modelos de cinética química. Neste trabalho apresentou ainda o gráfico de decomposição térmica para uma mistura de compostos orgânicos que está reproduzido na figura 5.7 abaixo. Espera-se que as PCDD e PCDF possuam comportamento similar com decomposição mais rápida do que a do naftaleno. As curvas apresentadas na figura 5.8 confirmam esta afirmação.

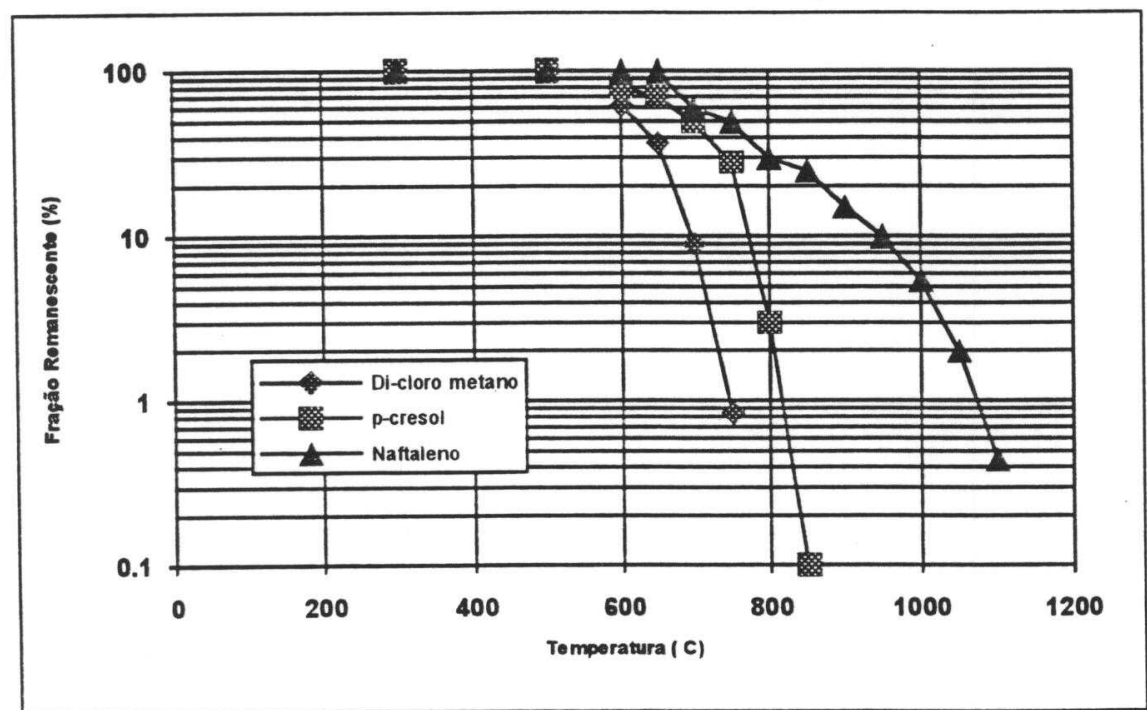

Figura5.7 - Curva de decomposição térmica para uma mistura de três compostos perigosos.(log Fração restante (\%) x temperatura C) Fonte: TAYLOR, 1990. 


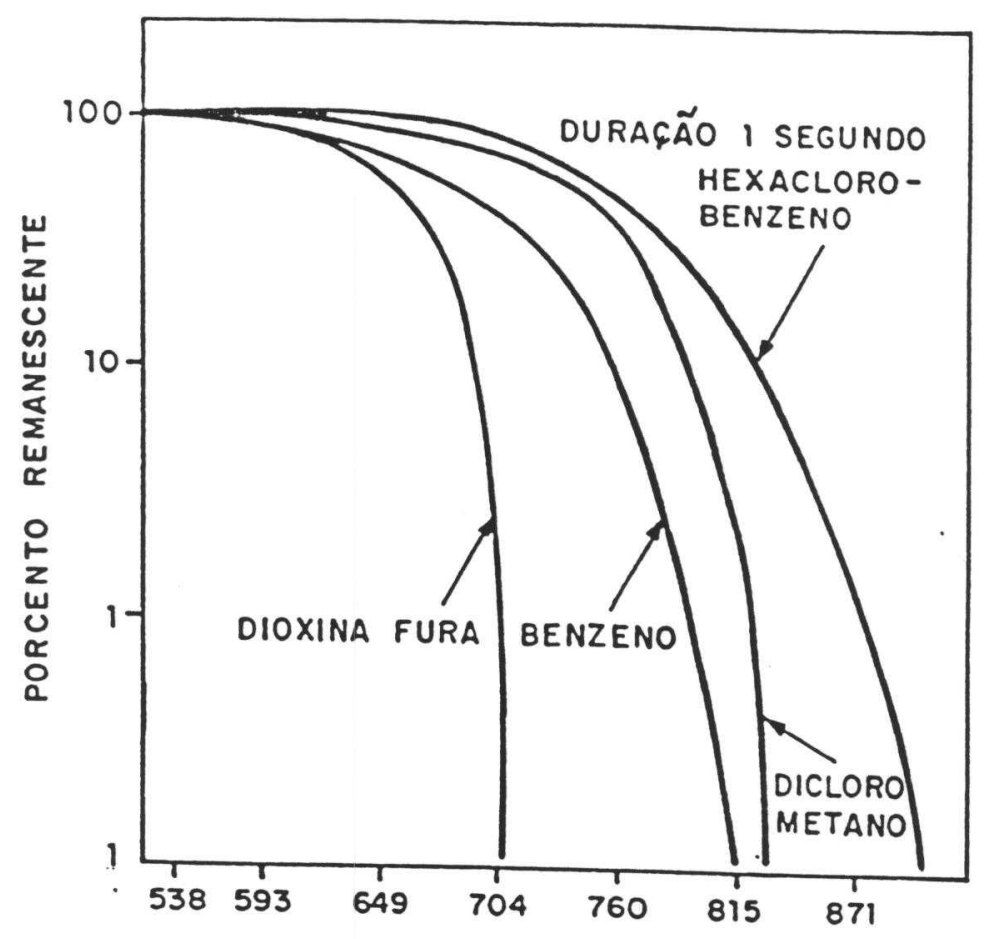

Figura 5.8 - Curva de decomposição térmica Fonte: TECHNOPLAN, 1991.

Hagenmaler et al. concluiram que mesmo a completa destruição de PCDD, PCDF e outros compostos organoclorados na câmara de combustão não garante a ausência destes nas cinzas de filtro devido à possível re-síntese nas regiões de resfriamento do incinerador. Esta re-síntese pode ser devido a efeito catalítico $(\mathrm{Cu}, \mathrm{Rh}$ e $\mathrm{Pt})$ na reação de de-cloração / hidrogenação de PCDD/PCDF. Este efeito ocorre na faixa de $300 \mathrm{C}$ sendo direcionado para a de-cloração / hidrogenação em atmosfera pobre de oxigênio e para a re-síntese em condições de excesso de oxigênio. Os autores afirmam que este efeito pode ser utilizado na descontaminação de cinzas de incineradores sendo necessário um tratamento térmico adicional com baixos custos de investimento e operação. [HAGENMALER, 1987 (a)]. Em outro artigo, os autores analisam mais profundamente o efeito catalítico do cobre sobre a reação de decloração/hidrogenação em temperatura na faixa de $300 \mathrm{C}$. Esta temperatura pode chegar a $120 \mathrm{C}$ (testada) mas o tempo necessário para redução a $3 \%$ da concentração inicial é de aproximadamente $20 \mathrm{~h}$. Para a faixa de temperatura próxima de $285 \mathrm{C}$, o aquecimento por 1 minuto é suficiente para 
destruição de 99\% dos compostos. [HAGENMALER, 1987 (b)].

Visalli [VISALLI, 1987] relata testes realizados em incineradores em operação indicaram que $99,99 \%$ (em peso) das dioxinas e furanos não cloradas estariam destruídas em temperaturas de aproximadamente $760 \mathrm{C}$ e tempo de residência próximos de 1 segundo. Para compostos clorados testes similares indicam o mesmo resultado para temperaturas superiores a $815 \mathrm{C}$. Sobre a influência do excesso de oxigênio, o mesmo estudo não obteve resultados comparáveis nos três incineradores testados concluindo que este parâmetro deve ser analisado individualmente segundo as características de cada tipo de incinerador e controle de combustão, entretanto os resultados permitem inferir que excesso de oxigênio inferior a $5 \%$ podem causar um aumento nas concentrações de dioxinas e furanos. Da mesma forma o estudo não conseguiu determinar uma correlação entre níveis de $\mathrm{CO}$, concentração de $\mathrm{HCl}$ ou quantidade de $\mathrm{PVC}$ nos resíduos e emissão de dioxinas/furanos. O nível de CO passa a ser um indicador quando este nível excede o normal por um fator de 10 e acima. De uma forma geral, foram encontrados níveis de concentração de furanos sempre superiores aos de dioxina indicando que estes seriam ou mais fáceis de formar, ou mais dificeis de destruir do que as dioxinas.

Outro trabalho experimental em incinerador de escala real conseguiu obter uma correlação entre emissões de dioxinas e a quantidade de material particulado e entre emissões totais de PCDD e PCDF e concentração de CO. A figura 5.9 colocada abaixo mostra uma alta correlação exitstente entre o material particulado total e a concentração de dioxina no precipitador eletrostático $\left(\mathrm{r}^{2}=0.899\right)$. É citado ainda neste trabalho que existe evidência substancial que a "re-síntese" de dioxinas e furanos ocorre na superficie das cinzas (flyash) a temperaturas entre 250 C e $400 \mathrm{C}$ com formação máxima em temperaturas próximas de 300 C. Esta evidência suporta as normas de operação de incineradores de RSU que especificam uma temperatura máxima de $230 \mathrm{C}$ na entrada do dispositivo de controle de particulados [BRNA, 1990]. A importância do controle de CO para a minimização de emissões de dioxinas e furanos mostrada na figura 5.10. 


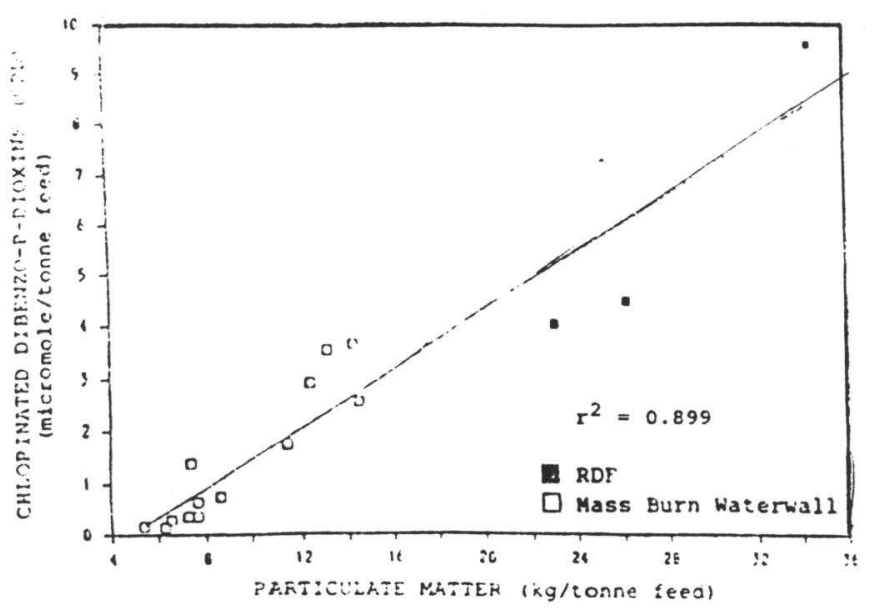

Figura 5.9 Dependência da emissão de PCDD na emissão de material particulado Fonte: BRNA, 1990.

As figuras acima confirmam conclusões de outros trabalhos que serviram de base para que a USEPA elaborasse, em 1989, normas regulatórias para incineradores de RSU. Dentre estas normas está a implementação da chamada Práticas de Boa Combustão (Good Combustion Practices - GCP) que envolve o projeto adequado, construção, operação e manutenção de um incinerador. A adoção destas práticas resultam em

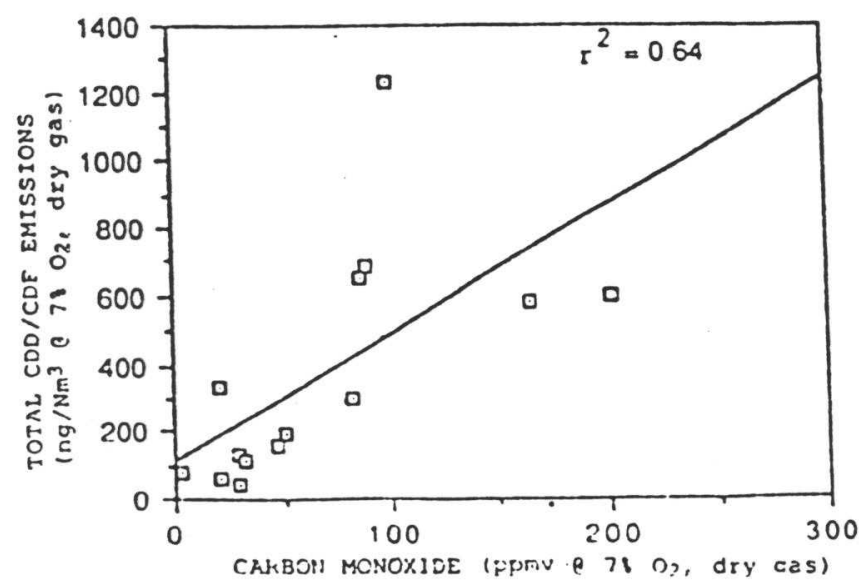

Figura 5.10 -Emissões totais de PCDD/PCDF como função da concentração de CO, ambos medidos na saída do precipitador eletrostático do incinerador de Quebec City. Fonte: BRNA, 1990. 
Tabela 5.10 - Limites para emissões de dioxinas em 2,3,7,8 equivalente

\begin{tabular}{|c|c|c|c|c|}
\hline $\begin{array}{l}\text { CE } \\
1989 \\
\text { (novas usinas) }\end{array}$ & $\begin{array}{l}\text { Alemanha } \\
1990\end{array}$ & $\begin{array}{l}\text { Holanda } \\
1989\end{array}$ & $\begin{array}{l}\text { Suécia } \\
1987 \\
\text { (novas usinas) } \\
\end{array}$ & $\begin{array}{l}\text { Inglaterra } \\
1993 \\
\text { (a) } \\
\end{array}$ \\
\hline $0,1 \mathrm{ng} / \mathrm{Nm}^{3}$ & $0,1 \mathrm{ng} / \mathrm{Nm}^{3}$ & $0,1 \mathrm{ng} / \mathrm{Nm}^{3}$ & $0,1 \mathrm{ng} / \mathrm{Nm}^{3}$ & $1,0 \mathrm{ng} / \mathrm{Nm}^{3}$ \\
\hline
\end{tabular}

Fonte: JUNGMANN, 1993 - equivalente tóxico EADON (exceto Alemanha e Holanda=NATO)

(a) KOWLES, 1993. - equivalente tóxico NATO/CCMS

redução das emissões de poluentes. Foram fixados limites para emissão de CO, capacidade de carga e temperatura máxima dos gases na entrada do equipamento de controle de particulados $(230 \mathrm{C})$ de forma a minimizar a "re-síntese" de dioxinas e furanos. $\mathrm{O}$ controle da combustão é realizado de forma a permitir uma temperatura dos gases superior a $1000 \mathrm{C}$ durante 1 a 4 segundos. Adicionalmente exigiu-se o treinamento e a certificação dos operadores pela ASME [JOHNSTON, 1990].

Estas práticas, aplicadas na construção de novos incineradores e na reforma de usinas em operação surtem grandes efeitos no controle das emissões de PCDD e PCDF. Paralelamente, o desenvolvimento de dispositivos de controle ativo é permanente. Alguns destes dispositivos já existiam na prática uma vez que já foi provado que a remoção de dioxinas e furanos em um lavador de gases ácidos é paralela à de metais pesados, como cita Brna [BRNA, 1990]. Neste artigo de 1990 Brna cita inda que esta remoção parece ser auxiliada pela presença de absorventes calcáreos. Confirmando esta hipótese, a modificação, em 1991 da usina de incineração de RSU de Zirndorf que emitia 8 ng/Nm 3 resultou em um novo índice de emissão de $0,0059 \mathrm{ng} / \mathrm{Nm}^{3}$. Foi adotado um novo processo chamado de filiabsorção ( filtragem + absorção), descrito no próximo item.

Estas experiências se repetem em outras usinas onde novas tecnologias e práticas corretas de operação têm possibilitado a queima de RSU com níveis controlados de emissões de PCDD e PCDF. Estes esforços são resposta a normas cada vez mais rígidas de emissões. A tabela 5.10 ilustra as normas atualmente vigentes na Comunidade Européia. É importante ressaltar que os incineradores em projeto ou construção atualmente atendem com relativa folga estas normas apesar do alto potencial de emissão ilustrado nas tabelas 5.3 e 5.9 . 


\subsection{Sistemas de tratamento de efluentes gasosos}

Existem inúmeras tecnologias para o controle de emissões, desde as mais simples como simples câmaras de passagem até complexos sistemas que incluem injeção de reagente na câmara de combustão, recirculação de gases, etc. A adoção de determinada tecnologia ou sistema de tratamento está vinculada a critérios como estimativa de carga de poluentes, características fisico-químicas destes e, principalmente, das exigências legais ou limites de emissões impostos pela legislação. Este limite é na verdade o fator decisivo na adoção de determinado sistema de tratamento de gases. A tabela 5.11 abaixo mostra claramente que o potencial de emissão é alto mas normas rígidas como a holandesa é capaz de ser satisfeita uma vez que existem usinas em implantação e construção naquele país.

Nos últimos anos, com o aumento da pressão ambientalista, forçou-se um desenvolvimento acelerado das pesquisas e de produtos nesta área. No caso de incineradores, a preocupação com relação emissão de dioxinas, furanos e metais pesados tem sido o ponto decisivo quanto adoção (ou rejeição) até mesmo de tecnologias de incineração. Com a sofisticação dos sistemas, o custo das usinas de incineração aumentou significativamente, comprometendo muitas vezes a operação

Tabela 5.11 - Comparação de concentração de poluentes no gás bruto e limites de emissão.

\begin{tabular}{lcc}
\hline & $\begin{array}{l}\text { Holanda } \\
\text { legislação 1989 } \\
\text { (período= hora) } \\
11 \mathrm{~V} \% \text { O2 }\end{array}$ & $\begin{array}{l}\text { Valores típicos do gás bruto de } \\
\text { incineração de RSU depois da } \\
\text { caldeira de recuperação }\end{array}$ \\
\hline Particulado total & 5 & $1000-5000$ \\
$\mathrm{HCl}$ & 10 & $600-1200$ \\
$\mathrm{SO} 2$ & 40 & $100-600$ \\
$\mathrm{HF}$ & 1 & $200-600$ \\
$\mathrm{NOx}$ & 70 & $0.1-0.6$ \\
$\mathrm{Hg}$ & 0.05 & $5-30$ \\
$\mathrm{Cd}$ & - & \\
Outros Metais & 1.0 & \\
NH3 & - & $200-1200$ \\
Equivalente TCDD & 0.1 & \\
\hline Total & (EADON) & \\
\hline
\end{tabular}

Valores em mg/Nm3; para TCDD ng/Nm3; seco

Fonte: JUNGMANN, 1993 
Quanto ao sistema de controle de gases ácidos a dúvida recai sobre os reatores secos (RS), reatores semi-secos (RsS) e os reatores úmidos (RU). Uma revisão dos processos é realizada na edição de julho de 1986 da revista POWER. A escolha entre estas tecnologias também é bastante debatida entre especialistas [MAKANSI, 1987]. Os custos considerando todo o ciclo de vida são equivalentes se realizada uma normalização baseada em dólares por tonelada de contaminante removido [MAKANSI, 1987].

Sistemas de reatores secos continuam a ser preferidos para controle de poluentes emitidos por incineradores de RSU nos EUA. Apesar de reatores secos objetivarem o controle de $\mathrm{SO}_{2}$ e $\mathrm{HCl}$, eles também retiram metais pesados e poluentes orgânicos. A remoção de PCDD/PCDF é paralela a dos metais pesados, mas acredita-se que seja acelerada pela presença de absorventes calcáreos. [BRNA,1990].

Os RS possuem como resíduo um produto totalmente seco, o que é considerado uma vantagem, apesar de que alguma água tem que ser adicionada antes do transporte ao local de deposito final. Os RS possuem uma eficiência menor de absorção do que os RsS e RU, mas atingem os mesmos índices de remoção através de um maior consumo de reagente [MAKANSI, 1987].

Uma tecnologia recente que tem recebido bastante aceitação é a injeção de adsorvente seco para controle de gases ácidos. A idéia aqui é usar um reagente altamente reativo no gás de exaustão permitir que as reações de adsorção ocorram e coletar os sólidos em um FS. Apesar de se fornecer comprimento suficiente nos dutos para a reação, muitos especialistas acreditam que a maior parcela da reação se realiza já nos sacos do filtro. As desvantagens deste processo que é o maior consumo de reagente e menor eficiência de remoção de alguns metais - especialmente o mercúrio - e de compostos orgânicos devido temperatura em que se realiza o processo. Estas desvantagens são em parte compesadas pela simplicidade e baixo custo desta alternativa. [MAKANSI, 1987].

Existem ainda outros processos desenvolvidos recentemente com um grande potencial de utilização. Entre estes podemos relacionar a injeção de carbonato de sódio 


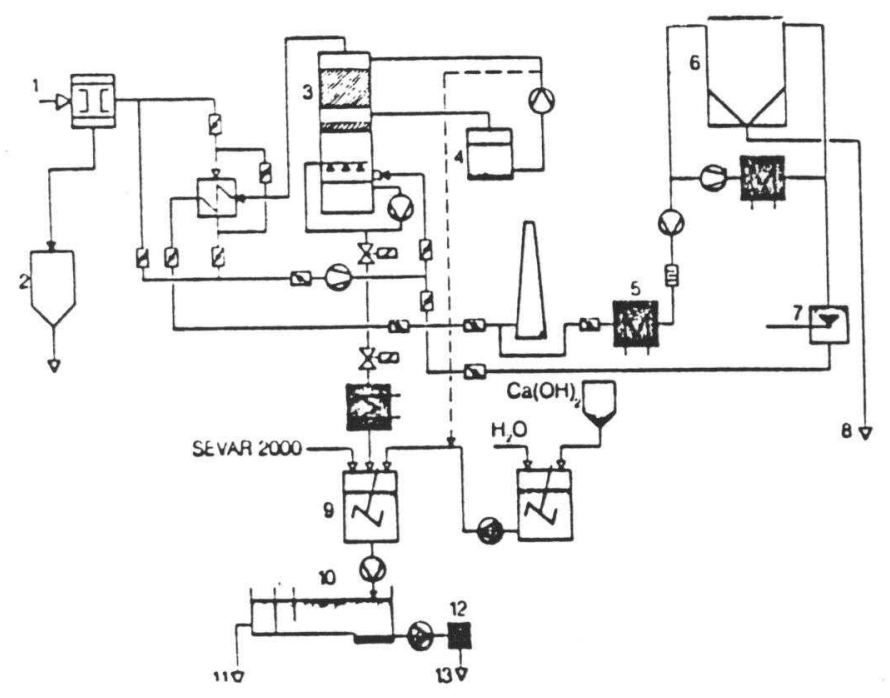

1 Da caldeira

2 Silo de cinzas

3 Lavador de Gases Úmido com remoção de $\mathrm{SO} 2$

4 Tanque de recirculação

5 Reaquecedor

6 Filtro de Tecido

7 Injeção de "sorbalit"

8 para o Incinerador

9 Neutralização

10 Tanque de precipitação

11 Águra residual

12 prensa de lodo

13 Residuo de filtragem

Figura 5.11 - Sistema de tratamento de gases com processo "filsorption" fonte: JUNGMANN, 1993. figura 2

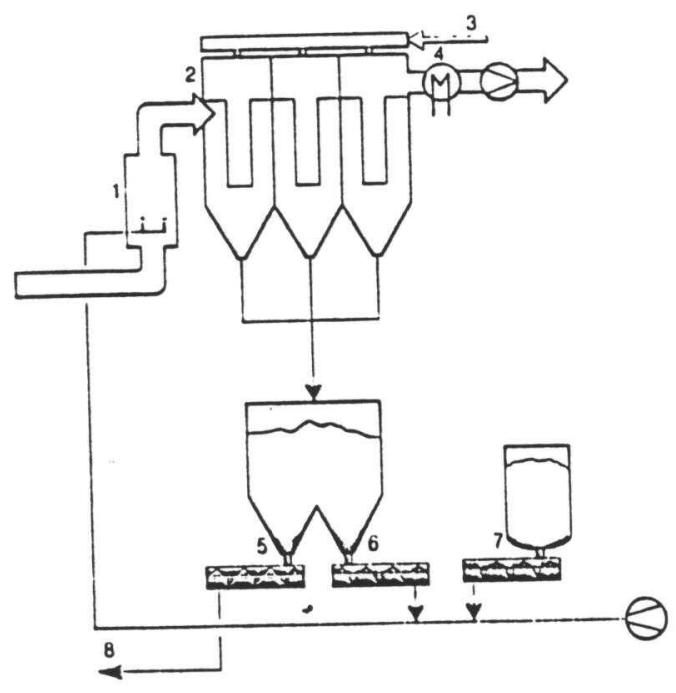
Reator compacto
2 Filtro de sacos de tecido
3 Ar comprimido
4 Trocador de calor
5 Produto residual
6 Produto para recirculação
7 "sorbalit"
8 para o Incinerador

Figura 5.12 - Estágio "filsorption" para controle de dioxinas e furanos fonte: JUNGMANN, 1993. figura 3 


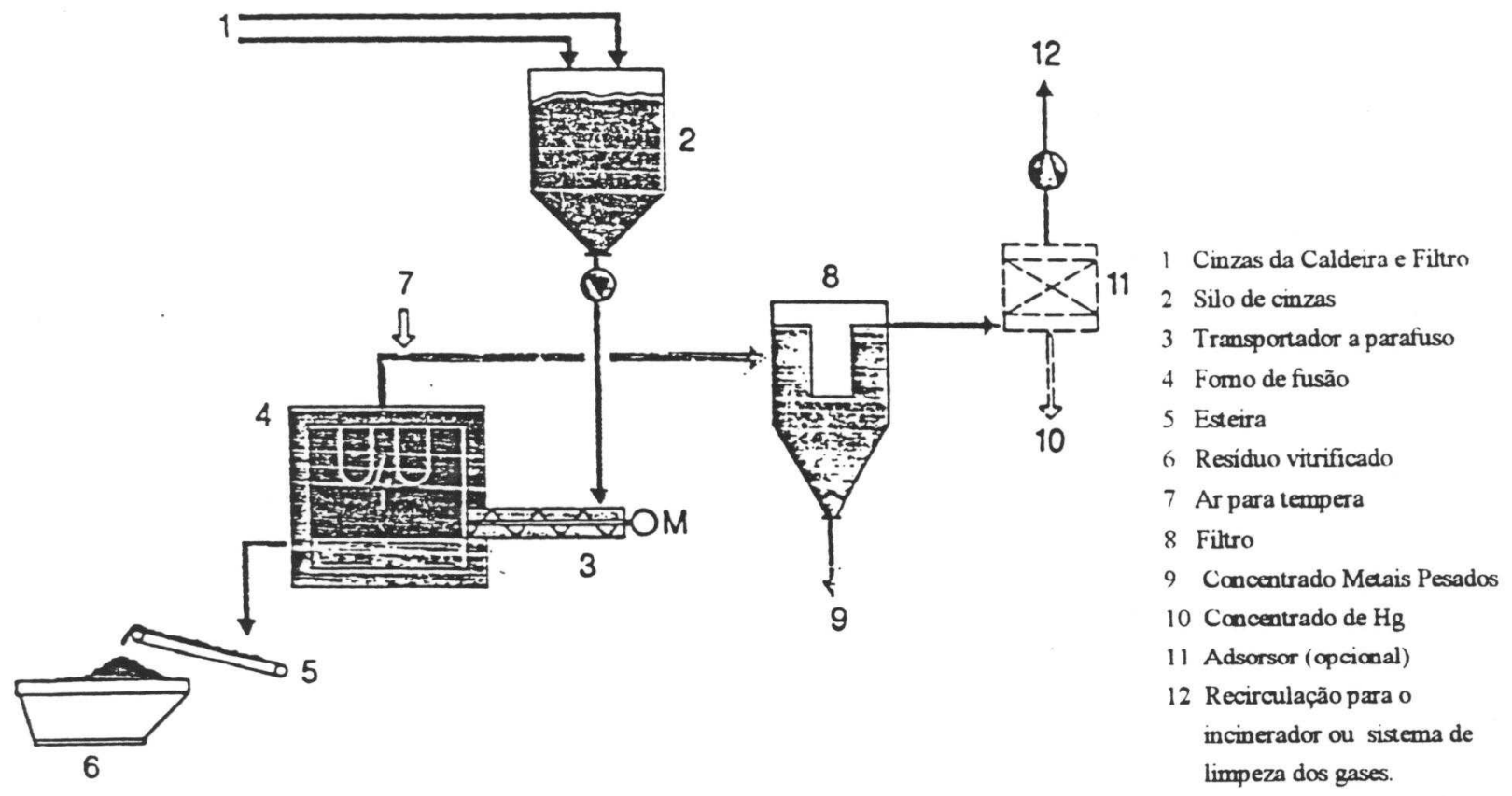

Figura 5.13 Processo DEGLOR para descontaminação, vitrificação e recuperação de metais das cinzas de filtros.

Fonte: JOCHUM. 1991. 


\section{Capítulo 6}

\section{A Opção de Incineração no ABCD}

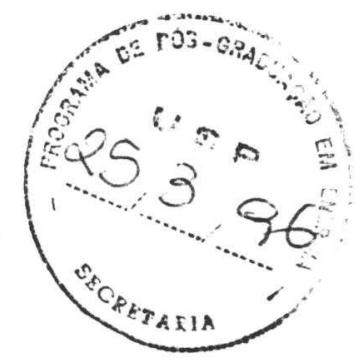

Nos capítulos anteriores apresentou-se a região do $\mathrm{ABCD}$, seus problemas de resíduos e descreveu-se as tecnologias de gerenciamento de RSU disponíveis atualmente dando ênfase, através de uma revisão do estado da arte, às tecnologias de incineração. Discutiu-se também as emissões atmosféricas resultantes da queima dos RSU em incineradores. A partir dos dados apresentados, elabora-se neste capítulo um estudo da opção de incineração como forma de tratamento de RSU na região do $\mathrm{ABCD}$. Este estudo permitirá analisar a atratividade desta opção que, caso confirmada positiva, deverá ser avaliada em um estudo completo de viabilidade econômica que contemple as outras alternativas.

A região do $\mathrm{ABCD}$ apresenta hoje problemas de destinação dos seus residuos e possui uma perspectiva de ter esgotada sua capacidade de tratamento e destinação em futuro breve. Dada a expansão urbana e às características do ecossistema local, o principal problema é a escassez de novas áreas para aterro. Ainda existem algumas áreas disponiveis como mencionado no capítulo 3 , mostrado no mapa colocado como apêndice. Estas áreas entretanto são poucas e são as últimas em toda a região. No caso do esgotamento destas ou inviabilizadas pela expansão da mancha urbana, as alternativas localizam-se a distâncias superiores a $30 / 40 \mathrm{~km}$ (exitem algumas áreas em Itaquecetuba) o que oneraria sobremaneira o transporte dos resíduos. Esta opção entretanto esbarra na aceitação dos resíduos pelos outros municípios. Conforme discutido no capítulo 4. a opção de incineração permitiria aumentar a vida útil dos aterros da região por aproximadamente dez vezes mais. 


\section{1 - Aspectos Gerais}

No capítulo 1 desta dissertação foi estimada a população da região do $\mathrm{ABCD}$. Baseando-se em valores de produção per capita de resíduos sólidos urbanos próximos às do município de São Paulo hoje, dado que o crescimento da região caminha em direção a características semelhantes do polo principal da região metropolitana, pode-se elaborar previsões da quantidade de RSU a serem tratados no ano de 2010. Estas previsões são apresentadas na tabela 6.1 abaixo.

Tabela 6.1 - Previsões das quantidades de RSU nos municípios do ABCD em 2010

\begin{tabular}{|c|c|c|c|c|c|}
\hline \multirow[b]{2}{*}{ Municipio } & \multirow[b]{2}{*}{$\mathrm{Kg} / \mathrm{hab}^{1}$} & \multicolumn{4}{|c|}{ RSU em 2010 (tpd) } \\
\hline & & $\begin{array}{c}\text { Hipótese } \\
\text { Baixa } 1\end{array}$ & $\begin{array}{c}\text { Hipótese } \\
\text { Altal }\end{array}$ & $\begin{array}{c}\text { Hipótese } \\
\text { Baixa }^{2} \\
\end{array}$ & $\begin{array}{c}\text { Hipótese } \\
\text { Alta }^{2} \\
\end{array}$ \\
\hline Diadema & 0,91 & 336 & 406 & 332 & 400 \\
\hline Maua & 0,64 & 227 & 274 & 320 & 386 \\
\hline Ribeirão Pires & 0,64 & 66 & 79 & 92 & 111 \\
\hline Rio Grande da Serra & 0,74 & 27 & 32 & 32 & 39 \\
\hline Santo Andre & 0,81 & 602 & 725 & 669 & 806 \\
\hline São Bernardo do Campo & 1,03 & 707 & 852 & 605 & 729 \\
\hline São Caetano do Sul & 1.16 & 208 & 251 & 162 & 196 \\
\hline Total & 0.88 & 2173 & 2620 & 2213 & 2068 \\
\hline
\end{tabular}

1 - Segundo EMPLASA, 1993

2 - Elaborados com dados de FILSAN, 1992 e assumindo $0,9 \mathrm{~kg} /$ (hab.dia) e taxas de crescimento populacional de $1 \%$ e $2 \%$.

Os valores apresentados na tabela acima representam todo o RSU gerado na região do $A B C D$ e que deve receber uma destinação final adequada pelas municipalidades. Comparativamente às quantidades geradas em 1991, apresentadas nas tabelas 3.1 e 3.2 , estas estimativas representam um aumento superior a $46 \%$. No capitulo 2 afirma-se que a melhor alternativa para a região é a adoção de um programa de gerenciamento integrado de RSU, o qual contemplaria além da incineração, coleta seletiva, reciclagem, compostagem e programas de redução na fonte. Estas ações, se corretamente planejadas e gerenciadas, reduziriam a quantidade a ser incinerada e, principalmente, a quantidade destinada aos aterros. O possível impacto de um programa de reciclagem sobre a quantidade de RSU é mostrado na tabela 6.2. As metas de 
reciclagem mostradas na tabela 6.2 baseam-se em programas de reciclagem existentes em países europeus. Para determinação destas metas para o $A B C D$ deve ser realizado um estudo econômico do mercado potencial para os produtos da compostagem e reciclagem. Considerando o potencial atual de coleta de 1800 tpd, o tamanho de um incinerador para a região deve variar entre 1000 tpd a 2000 tpd, dependendo da adoção de um programa de reciclagem e compostagem mais intenso. Adota-se, para efeito de cálculo nesta dissertação, uma usina de 1200 tpd. Esta capacidade é capaz de atender a demanda atual e pode ser suficiente por um período maior no futuro dependendo da adoção de medidas como programas de redução na fonte e reciclagem. Como segurança deve-se prever a expansão da capacidade da usina para 1600 tpd ou 1800 tpd pela adição de mais módulos.

Tabela 6.2- Efeito de programas de Reciclagem sobre a quantidade de RSU.

\begin{tabular}{lcc}
\hline Metas de Reciclagem & & \\
\hline Mat Orgânica & 450 & tpd \\
Papel e Papelao & $50 \%$ & \\
Plasticos & $40 \%$ & \\
Metais & $50 \%$ & \\
Vidros & $70 \%$ & \\
\hline \multicolumn{4}{l}{ Previsões da Quantidade de $R S U$} & \\
\hline 2010 baixa & 2173 & tpd \\
2010 alta & 2620 & tpd \\
2010 baixa c/reciclagem & 1265 & tpd \\
2010 alta c/reciclagem & 1618 & tpd \\
\hline
\end{tabular}

Elaboração do autor.

A escala da usina é importante também para a determinação da magnitude dos problemas relacionados às emissões de poluentes. Penner et al. sugerem que seja dada prioridade a incineradores de maior escala pois estes não só minimizam os custos de controle ambiental como também favorecem a uma menor emissão de poluentes por tonelada incinerada. Incineradores maiores permitem a construção de fornalhas mais amplas, aumentando o tempo de residência dos gases e permitindo a destruição completa dos elementos tóxicos presentes no lixo, bem como dos precursores que podem ser responsáveis pela formação de dioxinas e furanos [PENNER, 1988]. Assim, acredita-se que a adoção de um incinerador de maior escala, que atenda a todas as muncipalidades. é 
mais vantajosa do que a adoção de pequenos incineradores em cada município. Para pontos mais distantes, poderiam ser instaladas estações de transbordo.

Consultando o trabalho da FILSAN, escolheu-se a área AR23 em Mauá para a instalação da usina a ser dimensionada. O local possui $24165 \mathrm{~m}^{2}$ de área útil e foi avaliado em US\$30.700.000. [FILSAN, 1992,Vol. 3, Prod.5, pag.365]. No mapa do apêndice verifica-se que esta é uma área contígua a aterros já existentes ou em projeto e é a área disponível mais afastada da mancha urbana. As áreas contíguas com aterros já planejados somam $146665 \mathrm{~m}^{2}$, o que possibitaria ainda a construção anexa de aterro de cinzas e resíduos não incinerados.

\section{2 - Caracterização dos Resíduos}

O dimensionamento de uma usina de incineração é tarefa bastante arriscada principalmente devido à variabilidade da composição do RSU. Os critérios de projeto são, em sua maioria, empíricos e, desta forma, considerados sigilosos pelos detentores das diversas tecnologias. O dimensionamento é realizado caso-a-caso a partir dos parâmetros físicos e químicos levantados na região. Dada a importância do correto levantamento destes parâmetros do lixo, algumas das empresas fabricantes de usinas fornecem serviços desde o estágio de estudo preliminar.

No caso em estudo, dada a inexistência de todos os parâmetros dos RSU da região, a falta de confiabilidade dos dados existentes, e a inexistência na literatura, de critérios de dimensionamento de usinas, decidiu-se por realizar cálculos preliminares que permitissem a análise das condições de pré-viabilidade da incineração dos RSU na região. Assumiu-se a seguinte composição média para o resíduo, baseando-se em valores médios dos estudos já realizados: 
Estimou-se então o PCI do resíduo a ser incinerado descontando do PCS a quantidade de energia despendida com a vaporização da água presente no resíduo e gerada na combustão. Desta forma, o PCI do resíduo a ser considerado é aproximadamente $11.800 \mathrm{~kJ} / \mathrm{kg} \quad(2.800 \mathrm{kcal} / \mathrm{kg})$. Será realizada uma análise de sensibilidade com relação a este parâmetro.

\section{3 - Queima do Resíduo}

A partir dos dados de composição química colocados acima, determinou-se a fórmula mínima de um composto hipotético que representasse de forma aproximada o resíduo. Esta etapa é necessária para estimativa da quantidade de ar envolvida na combustão bem como na determinação dos produtos gasosos.

A partir da média dos dados existentes para a região permitem estimar a seguinte fórmula para os resíduos (desprezando participações minoritárias).

Fórmula básica do resíduo

$$
\begin{aligned}
& \mathrm{CH}_{1,09} \mathrm{O}_{0,96} \text { (base seca) } \\
& \mathrm{CH}_{4.88} \mathrm{O}_{2.86} \text { (base úmida) }
\end{aligned}
$$

A primeira fórmula química pode ser comparada à da celulose que é a substância de maior presença no RSU.

$$
\mathrm{C}_{5} \mathrm{H}_{10} \mathrm{O}_{5} \quad \mathrm{CH}_{2} \mathrm{O}
$$

Esta redução na presença de $\mathrm{H}$ e $\mathrm{O}$ pode ser atribuída à substituição destes por outros elementos minoritários $(\mathrm{N}, \mathrm{Cl}, \mathrm{S}$, etc) e às insaturações na cadeia orgânica. A equação de combustão com 50\% de excesso de ar, valor típico de incineradores atuais de grelhas mecânicas, é mostrada a seguir.

$$
\mathrm{CH}_{1,09} \mathrm{O}_{0,96}+1,19 \mathrm{O}_{2}+4,47 \mathrm{~N}_{2}=>\mathrm{CO}_{2}+0,55 \mathrm{H}_{2} \mathrm{O}+4,47 \mathrm{~N}_{2}+0,40 \mathrm{O}_{2}
$$

Tabela 6.4 - Composição volumétrica na exaustão considerando $50 \%$ de excesso de ar

\begin{tabular}{llr}
\hline fração molar no gás de exaustão \\
\hline O2 & \% do total & $6,18 \%$ \\
CO2 & \%gas seco & $6,75 \%$ \\
& \% do total & $15,60 \%$ \\
\hline Elaboração do autor. & $17,05 \%$ \\
\hline
\end{tabular}




\section{4 - Balanço de Massa e Energia}

Os cálculos realizados até aqui possibilitam a elaboração do balanço de massa da usina. A tabela 6.5 resume os dados do balanço global de massa da usina em estudo.

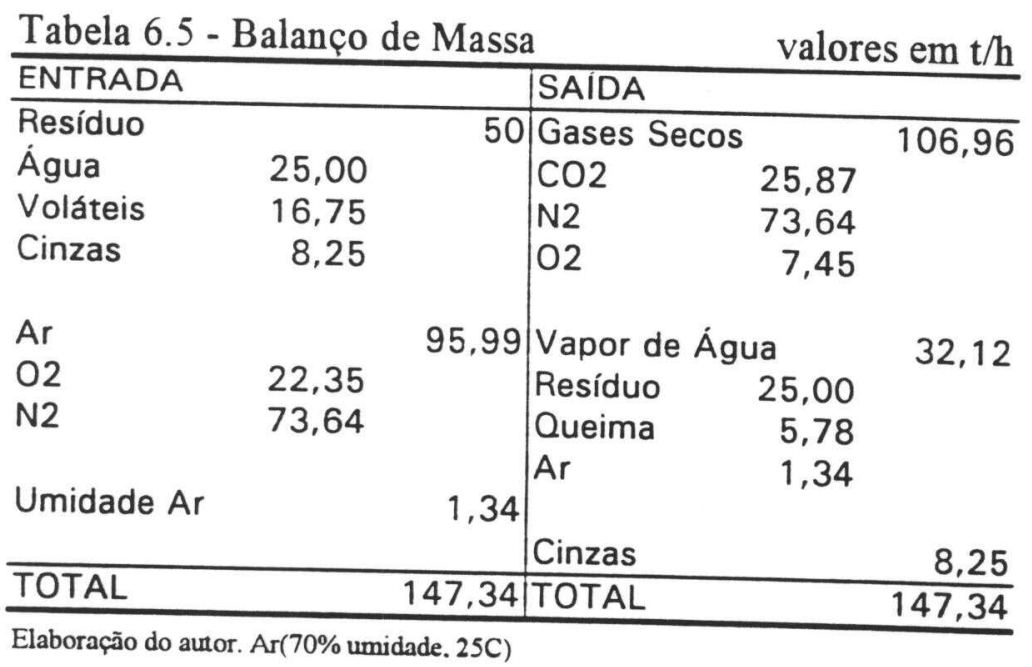

Assim, para cada $\mathrm{kg}$ queimado de material volátil são necessários $1,9 \mathrm{~kg}$ de ar. São gerados $39,5 \mathrm{~kg} / \mathrm{s}$ de gases de exaustão e $8,3 \mathrm{t} / \mathrm{h}$ (198 tpd) de cinzas. A redução de massa a ser aterrada é de $83 \%$, como a densidade das cinzas é superior à do resíduo bruto, a redução de volume de aterro é ainda maior. Estes números são apenas uma primeira aproximação uma vez que a composição química utilizada é uma estimativa e utilizou-se equações simplificadas de combustão. Para a inclusão de mais elementos e espécies químicas, seria necessário o conhecimento de outros parâmetros químicos e físicos não disponiveis e estimativas da temperatura de gaseificação dos resíduos. De posse destes dados, poder-se-ia realizar uma simulação da combustão em software de equilibrio químico (p.ex. Chemkin, do Sandia Lab., EUA). 
Para realizar o balanço de energia é necessário realizar algumas hipóteses. uma vez que uma usina sempre é diferente da outra e determinados parâmetros são derivados de experiências anteriores.

A primeira estimativa é da quantidade de calor aproveitada pela caldeira, que se traduz na eficiência da caldeira. Este valor é específico para cada tecnologia e caracteristica da usina. A tecnologia selecionada para estudo foi um incinerador de grelhas mecânicas com caldeiras de parede de água com passes radiantes e convectivos. Caldeiras atuais são capazes de retirar entre $70 \%$ e $80 \%$ do calor da combustão [KOWLES, 1993]. Pressões de vapor na caldeira da ordem de $60 \mathrm{kgf} / \mathrm{cm}^{2}$ e $413 \mathrm{C}$, já são possíveis com os novos desenvolvimentos das tecnologias de incineração. Usinas nos EUA já operam com esta pressão apresentando disponibilidades acima de 90\% [GIBBS, 1988 \& GIBBS, 1990].

Descontada a energia cedida ao vapor, o restante do calor gerado na combustão é transferido às cinzas, aos gases de exaustão e perdido por radiação e convecção. $\mathrm{Na}$ literatura encontra-se valores da temperatura de saída e calor específico das cinzas. A temperatura das cinzas é limitada pelo seu ponto de início de fusão. Esta temperatura nunca pode ser atingida sob o risco de entupimento e travamento das grelhas. Para o presente estudo, será assumida uma temperatura de saída de $447 \mathrm{C}$ e calor específico de $1,046 \mathrm{~J} / \mathrm{kg} . \mathrm{K}$. As perdas por radiação e convecção são da ordem de $2 \%$ [BRUNNER,1991]. Desta forma pode-se elaborar o balanço simplificado de energia na usina mostrado na tabela 6.6. A energia de vaporização da água do resíduo e resultante da queima já está descontada uma vez que foi utilizado para o cálculo o valor do poder calorífico inferior. A energia contida nos gases de exaustão é ainda aproveitada para préaquecimento do ar de combustão o qual permitirá o aumento da temperatura de reação garantindo uma temperatura de chama superior a $1000 \mathrm{C}$.

Tabela 6.6 - Balanço de Energia $(\mathrm{em} \mathrm{kJ} / \mathrm{h}$ )

\begin{tabular}{lc|lc}
\hline ENTRADA & & SAIDA & \\
\hline Resíduo & 594070 & Vapor & 475256 \\
& & Cinzas & 3646 \\
& & Perdas & 11881 \\
& & Gases & 103286 \\
\hline Total & 594070 & & 594070 \\
\hline
\end{tabular}




\section{5 - Ciclo de Vapor e Geração de Energia}

A energia absorvida pela água da caldeira é utilizada para produção de vapor que é expandido em uma turbina acoplada ao gerador elétrico, transformando então parte da energia térmica em elétrica.

A pressão de extração escolhida foi de $1 \mathrm{kgf} / \mathrm{cm}^{2}(1055 \mathrm{KPa})$, considerada baixa para as usinas de queima de resíduos com pressão na faixa de $60 \mathrm{kgf} / \mathrm{cm}^{2}$ convencionais. Este valor visa uma aumento do rendimento do ciclo. Esta pressão poderia ser ainda alterada para baixo em uma otimização posterior do projeto, com a adição de um ciclo de reaquecimento do vapor o que causaria um aumento da eficiência global do ciclo. Entretanto, os cálculos mostrados são suficientes para uma primeira análise. A vantagem de uma pressão de condensação maior é a possibilidade de uso de condensadores a ar, que, apesar de inicialmente mais caros, possibilitam a indepedência da localização da usina com relação a rios ou represas, e reduzem sensivelmente o consumo de água da usina.

A partir dos dados do lixo entrando na usina e dos parâmetros de projeto realizase cálculo do ciclo de vapor desta usina. Os cálculos encontram-se detalhados no anexo 1. O ciclo de rankine calculado para esta usina é mostrado na figura 6.1. Nesta figura é mostrada ainda uma tabela com os valores calculados no ciclo.

Como mencionado em Penner o rendimento global de conversão de energia em uma usina de incineração é próxima de $20 \%$ (do lixo a eletricidade). Este valor de rendimento tem evoluído com o avanço das tecnologias de incineração. No caso da usina calculada, a capacidade de geração é de $31 \mathrm{MW}$, sobre os quais deve ser descontado o consumo interno. O rendimento global é de $18,9 \%$, valor este muito próximo dos encontrados na literatura. 


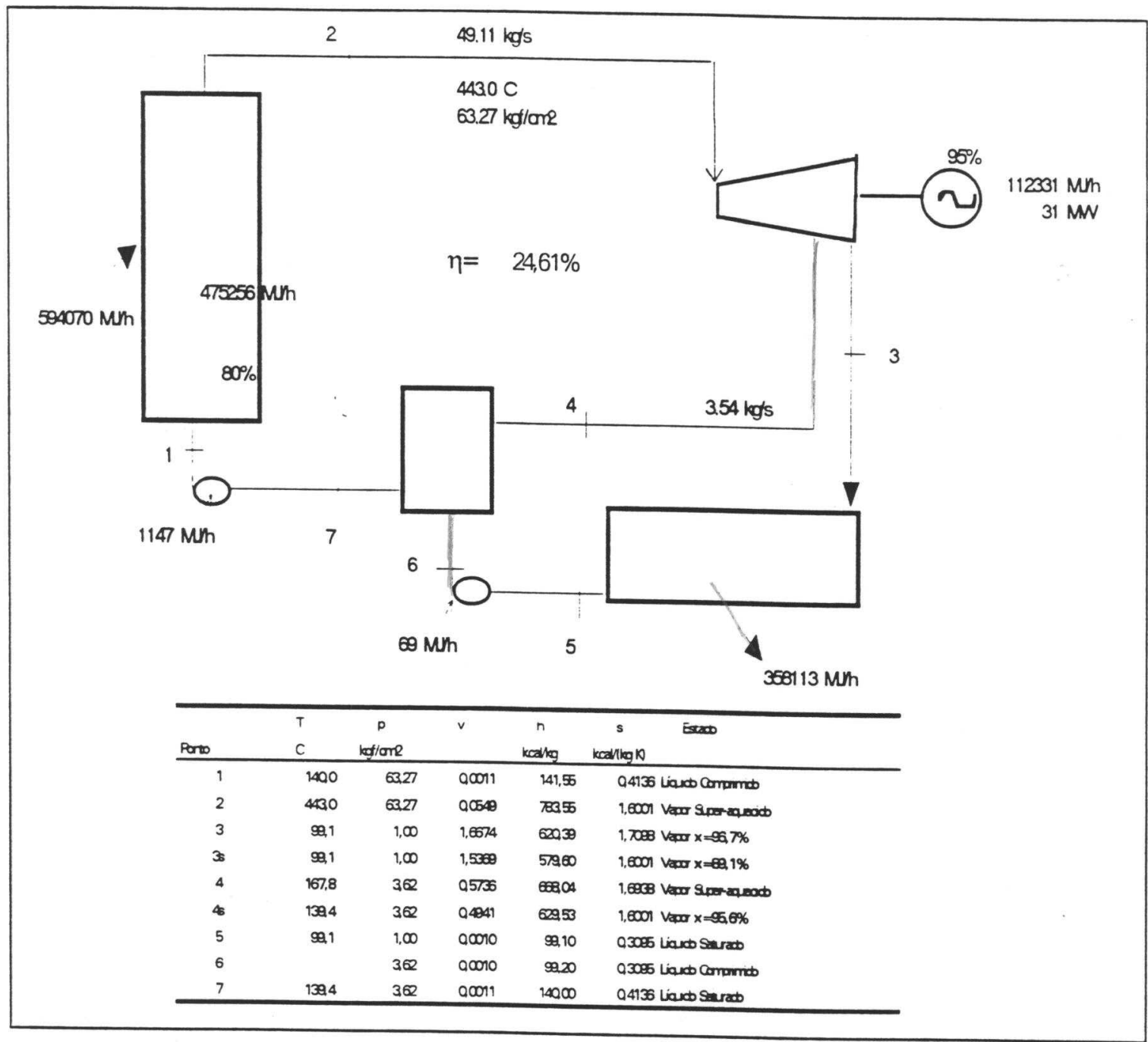

Figura 6.1 - Ciclo de Rankine calculado para a usina do ABCD.

\section{6 - Análise Financeira}

\subsection{1-Custos}

'Estimar os custos de capital reais para projetos de incineradores de larga escala é uma tarefa extremamente dificil. Incineradores são equipamentos complexos, com a maioria das tecnologias proprietárias...' [CHAPPELL, 1991]. O fato de serem as tecnologias proprietárias dificulta o levantamento dos custos de uma nova usina. Para o Brasil os dados são muito escassos já que não existem incineradores de RSU de grande porte implantados no país e as experièncias de licitações para construção são poucas. Desta forma, optou-se por realizar-se uma estimativa a partir de custos de usinas 
similares ("mass-burn", grelhas mecânicas) publicados em artigos ou notas de revistas especializadas.

Esta opção ainda possui a vantagem de diluir as possíveis particularidades de determinado projeto no custo médio a ser estimado. A discrepância encontrada atualmente, principalmente entre valores divulgados aqui no Brasil e aqueles de usinas americanas e européias, poderia ser explicada pela inclusão (exclusão) dos custos de equipamentos sofisticados de controle da poluição. As normas de emissões nos países desenvolvidos está cada vez mais rigorosa, exigindo a adoção de sofisticados, e caros, sistemas de limpeza dos gases. Apesar da norma brasileira ainda ser bastante flexível, um bom critério de projeto seria a seleção de equipamentos que atendam a normas mais rigorosas, evitando-se assim um futuro fechamento da usina para incorporação de novos dispositivos. Desta forma, o valor retirado a partir da análise dos custos disponíveis de usinas no exterior, servem como um sinalizador adequado do custo de uma usina nos padrões modernos.

A figura 6.2 mostra os custos totais do conjunto de usinas para as quais se conseguiu localizar custos de capital. Os valores estão apresentados em dólares de 1993. Realizou-se uma regressão linear sobre os valores entre 900 e 1800 tpd com os seguintes resultados:

$$
\begin{aligned}
& y=241864,9 \cdot x-1,06 \cdot 10^{+8} \\
& r^{2}=0,94 \\
& \sigma_{y}=2,36 \cdot 10^{+7}
\end{aligned}
$$

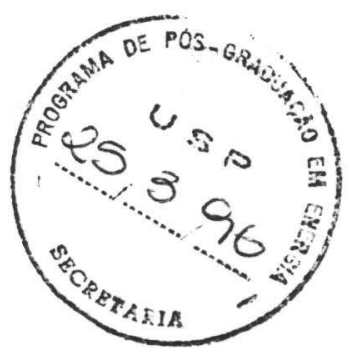

Assim o valor para 1200 tpd obtém-se o valor de US\$ 18424 milhões para o custo de capital da usina.

A figura 2.4 mostra os valores de custo de capital específico (US\$/tpd) em função do tamanho da usina para os mesmos dados da figura 2.1. Neste gráfico pode-se observar a existência de ganhos de escala. Existiriam então três faixas distintas para cálculo do custo específico de uma usina: até 900 tpd, entre 900 e 1800 tpd e acima de 
1800 tpd. Para a faixa entre 900 tpd e 1800 tpd a regressão linear dos pontos resultou na seguinte equação:

$$
\begin{aligned}
& y=0,11402 \cdot x-14,2293 \\
& r^{2}=0,94 \\
& \sigma_{y}=11,58
\end{aligned}
$$

O valor da usina baseada na curva acima é de US\$ 14714 milhões. Adotar-se-á o valor de US\$ 184 milhões para a usina em análise. Este valor permitirá uma análise conservativa dos resultados do empreendimento. Neste valor estão incluídos não só os equipamentos, como também obras civis, engenharia e supervisão e montagem.

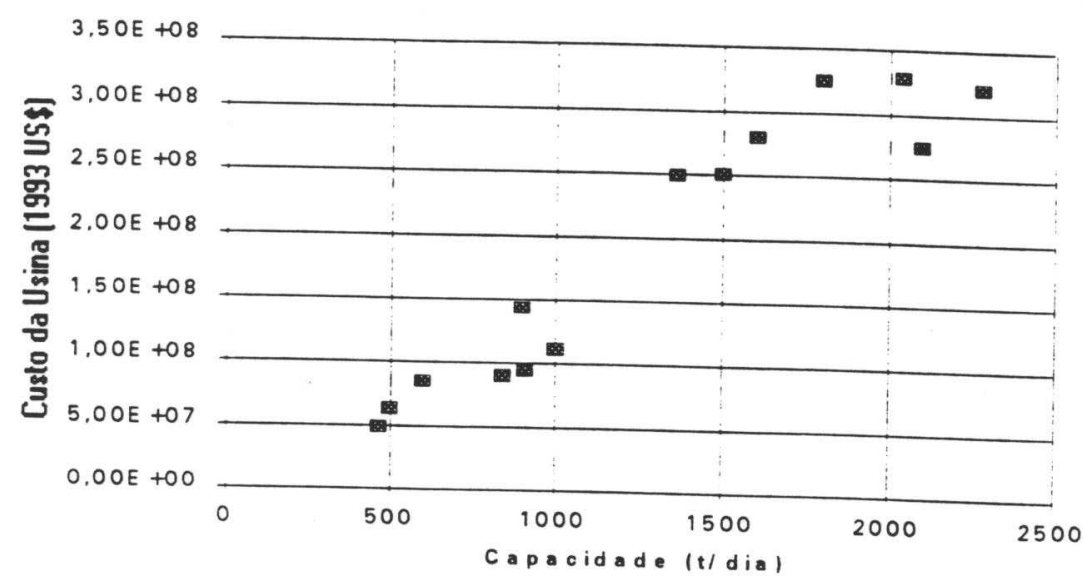

Figura 6.2 - Custos de Capital de Usinas de RSU.

Fonte: Power, diversos números. e outros.

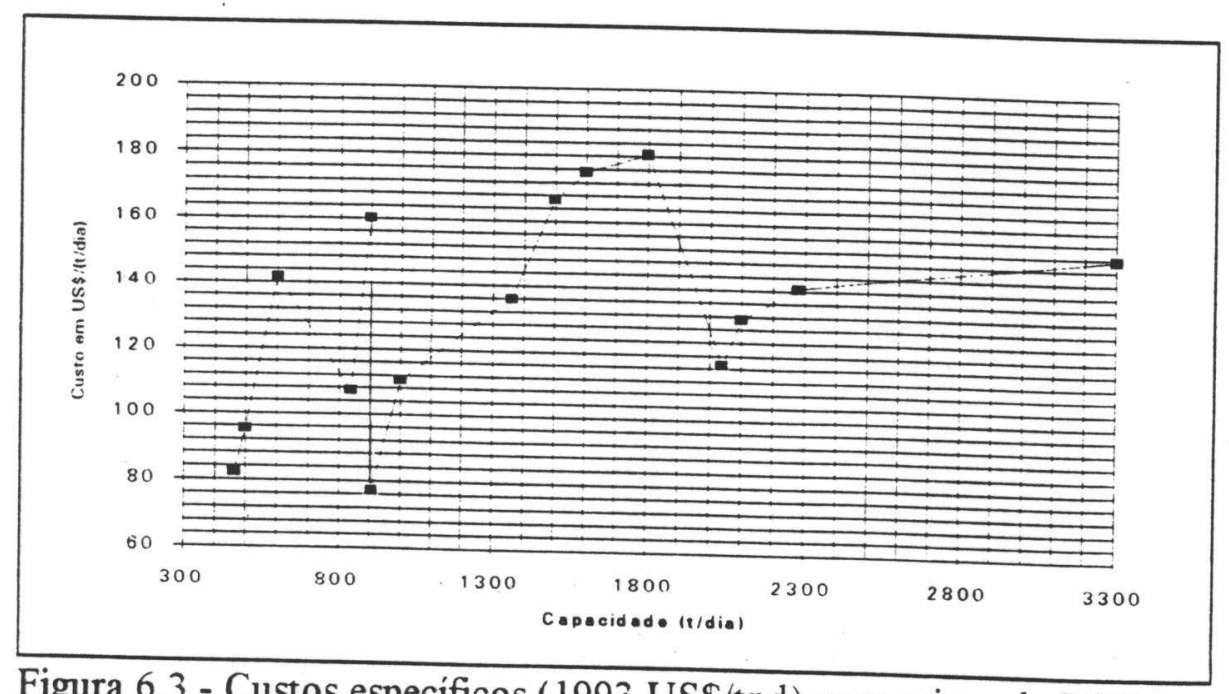

Figura 6.3 - Custos específicos (1993 US\$/tpd) para usinas de RSU. 


\subsection{2 - Projeção Financeira}

Estimado o custo de capital da usina, procede-se a análise da viabilidade financeira do empreendimento. As planilhas completas de análise estão colocadas no Anexo 2. Para realizar uma análise do empreendimento, novos parâmetros devem ser estimados. O custo do terreno escolhido é de US\$ 30,7 milhões. Pode-se estimar que $10 \%$ do custo de capital sejam necessários para contigências do projeto. Desta forma, as necessidades do projeto são apresentadas na tabela 6.7 abaixo.

Tabela 6.7 - Investimentos para usina de incineração de 1200 tpd.

\begin{tabular}{ll}
\hline Componente & Valor \\
\hline Usina $^{1}$ & US\$ 184000000 \\
Terreno $^{2}$ & US\$ 30700000 \\
Contingências $^{3}$ & US\$ 18400000 \\
\hline Total & US\$ 233 100000 \\
\hline 1 - Inclui equipamentos, montagem, obras civis, engenharia e supervisão \\
2 - Área AR 23 (Mauá) fonte: FILSAN, 1992. \\
3 - 10\% do custo da usina.
\end{tabular}

Assume-se ainda:

Custos operacionais

Taxa de desconto

Tempo de Retorno do Capital

Preço de Venda da Energia Elétrica

Período de Construção da Usina

Financiamento
US\$ 1199000 /ano

$12 \%$ ao ano

15 anos

US\$ 39 / MWh

24 meses

$70 \%$ do investimento total

No presente estudo assume-se que parte do investimento é realizado com capital tomado junto ao mercado financeiro. Usualmente, o financiamento cubre somente uma parcela do investimento sendo exigida uma contrapartida de capital próprio. No caso, a divisão é $30 / 70$. ie, $30 \%$ do investimento deve ser realizado com capital próprio. Os $70 \%$ seriam tomados nas condições abaixo mostradas na tabela 6.8 . 
Tabela 6.8 - Condições do financiamento

\begin{tabular}{lrl}
\hline Taxa de juros (nominal) & $10 \%$ ao ano & inclui taxas de deposito, IOF, Inflacao no periodo,etc \\
Carencia & 36 meses & juros e principal (juros durante const. capitalizados) \\
Capitalizacao dos juros & 6 meses & \\
Periodo de amortizacao & 9 anos & SAC - sistema de amortizacao constante \\
& 1 por ano & (parc amort. iguais, juros tx ${ }^{*}$ saldo devedor) \\
Prestacoes & 12 anos & carencia + periodo amortizacao \\
Prazo total do financ. &
\end{tabular}

Assumindo o cronograma de investimentos durante a implantação mostrado na tabela 6.9, elaborou-se a planilha do financiamento especificando o saldo devedor, juros e amortizações. A taxa interna de retorno com base no fluxo de caixa do banco representa o custo efetivo do empréstimo, que neste caso, é de $9,23 \%$ a.a.

Tabela 6.9 - Cronograma de desembolsos durante a implantação

\begin{tabular}{lrrr}
\hline & $1^{\circ}$. Ano & $2^{\circ}$. Ano & \multicolumn{1}{c}{$\begin{array}{c}\text { Total } \\
\text { inversões }\end{array}$} \\
\hline Terreno & 30700000 & & 30700000 \\
Construção Civil & 12245200 & 12245200 & 24490400 \\
Montagem & 10828400 & 10828400 & 21656800 \\
Equipamentos & 55356400 & 55356400 & 110712800 \\
Engenharia/Supervisão/etc & 4351600 & 4351600 & 8703200 \\
Despesas Pré-operacionais 1 & 18418400 & 18418400 & 36836800 \\
\hline \multicolumn{1}{r}{ Total } & 131900000 & 101200000 & 233100000 \\
\hline
\end{tabular}

Assumindo inversões realizadas sempre ao final do periodo s/incluir refinanciamento Obs: Composição baseada em valores encontrados em A. Araújo Eng. Ltda, 1992.

Tabela 6.10 - Planilha do Financiamento (em US\$)

\begin{tabular}{crrrr}
\hline ANOS & $\begin{array}{c}\text { Saldo } \\
\text { Devedor }\end{array}$ & Juros & Amortização & Prestação \\
\hline 1 & 81585000 & & & \\
2 & 171532463 & 8362463 & & 17582077 \\
3 & 171532463 & 17582077 & & \\
\hline 4 & 152473300 & 17582077 & 19059163 & 36641240 \\
5 & 133414138 & 15628513 & 19059163 & 34687676 \\
6 & 114354975 & 13674949 & 19059163 & 32734112 \\
7 & 95295813 & 11721385 & 19059163 & 30780547 \\
8 & 76236650 & 9767821 & 19059163 & 28826983 \\
9 & 57177488 & 7814257 & 19059163 & 26873419 \\
10 & 38118325 & 5860692 & 19059163 & 24919855 \\
11 & 19059163 & 3907128 & 19059163 & 22966291 \\
12 & 9 & 1953564 & 19059163 & 21012727 \\
\hline \multicolumn{6}{c}{ Custo efetivo do empréstimo } \\
\hline \multicolumn{5}{c}{$9.23 \%$} \\
\hline
\end{tabular}


Observa-se que os juros durante a construção remontam a US\$ 8.360 .000 e são capitalizados, entrando assim para o valor a ser recuperado pelo empreendimento. Com este valor pode-se realizar uma estimativa inicial para o custo da tonelada incinerada. Para esta estimativa utiliza-se uma taxa de desconto de $12 \%$, usual em avaliações de projetos desta natureza. O valor encontrado permitirá a elaboração de planilhas de análise da viabilidade financeira do empreendimento que por sua vez permitirão estabelecer uma taxa de incineração que permita um retorno aceitável do investimento.

FRC (12\% a.a., 15 anos $)=0,1468$

Valor do Investimento $\left(\mathrm{I}_{\mathrm{o}}\right)=$ US $\$ 241.462 .463$

Valor anualizado $=$ US $\$ 35.452 .542$ /ano

Custo O\&M $\left(\mathrm{C}_{\mathrm{O} \& \mathrm{M}}\right)=$ US\$ $1.199 .980 /$ ano

Fator de Disponibilidade (FD) $=88 \%$

Lixo incinerado $(1200$ tpd $* 365 \mathrm{~d} * \mathrm{FD})=384.990 \mathrm{t} /$ ano

$$
C=\frac{I_{o} \cdot F R C+C_{\text {O\&M }}}{1200 t p d \cdot F D}=95,20 U S \$ / t
$$

Considerando a potência de $31,14 \mathrm{MW}_{\mathrm{e}}$ da usina, sua disponibilidade, um consumo próprio de $3 \mathrm{MW}$ (A.Araújo, 1991) e o fator de disponibilidade equivalente à disponibilidade usina pode-se estimar uma geração de $0,56 \mathrm{MWh} / \mathrm{t}$ de resíduo incinerado.

Uma questão a se considerar é o preço de venda de energia elétrica. Como as usinas de incineração devem funcionar o maior tempo possível para dar fim aos resíduos, sua operação corresponderia à de uma usina na base do sistema. Isto implica na necessidade de um contrato de venda de energia firme e a longo prazo. A energia poderia ser comprada pela companhia concessionária ou diretamente por algum consumidor interessado em adqüirir energia a longo prazo. Na Europa e EUA, diversos esquemas têm sido testados, inclusive com venda também de vapor. Nos EUA. o Public Utility 
Regulatory Policies Act de 1978 estabeleceu que as empresas concessionárias deveriam comprar a energia gerada por usinas qualificadas como as de incineração de resíduos. Entretanto, encontrar um contrato satisfatório de venda de energia é considerado um dos passos mais dificeis na implementação de uma usina de incineração de resíduos. Um dos esquemas de preço, com sucesso mencionado, é o sistema de cone que fixa o piso e máximo para o preço de eletricidade baseado na evolução dos custos evitados da concessionária. [AMERICAN REF-FUEL, 1986].

Para o presente caso, supõe-se que este acordo seja realizado de forma que toda a energia gerada na usina seja vendida e o preço mínimo seja US\$ 39 /MWh, correspondente ao custo marginal de geração e transmissão do sistema sul-sudeste. Este valor pode ser considerado um patamar inferior uma vez que a usina estará localizada em um grande centro de carga que é a região do $\mathrm{ABCD}$, o que a torna atrativa do ponto de vista de geração. Desta forma, pode-se calcular a taxa que deveria ser cobrada pela incineração dos resíduos. Os valores para taxas de desconto de $12 \%$ e $15 \%$ e três valores de preço de eletricidade estão mostrados na tabela 6.11.

Tabela 6.11 - Taxa de Incineração (USS/t) em função da taxa de desconto e preço de venda de eletricidade.

\begin{tabular}{c|ccc}
\hline $\begin{array}{c}\text { Taxa de } \\
\text { Desconto }\end{array}$ & \multicolumn{3}{|c}{ Preço de Venda de Eletricidade } \\
& 50 & 39 & 60 \\
\hline $12 \%$ & 67.03 & 73.23 & 61.40 \\
$15 \%$ & 82.21 & 88.40 & 76.57 \\
\hline
\end{tabular}

Assumiu-se, para os cálculos financeiros restantes, uma taxa desconto de $12 \% \mathrm{e}$ um preço de eletricidade de US\$39/MWh. Para se elaborar as planilhas de projeção de resultados, quadro de fontes e usos de recursos e a projeção do fluxo de caixa assumiuse ainda um critério de depreciação conforme permite a lei brasileira. Estes critérios estão resumidos na tabela 6.12 a seguir. 
Tabela 6.12 - Critérios de depreciação dos investimentos

\begin{tabular}{lrrl}
\hline Ativo & Tempo & \multicolumn{1}{c}{ Taxa } & Tipo \\
\hline Construção Civil & 12.5 anos & $8 \%$ a cada ano & acelerado \\
Equipamentos & 5 anos & $20 \%$ a cada ano & acelerado \\
Pre-operacionais & 5 anos & $20 \%$ & \\
\hline
\end{tabular}

Depreciação linear; Critério: acelerado por 2 em função da operação em 3 turnos As despesas pré-operacionais incluem juros durante construção

A planilha de Projeções de Resultado (tabela 6.13) tem maior significado em termos contábeis, uma vez que mostra o lucro para fins fiscais, sendo a depreciação incluída como despesas. As amortizações do financiamento não entram como despesa evitando dupla contagem, já que a depreciação corresponde a uma "amortização" do investimento. É interessante entretanto notar a importância assumida pela depreciação e do pagamento do financiamento. O peso da carga tributária também pode ser avaliadada comparando-se os valores de lucro antes e depois dos impostos.

No quadro de Fontes e Usos de Recursos a depreciação entra como fonte de recursos. Este quadro é bastante importante na construção do balanço anual da empresa, permitindo análise da variação do ativo e do passivo. Finalmente a planilha de Projeção de Fluxo de Caixa ilustra as entradas e saidas reais de unidades monetárias da empresa. Aqui a depreciação não deve ser considerada por ser apenas um artificio contábil que permite acelerar a recuperação do capital investido através de descontos nos impostos. A diferença entre as entradas e saidas indicam recursos reais aportados ou colocados à disposição dos acionistas. Este saldo é utilizado para cálculo da taxa interna de retorno do empreendimento. 
Tabela 6.13 - Projeções de Resultado

\begin{tabular}{|c|c|c|c|c|c|c|c|c|c|c|c|c|c|c|c|c|c|c|c|c|}
\hline 1. & 2 & 4 & 5 & 6 & 7 & 8 & $\theta$ & 10 & 11 & 12 & 13 & 14 & 15 & 16 & 17 & 18 & 19 & 20 & 21 & $\frac{22}{1525}$ \\
\hline $\begin{array}{l}\text { EENDAS (A) } \\
\text { Enorgia Elentica } \\
\text { Incineracaso }\end{array}$ & $\begin{array}{r}36652522 \\
845969 \\
28192757\end{array}$ & $\begin{array}{r}36652522 \\
845966 \\
28192757\end{array}$ & $\begin{array}{r}36652522 \\
84586766 \\
28192757\end{array}$ & $\begin{array}{r}36652522 \\
845966 \\
28192757\end{array}$ & $\begin{array}{r}36652522 \\
8459766 \\
28192757\end{array}$ & $\begin{array}{l}36652522 \\
8459766 \\
28192757\end{array}$ & $\begin{aligned} 366525222 \\
8459766 \\
28192757\end{aligned}$ & 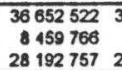 & $\begin{array}{l}366525223 \\
8445768 \\
281927572\end{array}$ & $\begin{array}{r}366525223 \\
8459768 \\
281927572\end{array}$ & $\begin{array}{r}36652522 \\
845968 \\
28192757\end{array}$ & $\begin{array}{r}36652522 \\
845968 \\
281927572 \\
28\end{array}$ & $\begin{array}{l}36852522 \\
8459696 \\
28192757\end{array}$ & $\begin{aligned} 36652522 \\
8459766 \\
28192757\end{aligned}$ & $\begin{array}{r}36652522 \\
845966 \\
28192757\end{array}$ & $\begin{array}{r}36652522 \\
8456766 \\
28192757 \\
\end{array}$ & $\begin{array}{r}36652522 \\
845968 \\
28192757 \\
281927\end{array}$ & $\begin{array}{r}36652522 \\
845966 \\
281927572 \\
28\end{array}$ & 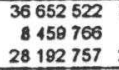 & $\begin{array}{r}366525252 \\
8459768 \\
28192757 \\
28197\end{array}$ \\
\hline 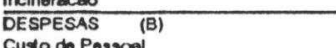 & 57995702 & 57995702 & 56042138 & $\frac{104088574}{54079}$ & 52135009 & $\frac{2027033}{12927033}$ & 1097369 & 0010904 & 7066340 & 5112776 & 3159212 & 3159212 & 2179596 & 1190980 & 1169980 & 1199980 & 1198980 & 1199980 & 1199880 & $\begin{array}{r}1109080 \\
430000\end{array}$ \\
\hline $\begin{array}{l}\text { Custo do Possoal } \\
\text { Cuxo do O\&M }\end{array}$ & $\begin{array}{l}430000 \\
769880\end{array}$ & $\begin{array}{l}430000 \\
789980\end{array}$ & $\begin{array}{l}430000 \\
769980\end{array}$ & $\begin{array}{l}430000 \\
769980\end{array}$ & $\begin{array}{l}430000 \\
769980\end{array}$ & $\begin{array}{l}430000 \\
769980\end{array}$ & $\begin{array}{l}430000 \\
769980\end{array}$ & $\begin{array}{l}430000 \\
769980\end{array}$ & $\begin{array}{l}430000 \\
769890\end{array}$ & $\begin{array}{l}430000 \\
769080\end{array}$ & $\begin{array}{l}430000 \\
769980\end{array}$ & $\begin{array}{l}430000 \\
789980\end{array}$ & $\begin{array}{l}430000 \\
769880\end{array}$ & $\begin{array}{l}430000 \\
769980\end{array}$ & $\begin{array}{l}430000 \\
769980\end{array}$ & $\begin{array}{l}130000 \\
769980\end{array}$ & $\begin{array}{l}430000 \\
769980\end{array}$ & $\begin{array}{l}4300000 \\
769980\end{array}$ & 769880 & 769880 \\
\hline 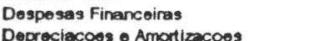 & 17582077 & 17582077 & 15628513 & 13674949 & 11721385 & 0787821 & 7814257 & 5860692 & 3007128 & 1953584 & & & & & & & & & & \\
\hline 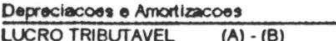 & $\frac{39213645}{21313}$ & 39213645 & 39213645 & 39213645 & 39213645 & $\frac{1959232}{2375250}$ & $\frac{1959232}{2587054}$ & $\frac{1.959232}{278325102}$ & $\frac{1959232}{19598}$ & $\frac{1958232}{3152789}$ & $\frac{1959232}{230330}$ & $\frac{1959232}{33033103}$ & $\frac{979616}{34420263}$ & & & & & & & \\
\hline $\begin{array}{l}\text { LUCRO TRIBUTAVEL } \\
\text { Cortribuicao Social }\end{array}$ & 343179 & 21343178 & -19389615 & -17436051 & 154824872 & $\begin{array}{r}23725490 \\
2158883 \\
\end{array}$ & $\begin{array}{r}258790542 \\
2334459\end{array}$ & 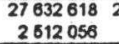 & $\begin{array}{c}295861823 \\
2689653\end{array}$ & $\begin{aligned} & 315397483 \\
& 2887250\end{aligned}$ & $\begin{array}{r}33493310 \\
3044848\end{array}$ & $\begin{array}{r}\begin{array}{r}334933103 \\
3044848\end{array} \\
3\end{array}$ & $\begin{array}{r}34472926 \\
3133902 \\
\end{array}$ & $\begin{array}{r}35452542 \\
3222958 \\
\end{array}$ & $\begin{array}{r}354525423 \\
3222958 \\
\end{array}$ & 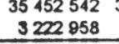 & $\begin{array}{r}r 5452542 \\
3222968 \\
\end{array}$ & $\begin{array}{r}35452542 \\
3222958 \\
\end{array}$ & $\begin{array}{r}35452542 \\
3222958 \\
\end{array}$ & $\begin{array}{r}\begin{array}{r}35452252 \\
3222958 \\
\end{array} \\
\end{array}$ \\
\hline LUCRO APOS CONTRIBU CAO SOCIAL & 21343179 & 21343719 & 19389615 & 17436051 & 15482487 & 1568627 & 33445942 & 251205622 & 268965292 & 286724973 & 30448464 & 304484643 & 313390243 & 32229584 & 322295843 & 32229584 & 32229584 & 32229584 & 32229584 & 32229584 \\
\hline $\begin{array}{l}\text { imposto do Rencta } \\
\text { Adcional do Imposto do Rench }\end{array}$ & & & & & & 5302 & 583690 & & 6724132 & 7168124 & 7612116 & 7612118 & 7834756 & 8057396 & 8057306 & 8057326 & 8057396 & 8057396 & 8057396 & 805 \\
\hline o do Rench & & & & & & 2140016 & 2317613 & 2495210 & 2672807 & 850403 & 3028000 & 3028000 & 3117058 & 3206112 & 3206112 & 3206112 & 3206112 & 3206112 & 3206112 & 3206112 \\
\hline LUCRO LIOUIDO & 343179 & 343178 & 389615 & 136051 & 482487 & 14036454 & 51808331 & 445212 & 7498500 & 3969 & 8008348 & 808348 & 287212 & 8968078 & 2968078 & 0066076 & 20866076 & 20966078 & 20966076 & 20866076 \\
\hline
\end{tabular}

Tabela 6.14 - Quadro de Fontes e Usos de Recursos

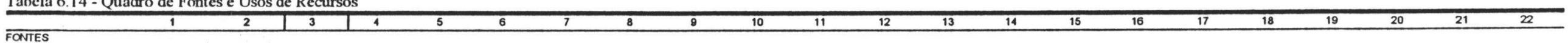

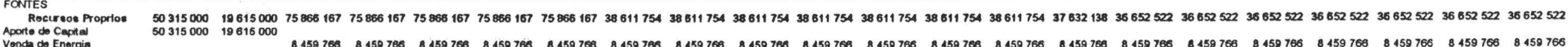

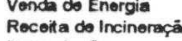

Deprecieçäbo Empristimos

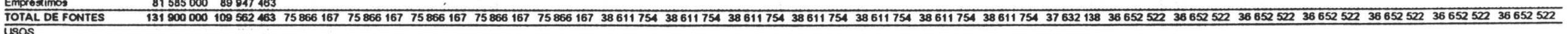

UAllvo Flxo $\quad 131900000109562463$

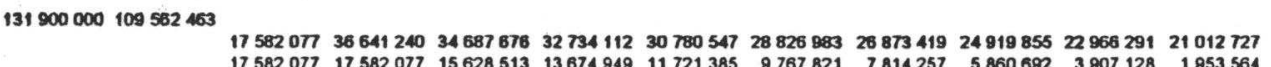

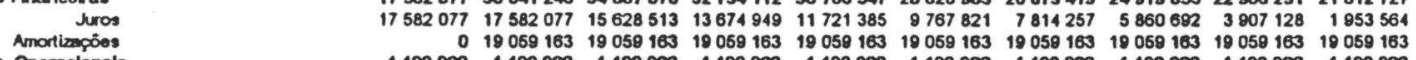

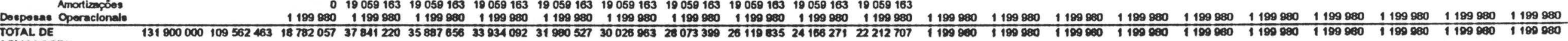
APLLCACOES

MNUL THT(DEFICIT)

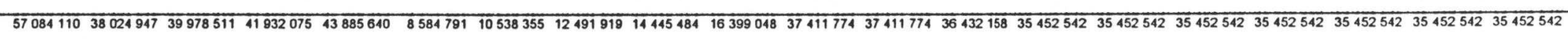

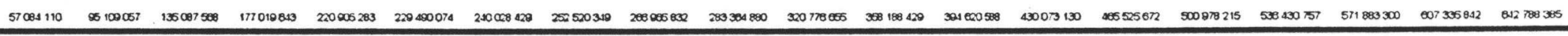

Tabela 6.15 - Planilla ủe Projeção do Fluyo de Caixa

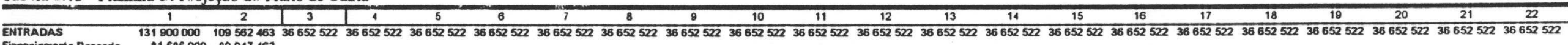

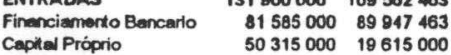

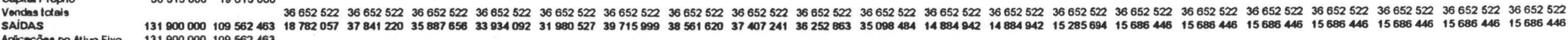

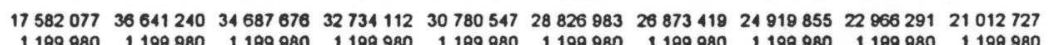

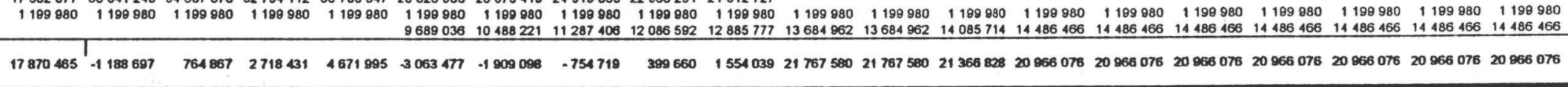
Acionista 
Os quadros acima permitem então o cálculo de figuras de mérito do investimento. A taxa interna de retorno do investimento com as hipóteses fornecidas é de 0,57\%a.a. Esta taxa indicaria uma não atratividade do investimento uma vez que esta taxa é inferior às taxas de aplicação do dinheiro no mercado financeiro e às taxas de retorno usuais do setor produtivo (8-20\% KRAUSE,1994). Como esta taxa é inferior à do capital financiado, o valor presente líquido do empreendimento é negativo (- US\$ 157,5 milhões). Este valor deve ser confrontado com os valores obtidos na análise dos investimentos alternativos. Outra figura de mérito calculada é a taxa interna de retorno do investimento modificada. Esta taxa reflete a taxa de retorno do investimento considerando que as retiradas obtidas no fluxo de caixa podem ser aplicadas em investimento alternativo com taxa de retorno distinta daquela do empreendimento. Esta aplicação se daria durante a vida do empreendimento. Adotando uma taxa de $3 \%$, ainda inferior a de investimentos produtivos, o retorno do investimento passa a ser de $2,4 \%$.

\subsection{3 - Análise de Sensibilidade}

De forma a verificar os parâmetros de maior relevância e certificar a validade dos resultados obtidos com variações das diversas variáveis do problema, realiza-se uma análise de sensibilidade do investimento.

A primeira questão está relacionada com a variação da taxa de incineração quando varia a taxa de desconto. Elaborou-se assim o gráfico mostrado na figura 6.4. Esta figura mostra o crescimento da taxa de incineração com o aumento da taxa de desconto e com a redução do preço da eletricidade vendida. Para uma venda de eletricidade a US\$50, por exemplo, a taxa de incineração varia entre US\$52/t e US\$103/t para uma variação da taxa de desconto entre $9 \%$ a $19 \%$. Para efeito de comparação, no capítulo 3 foi mostrado que o custo médio de destinação na região é de US\$14,50. 


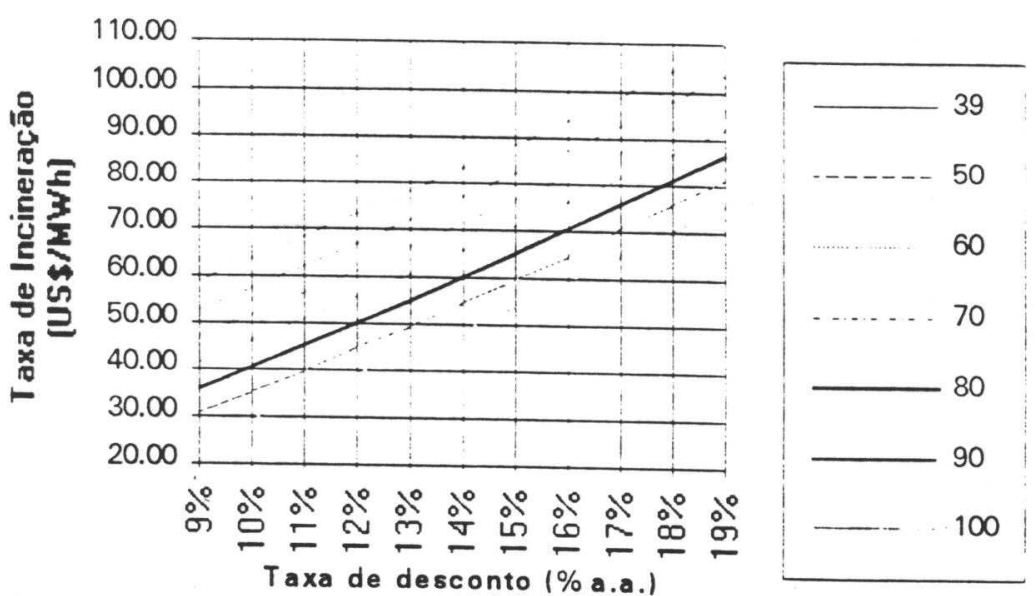

Figura 6.4 - Taxa de incineração em função da taxa de desconto e preço de venda de eletricidade

Como foi mostrado acima, a taxa de desconto, tem um impacto negativo sobre a taxa de incineração (incremento da taxa) a ser pago pelas municipalidades para incinerar os seus resíduos. Dada a incerteza com relação ao valor do custo de capital da usina, realizou-se uma análise da variação, mostrada na figura 6.5 , da taxa de incineração com relação a este parâmetro e taxa de desconto. Outros dois parâmetros importantes são o poder calorífico médio do resíduo e o rendimento global da usina. A sensibilidade com relação a estes parâmetros está ilustrada na figura 6.6.

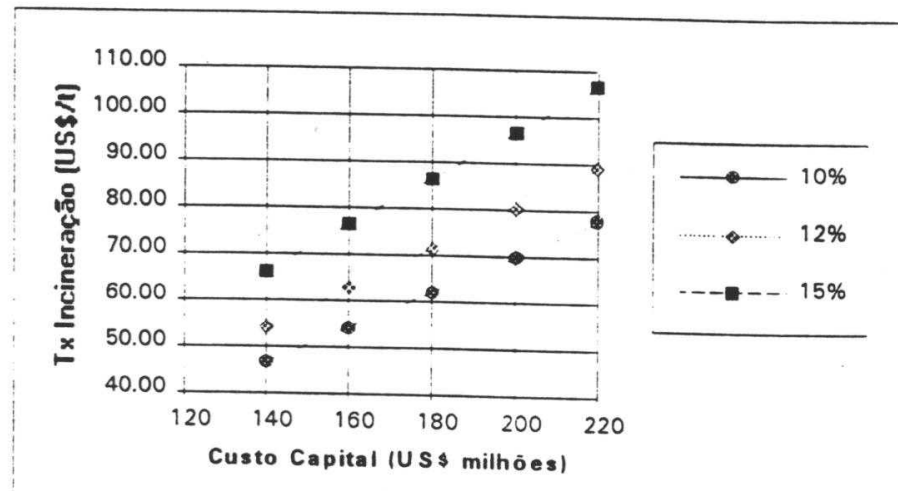

Figura 6.5 - Taxa de incineração em função do custo de capital da usina e taxa de desconto 


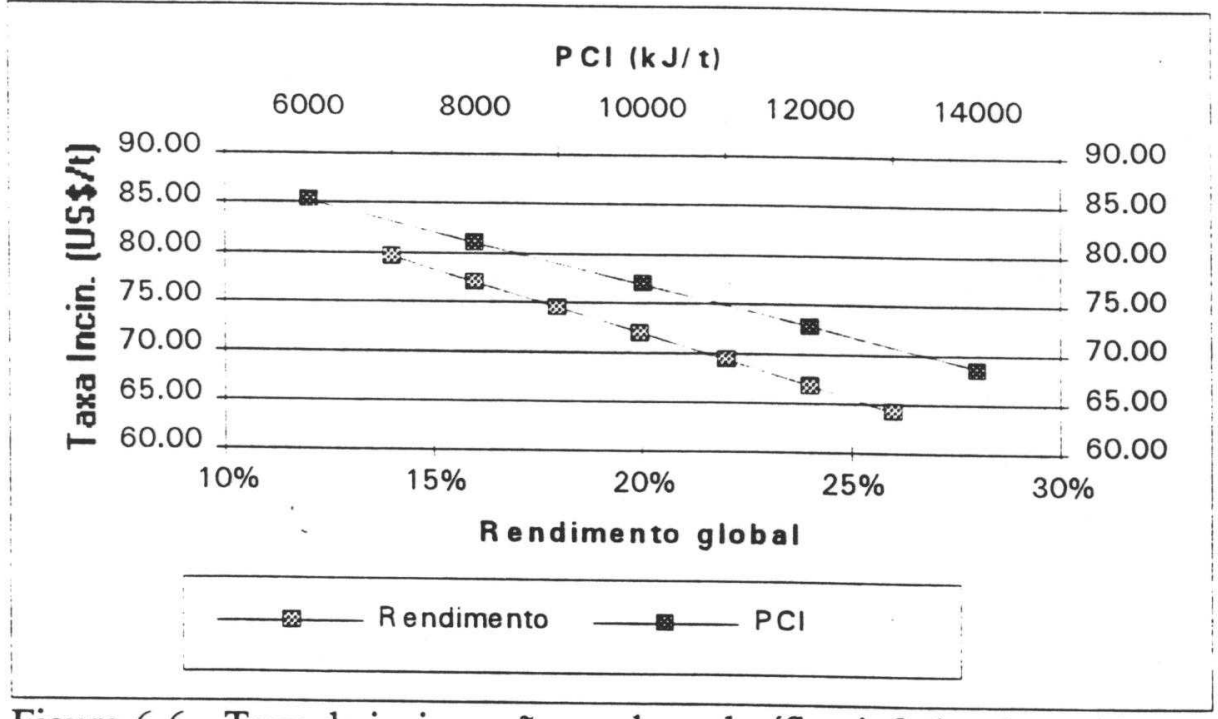

Figura 6.6 - Taxa de incineração, poder calorífico inferior do resíduo e rendimento da usina.

Uma análise interessante é determinar quais dos parâmetros apresentados tem maior influência sobre o valor da taxa de incineração, para que se possa avaliar os resultados de esforços de otimização. Na figura 6.7 a seguir, percebe-se que o custo de capital e taxa de desconto são de importância singular no caso estudado. A taxa de desconto é uma taxa arbitrária determinada segundo o interesse do investidor. A discussão sobre este parâmetro é realizada no item seguinte quando trata-se da análise econômica e social. Já o custo de capital é função do fornecedor e, principalmente, da tecnologia empregada. Ressalta-se aqui a importância do dimensionamento correto e da escolha de tecnologias, ações também influentes sobre o rendimento da usina.

A análise apresentada acima é importante para as municipalidades as quais seriam responsáveis pelo pagamento da taxa de incineração e, por conseqüência para os munícipes que serão influenciados com o aumento em seus impostos municipais. Como já mencionado, os custos atuais de destinação final estão na faixa de US\$15 e os impostos cobrados não chegam a cobrir todas as despesas com a coleta e tratamento de resíduos. Com a adoção da incineração os impostos terão que ser aumentados a fim de compensar os novos custos.

Entretanto, para o empreendedor e operador da usina (mesmo que sejam os próprios municípios) é importante analisar a viabilidade financeira do empreendimento. 
As figuras de 6.8 a 6.10 mostram a variação das principais figuras de mérito. É importante ressaltar o impacto da diminuição da parcela financiada sobre a taxa interna de retorno. Diminuindo-se a quantia financiada, a TIR do empreendimento aumenta. Isto se deve ao fato de que o financiamento exige um retorno em tempo menor, penalizando os resultados do empreendimento. Entende-se como TIR sobre o capital próprio a TIR calculada considerando somente os investimentos de capital próprio, mantendo-se o fluxo de caixa restante. Observa-se que a TIR calculada para o capital próprio está sempre acima de $8 \%$ mesmo para taxas nominais de juros do financiamento de $12 \%$. Este valor converge para aproximadamente $9 \%$.

Considerando que as taxas de incineração utilizadas conduziram a uma baixa atratividade do investimento, realizou-se uma análise do valor desta taxa para valores fixos de retomo do investimento. Esta análise, ilustrada na figura 6.11, mostra que taxas de incineração próximas de US\$100 por tonelada de resíduo incinerado produziriam um retorno do investimento similar aos de outras atividades do setor produtivo. Mesmo taxas de retorno baixas como $2 \%$ conduzem a taxas de incineração próximas a US $\$ 90 / t$, bastante superiores às taxas de destinação e tratamento atualmente pagas pelos municípios.

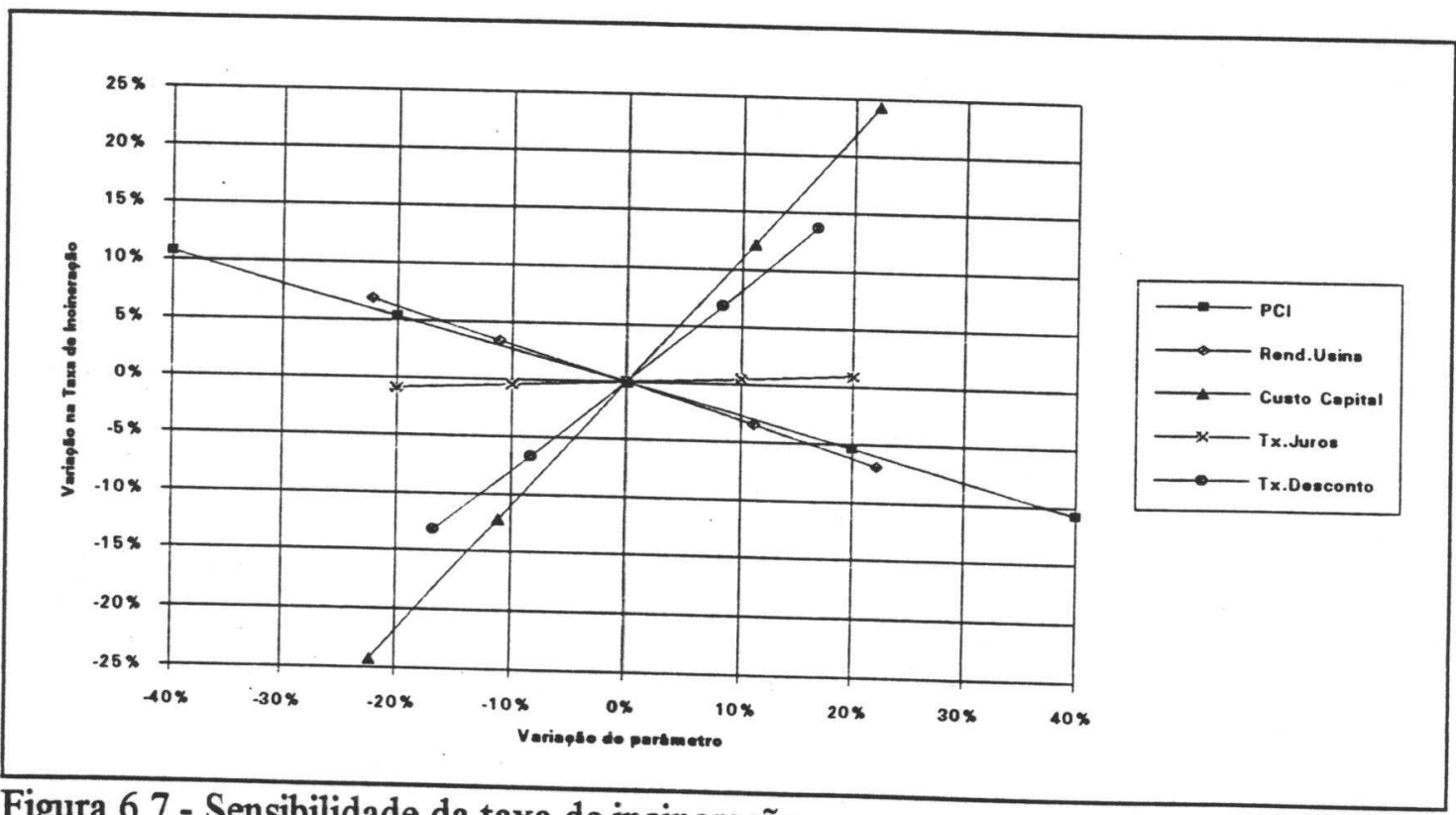

Figura 6.7 - Sensibilidade da taxa de incineração 

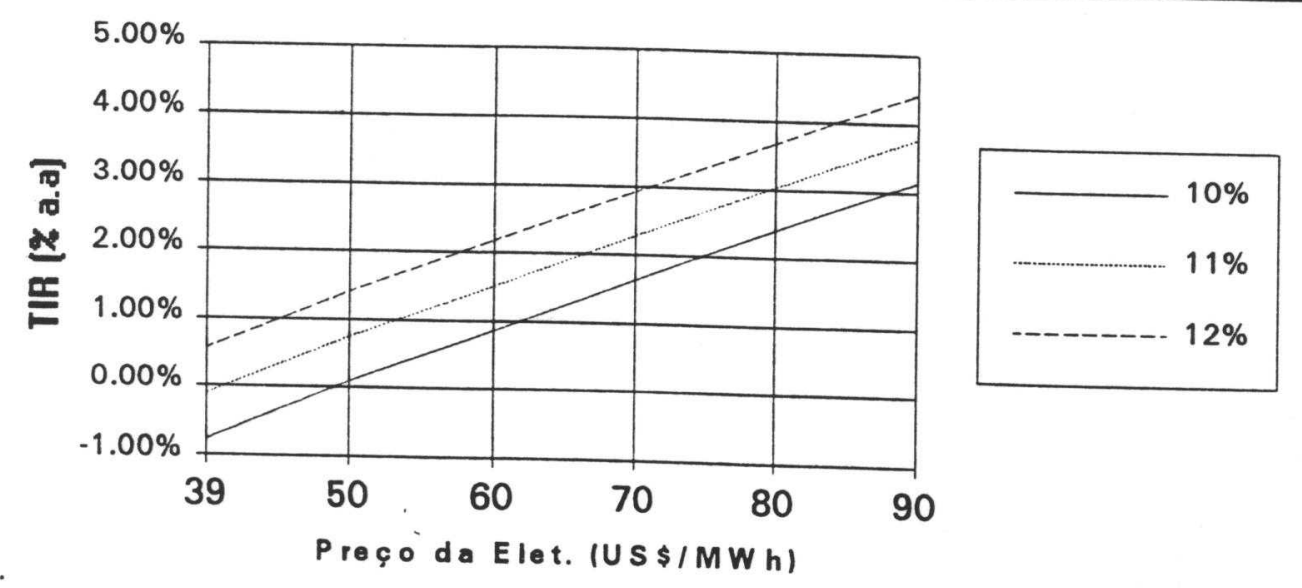

Figura 6.8 - Taxa interna de retorno como função do preço da eletricidade e tx. de desconto.

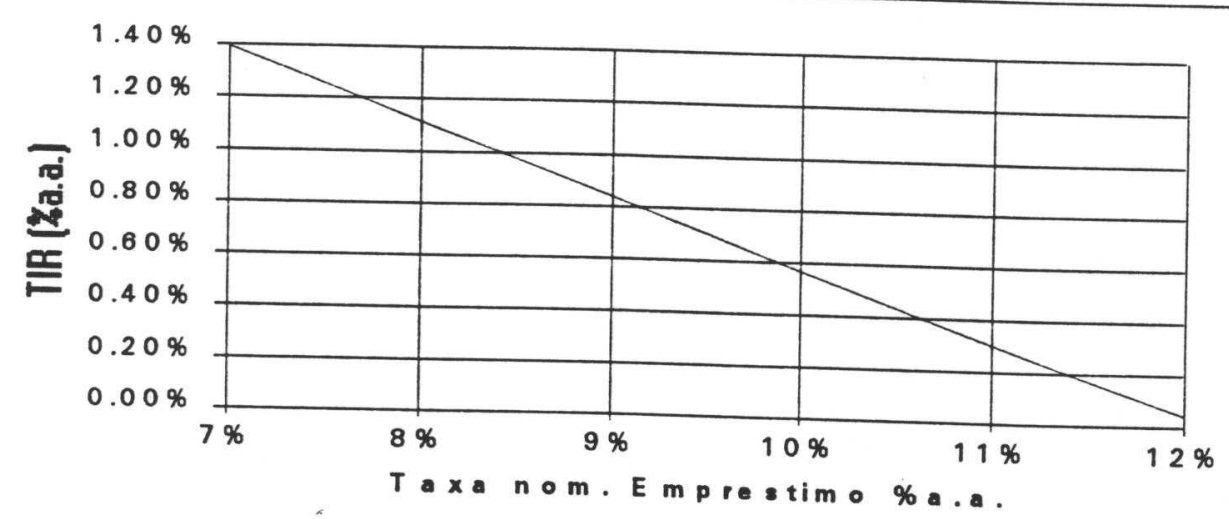

Figura 6.9 - Taxa interna de retorno vs. taxa nominal do financiamento

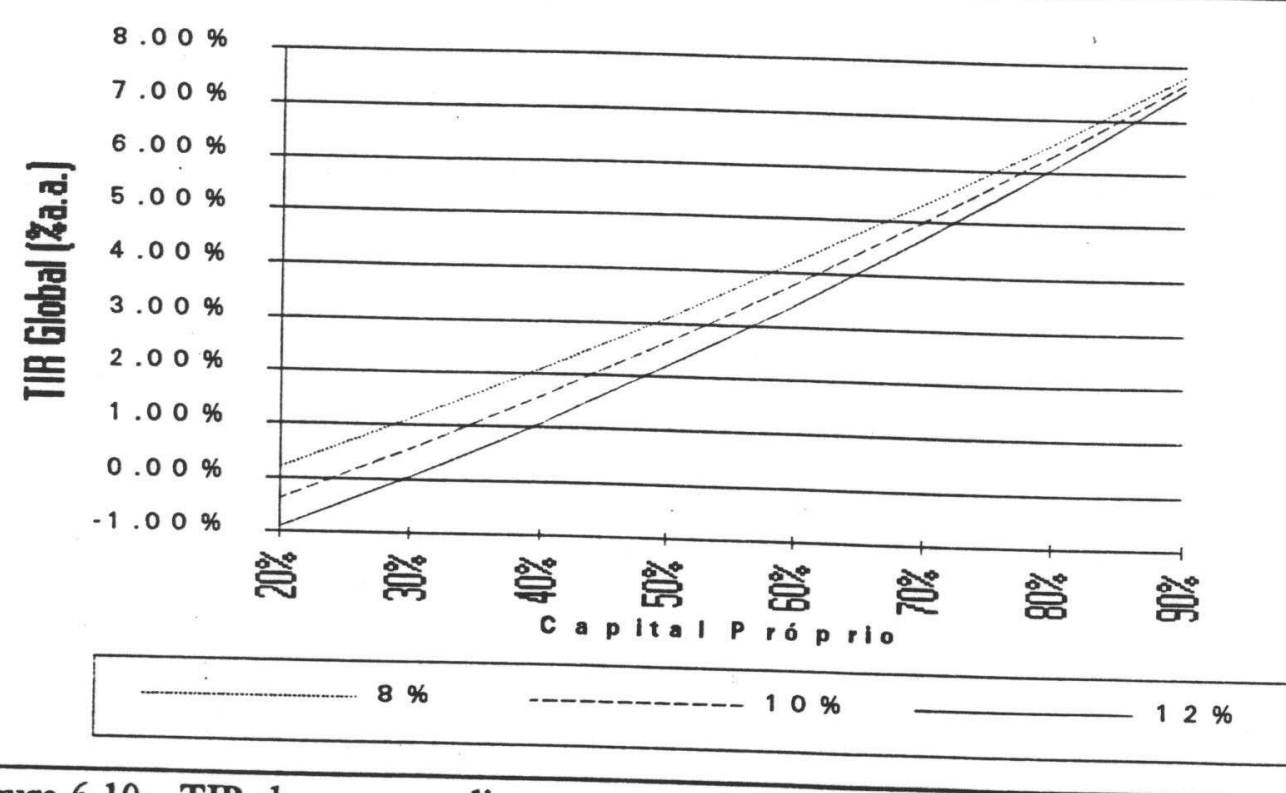

Figura 6.10 - TIR do empreendimento vs. composição do investimento e tx. nominal do financiamento 


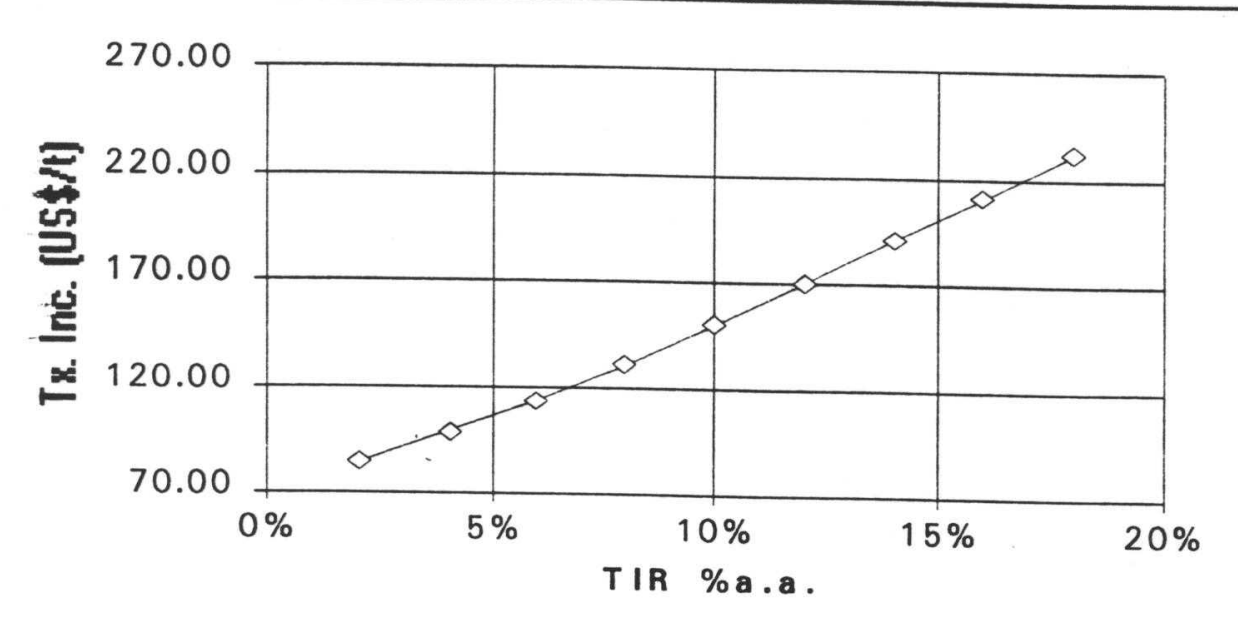

Figura 6.11 - Taxa de Incineração em função do Retorno do Investimento obs: considerando venda de energia elétrica a US $\$ 39 / \mathrm{MWh}$ e geração de $0,56 \mathrm{MWh} / \mathrm{t}$.

\subsection{Análise Econômica}

A análise realizada no item anterior baseou-se nos preços e taxas de mercado com o objetivo final de se obter o fluxo de caixa monetário do empreendimento. Este tipo de análise se constitui em uma análise privada do projeto é chamada de análise financeira. Entretanto, um projeto não pode ser reduzido somente a seus impactos financeiros ao investidor. Associados à criação, implantação, operação e desativação de todo projeto existem diversas externalidades ambientais e sociais. Neste aspecto, a viabilidade de um projeto deve ser considerada após uma avaliação econômica que é aquela na qual se realiza a contabilização de todos os custos do projeto para a economia do país (ou região) e de todos os benefícios derivados do projeto para toda a comunidade, sejam eles captados ou não pelo ente investidor. Este caráter amplo da avaliação econômica a torna uma matéria de dificil aplicação, já que os custos e beneficios estão distruibuídos sobre todo o sistema sócio-econômico. Realiza-se aqui um esboço qualitativo de uma análise econômica, por falta de dados sobre as alternativas ao projeto, preços sombra, etc e também por razões práticas uma vez que o tema é por demais extenso para um tratamento rigoroso em um item de dissertação. 
Através da análise financeira realizada verificou-se a pouca atratividade do projeto que possui valor presente líquido negativo. A taxa interna de retorno estimada para o projeto mostrou-se menor do que qualquer taxa obtida no setor produtivo nacional se praticadas taxas de incineração calculadas a partir de cálculos simplificados utilizando-se taxas de desconto usuais. Para retornos aceitáveis do investimento, as taxas de incineração são quase dez vezes superiores às atualmente pagas pelos municípios para tratamento e destinação final de seus resíduos. Adotando-se então somente o critério financeiro. este projeto deveria ser abandonado. Mas, como lembra Bouille [BOUILLE, 1985], as decisões baseadas na avaliação micro-econômica ou financeira só poderão ser consideradas corretas se os preços de mercado utilizados refletirem todos os custos e beneficios do investimento e ainda os representarem adequadamente para todo 0 conjunto da economia. Estas condições ocorrem somente se cumpridas certas situações hipotéticas. De forma a compensar as distorções nos preços introduzidas por imperfeiçōes do mercado, foi elaborado o conceito de preços sombra para a incorporação dos custos externos e indiretos (sociais e ambientais) na análise econômica. O Banco Mundial sugere a utilização desta metodologia e ainda distingüe entre preços sombra de eficiência, os quais visam a racionalidade econômica apoiada nos princípios da escassez, e os preços sombra sociais que evoluem dos primeiros e considera os efeitos distributivos do projeto (entre classes sociais e gerações).

A discrepância apresentada entre os valores de tratamento de resíduos atualmente assumidos e praticados e os estimados para a incineração é grande e poderia sugerir a inviabilidade econômica do projeto. Entretanto, o mercado sofre atualmente de distorções. sub-avaliando as terras empregadas para os aterros e não incorporando as externalidades associadas a esta prática. Como lembrado por Hickeman e Reimers [HICKMAN. 1994], à medida em que os aterros vão sendo fechados, a oferta de nova capacidade de destinação ou tratamento vai ficando ameaçada pela dificuldade de implantação de qualquer dispositivo de gerenciamento de RSU (aterros, usinas de reciclagem. compostagem, incineração). Esta dificuldade surge do aumento das pressões 
ambientalistas e populares. O resultado deste processo é o aumento progressivo dos custos da nova capacidade, uma vez que a adição de uma nova capacidade é adiada ao extremo, novos dispositivos acabam se localizando muito distantes, ou sistemas muito caros de reciclagem são implementados.

Apesar dos custos crescentes de tratamento e deposição dos residuos, os dirigentes muncipais têm dificuldade de repassar estes custos adicionais como aumento de impostos, resultando, além da criação de um déficit na área de saneamento, na percepção de muitos usuários de um serviço gratuito ou subsidiado. Apenas como exemplo, pode-se citar o caso dos EUA onde os custos de aterro no final da década de 70 estavam na faixa de 5 a 10 dólares a tonelada, no final da década de 80 estes custos já atingiam 50 dólares, não sendo incomum taxas superiores a 100 dólares [RUCKELSHAUS, 1989].

Os resultados de um projeto (tanto produtos como efeitos) se estendem ao longo do tempo fazendo com seja necessário trazer a valor presente estes resultados de forma a ser possivel a comparação entre alternativas. Sabe-se que o valor de um consumo futuro tende a ser sempre menor do que o consumo atual. Este é o sentido de se empregar uma taxa de desconto positiva. Entretanto,a rentabilidade privada permite determinar o beneficio social somente no caso em que a taxa a empresa possa obter seus créditos seja a mesma que aquela que a sociedade deveria atualizar seu consumo futuro. $\mathrm{Na}$ realidade é duvidoso que haja coincidência entre estas duas taxas. A taxa de atualização social é quase sempre mais baixa do que a taxa privada ou individual, uma vez que, além do consumo futuro, o projeto gera desenvolvimento futuro e existe um sentimento de valorização das gerações futuras.

Desta forma, para a realização de uma análise econômica do projeto seria necessário, além dos custos e beneficios dos projetos alternativos à incineração, estimativas de taxas sociais e preços sombra para cada um dos fatores relacionados nominalmente na tabela abaixo. Para uma decisão correta estes fatores devem ser avaliados no período de seu impacto, trazidos a valor presente de fonma em que se possa 
calcular o Valor Presente Líquido do empreendimento. Na análise econômica o VPL deve ser necessariamente positivo para que um projeto seja econômicamente viável e a escolha entre as alternativas deve se basear na maximização deste valor presente. Assim:

$$
V P L=\sum_{j=0}^{N} \frac{B_{j}}{(1+i)^{j}}-\sum_{j=0}^{N} \frac{C_{j}}{(1+i)^{j}}
$$

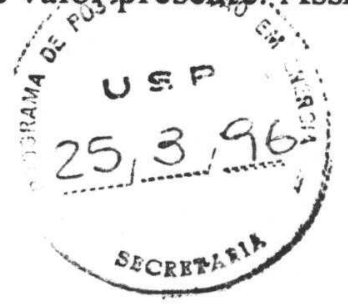

Tabela 6.16 - Custos e Beneficios de uma usina de incineração de RSU ${ }^{1}$

\begin{tabular}{l|l}
\hline \multicolumn{1}{c|}{ Custos } & \multicolumn{1}{c}{ Benefícios } \\
\hline - Impacto visual da usina & - Esterilização dos residuos \\
- Aumento da exposição da população a dioxinas & - Aumento da confiabilidade no fornecimento \\
(aumento casos câncer) & elétrico da região \\
- Aumento do tráfego de caminhões no entorno & - Diminuição do volume a ser aterrado: \\
da usina & ampliação da vida útil do aterro \\
- Emissão de metais pesados & - Reaproveitamento energético dos residuos \\
- Emissão de $\mathrm{CO}_{2}$ - efeito estufa & \\
- Emissão de $\mathrm{SOx}_{\text {e NOx }}$ & \\
- Risco de explosão & \\
\hline
\end{tabular}

1 outros custos e beneficios não considerados na análise financeira

Para auxílio na tomada de decisão pode ser elaborada ainda uma matriz de ordenamento de resultados conforme sugerido pelo ILPES (Instituto Latino de Planificación Economica y Social). Também aqui seria necessário o levantamento da mesma matriz para todas as alternativas de tratamento do RSU.

Tabela 6.17 - Matriz de ordenamento de resultados ILPES

\begin{tabular}{l|l}
\hline Elementos de rechaço & - Risco de contaminação por dioxinas e furanos \\
\hline Elementos limitantes de carater absoluto & $\begin{array}{l}\text { - Custo de Capital } \\
\text { - Custo de transporte }\end{array}$ \\
\hline Elementos limitantes de carater relativo & $\begin{array}{l}\text { - Custos dos processos alternativos de tratamento } \\
\text { - Poluição visual } \\
\text { - Poluição da água } \\
\text { - Poluição do ar (exceto contaminação por dioxinas e } \\
\text { furanos) } \\
\text { - Congestionamento das vias de acesso a usina }\end{array}$ \\
\hline Elementos condicionantes & $\begin{array}{l}\text { - Disponibilidade de terra para construção de aterro } \\
\text { sanitário } \\
\text { - Custo das tecnologias de tratamento alternativas } \\
\text { (reciclagem, compostagem, etc) }\end{array}$ \\
\hline
\end{tabular}


Conforme foi dito acima, a falta de dados impede a realização da análise econômica. Procurou-se levantar então os principais pontos que deveriam constar em uma análise deste tipo. Na verdade, deve ser empregada a mesma metodologia utilizada na análise financeira, apenas substituindo as taxas financeiras por taxas sociais e os preços de mercado por preços sombra. 


\section{Capítulo 7}

\section{Conclusões e Recomendações}

$\mathrm{O} A B C D$ é uma sub-região da RMSP que compreende 7 municípios e uma população de aproximadamente 2 milhões de habitantes. Esta região apresentou altos índices de crescimento populacional e urbanização nas últimas décadas. São coletados diariamente 1200 toneladas de resíduos sólidos na região das quais 170 toneladas não recebem destinação adequada. O restante é encaminhado para dois aterros e uma usina de compostagem localizados dentro dos próprios municípios da região. Estes dispositivos existentes encontram-se no final de sua vida útil. Desta forma, os municípios da região necessitam analisar as alternativas de acréscimo de sua capacidade de processamento e destinação dos resíduos.

Na verdade, a questão dos resíduos sólidos urbanos na região não é recente, datando da década de 70 os primeiros estudos visando a solução dos problemas então existentes. Durante estas duas décadas diversos estudos foram realizados mas poucas soluções foram efetivamente implantadas. Com a promulgação da lei que criava as Áreas de Proteção de Mananciais (APM) em 1976 estes municípios tiveram reduzidas as áreas disponíveis para implantação de dispositivos de tratamento e deposição de resíduos, uma vez que estas atividades são proibidas nestas áreas que representam $56 \%$ da área total da região. Após esta época foram construídas novas áreas de aterro apesar da dificuldade encontrada perante a população. Com o crescimento da mancha urbana, as áreas disponiveis para implantação sanitários praticamente se extingüiram, restando apenas alguns pontos com capacidade de deposição limitada.

Por outro lado. a tecnologia de incineração de RSU vem sendo empregada a mais de um século na Europa possibilitando uma melhor utilização dos depositórios finais 
existentes. Nos Estados Unidos. a escassez de área para construção de aterros aconteceu simultâneamente com o aumento das pressões ambientalistas na década 80 e a solução encontrada na época também foi a construção de incineradores. Existem diversos fabricantes com experiência comprovada e capazes de atender as normas de emissões mais restritivas.

Apesar das vantagens pregadas da incineração, o custo de capital de uma usina é alto e existem outros custos a serem considerados como riscos associados a emissões e ao próprio desempenho da usina. Para uma decisão definitiva sobre o problema é necessário:

- Realizar um estudo cuidadoso de caracterização dos resíduos gerados na região;

- Iniciar estudos de análise das alternativas visando a implantação de um programa de gerenciamento integrado de recursos;

- Prosseguir na integração regional através da ampliação das atribuições do Consórcio Intermunicipal do Grande ABC;

- Adequar as taxas de coleta e tratamento dos resíduos cobradas pelos municípios aos custos econômico-sociais realmente existentes.

- Realizar uma campanha de conscientização da população local da importância da questão dos resíduos sólidos urbanos e de esclarecimento quanto às alternativas de tratamento e disposição final disponíveis.

Estas medidas devem ser iniciadas o quanto antes dada a limitação de vida dos aterros existentes. Quanto a alternativa de incineração dos resíduos, concluiu-se que o empreendimento é tecnicamente viável, existindo tecnologias comercialmente comprovadas para implantação e, com base em cálculos aproximados estimou-se que seria possível a geração de $31 \mathrm{MW}$ queimando-se 1200 toneladas diárias de resíduos. A viabilidade financeira é comprometida pelo baixo poder calorífico do resíduo, pelo custo de capital e pelas condições de financiamento. A análise da projeção do fluxo de caixa mostrou que o valor presente liquido do empreendimento para taxas usualmente 
praticadas no mercado é negativo e a taxa interna de retorno obtida é significativamente baixa. Para taxas internas de retorno similares às de outras atividades da economia, o valor da taxa de incineração supera US\$100 por tonelada incinerada. Este valor é mais de cinco vezes maior do que o valor médio pago pelos municípios da região para destinação e tratamento dos RSU. É certo porém que os atuais valores não refletem os custos econômicos das soluções empregadas e taxas mais realistas de coleta e destinação de resíduos deverão ser cobradas pelas municipalidades. Não foi possível realizar uma análise econômica quantitativa, entretanto, dada a escassez de área na região, dada a perspectiva dos custos de programas extremamente agressivos de reciclagem, e o reduzido mercado de composto orgânico, acredita-se que as externalidades possam prover a viabilidade econômica do empreendimento.

É importante ressaltar que, independente de se buscar uma solução ou se realizar esta análise, o problema dos RSU na região do $\mathrm{ABCD}$ não deixarão de existir. Os custos de decisões tomadas em caráter de emergência são sempre maiores do que aqueles incorridos por soluções planejadas. Desta forma, a principal conclusão desta dissertação é que um estudo profundo da questão deve ser iniciado com aprovação no curto prazo de um plano de ações com comprometimento de todas as municipalidades. Dentro deste estudo, a incineração deve ser considerada como uma das alternativas ou componentes do sistema de gerenciamento integrado de resíduos. 


\section{ANEXO 1}

Dados os seguintes balanços de energia e de massa é possível se calcular o ciclo de vapor da usina em questão.:

\begin{tabular}{|c|c|c|c|c|c|}
\hline \multicolumn{2}{|l|}{ Balanço de N } & \multicolumn{3}{|c|}{ valores em $\mathrm{t} / \mathrm{h}$} & \\
\hline \multicolumn{2}{|l|}{ ENTRADA } & & \multicolumn{2}{|l|}{ SAIDA } & \\
\hline Resíduo & & \multirow[t]{4}{*}{50} & \multicolumn{2}{|c|}{ Gases Secos } & 106,96 \\
\hline Água & 25,00 & & $\mathrm{CO} 2$ & 25,87 & \\
\hline Voláteis & 16,75 & & N2 & 73,64 & \\
\hline Cinzas & 8,25 & & 02 & 7,45 & \\
\hline $\mathrm{Ar}$ & & \multirow{4}{*}{95,99} & Vapor de & gua & 32,12 \\
\hline $\mathrm{O} 2$ & 22,35 & & Resíduo & 25,00 & \\
\hline \multirow[t]{2}{*}{ N2 } & \multirow[t]{2}{*}{73,64} & & Queima & 5,78 & \\
\hline & & & Ar & 1,34 & \\
\hline \multirow[t]{2}{*}{ Umidade Ar } & & \multirow[t]{2}{*}{1,34} & & & \\
\hline & & & Cinzas & & 8,25 \\
\hline TOTAL & & 147,34 & TOTAL & & 147,34 \\
\hline
\end{tabular}

Balanço de Energia $(\mathrm{em} \mathrm{kJ} / \mathrm{h})$

\begin{tabular}{lc|lc}
\hline ENTRADA & & SAÍDA & \\
\hline Resíduo & 594070 & Vapor & 475256 \\
& & Cinzas & 3646 \\
& & Perdas & 11881 \\
& & Gases & 103286 \\
\hline Total & 594070 & & 594070 \\
\hline
\end{tabular}

Elaboração do autor.

O calor disponível na caldeira é utilizado para a geração de vapor e posterior extração desta energia em uma turbina. O ciclo mais utilizado é o ciclo de Rankine. A partir dos dados do lixo entrando na usina e alguns parâmetros de projeto realiza-se abaixo o cálculo do ciclo de vapor desta usina.

Assim: $\mathrm{kJ} / \mathrm{kg}$

$\mathrm{Q}=367721 \mathrm{MJ} / \mathrm{h} \quad$ assumindo $50 \mathrm{t} / \mathrm{h}$ de entrada de residuo com $\mathrm{PCI}=7354$

Segundo ---------- é possivel aproveitar até $80 \%$ do calor nos resíduos em uma caldeira moderna.

$$
\mathrm{Q}_{12}=294256 \mathrm{MJ} / \mathrm{h}=19.522 \mathrm{Mcal} / \mathrm{s}
$$


Pressão na saida da caldeira $\mathrm{P}_{2}=6205 \mathrm{kPa}=63.27 \mathrm{kgf} / \mathrm{cm}^{2}$ com temperatura de entrada $T_{1}=140 \mathrm{C}$ e temperatura de saída $T_{2}=443 \mathrm{C}$.

Das tabelas de líquido comprimido e vapor super-aquecido:

$\begin{array}{cccccc} & \mathrm{T}(\mathrm{C}) & \mathrm{p}\left(\mathrm{kgf} / \mathrm{cm}^{2}\right) & \mathrm{v}\left(\mathrm{m}^{3} / \mathrm{kg}\right) & \mathrm{h}(\mathrm{kcal} / \mathrm{kg}) & \mathrm{s} \mathrm{kcal} /(\mathrm{kg} . \mathrm{K}) \\ 1 & 140,0 & 63,27 & 0,0011 & 141,55 & 0,4136 \\ 2 & 443,0 & 63,27 & 0,0549 & 783,55 & 1,6001\end{array}$

Aplicando um volume de controle ao redor da caldeira obtem-se:

$$
\begin{gathered}
\mathrm{Q}_{12}=\mathrm{m} \cdot\left(\mathrm{h}_{2}-\mathrm{h}_{1}\right) \quad \text { (1a lei) } \\
\mathrm{m}=30.41 \mathrm{~kg} / \mathrm{s}
\end{gathered}
$$

Apicando agora um volume de controle sobre a turbina, considerando uma eficiência de $75 \%$ e uma pressão de saída de $1 \mathrm{kgf} / \mathrm{cm}^{2}$ :

$$
\mathrm{W}_{23}=\mathrm{m} \cdot\left(\mathrm{h}_{2}-\mathrm{h}_{3}\right) \quad\left(1^{\mathrm{a}} \text { lei }\right)
$$

Considerando o processo isoentrópico (adiabático reversível) pode-se determinar o ponto $3 \mathrm{~s}$.

$$
\begin{aligned}
& s_{2}=s_{3 s} \quad \text { (2a lei) } \\
& \begin{array}{ccccc}
\mathrm{T}(\mathrm{C}) & \mathrm{p}\left(\mathrm{kgf} / \mathrm{cm}^{2}\right) & \mathrm{v}\left(\mathrm{m}^{3} / \mathrm{kg}\right) & \mathrm{h}(\mathrm{kcal} / \mathrm{kg}) & \mathrm{s} \mathrm{kcal} /(\mathrm{kg} . \mathrm{K}) \\
99,1 & 1,00 & 1,5369 & 579,60 & 1,6001
\end{array} \\
& \text { Título: } x_{3 s}=89,09 \%
\end{aligned}
$$

Ainda da $2^{\mathrm{a}}$ lei:

$$
\begin{aligned}
& \eta_{t}=\frac{w_{t}}{\left(h_{2}-h_{3 s}\right)}=\frac{\left(h_{2}-h_{3}\right)}{\left(h_{2}-h_{3 s}\right)}=0,80 \\
& \begin{array}{cccccc} 
& \mathrm{T}(\mathrm{C}) & \mathrm{p}\left(\mathrm{kgf} / \mathrm{cm}^{2}\right) & \mathrm{v}\left(\mathrm{m}^{3} / \mathrm{kg}\right) & \mathrm{h}(\mathrm{kcal} / \mathrm{kg}) & \mathrm{s} \mathrm{kcal} /(\mathrm{kg} . \mathrm{K}) \\
& 99,1 & 1,00 & 1.6674 & 620,39 & 1,7098
\end{array}
\end{aligned}
$$

Título : $\mathrm{x}_{3}=96,7 \%$

Desta forma, na saída da turbina existirá uma mistura de vapor e condensado com $96,7 \%$ de vapor, valor este que não compromete o funcionamento da turbina. Qualquer ineficiência adicional viria a aumentar o título da mistura ou até mesmo atingindo $o$ ponto de vapor saturado.

A diferença de temperatura entre o condensado e a temperatura de fornecimento de água na caldeira é possibilitada pela inclusão de um regenerador entre o condensador e a caldeira. No regenerador é misturado vapor retirado a uma pressão intermediária na turbina com o líquido condensado. Esta configuração permite o aumento da temperatura na entrada da caldeira aumentando o rendimento global do ciclo. $\mathrm{Na}$ verdade o aumento 
da eficiência deve-se ao aumento da temperatura média de troca de calor o que compensa a perda pela não expansão da quantidade retirada na turbina. Assumindo-se um processo isobárico e desprezando quaisquer outras perdas, tem-se:

$$
\begin{gathered}
\mathrm{p}_{4}=\mathrm{p}_{6}=\mathrm{p}_{7} \\
\mathrm{~m}_{4} \cdot \mathrm{h}_{4}+\left(1-\mathrm{m}_{4}\right) \cdot \mathrm{h}_{6}=\mathrm{h}_{7} \quad\left(\mathrm{l}^{\mathrm{a}} \text { lei }\right)
\end{gathered}
$$

$\mathrm{O}$ ponto 7 pode ser determinado assumindo que o processo de bombeamento é isoentrópico e que o estado neste ponto é de líquido saturado. Logo:

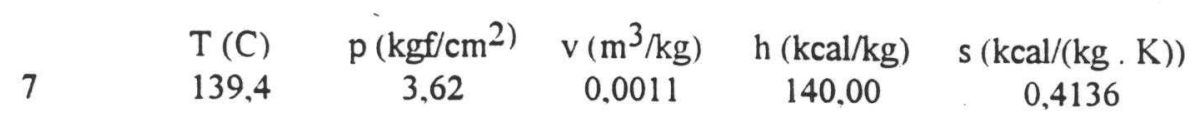

A partir do conhecimento da pressão de extração na turbina pode-se determinar o ponto 4. Da mesma forma que o ponto 3 supõe-se inicialmente um ponto $3 \mathrm{~s}$ que corresponde à expansão isoentrópica na turbina e, a partir da eficiência da turbina procede-se o cálculo do ponto 3 .

$$
\begin{array}{cccccc}
\multicolumn{9}{c}{\mathrm{s}_{2}=\mathrm{s}_{4 \mathrm{~s}}} & \text { (2 } \text { ( lei }) \\
\text { 4s } & \mathrm{T}(\mathrm{C}) & \mathrm{p}\left(\mathrm{kgf} / \mathrm{cm}^{2}\right) & \mathrm{v}\left(\mathrm{m}^{3} / \mathrm{kg}\right) & \mathrm{h}(\mathrm{kcal} / \mathrm{kg}) & \mathrm{s} \mathrm{kcal} /(\mathrm{kg} . \mathrm{K}) \\
& 139.4 & 3.62 & 0.4941 & 629.53 & 1,6001
\end{array}
$$

Título: $\mathrm{x}_{4 \mathrm{~s}}=95,6 \%$

Ainda da $2^{\text {a lei: }}$

$$
\begin{aligned}
& \eta_{t}=\frac{w_{t}}{\left(h_{2}-h_{4 s}\right)}=\frac{\left(h_{2}-h_{4}\right)}{\left(h_{2}-h_{4 s}\right)}=0,80 \\
& \begin{array}{cccccc} 
& \mathrm{T}(\mathrm{C}) & \mathrm{p}\left(\mathrm{kgf} / \mathrm{cm}^{2}\right) & \mathrm{v}\left(\mathrm{m}^{3} / \mathrm{kg}\right) & \mathrm{h}(\mathrm{kcal} / \mathrm{kg}) & \mathrm{s} \mathrm{kcal} /(\mathrm{kg} . \mathrm{K}) \\
4 & 167,8 & 3,62 & 0,5736 & 668,04 & 1,6938
\end{array}
\end{aligned}
$$

Analisando as tabelas de vapor percebe-se que o ponto 4 corresponde à região de vapor superaquecido. O ponto 5 , saida da água do condensador está à $p_{5}=1 \mathrm{kgf} / \mathrm{cm}^{2}$. As propriedades termodinâmicas neste ponto permitem calcular o ponto 6 de entrada do condensado no regenerador.

$$
\begin{gathered}
\mathrm{p}_{6}=\mathrm{p}_{7}=3,62 \mathrm{kgf} / \mathrm{cm}^{2} \\
\mathrm{~s}_{6}=\mathrm{s}_{5}\left(\eta_{\mathrm{b}}=100 \%\right) \\
\Delta \mathrm{h}=\mathrm{v} \Delta \mathrm{p} \\
h_{6}-h_{5}=\frac{v\left(p_{6}-p_{\mathrm{s}}\right) 10^{4}}{427}=0.0614
\end{gathered}
$$




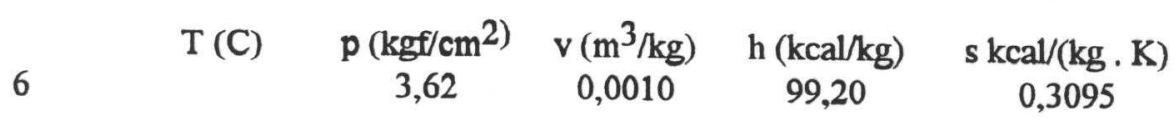

Com estes números é possível então calcular a fração de massa extraída para o regenerador.

$$
\begin{gathered}
\mathrm{m}_{4} 668,04+\left(1-\mathrm{m}_{4}\right) 99,2=140 \\
\mathrm{~m}_{4}=0,072 \mathrm{~kg} / \mathrm{kg}
\end{gathered}
$$

Como $\mathrm{m}=30,41 \mathrm{~kg} / \mathrm{s}$ :

$$
\mathrm{m}_{4}=2,18 \mathrm{~kg} / \mathrm{s}
$$

Energia entrando $Q_{12}=\left(h_{2}-h_{1}\right) m=19522 \mathrm{kcal} / \mathrm{s}$

Trabalho na turbina $\mathrm{W}_{\mathrm{t}}=\mathrm{m}\left[\left(\mathrm{h}_{2}-\mathrm{h}_{4}\right)+\left(1-\mathrm{m}_{4}\right)\left(\mathrm{h}_{4}-\mathrm{h}_{3}\right)\right]=4857,4 \mathrm{kcal} / \mathrm{s}$

Trabalho nas bombas $\mathrm{W}_{\mathrm{b}}=\mathrm{m}\left[\left(\mathrm{h}_{1}-\mathrm{h}_{7}\right)+\left(1-\mathrm{m}_{4}\right)\left(\mathrm{h}_{6}-\mathrm{h}_{5}\right)\right]=49,96 \mathrm{kcal} / \mathrm{s}$

Os valores calculados estão apresentados esquematicamente na figura abaixo:

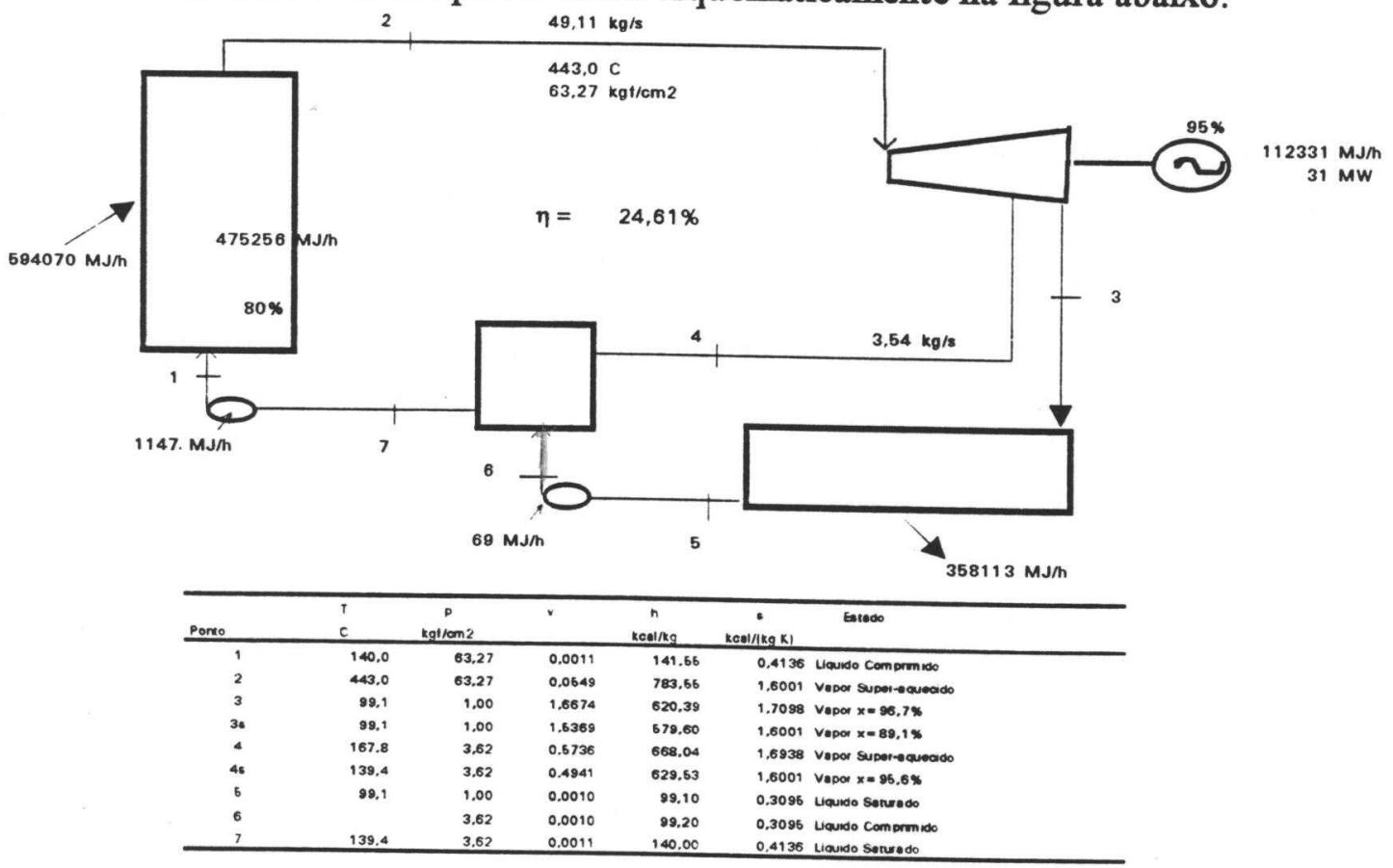




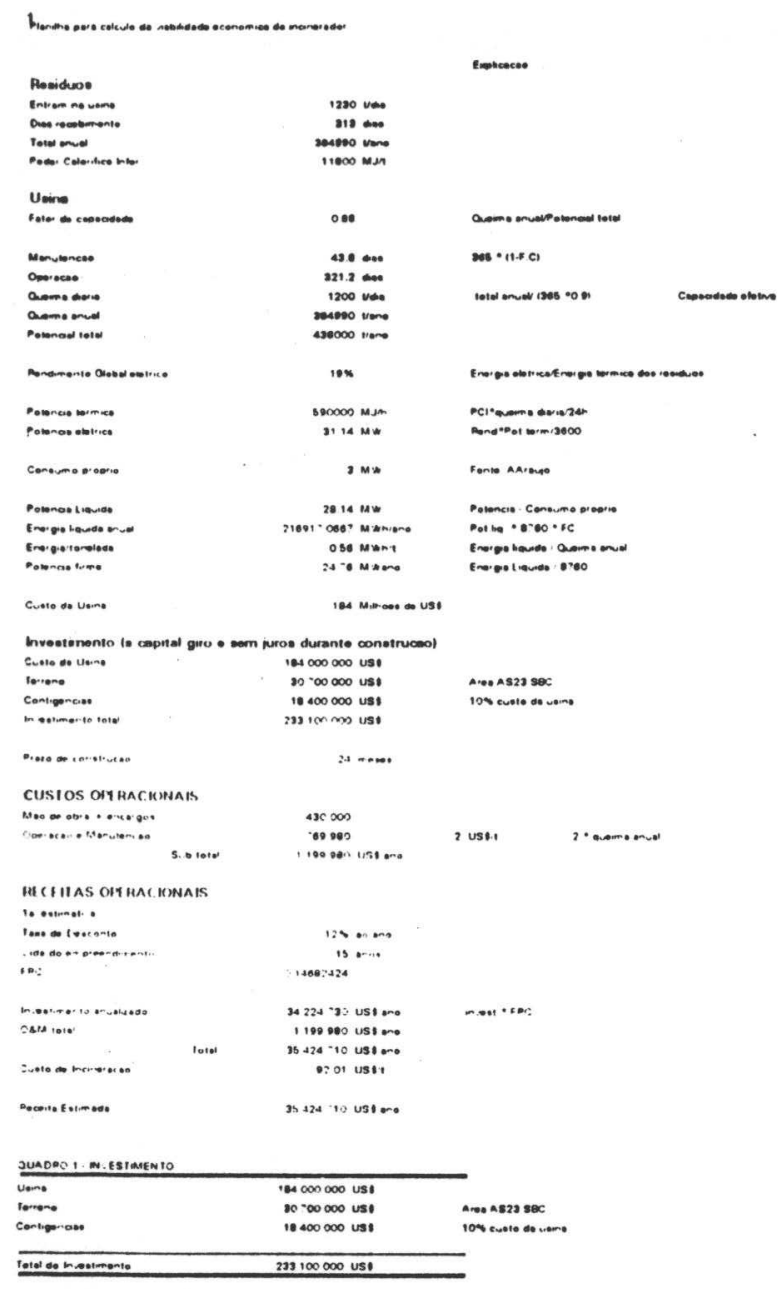

CRONOCRAMA DE RUESTMMENTOS DURANIE A MPIANIACAO

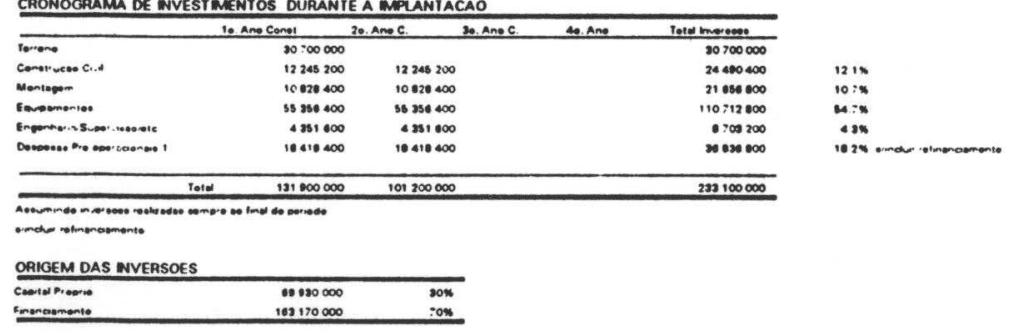

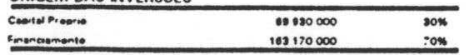

COMPOSKCAO DOS MUESTMENTOS

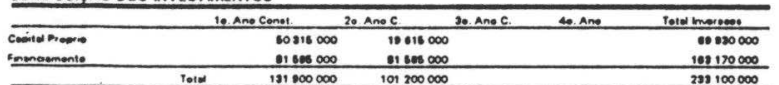




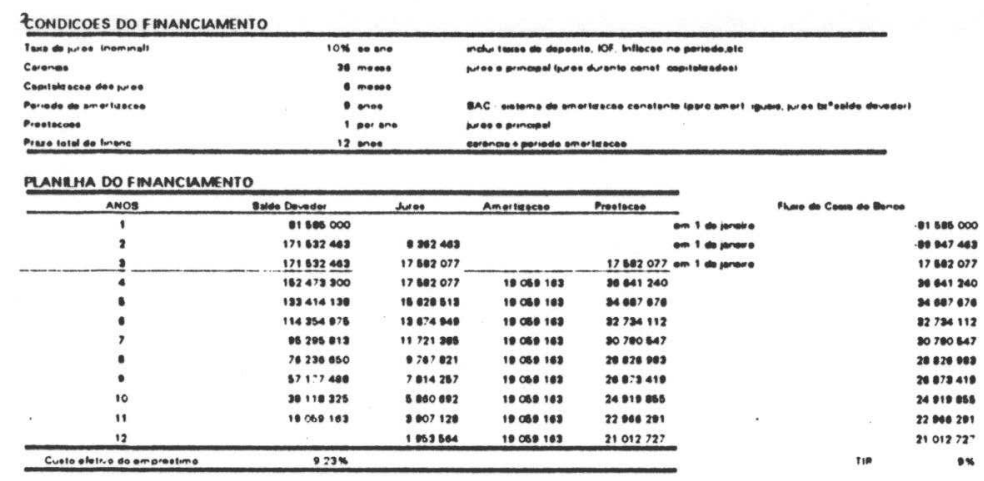

OUADRO DAS APICACOES DURANTE CONSTRUCAO
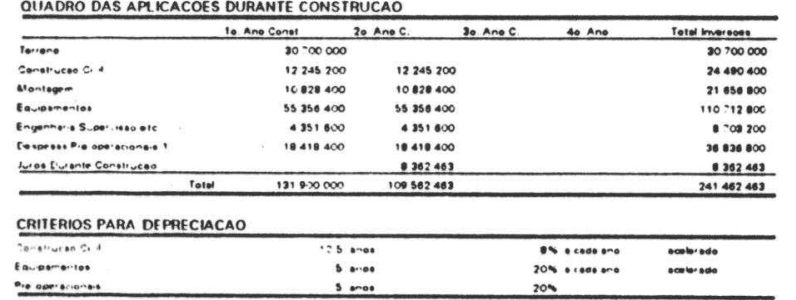

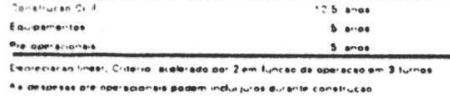

OUIADHO DE DEFTIFCIACAO

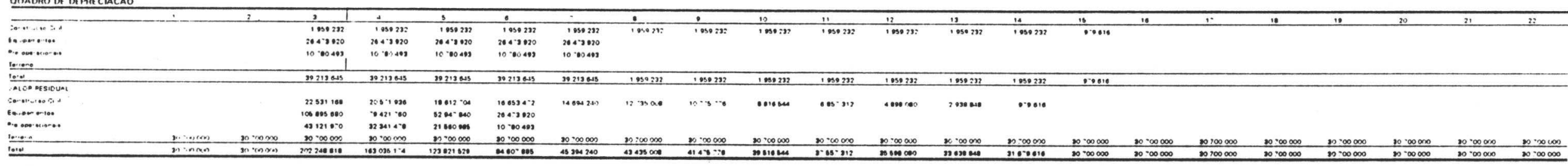

DE IERMINACAO DA TAXA DE NCMERACAO

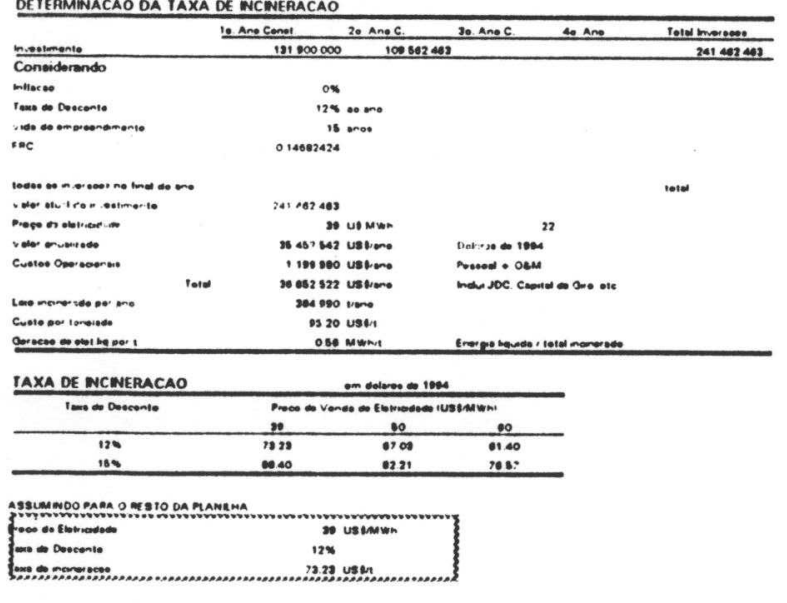

PROJECAO DOS RESULTADOS 


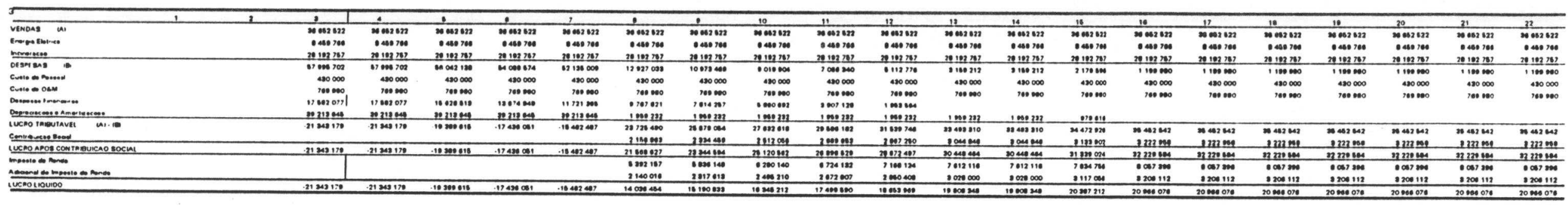

OUADRO DE FONIESE USO DOS RECURSOS

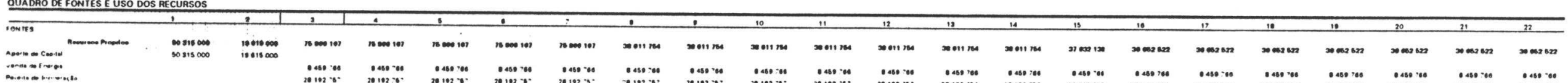

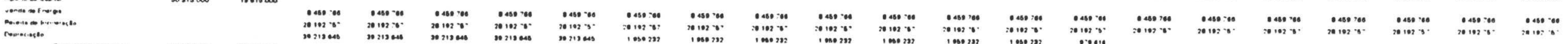

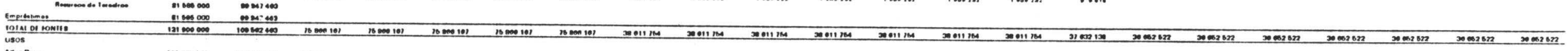

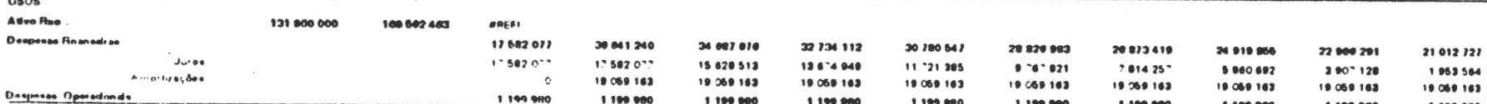

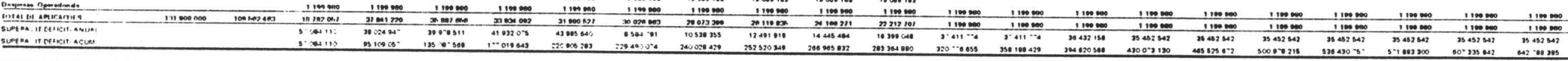
PROJFCAO DO FIUXO DE CAIXA

\begin{tabular}{|c|c|c|c|c|c|c|c|c|c|c|c|c|c|c|c|c|c|c|c|c|c|c|}
\hline 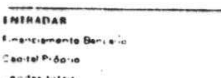 & 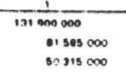 & 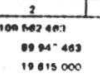 & $\frac{3}{\operatorname{mon}_{0,0,07}} 1$ & $\frac{1}{m \infty n m}$ & $=\frac{6}{m \rightarrow \infty, 20}$ & $\frac{1}{\operatorname{mos} 2528}$ & $\frac{1}{\sin m a n}$ & $\sin$ & $\frac{1}{x+m>n>1}$ & $\frac{10}{m \infty x \rightarrow m}$ & $\frac{11}{x m p * n}$ & $\frac{17}{3 \times \cos 6 m}$ & $\frac{13}{m e n c m n}$ & $\frac{14}{n \cos x n}$ & $\frac{18}{n=0 \times n}$ & $\frac{10}{x \cos 8 n}$ & $\frac{1 .}{x+5025 n}$ & $\frac{18}{306,28 n}$ & $\frac{10}{300,25 n}$ & $\frac{20}{300287}$ & $\frac{21}{30000}$ & $\frac{22}{300 \times 37}$ \\
\hline stons & 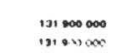 & 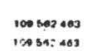 & 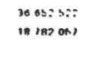 & 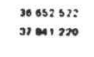 & 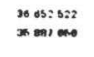 & $\begin{array}{l}3000325: 2 \\
3003000\end{array}$ & 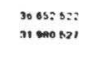 & 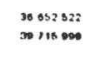 & 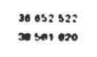 & 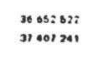 & 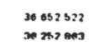 & 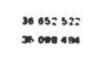 & 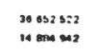 & 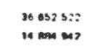 & 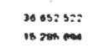 & 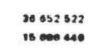 & 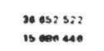 & 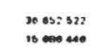 & 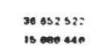 & 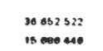 & 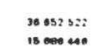 & 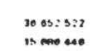 \\
\hline (1) & & & , & 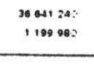 & 2006 & $\begin{array}{l}32.21112 \\
1,90000\end{array}$ & Nas & 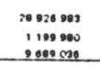 & 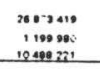 & 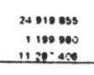 & 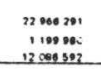 & 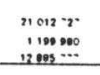 & 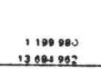 & 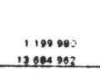 & 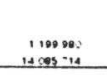 & 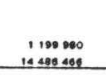 & 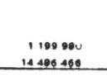 & 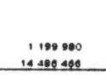 & 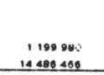 & 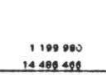 & 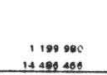 & 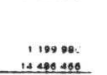 \\
\hline D.t. & & & Nenoeser & . & Imeme & 21100.91 & $.01100 \times$ & 30000011 & . $1000 \mathrm{om}$ & ma1. & onem & $\operatorname{cosenten}$ & n nereseo & 211001000 & $n=\infty$ & 2000000 & somone & somono & 2000000 & 0.0 & 20 resorere & nomonere \\
\hline 要, & 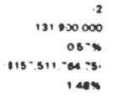 & $1005602+809$ & ר.e.sos & , 1000 os: & $\omega^{2} e^{2}$ & , as, & . & $2.80 . \therefore$ & 100000 & 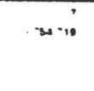 & 300000 & $\sin 60^{\circ}$ & 21.60 .00 & 2..." & 213008 & 200000. & 10 & 20000000 & 20000002 & 200000000 & 20006 & 10 \\
\hline ANALISE DO NVES I MME & 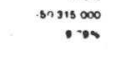 & 1001300 & $\cdots$ nass & 1 100. & ose- & 2.10039 & Concoss & , & .000000 & wo" & 30000 & 1.800000 & 210.000 & 20.500 & 21300000 & 2000000. & 20060000 & 200000000 & 200800002 & 2008000000 & $20900 \mathrm{crs}$ & 3100000. \\
\hline
\end{tabular}




\section{REFERÊNCIAS BIBLIOGRÁFICAS}

AMERICAN REF-FUEL, "The 'Cone:' Minimizing the Risk of Fluctuating Energy Rates". Catálogo da empresa. 1986.

ATKINS, Gerald. Integrating material and energy recycling. Wastes Management. Set. 1993. pp. 30-32.

BAILEY. Jeff. "Falta lixo para os incineradores". Gazeta Mercantil, 25 de agosto de 1993. Meio Ambiente, pag. 13.

BERLINCIONI, Moreno: Di Domenico, Alessandro. "Polychlorodibenzo-p-dioxins and Polychlorodibenzofurans in the soil near the Municipal Incinerator of Florence, Italy." Environ. Sci. Technol. Vol.21, No.11. 1987 pp.1063-1069.

BICKERSTAFFE, Jane. Waste minimisations in the realm of packaging. Waste Management, Mar., 1994. pp.23-24.

BJELDANES, M.N., KRIESKY. L.J., RIEBLING, W.E.. Resource recovery highlights retrofit of abandoned plant. Power. v.33,n.4,p.S61-S64,Apr 1989.

BOUILLE, Daniel Hugo. Evaluacion de Proyectos. Instituto de Economia de Energia. San Carlos de Bariloche. Set. 1985. Apostila do XV Curso Latinoamericano de Economia y Planificacion Energetica.

BRETZ, Elizabeth(Ed.). Energy from wastes. Power. v.34,n.3,p.S1-S10,Mar 1990.

BRETZ, Elizabeth(Ed.). Energy from Wastes. Power. v.33,n.3,p.W1-W26,Mar 1989.

BRIDGES, James S.: Curran. Mary Ann. Life Cycle Assessment for Municipal Solid Waste Management. In: International directory of solid waste management: The ISWA Yearbook 1993/94. Copenhagen, ISWA, 1994. pp.15-19.

BRNA. Theodore G.; Kilgroe. James D.. "The Impact of Particulate Emissions Control On the Control of Other MWC Air Emissions". J Air Waste Manage. Assoc. Vol.40, No.9 Set. 1990. pp. 1324 - 1330.

BRUINS, R.J.F. et al. Assessing Potential Health Effects from Municipal Sludge Incinerators. JAPCA. v.37.n.4,p.395-399,Apr 1987.

BRUNNER, Calvin R. Handbook of Incineration Systems. New York:McGraw Hill, 1991.

BRUNNER, P.H.. Approche Globale des Problémes d'environnement lies à l'incinération D'ordures Ménagéres. Pollıtion Atmosphérique. p.301-308,Jul.Sep 1988.

BYARD, J.L. J.Toxicol.Environ.Health 22:381-403 (1987) 
CHAPPEL. Peter. "A Review of Municipal Waste Combustion Technology" in: Energy From Waste : Clean, Green \& Profitable. Seminário do Institute of Energy. Londres, 9 out. 1991.

COLLINS, Steve (ed). Factor 10 years of experience into new landfill-gas powerplants. Power, Jul. 1990. pp. 61-64.

COLLINS, Steve. Utilities seek to help ease solid-waste disposal crisis. Power. v.35,n.8, p.42-47,Aug 1991.

COLLINS,Steve(Ed.). Mass-burn plant solves Long Island Community's waste-disposal problems. Power. v.35,n.1,p.60-61,Jan 1991.

COVELLO, Vicent T.. Communicating Right-to-know Information on Chemical Risks. Environ. Sci. Techn. v.23,n.12,p.1444-1449,Dec 1989.

Dept. of Transp. Emergency Response Guidebook 1987. Washington. DC: US Govern. Printing Off., 1987, p.G26

DHHS/ATSDR; Toxicological Profile for 2,3,7,8 Tetrachlorodibenzo-p-dioxin. ATSDR/TP-88/23 (1988)

DOUGHERTY, Ralph C., COLLAZO-LOPEZ, Humberto. Reduction of Organochlorine Emissions from Municipal Waste Incinerators. Environ. Sci. Techn. v.21,n.6,p.602-604,Jun

DOWD, Richard M.. "EPA revisits dioxin risks". Environ. Sci. Technol.. Vol.22, No.4, 1988 pp373.

DOWD, Richard M.. EPA Revisits Dioxins Risks. Environ. Sci. Technol.. v.22,n.4,p.373,Apr 1988.

ELTZER, Brian D., HITES, Ronald A.. Atmospheric Transport and Decomposition of Polychlorinated Dibenzo-p-dioxins and Polychlorinated Dibenzofurans. Environ. Sci.Techn. v.23,n.11,p.1396-1401,Nov 1989.

ERICSON, Mitchell D. et al.. "Polychlorinated Dibenzofurans and Other Thermal Combustion Products from Dielectric Fluids Containing Polychlorinated Biphenyls". Environ. Sci. Tech., 1989, Vol. 23, No.4, pp.462-470

FAGA, Francisca S.. Sem coleta seletiva de lixo, composto produzido em São Paulo contém impurezas. Gazeta Mercantil, 1 abr. 1993, Meio Ambiente.

FUICA, Luis. Boost power output from MSW plants with fired superheater. Power. v.34,n.2, p.69,Feb 1990.

GIBBS. D.R., Blue, J.D., Hepp, M.P.. "Design and Operating Experience with high Temperature and High Pressure Refuse-fired Boilers". trabalho apresentado no ASME Waste Processing Conference, Philadelphia, May 1-4, 1993. 
GIBBS, David R., Hepp, Mark P.. "Mass-burn plant achieves high availability, low emissions". Power, Abr. 1990.

GUNN, David; Horton, Robert. Industrial Boilers. Longman Sci. Tech., Essex, Inglaterra, 1989. pag.51

HAGENMALER, Hanspaul; Kraft, Michael; Brunner, Herman; Haag, Roland.

"Catalytic Effects of Flyash from Waste Incineration Facilities on the Formation and Decomposition of Polychlorinated Dibenzo-p-dioxins and Polychlorinated Dibenzofurans". Environ. Sci. Technol., Vol.21, No.11, 1987. pp. 1080-1084. (a)

HAGENMALER, Hanspaul; Kraft, Michael; Brunner, Herman; Haag, Roland. "CopperCatalyzed Dechlorination/Hydrogenation of Polychlorinated Dibenzo-p-dioxins, Polychlorinated Dibenzofurans, and Other Chlorinated Aromatic Compounds". Environ. Sci. Technol., Vol.21, No.11, 1987.pp. 1085-1088. (b)

HAY, A.. Nature. London, 278 (5700):108-9 (1979)

HICKMAN, H.Lanier; Reimers, Eric G.. "Unit Pricing for Muncipal Solid Waste Management Services". INTERNATIONAL Directory of Solid Waste Management: the ISWA Yearbook 1993/4, Copenhagen, 1994.

HOFFMAN, Robert V. et al. Mechanism of Chlorination of Aromatic Compounds Adsorbed on the Surface of Fly Ash from Municipal Incinerators. Environ. Sci. Techn.v.24,n.11,p.1635-1641,Nov 1990.

IARC. Monographs on the Evaluation of the Carcinogenic Risk of Chemicals to Man. Geneva, WHO, International Agency for Research on Cancer, 1972 - , V15. (1977)

INTERNATIONAL Directory of Solid Waste Management: the ISWA Yearbook 1993/94. Copenhagen, ISWA, 1994.

JOCHUM, Joachim; Jodeit, Harald; Wieckert, Christian. "Glassification and commercial utilization of filter ash". ABB Review. No.3, 1991. pp. 29-34.

JOHNSTON, Michael G., Stevenson, Walter H.. "Overview of Proposed Air Emission Standards and Guidelines for Municipal Waste Combustors". J.Air Waste Manage. Assoc.. Vol.40, No.6, Jun 1990. pp.932-935.

JORDAN, Richard J.. Treating Wate-to-Energy Flue Gas. JAPCA. v.37,n.4,p.422-430, Apr 1987.

JORMANAINEN, Martti. Biothermal and Wabio- Advantages in the treatment of MSW and Sludge. In: International directory of solid waste management: The ISWA Yearbook 1993/94. Copenhagen, ISWA, 1994. pp.121-124.

JUNGMANN, Günter. "Pollutant emissions reduced by retrofitting waste incineration plants" . ABB Review. 2/93. pp 15-20. 
KATARI, Vishnu, YATAVUK, Willian M., WEHE, Albert H.. Incineration Techniques for Control of Volatile Organic Compound Emissins. JAPCA. v.37,n.1,p.91<9 9 fant 1987.

KINLIN,T.E. et al. J.Agric. Food Chem. 20:1021 (1972).

KIRK-OTHMER CONDENSED ENCYC. CHEM. TECH. 1985, p.543

KNOWLES, Mike. "Energy from Waste Plants for the 1990s". Waste Management. Jan., 1993. pp.23-26.

KORZUN, Edwin A., HECK, Howell H.. Sources and Fates of Lead and Cadmium in Municipal Solid Waste. J.Air Waste Maneg. Assoc.. v.40,n.9,p.1220-1226,Sep 1990.

KRAUSE, Gilson G., Poppe, Marcelo K.. "Les perspectives de développment de la production d'électricité indépendente des concessionnaires". CIRED, Paris, Nov. 1994. (pre-print)

LAKIND, Judy, RIFKIN, Erik. Current Method for Setting Dioxin Limits in Water Requires Reexamination. Environ. Sci. Techn. v.24,n.7,p.963-965,Jul 1990.

LEVIN, Arlene et al.. "Comparative Analysis of Health Risk Assessments for Municipal Waste Combustors". J.Air Waste Managem.Assoc., Vol.41, No.1, Jan. 1991, pp.20-31.

MAKANSI, Jason (ed). "Traditional control processes handle new pollutants". Power, Out. 1987. pp.11-18.

MAKANSI, Jason (ed.). "Boilers, combustion systems and their auxiliaries". Power. Vol.136, No.6. pp.51-102.

MAKANSI, Jason(Ed.). Co-combustion turns waste liability into energy asset. Power v.30,n.10,p.97-99,Oct 1986.

MAKANSI, Jason(Ed.). RDF-fired plant design reflects lessons learned. Power. v.33,n.8,p.67-69,Aug 1989.

MARINI, Patricia. Lixo: Uma Montanha de Problemas. Dirigente Municipal, Vol. 23, No.3, mar 1992.

MOSES, M. et al., Am. J. Ind. Med., 5 (3):161-82, 1984

NOLAN, R.J. et al.. Tocixol. Appl. Pharmacol., 48 (1):A162 1979

NYSTRÖM, K.L.E.. "Incineration Waste and the Greenhouse Effect". ISWA Times, No.2, 1993.

PARR, J.F., Marsh, P.B.. Kla, J.M. (eds) Land Treatment of Hazardous Wastes. Park Ridge, NJ,: Noyes Data Corp. 1983 
PENNER, S.S. et al. Waste Incineration and Energy Recovery. Energy, Vol.13, No.12, 1988. pp.845-851.

PHUONG, N.T.N. et al. Chemosphere, 19 (1-6):933-6 (1989)

PORTEOUS, Andrew. "Prospects for Municipal solid Waste Incineration". Wastes Management Proceedings, October 1992. pp.21-27.

POWER. Clean Act Amendments-Managing solid waste. v.35,n.6,p.48-53,Jun 1991.

POWER. Semass aims for 'total recovery' of all resources. v.33,n.10,p.S28-S32, Oct 1989.

POWER. Energy from waste: On-site heat-recovery incineration. v.31,n.3,p.W1-W16,

REASON, John. 50-MW steam powerplant burns landfill gas. Power. v.31,n.2,p.6263,Feb 1987.

REASON, John. Next step for waste-to-energy: better availability, efficiency. Power. v.30,n.7,p.17-24,Jul 1986.

ROSE, J.Q. et al.. Tocixol. Appl. Pharmacol., 36 (2):209- 26, 1976

RUCKELSHAUS, William. "The Politics of Waste". Discurso proferido na National Conference of State Legislators, s.1., 10 Ago. 1989.

s.a., "Slay the WTE plant dragon: boiler tube wastage". Power, Out. 1992. pp. 42- 44.

SAROFIM, Adel F., "Thermal Processing: Incineration and Pirolysis", in: WILSON, David G. (ed.), Handbook of Solid Waste Management, Van Nostrand, New York, 1977. pp 166-196.

SERRA, Neuza. Comgas planeja implantação de usina de incineração de lixo domiciliar. Gazeta Mercantil, São Paulo, 30 setembro 1992.)

SHANTZ, S.L., Bowman, R.E.. Neurotoxicol. Teratol. 11(1):13-9 (1989)

SIMON, Manfred. "The road to environmentally compatible power and heat generation". ABB Review. 1991, No. 3. pp.3-12.

SMITH, Larry A., SIMS, Howard C.. NJ's Largest WTE Facility Nears Commercial Operation. Power, v.35,n.4,p.65-70,Apr 1990.

STEVEN, Bernard J., New Approaches to Municipal Solid Waste Management, Massachusetts Institute of Technology, Boston, June 1989, Master Thesis

STEVENS, Jeffrey B, SWACKHAMER, Deborah L.. Environmental Pollution: A multimedia approach to modeling human exposure. Environ. Scl Techn. v.23,n.10,p.1180-1185,Oct 1989. 
STOHS, S.J.. Free Radio. Biol. Med.. 9 (1):79-90 1990

TAKACS, Laszlo; McQueen, Ann; Moikanen, George L.. "Development of the Ammonia Injection Technology (AIT) for the Control of PCDD/PCDF and Acid Gases from Municipal Solid Wastes Incinerators". Air \& Waste. Vol.43, Jun. 1993. pp.889-897.

TAYLOR, Philip H., Dellinger, Barry, Lee, C.C.. "Developmnent of a Thermal Stability Based Ranking of Hazardous Organic Compound Incinerability", Environ. Sci. Tech., 1990, Vol. 24, No.3, pp.316-328.

TECHNOPLAN, Incineração de Resíduos Sólidos Urbanos, São Paulo, Março 1991. Relatório Interno.

TRAVIS, Curtis C., Hattemer-Frey, Holly A., Silbergeld, Ellen. "Dioxin, dioxin everywhere". Environ. Sci. Technol., Vol.23, No.9, 1989. pp.1061-1063.

U.S. EPA. EXAMS II Computer Modeling Simulation, 1987

United Nations, Treatment and Disposal Methods for Waste Chemicals. Data Profile Series No.5. Geneva, Switzerland, UNEP, Dec. 1985.

USEPA, Methodology for Evaluating Potential Carcinogenicity in Support of Reportable Quantity Adjustments Pursuant to Cercla Section 102 (Final) USEPA, 1988 (EPA 1600/8-89/053)

VISALI, Joseph R. A Comparison of Dioxin, Furan and Combustion Gas Data from Test Programs at Three MSW Incinerators. JAPCA. v.37,n.12,p.1451-1463, Dec 1987.

VISALLI, Joseph R. "Hazardous Waste Management - A Comparison of Dioxin, Furan, and Combustion Gas Data from Test Programs at Three MSW Incinerators". JAPCA, Vol. 37, No.12, 1987, pp.1451-1463.

WEBER, H. et al., Xenobiotica 12 (6): 353-7 (1982) 